\title{
Provas de Carga Dinâmica em Estacas Escavadas de Pequeno Diâmetro com Ponta Modificada
}

Carlos José Marques da Costa Branco

Tese apresentada à Escola de Engenharia de São Carlos da Universidade de São Paulo, como parte dos requisitos para a obtenção do título de Doutor em Engenharia - Área Geotecnia.

ORIENTADOR: Prof. Dr. José Carlos A. Cintra 


\section{FOLHA DE APROVAÇÃO}

\section{Autor:}

Título:

Tese defendida e aprovada em pela comissão julgadora:

(Assinatura)

(Nome / Instituição)

(Assinatura)

(Nome / Instituição)

(Assinatura)

(Nome / Instituição)

(Assinatura)

(Nome / Instituição)

(Assinatura)

(Nome / Instituição)

Coordenador da Área 
The necessity is the mother of invention.

Francesco Zappa 


\section{DEDICATÓRIA}

Às minhas queridas Helenida, Natália e Renata, pelo apoio e paciência

À memória de meu pai, Carlos da Costa Branco, pelo exemplo.

E, sobretudo, ao Pai, pela oportunidade da vida. 


\section{AGRADECIMENTOS}

Ao Professor Dr. José Carlos A. Cintra, pelo apoio, confiança irrestrita e orientação

Ao Professor Dr. Nelson Aoki, pela amizade, apoio e sugestões

Ao Professor Dr. Orêncio Monje Villar, pelo apoio e sugestões

Aos amigos Antônio Belincanta, Fabrício Augusto Vicente, Jeselay Hemetério Cordeiro dos

Reis, Luiz Russo Neto, Mauri Gotlieb, Miriam Gonçalves Miguel, Nelci Helena Maia

Gutierrez, Patrik Vessaro, Pedro Elísio C. A. F. da Silva, Raquel Souza Teixeira, todos os professores e os colegas de turma da EESC, pela amizade e troca de informações

Aos funcionários José Luís Guerra (EESC) e Pedro Cândido de Souza (UEL), pelo apoio com os ensaios de laboratório

Às Universidade Estadual de Londrina, Escola de Engenharia de São Carlos/USP e

Universidade Estadual de Maringá, pelo apoio com laboratórios, equipamentos e serviços

À CAPES, pelo fomento da bolsa

Às empresas In Situ, Basestac e Constroeste, pelo indispensável auxílio com os experimentos

À minha mãe, pela força incondicional e o brilho dos seus 80 anos

Aos meus familiares e aos meus amigos

A todos,

Meu sincero muito obrigado! 


\section{RESUMO}

Fundações por estacas escavadas com trado mecânico têm sido largamente empregadas para cargas de pequeno e médio porte. Como o processo executivo não consegue evitar a deterioração das propriedades do solo in situ no fundo da escavação, a única parcela confiável de resistência é aquela referente ao atrito lateral. No entanto, a ponta dessas estacas, muitas vezes, atinge estratos com resistência relativamente elevada e não consegue aproveitar as qualidades do estrato. O presente trabalho visou o estudo do comportamento desse tipo de estaca no perfil geotécnico típico da cidade de Londrina, através da execução de provas de carga dinâmica em 16 estacas de $0,25 \mathrm{~m}$ de diâmetro e $12 \mathrm{~m}$ de comprimento, sendo três estacas tradicionais e 13 estacas com ponta modificada. Foram feitas, também, provas de carga estática em duas estacas tradicionais, inspeção das pontas de todas as estacas e determinação dos parâmetros de resistência do solo. Os resultados mostraram que todas as modificações pesquisadas permitiram a utilização da carga estrutural nominal das estacas e que a mais eficiente foi a do tipo que promoveu a melhoria do solo na ponta com a adição de um estabilizante de solo.

Palavras-chave: fundações, colapsibilidade, ponta modificada. 


\section{ABSTRACT}

Auger pile foundations have been widely employed for light to medium loads. As the executive process can't avoid the degradation of the bottom excavation "in situ" soil properties, the only reliable resistance is a lateral friction parcel. However, these tip piles, many times, reaches relatively resistant strata and can't take advantage from these strata qualities. The present paper seems study the performance of this kind of piles in typical geotechnical profile of Londrina, by dynamic load tests on 16 piles with diameter equal 0,25 $\mathrm{m}$ and length of $12 \mathrm{~m}$, when three traditional piles and on thirteen kinds with tip modification. Were made, also, static load tests on three traditional piles, tip investigation on all piles and soil resistance parameters determination. The results shaw that all modifications researched was able to use the nominal structural load of piles and that the more efficient of them was the soil improvement by soil stabilizer addition.

Key-words: foundations, colapsibility, modified tip. 


\section{LISTA DE FIGURAS}

Figura 2.1 - Diferentes tipos de ensaios em estacas (HOLEYMAN, 1997)

8

Figura 2.2 - Curva carga versus recalque - ensaio de carregamento estático (AOKI, 1997) ...

Figura 2.3 - Superfícies de ruptura de estacas segundo diversos autores (VESIC', apud CINTRA; AOKI, 1999)

Figura 2.4 - Fator de capacidade de carga $\mathrm{N}_{\mathrm{q}}{ }^{*}$ para diversos mecanismos de ruptura de estacas (VESIC', apud CINTRA; AOKI, 1999)

Figura 2.5 - Efeito de embutimento (De BEER, apud SILVA, 2001)..... 18

Figura 2.6 - Padrão assumido de ruptura na ponta (VESIC', 1975) 20

Figura 2.7 - Padrões de ruptura (VESIC', 1975)... 21

Figura 2.8 - Expansão de cavidade esférica (VESIC, apud SILVA, 2001) ..... 22

Figura 2.9 - Zonas devidas à expansão de cavidade em ensaios de cone em câmara de calibração (SALGADO et al., 1997) .............................................24

Figura 2.10 - Deformação da malha em argilas saturadas (BALIGH, 1985) .... 25

Figura 2.11 - Trajetórias de deformação na penetração de uma estaca (BALIGH, 1985)

Figura 2.12 - Ocorrência de colapso de um solo sob tensão e com inundação artificial (CINTRA, 1998)

Figura 2.13 - Função de transferência das solicitações em um elemento isolado de fundação (apud VESIC, 1975).

Figura 2.14 - Modelo mais elaborado da função de transferência das parcelas de atrito lateral e resistência de ponta

Figura 2.15 - Deslocamentos devidos às parcelas de atrito lateral e resistência de ponta

Figura 2.16 - Curvas carga versus recalques de uma estaca instrumentada (Van WEELE, 1957).

Figura 2.17 - Modelo de Smith para a curva atrito lateral versus deslocamento no ensaio de carregamento dinâmico (apud AOKI, 1997).

Figura 2.18 - Modelo de Smith (1960) para a curva resistência de ponta versus deslocamento no ensaio de carregamento dinâmico (apud AOKI, 1997) 35 
Figura 2.19 - Parâmetros que afetam o comportamento de estacas em areias (KRAFT JR., 1991)

Figura 2.20 - Efeito da instalação (Van WEELE, 1988, apud De BEER, 1988) 37

FIGURA 2.21 - Tipos de parafusamento (Van IMPE; PEIFFER, 1997). 38

Figura 2.22 - Alguns tipos de ponta (Van IMPE; PEIFFER, 1997 e BUSTAMANTE; GIANESELLI, 1998)

Figura 2.23 - Efeitos da execução no estado de tensões do solo e sua influência no comportamento de estacas (VESIC', 1975)

Figura 2.24 - Estacas Strauss - Vista geral e detalhe. 47

Figura 2.25 - Estacas Franki (ABEF, 1999) ................................................. 50

Figura 2.26 - Estacas escavadas com trado mecânico .......................................52

Figura 2.27 - Tipos de ferramentas para estacões (CASAGRANDE, 1999) ...............53

Figura 2.28 - Tipos de ferramentas para estacas Barrete (CASAGRANDE, 1999)......54

Figura 2.29 - Execução de estacões (BAUER, 1997; particular, 1999).....................56

Figura 2.30 - Equipamentos para execução de estacas Barrete (CASAGRANDE,

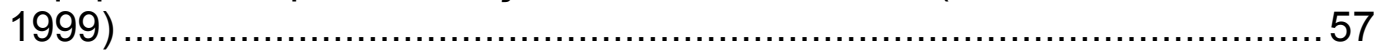

Figura 2.31 - Exemplo de equipamento para a execução de estacas raiz e micro estacas (BERETTA, 1999)

Figura 2.32 - Execução de estacas raiz (TAROZZO; GRANDIS, 2000). 60

Figura 2.33 - Efeitos da injeção nos solos (SALIONI, apud SODRÉ, 1996). 61

Figura 2.34 - Execução de estacas CFA (BAUER, 1997) 63

Figura 2.35 - Execução de estacas Ômega (BOTTIAU et al., 1998). 66

Figura 2.36 - Execução de estaca Ômega+ (BOTTIAU et al., 1998) 67

Figura 2.37 - Ferramentas utilizadas para o alargamento da base (TOMLINSON, 1997)

Figura 2.38 - Perfil do terreno e resultado de prova de carga em um tubulão antes e depois do grauteamento (COSTA NUNES, 1992)......

Figura 2.39 - Sistema Bauer de grauteamento (BAUER, 1997) .......................... 70

Figura 2.40 - Execução de injeção de resina química (RODRIGUES, 1998) ...............71

Figura 2.41 - Execução de apiloamento da ponta 
Figura 2.42 - Execução de sistema de expulsão de plug (MASSARSCH et al., 1988) .74

Figura 2.43 - Método SENTAN de compactação da base (KONDOU et al., 1998) .......75

Figura 2.44 - Estacas Soilex (SELLGREN et al., 1985; BROMS, 1985)................... 76

Figura 2.45 - Célula de pré-carga (BOLOGNESI; MORETTO, 1973) ........................77

Figura 2.46 - Célula de pré-carga (LIZZI, 1976 e 1988) ....................................... 78

Figura 2.47 - Sistema BAUER de grauteamento da base (YEATS; RIORDAN, 1989). 80

Figura 2.48 - Expancell - Vista geral do sistema e detalhe da célula 81

Figura 2.49 - Detalhe do gradiente hidráulico 81

Figura 3.1 - Mapa de Londrina e a localização do CEEG 84

Figura 3.2 - Área do CEEG com a locação das campanhas de investigação do subsolo e das áreas de pesquisas

Figura 3.3 - Execução dos furos SP3 (frente) e SP9 (fundo) 87

Figura 3.4 - Perfil (W-E) obtido na sondagem de simples reconhecimento com SPT ...88 Figura 3.5 - Perfil (S-N) obtido na sondagem de simples reconhecimento com SPT ....89

Figura 3.6 - Resultados dos SPTs 90

Figura 3.7 - Coleta de amostra indeformada (P14) .......................................... 91

Figura 3.8 - Argila siltosa porosa característica do $1^{\circ}$ estrato (P14)....................... 92

Figura 3.9 - Argila siltosa residual característica do $3^{\circ}$ estrato (P9) ......................... 92

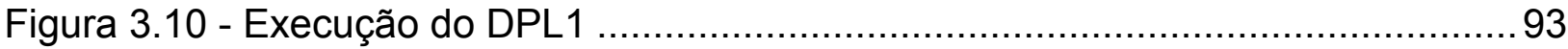

Figura 3.11 - Resultados dos DPLs............................................................... 93

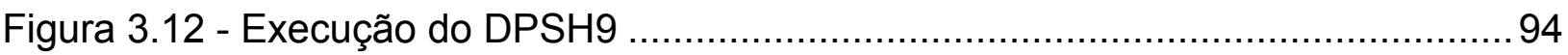

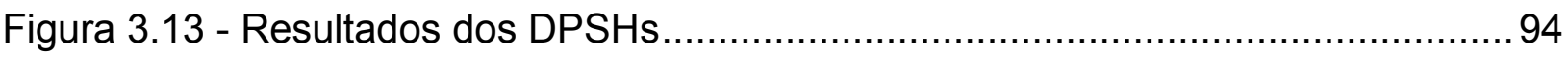

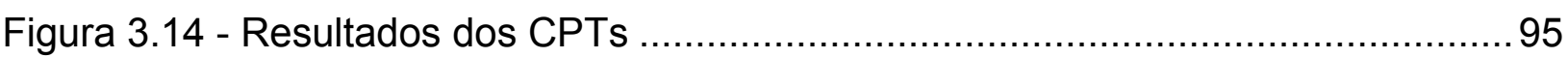

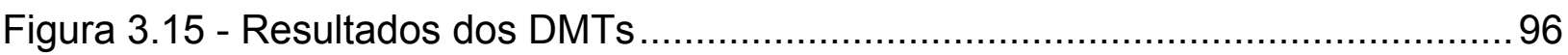

Figura 3.16 - Resultado do ensaio de permeabilidade in situ..............................96

Figura 3.17 - Curvas granulométricas com e sem defloculante (amostras até $6 \mathrm{~m}$ ).......99

Figura 3.18 - Índice de subsidência do estrato superficial................................ 101

Figura 3.19 - Aparelho de Richards .......................................................... 102 
Figura 3.20 - Detalhe das amostras de solo sobre a pedra porosa 102

Figura 3.21 - Curvas características de sucção médias (profundidades de 4 m e 6 $\mathrm{m})$.

Figura 3.22 - Curvas características de sucção transformadas (profundidades de $4 \mathrm{~m}$ e $6 \mathrm{~m})$.

Figura 4.1 - Vista geral da perfuratriz 107

Figura 4.2 - Detalhe da perfuratriz e do trado 107

Figura 4.3 - Discos de isopor. 108

Figura 4.4 - Descida dos discos 108

Figura 4.5 - Tubo de aço de cintamento e forma de PVC 109

Figura 4.6 - Armadura sendo posicionada 110

Figura 4.7 - Vista geral do bate-estacas (VESSARO et al., 2004) 111

Figura 4.8 - Detalhe do equipamento (VESSARO et al., 2004). 111

Figura 4.9 - Capacete e estaca instrumentada (VESSARO et al., 2004) ... 111

Figura 4.10 - Medidas de nega e repique (VESSARO et al., 2004) 112

Figura 4.11 - Arranjo geral das PCEs (sem escala) 114

Figura 4.12 - Detalhe das áreas de pesquisa 4 e 5 115

Figura 4.13 - Etapas 1, 2, 3 e 4 - área 4. 116

Figura 4.14 - Etapa 5 - área 5. 116

Figura 4.15 - Etapa 6 - área 5.

Figura 4.16 - Poço de inspeção PE4 .....

Figura 4.17 - Ponta da estaca B2(I)

Figura 4.18 - Seqüência da exumação do solo sob a ponta da estaca B2(I) ...... 121

Figura 4.19 - Seqüência da inspeção da ponta da escavação piloto (A1a) 121

Figura 4.20 - Câmara de sucção 122

Figura 4.21 - Ensaio triaxial com sucção controlada 122

Figura 4.22 - Desenho do equipamento e detalhes da caçamba 123

Figura 4.23 - Caçamba vazia 
Figura 4.24 - Caçamba cheia

Figura 4.25 - Vista do fundo

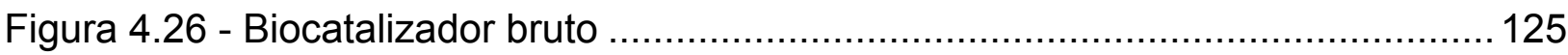

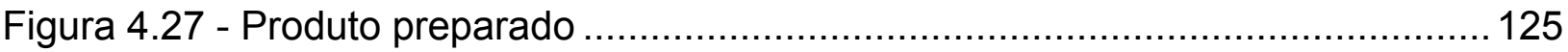

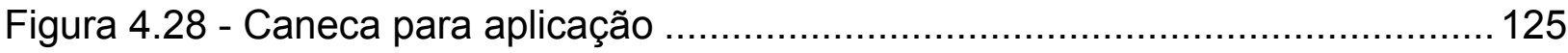

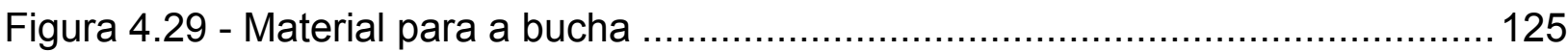

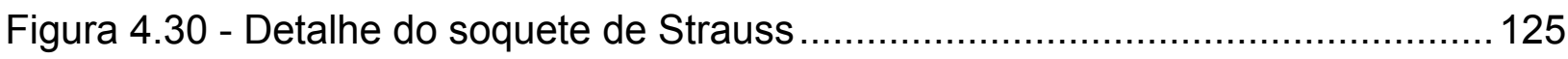

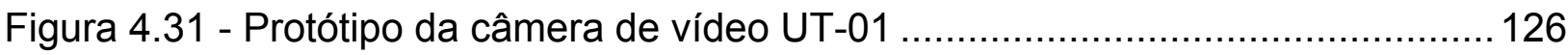

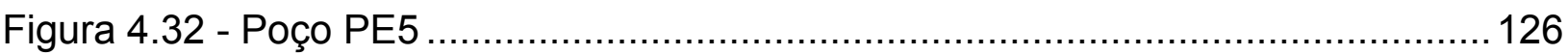

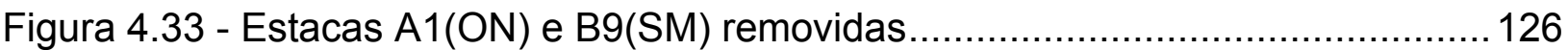

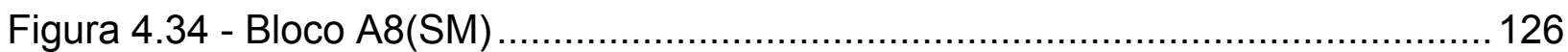

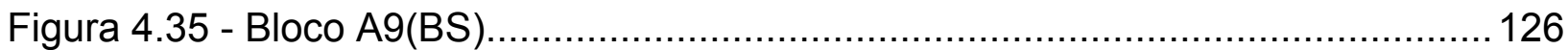

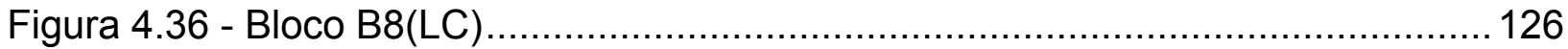

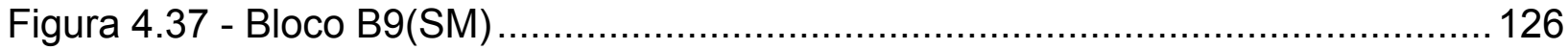

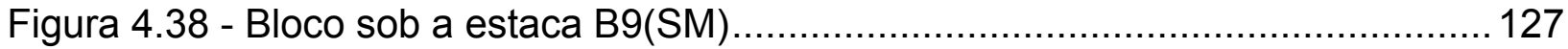

Figura 4.39 - Ensaio triaxial, tipo CD drenado ao ar, em andamento ..........................127

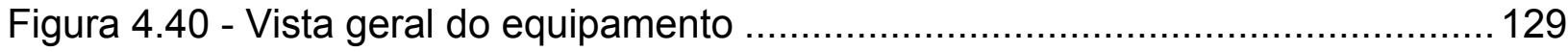

Figura 4.41 - Seqüência da abertura das lâminas do equipamento ……..................... 129

Figura 4.42 - Seqüência da descida da base do equipamento …………………..... 130

Figura 4.43 - Câmera de vídeo UT-01 aperfeiçoada …………………....................... 130

Figura 5.1 - Resultados do CPT14 e a previsão de distribuição de carga ao longo da

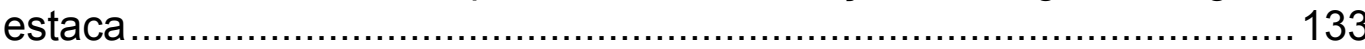

Figura 5.2 - Ensaio para determinação das propriedades mecânicas do concreto ..... 134

Figura 5.3 - Sinal ajustado do $4^{\circ}$ golpe, na estaca A10(BS) .................................. 135

Figura 5.4 - Análise CAPWAP do $4^{\circ}$ golpe, na estaca A10(BS ................................136

Figura 5.5 - Prova de carga dinâmica na estaca A1(O) - Ensaio, sem pré-inundação137

Figura 5.6 - Prova de carga dinâmica na estaca $A 1(O)$ - Reensaio, sem préinundação. 
Figura 5.7 - Prova de carga dinâmica na estaca $A 4(O)$ - Ensaio, sem pré-inundação138

Figura 5.8 - Prova de carga dinâmica na estaca $A 4(O)$ - Reensaio, sem préinundação.

Figura 5.9 - Prova de carga dinâmica na estaca B4(O) - Ensaio, com pré-inundação139

Figura 5.10 - Prova de carga dinâmica na estaca B4(O) - Reensaio, com préinundação

Figura 5.11 - Prova de carga dinâmica na estaca B8(LC) - Ensaio, sem préinundação

Figura 5.12 - Prova de carga dinâmica na estaca B8(LC) - Reensaio, sem préinundação.

Figura 5.13 - Prova de carga dinâmica na estaca B10(LC) - Ensaio, sem préinundação

Figura 5.14 - Prova de carga dinâmica na estaca B10(LC) - Reensaio, sem préinundação

Figura 5.15 - Prova de carga dinâmica na estaca C8(LC) - Ensaio, sem préinundação

Figura 5.16 - Prova de carga dinâmica na estaca C8(LC) - Reensaio, sem préinundação

Figura 5.17 - Prova de carga dinâmica na estaca A8(SM) - Ensaio, sem préinundação

Figura 5.18 - Prova de carga dinâmica na estaca A8(SM) - Reensaio, sem préinundação

Figura 5.19 - Prova de carga dinâmica na estaca B9(SM) - Ensaio, sem préinundação

Figura 5.20 - Prova de carga dinâmica na estaca B9(SM) - Reensaio, sem préinundação

Figura 5.21 - Prova de carga dinâmica na estaca C10(SM) - Ensaio, sem préinundação

Figura 5.22 - Prova de carga dinâmica na estaca C10(SM) - Reensaio, sem préinundação

Figura 5.23 - Prova de carga dinâmica na estaca A9(BS) - Ensaio, sem préinundação

Figura 5.24 - Prova de carga dinâmica na estaca A9(BS) - Reensaio, sem préinundação 
Figura 5.25 - Prova de carga dinâmica na estaca A10(BS) - Ensaio, sem préinundação

Figura 5.26 - Prova de carga dinâmica na estaca A10(BS) - Reensaio, sem préinundação

Figura 5.27 - Prova de carga dinâmica na estaca C9(BS) - Ensaio, sem préinundação

Figura 5.28 - Prova de carga dinâmica na estaca C9(BS) - Reensaio, sem préinundação

Figura 5.29- Aspectos do preparo da ponta da estaca A11(BA)

Figura 5.30 - Prova de carga dinâmica na estaca A11(BA) - Ensaio, sem préinundação

Figura 5.31 - Prova de carga dinâmica na estaca A11(BA) - Reensaio, sem préinundação

Figura 5.32 - Prova de carga dinâmica na estaca A12(BA) - Ensaio, sem préinundação

Figura 5.33 - Prova de carga dinâmica na estaca A12(BA) - Reensaio, sem préinundação

Figura 5.34 - Prova de carga dinâmica na estaca B11(BA) - Ensaio, sem préinundação

Figura 5.35 - Prova de carga dinâmica na estaca B11(BA) - Reensaio, sem préinundação

Figura 5.36 - Prova de carga dinâmica na estaca B19(BA) - Ensaio, com préinundação

Figura 5.37 - Prova de carga dinâmica na estaca B19(BA) - Reensaio, com préinundação

Figura 5.38 - Curva carga $x$ recalque do primeiro ensaio estático na estaca $A 1(O) \ldots 159$

Figura 5.39 - Curva carga x recalque do primeiro reensaio estático na estaca $A 1(0) 160$

Figura 5.40 - Curva carga x recalque dos ensaio e reensaio estáticos na estaca $\mathrm{A} 1(\mathrm{O})$

Figura 5.41 - Curva carga x recalque do primeiro ensaio estático na estaca $A 4(O) \ldots 163$

Figura 5.42 - Curva carga x recalque do primeiro reensaio estático na estaca $A 4(O) 164$

Figura 5.43 - Curvas carga $\times$ recalque de todos os ensaios e reensaios estáticos na estaca $A 4(O)$ 
Figura 5.44 - Ensaio de relaxação para a verificação de tensões residuais na estaca A4.

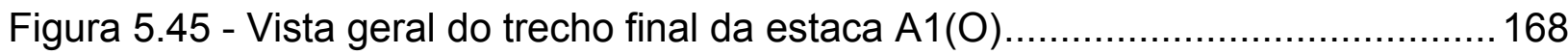

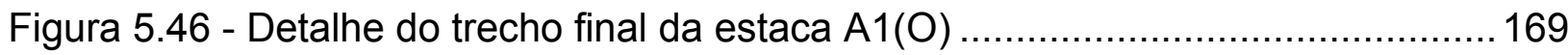

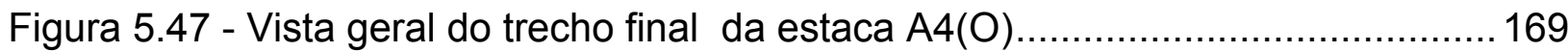

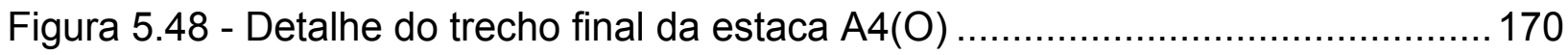

Figura 5.49 - Detalhe da ponta do trado e os volumes não retentivos ..................... 170

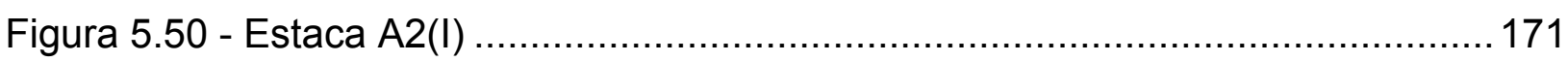

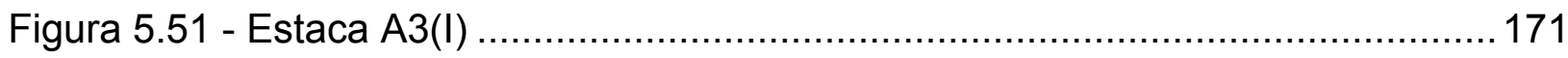

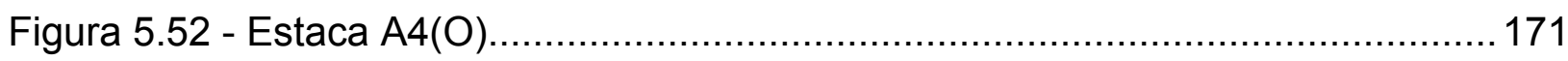

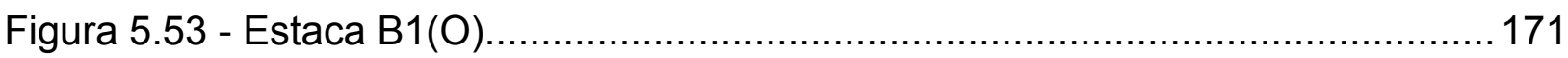

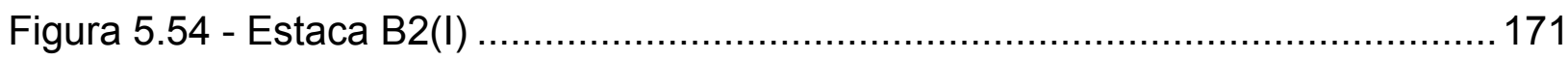

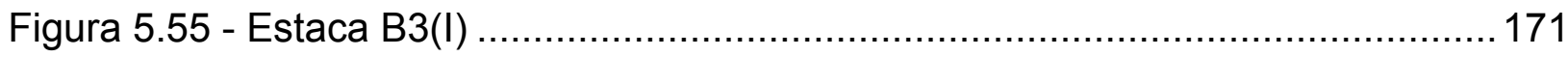

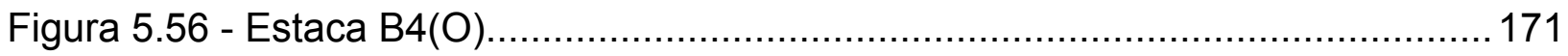

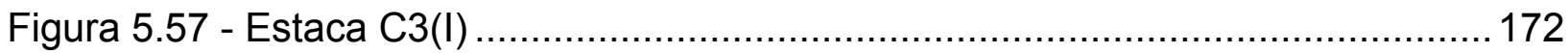

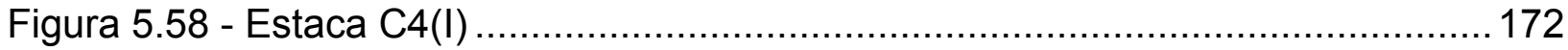

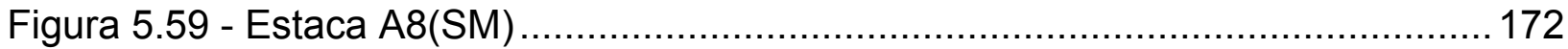

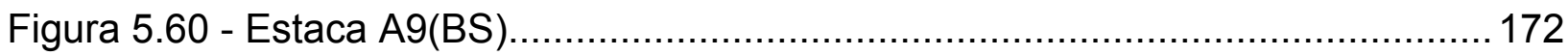

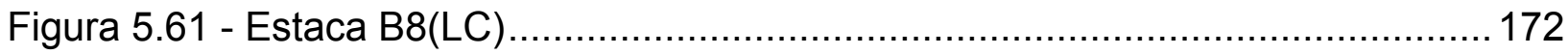

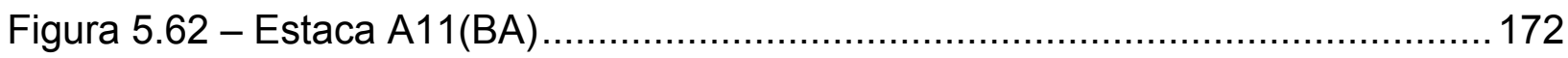

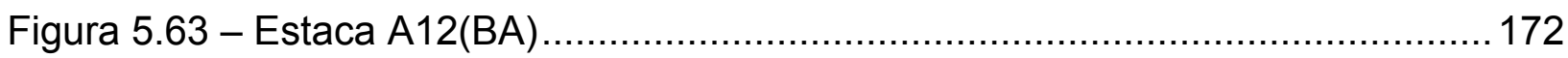

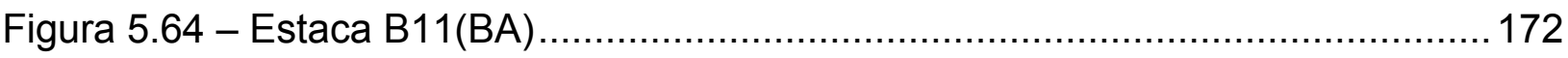

Figura 5.65 - Pesos específicos sob a ponta das estacas da $5^{\mathrm{a}}$ etapa ....................173

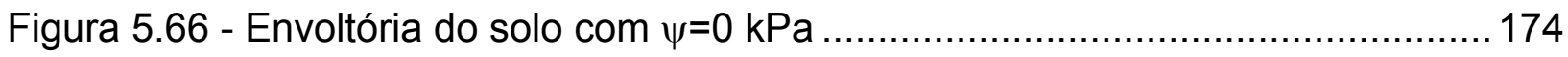

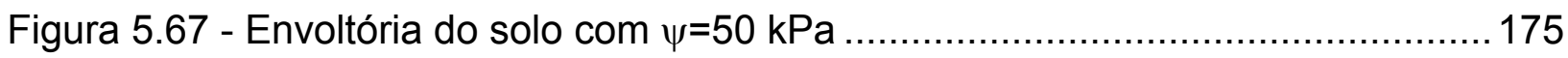

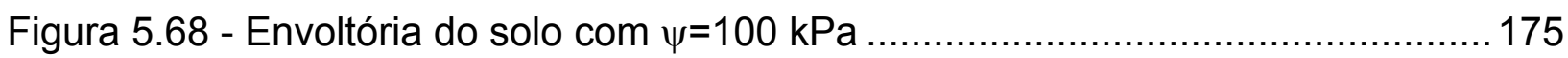

Figura 5.69 - Amostra a 5 cm abaixo e 16 cm de distância do eixo da estaca B9(SM)176 
Figura 5.70 - Amostra a $5 \mathrm{~cm}$ abaixo e $13 \mathrm{~cm}$ de distância do eixo da estaca B9(SM)177

Figura 5.71 - Amostra a $5 \mathrm{~cm}$ abaixo e $6 \mathrm{~cm}$ de distância do eixo da estaca B9(SM). 177

Figura 5.72 - Resistência à compressão simples x distância do eixo da estaca $\mathrm{B} 9(\mathrm{SM})$

Figura 5.73 - Amostra a $5 \mathrm{~cm}$ abaixo e $20 \mathrm{~cm}$ de distância do eixo da ponta de A9(BS)

Figura 5.74 - Amostra a $5 \mathrm{~cm}$ abaixo e $13 \mathrm{~cm}$ de distância do eixo da ponta de A9(BS)

Figura 5.75 - Amostra a $5 \mathrm{~cm}$ abaixo e $8,5 \mathrm{~cm}$ de distância do eixo da ponta de A9(BS)

Figura 5.76 - Pressões disponíveis x abertura das lâminas do TI-01 181 


\section{LISTA DE TABELAS}

Tabela 2.1 - Características dos tipos de ensaios em estacas (HOLEYMAN, 1997) ...... 7

Tabela 2.2 - Critérios de ruptura segundo diversos pesquisadores (VESIC', 1975)......12

Tabela 2.3 - Alguns critérios de ruptura convencional....................................... 13

Tabela 2.4 - Instantes da monitoração da instalação .......................................... 39

Tabela 2.5 - Diâmetros dos revestimentos e das ferramentas de estacas do tipo Strauss (ABEF, 1999)............................................................ 47

Tabela 2.6 - Características principais das estacas Franki (ABEF, 1999)..................50

Tabela 2.7 - Tensão média e fator de segurança de várias estacas (CEPOLINA, 2000)

Tabela 2.8 - Especificações dos materiais das estacas CFA (ABEF, 1999) ...............64

Tabela 2.9 - Cargas de trabalho normalmente utilizadas (FUNDESP, 2000).............66

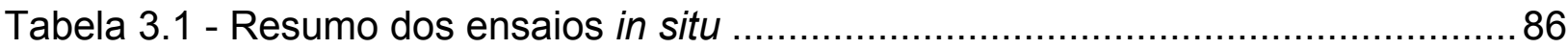

Tabela 3.2 - Resumo dos furos de SPT-T ....................................................... 87

Tabela 3.3 - Propriedades índices do solo do CEEG ..................................... 97

Tabela 3.4 - Parâmetros de adensamento ...................................................... 100

Tabela 3.5 - Ângulo de atrito do solo (ensaios CU) ........................................ 105

Tabela 4.1 - Áreas 4 e 5: Resumo das estacas ensaiadas ...................................... 131

Tabela 5.1 - Resultados das previsões de capacidade de carga ............................ 132

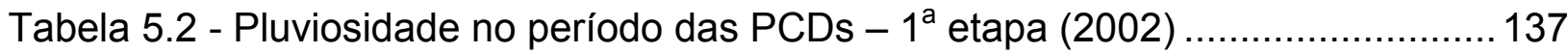

Tabela 5.3 - Pluviosidade no período das PCDs $-2^{\mathrm{a}}$ etapa (2002) ....................... 139

Tabela 5.4 - Pluviosidade no período das PCDs $-5^{a}$ etapa (2005)........................ 140

Tabela 5.5 - Teores de umidade determinados em 19/fev/2005 - PCDs - $5^{\mathrm{a}}$ etapa

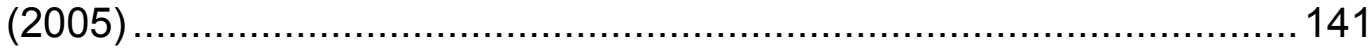

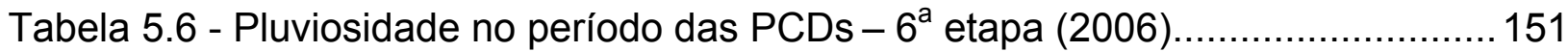

Tabela 5.7 - Resumo dos resultados dos ensaios ......................................... 156

Tabela 5.8 - Resumo dos resultados dos reensaios ....................................... 157 
Lista de tabelas

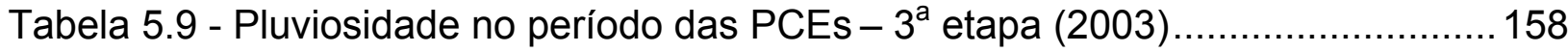

Tabela 5.10 - Resultados dos ensaios triaxiais do tipo CD e drenados ao ar ............179

Tabela 5.11 - Pressões disponíveis $x$ abertura das lâminas do TI-01 ......................181 


\section{SIMBOLOGIA}

$\alpha \quad$ Coeficiente de forma da curva carga $\times$ recalque da equação de Van Der Veen

b Diâmetro do cone

B Diâmetro da estaca

$\beta \quad$ Coeficiente da equação de Van Der Veen

c Coesão total do solo

c' Coesão efetiva do solo

$c_{u} \quad$ Coesão não drenada

CV Coeficiente de variação

$C_{3} \quad$ Quake de ponta

$C_{c} \quad$ Índice de compressão do solo

DFN Deslocamento permanente obtido no ensaio dinâmico pelo método Case

DMX Deslocamento máximo obtido no ensaio dinâmico pelo método Case

$D_{(m, t)} \quad$ Deslocamento da seção $(m)$ da estaca no instante $(t)$

$D_{p} \quad$ Deslocamento máximo da ponta da estaca

E $\quad$ Módulo de elasticidade

EMX Energia máxima obtida no ensaio dinâmico pelo método Case

$E_{s} \quad$ Módulo de deformabilidade do solo

$\varepsilon \quad$ Deformação do solo

fc Resistência do concreto à compressão simples

fck Resistência característica do concreto à compressão simples

$f_{s} \quad$ Atrito lateral do cone

$\phi \quad$ Ângulo de atrito interno do solo 
Simbologia

$\phi^{b} \quad$ Taxa de aumento da resistência ao cisalhamento do solo devido ao aumento da sua sucção matricial

$g$ Aceleração da gravidade

$\gamma \quad$ Peso específico do solo

$h_{\text {crit }} \quad$ Profundidade crítica

IP Índice de plasticidade

$I_{r} \quad$ Índice de rigidez reduzido do solo

$I_{\text {rr }} \quad$ Índice de rigidez do solo

$K_{0} \quad$ Coeficiente de empuxo no repouso

$k_{h} \quad$ Coeficiente de permeabilidade horizontal

$k_{v} \quad$ Coeficiente de permeabilidade vertical

LL Limite de liquidez

LP Limite de plasticidade

$\Lambda \quad$ Comprimento relativo da onda

MQ (Match Quality) Índice de qualidade do ajuste no método Capwap

$v \quad$ Coeficiente de Poisson

$N \quad$ Número de golpes $/ 30 \mathrm{~cm}$

$N_{c}, N_{q}, N_{\gamma} \quad$ Fatores de capacidade de carga

$N_{q}{ }^{*} \quad N_{q}{ }^{*}=N_{q} \times S_{q}$ Fator de capacidade de carga para fundação de seção circular

Q Carga aplicada

$\Delta Q \quad$ Incremento de carga

$q_{c} \quad$ Resistência de ponta do cone

$q_{p, u} \quad$ Carga última da ponta da estaca

$q_{s}(m) \quad$ Quake lateral

$Q_{u} \quad$ Carga última da estaca

$R \quad$ Rigidez da fundação

$R_{L} \quad$ Resistência lateral da estaca 
Simbologia

RMX Resistência máxima obtida no ensaio dinâmico pelo método Case

$R_{P} \quad$ Resistência de ponta da estaca

$R_{S} \quad$ Resistência à compressão simples do solo

$R_{S}(m) \quad$ Capacidade de carga estática do solo referente ao atrito lateral

$R_{s t}(m, t)$ Resistência de atrito local total

$R_{U} \quad$ Resistência última da estaca

$R_{w} \quad$ Índice de subsidência do solo

$\rho \quad$ Recalque da estaca

$\rho_{0} \quad$ Recalque da estaca referente à ruptura convencional

$\Delta \rho \quad$ Incremento de recalque

$\rho_{\ell} \quad$ Recalque da estaca referente à carga limite

$s \quad$ Resistência ao cisalhamento do solo

S\% Grau de saturação do solo

S Nega

$S_{c}, S_{q}, S_{\gamma} \quad$ Fatores de forma da fundação

$\sigma_{a} \quad$ Tensão de pré-adensamento do solo

$\sigma_{o c t} \quad$ Tensão octaédrica do solo

$\sigma_{v} \quad$ Tensão vertical de solo

$\sigma_{1} \quad$ Tensão principal maior do ensaio triaxial

$\sigma_{3} \quad$ Tensão principal menor do ensaio triaxial

$\Psi_{m} \quad$ Sucção matricial do solo

$T_{\text {máx }} \quad$ Torque máximo obtido no ensaio de torque

$\Delta t \quad$ Intervalo de tempo

$V \quad$ Energia total de deformação

$\Delta V \quad$ Incremento de energia

$V_{c} \quad$ Energia complementar 
Simbologia

$V_{c u} \quad$ Energia complementar limite

$w \% \quad$ Teor de umidade do solo

WC Onda medida no ensaio dinâmico

WS Onda calculada no ensaio dinâmico

z Profundidade da fundação 


\section{SUMÁRIO}

1- INTRODUÇÃO

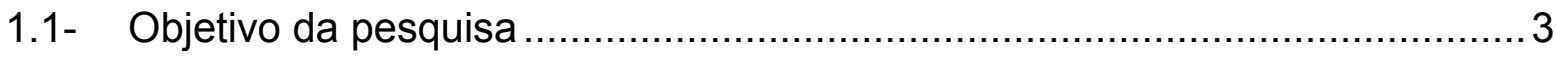

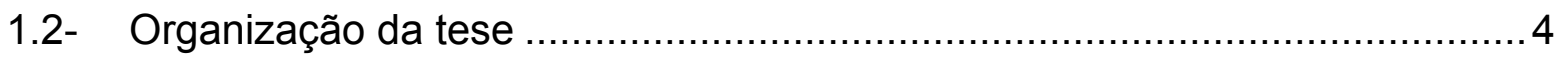

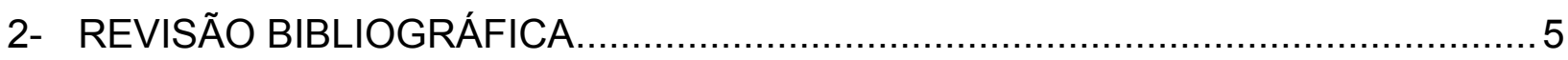

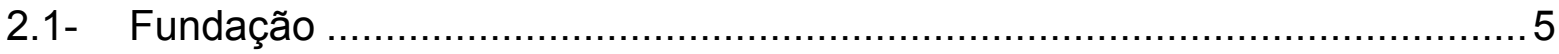

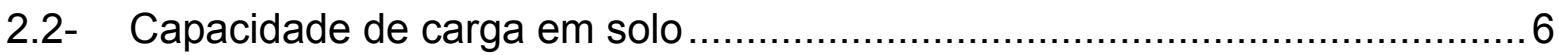

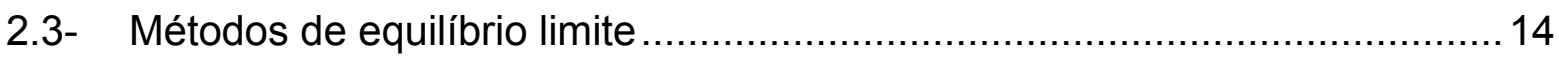

2.4- Teorias de expansão da cavidade ...................................................... 19

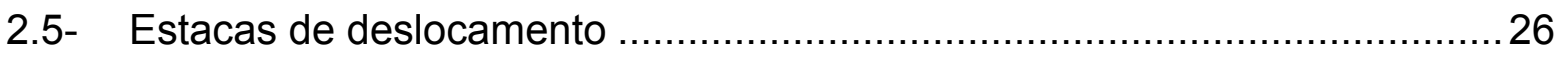

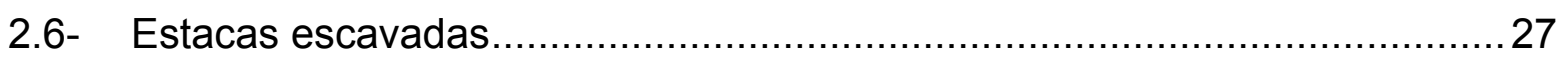

2.7- Influências negativas no comportamento de estacas ...............................2 27

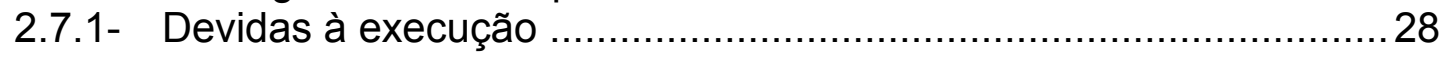

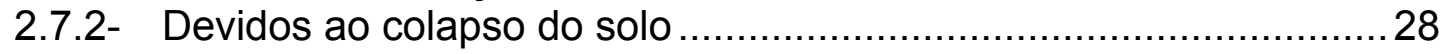

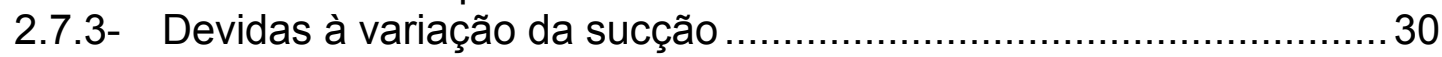

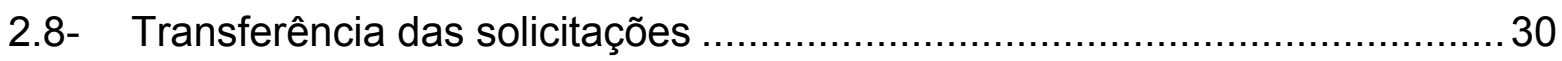

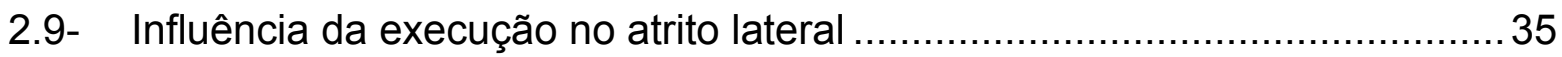

2.10- Influência da execução na resistência de ponta ........................................40

2.11- Comparação entre estacas com fuste moldado in situ ..............................42

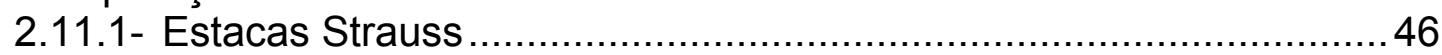

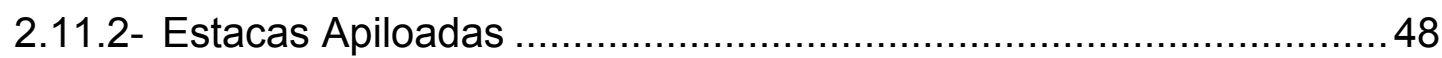

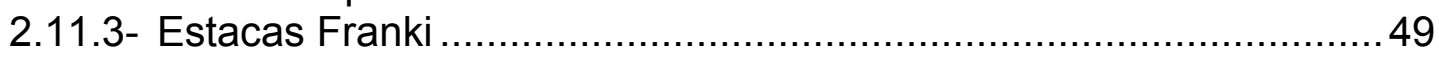

2.11.4- Estacas Escavadas de Pequeno Diâmetro (com trado mecânico) .. 51

2.11.5- Estacas Escavadas de Grandes Dimensões ..................................53

2.11.6- Estacas Raiz e Micro Estacas ........................................................ 58

2.11.7- Estacas Hélice Contínua (CFA - Continuous Flight Auger)...............62

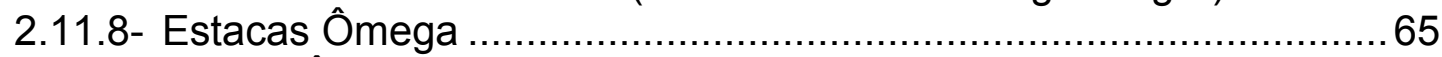

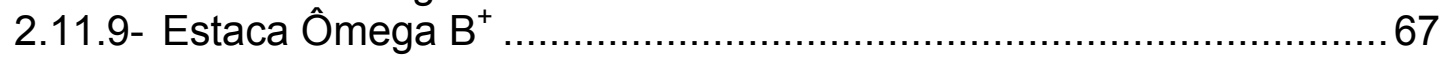

2.11.10- Estacas com alargamento da base ...........................................68

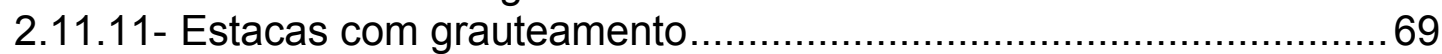

2.11.12- Estacas com tratamento do solo com resinas químicas...................71

2.11.13- Estacas com apiloamento da ponta ............................................ 72

2.11.14- Estaca com expulsão de plug (VB-pile) ......................................73

2.11.15- Método SENTAN............................................................. 74

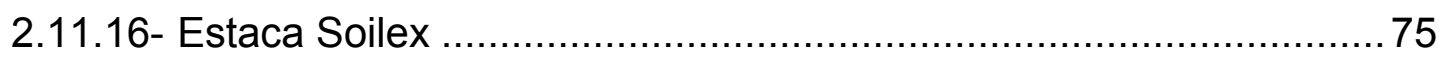

2.11.17- Célula de pré-carga (BOLOGNESI; MORETTO, 1973) ..................76

2.11.18- Célula de pré-carga (LIZZI, 1976) ……...................................77

2.11.19- Célula de pré-carga (Sistema Bauer, 1997) ..................................78 
2.11.20- Célula Expansiva Hidrodinâmica (SILVA, 1983) ……..................... 80

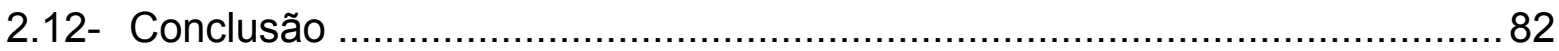

3- CARACTERÍSTICAS DO CAMPO EXPERIMENTAL DA UEL .............................83

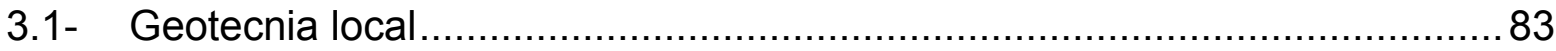

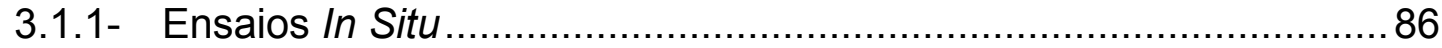

3.1.2- Ensaios de laboratório ..........................................................97

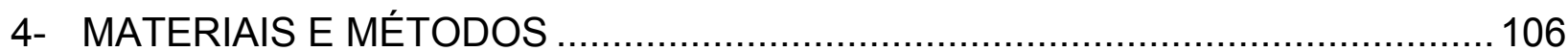

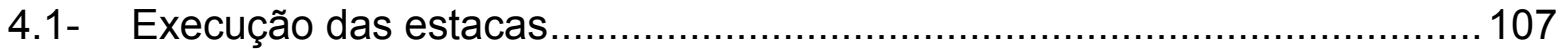

4.2- Execução das provas de carga dinâmicas (PCDs) ..................................110

4.3- Execução das provas de carga estáticas (PCEs) ....................................112

4.4- Etapas da pesquisa .....................................................................114

4.4.1- $1^{\text {a }}$ etapa: PCDs sem inundação............................................... 117

4.4.2- $2^{\mathrm{a}}$ etapa: PCDs com inundação ............................................... 117

4.4.3- $3^{a}$ etapa: PCEs ....................................................................... 118

4.4.4- $4^{a}$ etapa: Poços de inspeção e ensaios de laboratório ................... 119

4.4.5- $5^{\text {a }}$ etapa: PCDs em estacas com ponta modificada, poço de inspeção e ensaios de laboratório ............................................... 122

4.4.6- $\quad 6^{\mathrm{a}}$ etapa: PCDs e poço de inspeção .......................................... 128

5- RESULTADOS: APRESENTAÇÃO E ANÁLISE ............................................... 132

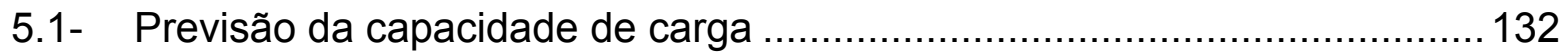

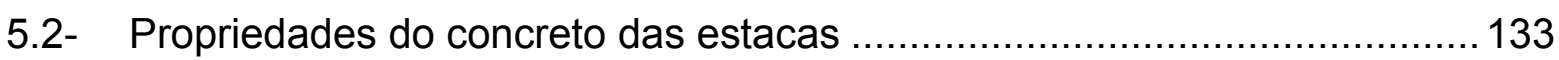

5.3- Provas de carga dinâmica (PCDs) .................................................. 135

5.3.1- $1^{a}$ etapa: Estacas do tipo original $(O)$, sem inundação …………....136

5.3.2- $\quad 2^{\mathrm{a}}$ etapa: Estacas do tipo original (O), com inundação ………….... 139

5.3.3- $\quad 5^{\text {a }}$ etapa: Estacas dos tipos limpa com caçamba (LC), solo melhorado (SM) e "bucha de Strauss" (BS), sem inundação.......... 140

5.3.4- $6^{a}$ etapa: Estacas do tipo base alargada (BA), sem e com pré-

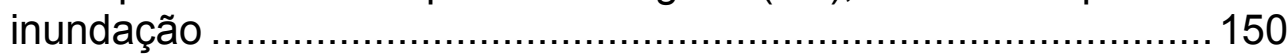

5.3.5- Análise dos resultados das PCDs ............................................ 155

5.4- Provas de carga estática (PCEs) ...................................................... 158

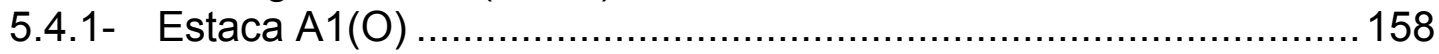

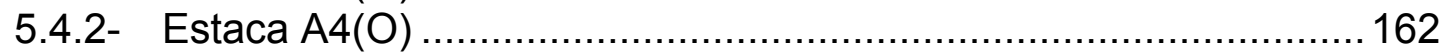

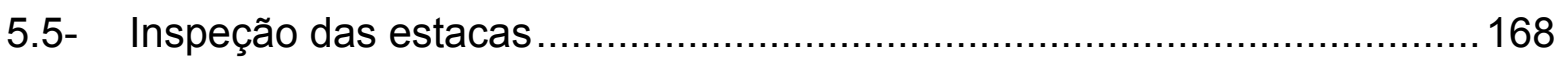

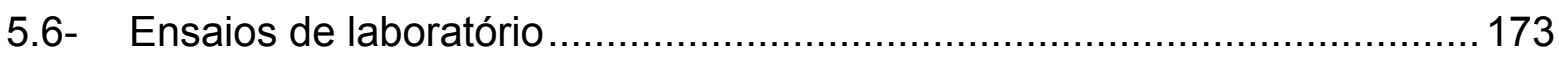

5.7- Especificações teóricas do TI-01 ….................................................. 180

6- CONCLUSÃO E SUGESTÕES PARA FUTURAS PESQUISAS .........................182

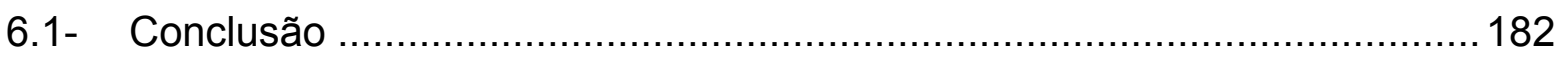

6.2- Sugestões para futuras pesquisas ……………................................ 185

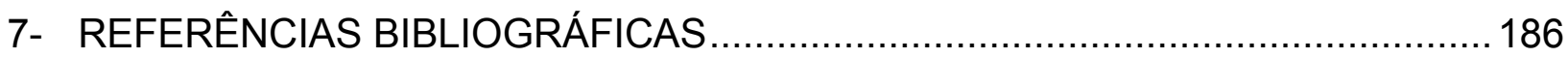




\section{1- INTRODUÇÃO}

Estacas escavadas de pequeno diâmetro têm sido largamente empregadas para cargas de pequena e média magnitudes, devido à sua boa produtividade executiva, com custos reduzidos, associada aos baixos níveis de ruído e vibrações. São executadas por escavação com um trado helicoidal, aberto, contínuo e, geralmente, dotado de uma haste telescópica, para ampliar a profundidade de alcance. O seu uso é indicado para solos com alguma coesão e acima do nível freático, situações em que é possível aprisionar os detritos entre as pás do trado, para a sua remoção. O descarregamento é feito na superfície, girando-se rapidamente o trado.

Em função da sua forma de execução, essas estacas estão sujeitas a variados graus de redução do confinamento do solo e de geração de detritos no fundo da cavidade. A redução do confinamento, em geral, piora as suas características, diminuindo a rigidez e a resistência do solo, enquanto que o acúmulo de detritos impede o contato direto da ponta da estaca com o terreno natural.

Uma grande parte dos equipamentos que executa essas estacas escavadas com trado mecânico é de acionamento elétrico e atinge profundidade de $12 \mathrm{~m}$. Até essa profundidade, a resistência do solo é relativamente baixa. 
A maioria das técnicas que permitem melhorar a contribuição da resistência de ponta de estacas está relacionada a estacas de grandes dimensões e prevêem:

(a) Alargamento da ponta, por escavação (e.g., TOMLINSON, 1977) ou por deslocamento do solo, com aumento da resistência do solo (e.g., LIZZI, 1988 e MASSARSCH et al., 1988);

(b) Aumento da resistência do solo através da redução do volume de vazios, sem aumento do diâmetro da base (e.g., BOLOGNESI; MORETTO, 1973 e KONDOU, 1998), ou através de injeções (e.g., COSTA NUNES; DRINGENBERG, 1984).

No entanto, são poucas as pesquisas que tratam deste assunto, para o caso de estacas de pequeno a médio porte, como as escavadas de pequeno diâmetro.

Adicionalmente a essas dificuldades, em boa parte das regiões Sudeste e Sul do Brasil, há a ocorrência de solos superficiais muito porosos e sensíveis a variações do grau de saturação e, em conseqüência, da sucção matricial atuante e da capacidade de carga de elementos isolados de fundação instalados nesses solos. Havendo diminuição da sucção matricial, decorrente de aumento do grau de saturação, tem-se uma redução da capacidade de carga. Na condição crítica de sucção matricial praticamente nula, ocorrem os mecanismos tradicionalmente conceituados como colapso da estrutura do solo.

O processo de instalação da maioria das estacas escavadas não interfere neste fenômeno, permitindo que ele possa se manifestar, caso ocorram as condições propícias.

Os solos colapsíveis, quando se encontram com baixos teores de umidade, apresentam uma resistência superior à esperada, porém de caráter instável. Esse acréscimo da resistência se dá devido à pressão de sucção que se desenvolve nos seus poros e afeta a capacidade de carga 
por influir na parcela da resistência ao cisalhamento do solo caracterizada pela coesão, conforme demonstrado por Fredlund e Rahardjo (1993), apud Cintra et al (2005):

$$
c=c^{\prime}+\psi_{m} \cdot \operatorname{tg} \phi^{b}
$$

em que c' é a coesão efetiva, $\Psi_{\mathrm{m}}$, a sucção matricial do solo e $\phi^{\mathrm{b}}$, a taxa de aumento da resistência ao cisalhamento do solo devido ao aumento da sua sucção matricial.

Logo, o aumento do teor de umidade do solo provoca a redução da sua capacidade de carga, até um valor mínimo, correspondente à sucção praticamente nula. Isso implica que a capacidade de carga de um elemento de fundação é dependente das condições sazonais de precipitação pluviométrica.

\section{1- Objetivo da pesquisa}

O objetivo da pesquisa é o de pesquisar formas de aumentar a carga admissível de estacas de pequeno diâmetro, através de modificações na execução da ponta e a verificação do seu comportamento através de provas de carga dinâmica. Para tanto, foram buscadas três linhas de ação:

(a) Investigar as causas da pobre contribuição da resistência de ponta;

(b) Desenvolver técnicas e equipamentos que permitam intervenção viável no processo executivo tradicional;

(c) Comparar quatro formas de modificação da ponta. 


\section{2- Organização da tese}

O capítulo 1 apresenta um panorama do problema, os objetivos da pesquisa e a forma da sua organização.

O capítulo 2 apresenta, inicialmente, os conceitos teóricos relativos à determinação da carga admissível de estacas, os tipos conceituais de estacas, os efeitos devidos à execução, os mecanismos de transferência das solicitações e as formas utilizadas para modificar a ponta e aumentar a carga admissível de estacas.

O capítulo 3 apresenta as características geotécnicas da área onde foram feitos os experimentos, o Campo Experimental de Engenharia Geotécnica (CEEG), da Universidade Estadual de Londrina (UEL).

O capítulo 4 apresenta as especificações dos materiais, as etapas e a metodologia empregada na pesquisa.

O capítulo 5 apresenta os resultados obtidos e as análises efetuadas.

O capítulo 6 apresenta a conclusão obtida, com base nos resultados e nas análises.

Finalmente, o capítulo 7 apresenta as referências de toda a bibliografia utilizada. 


\section{2- REVISÃO BIBLIOGRÁFICA}

\section{1- Fundação}

Estrutura é o sistema destinado a absorver e transmitir ao maciço de solos as cargas funcionais, com segurança, economia, confiabilidade e durabilidade, Aoki (2001). É um sistema composto por uma superestrutura, denominada comumente de estrutura e por uma infraestrutura, denominada fundação.

A fundação é a parte da estrutura encarregada de absorver as cargas provenientes da superestrutura e transmiti-las ao maciço de solos, de forma a garantir as segurança, economia, confiabilidade e durabilidade requeridas. É composto por:

(a) Todos os elementos isolados de fundação que trabalham em conjunto, transferindo as solicitações oriundas da estrutura superior para o maciço geotécnico;

(b) Porção volumétrica do maciço geotécnico limitada por uma superfície tida como teoricamente indeslocável.

Elemento isolado de fundação é um subsistema da fundação composto por:

(a) Elemento estrutural, raso ou enterrado, destinado a transmitir as solicitações de um determinado ponto da estrutura superior para uma porção do maciço de geotécnico; 
(b) Porção do maciço geotécnico que absorve as solicitações transmitidas pelo elemento estrutural.

Dentre as fundações profundas, um tipo muito utilizado é o das estacas, podendo ser, de acordo com seu processo executivo, classificadas conceitualmente como estacas de deslocamento (com fuste pré-fabricado ou moldado in situ) e estacas escavadas (moldadas in situ).

\section{2- Capacidade de carga em solo}

A capacidade de carga aqui mencionada deve ser entendida como a capacidade de carga à compressão do elemento isolado de fundação, ou seja, a carga que provoca a ruptura desse sistema e cujo valor é limitado pela resistência do elemento estrutural (CINTRA; AOKI, 1999). Do ponto de vista geotécnico, a capacidade de carga é a máxima reação disponibilizada pelo solo. É composta pelas parcelas referentes ao atrito/adesão entre a superfície lateral da estaca com o solo e a resistência ao cisalhamento oferecida pelo solo na área da ponta da estaca.

A verificação da capacidade de carga de um elemento isolado de fundação é feita através de estados limites e deve atender aos:

(a) Estado Limite Último (ELU)

Relacionado ao esgotamento da capacidade resistente do elemento estrutural de fundação ou do maciço de solo encarregado de absorver as solicitações, no todo ou em parte, causando a perda de funcionalidade e de utilização.

Neste estado devem ser verificadas as condições tanto de ruptura, instabilidade elástica e flambagem do elemento estrutural, quanto de deformação plástica excessiva do maciço. 
(b) Estado Limite de Utilização (ELUt)

Relacionado à deformação excessiva do maciço de solo (recalques excessivos), conduzindo à propagação de solicitações para as quais a superestrutura não está preparada, com perda da sua estabilidade.

A determinação da capacidade de carga requer, então, o estabelecimento de um critério de ruptura que possa atender a estes estados limites. A ruptura pode ser física ou convencional.

Segundo Tejchman e Gwizdala (1988), o comportamento de uma fundação e a sua capacidade de carga podem ser determinados através da obtenção da correspondente curva carga versus recalque em ensaios de campo, denominados de provas de carga.

As provas de carga são, comumente, designadas de ensaios de carregamento estático ou dinâmico. As características básicas dos diferentes tipos de ensaios em estacas podem ser vistas na Tabela 2.1 (HOLEYMAN, 1997).

Tabela 2.1 - Características dos tipos de ensaios em estacas (HOLEYMAN, 1997)

\begin{tabular}{ccccc}
\hline Item & $\begin{array}{c}\text { Ensaios de } \\
\text { integridade }\end{array}$ & $\begin{array}{c}\text { Ensaios dinâmicos } \\
\text { de alta deformação }\end{array}$ & $\begin{array}{c}\text { Ensaios } \\
\text { cinéticos }\end{array}$ & $\begin{array}{c}\text { Ensaios } \\
\text { estáticos }\end{array}$ \\
\hline $\begin{array}{c}\text { Massa do martelo } \\
(\mathbf{k g})\end{array}$ & $0,5 \sim 5$ & $2.000 \sim 10.000$ & $2.000 \sim 5.000$ & $\mathrm{~N} / \mathrm{A}$ \\
\hline $\begin{array}{c}\text { Deformação pico } \\
\text { da estaca ( } \boldsymbol{\mu} \text { str) }\end{array}$ & $2 \sim 10$ & $500 \sim 1.000$ & 1.000 & 1.000 \\
\hline $\begin{array}{c}\text { Velocidade pico } \\
\text { da estaca }(\mathbf{m m} / \mathbf{s})\end{array}$ & $10 \sim 40$ & $2.000 \sim 4.000$ & 500 & $10^{-3}$ \\
\hline $\begin{array}{c}\text { Força de } \\
\text { Pico }(\mathbf{k N})\end{array}$ & $2 \sim 20$ & $2.000 \sim 10.000$ & $2.000 \sim 10.000$ & $2.000 \sim 10.000$ \\
\hline $\begin{array}{c}\text { Duração da força } \\
\text { (ms) }\end{array}$ & $0,5 \sim 2$ & $5 \sim 20$ & $50 \sim 200$ & $10^{7}$ \\
\hline $\begin{array}{c}\text { Aceleração da } \\
\text { estaca (g) }\end{array}$ & 50 & 500 & $0,5 \sim 1$ & $10^{-14}$ \\
\hline $\begin{array}{c}\text { Deslocamento da } \\
\text { estaca (mm) }\end{array}$ & 0,01 & $10 \sim 30$ & 50 & $>20$ \\
\hline $\begin{array}{c}\text { Comprimento } \\
\text { relativo onda } \Lambda\end{array}$ & 0,1 & 1,0 & 10 & $10^{8}$ \\
\hline
\end{tabular}


Segundo Holeyman (1997), os ensaios podem ser separados em estáticos, cinemáticos e dinâmicos, de acordo com as combinações de comprimento relativo da onda com a aceleração (Figura 2.1).

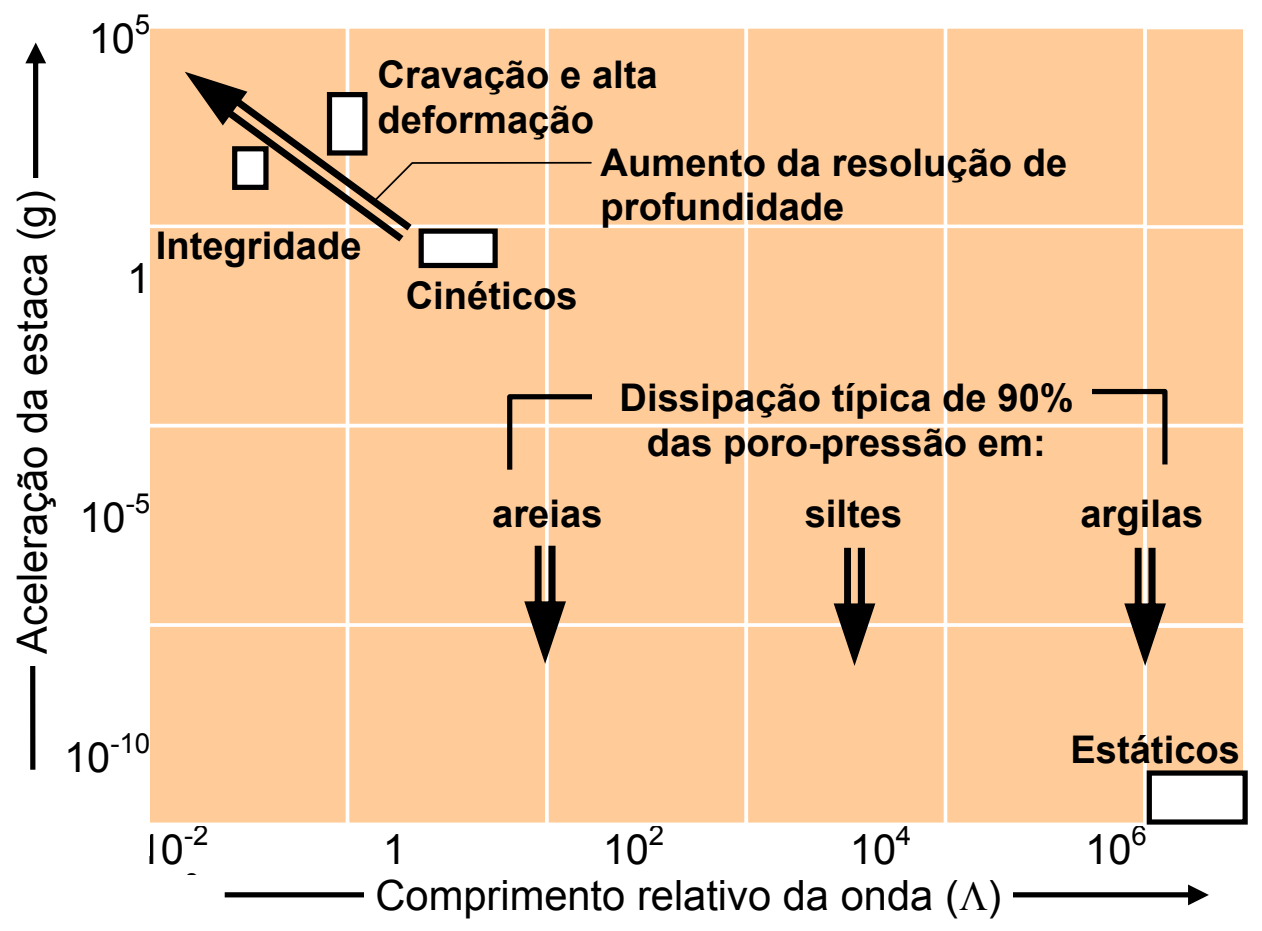

Figura 2.1 - Diferentes tipos de ensaios em estacas (HOLEYMAN, 1997)

O tipo de ensaio atualmente mais empregado é o de carregamento estático porque utiliza conceituação e equipamento mais simples, tendo sido o primeiro a ser utilizado.

O resultado de uma prova de carga estática é uma curva carga versus recalque, geralmente com uma região a partir da qual apresenta uma curvatura maior. A ruptura física do sistema estaca-solo pode ser definida como a condição onde um elemento isolado de fundação apresenta recalque crescente e infinito, sob solicitação de uma carga constante, tida como de ruptura.

Cuidado especial deve ser dado à interpretação da curva carga versus recalque porque, além da complexidade natural, pode, em determinadas situações, ser dependente da escala de desenho utilizada. 
Como alternativa para a definição da ruptura física, Décourt (1996) propõe a utilização do conceito de rigidez, definido como a relação entre a carga aplicada e o recalque decorrente.

$$
R=\frac{Q}{\rho}
$$

A tendência é que haja diminuição da rigidez à medida que os recalques aumentem. Usando este conceito, Décourt propõe a seguinte equação:

$$
Q_{u}=\lim \frac{Q}{\rho} \quad \text { quando } \rho \rightarrow \infty
$$

O que significa que a rigidez do elemento isolado de fundação, para um valor limite de carga, é nula.

Para a determinação da carga que leva à rigidez nula, propõe que seja traçada uma curva com os valores de rigidez $R$ colocada nas ordenadas e os valores de carga $Q$ nas abscissas. Se a prova de carga for levada a pequenos valores de $R$, pode ser usada extrapolação linear ou logarítmica para estimar a ruptura física.

Segundo Décourt, o método é confiável para as estacas de deslocamento, mas não para as escavadas, uma vez que estas últimas têm a característica de não apresentarem pico para a capacidade de carga da ponta, mesmo sob grandes deformações.

Segundo Aoki (1997), tanto o critério de ruptura que estabelece recalques infinitos, quanto a equação proposta por Décourt, requerem energia de deformação infinita, situação impossível na prática e, portanto, inadequada para fins de engenharia.

Aoki (1997) propõe uma abordagem baseada na energia complementar $V_{c}$ da curva carga versus recalque. Neste modelo, a ruptura é determinada para o valor de carga onde a taxa de crescimento da energia complementar $V_{c}$ tende a zero. 
Para um ensaio de carregamento estático típico, com um ciclo de carga e descarga $Q$ e $n$ incrementos finitos $\Delta Q$, aplicados em intervalos de tempo $\Delta t$ e diâmetro da estaca $B$, Aoki define os elementos de uma curva carga versus recalque típica conforme a Figura 2.2.

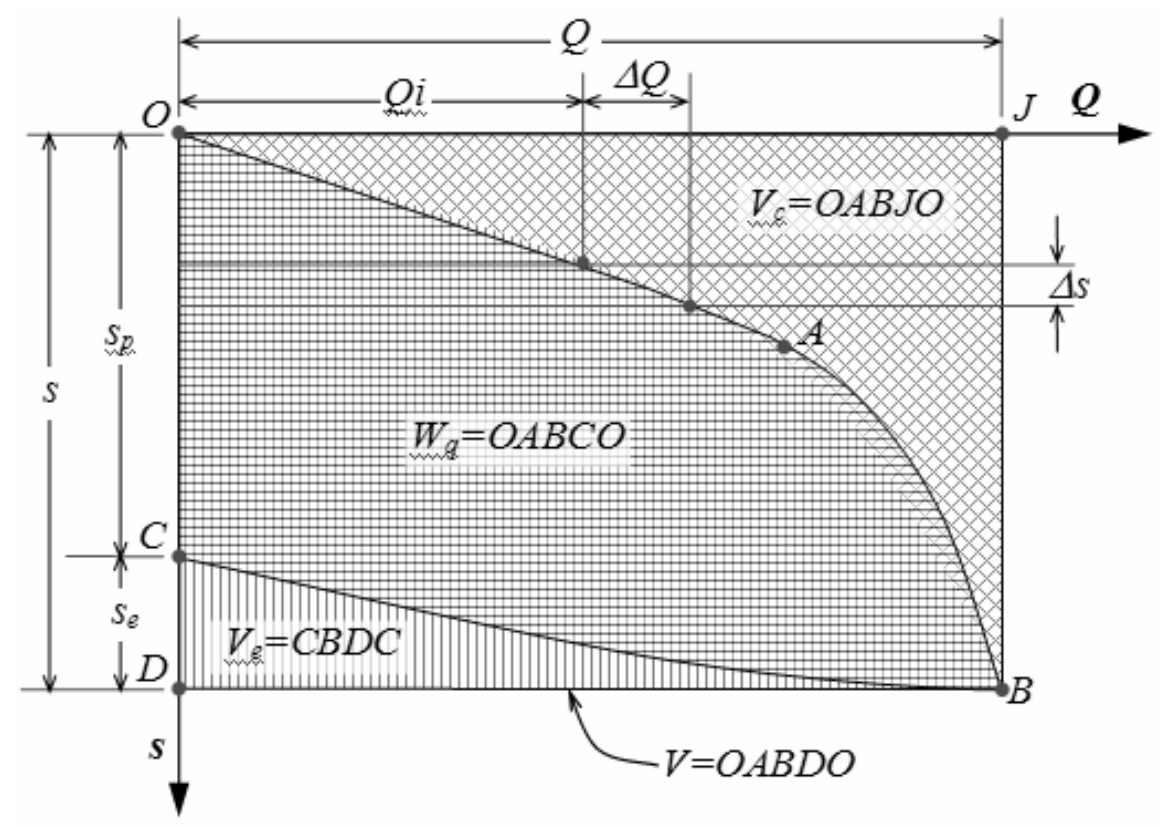

Figura 2.2 - Curva carga versus recalque - ensaio de carregamento estático (AOKI, 1997)

Onde as equações que exprimem a função carga versus recalque são:

A carga $Q$ no final do $n^{\text {ésimo }}$ incremento $\Delta Q$ é:

$$
Q=\sum_{i=1}^{n} \Delta Q
$$

O recalque $s$ no final do $n^{\text {ésimo }}$ incremento $\Delta s$ é:

$$
s=\sum_{i=1}^{n} \Delta s
$$

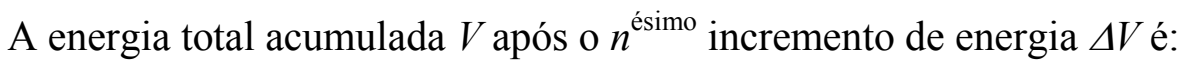

$$
V=\sum_{i=1}^{n} \Delta V
$$


A linha $O A B C$ representa a trajetória final do deslocamento do topo da estaca. $\mathrm{O}$ trecho $O A$ representa a trajetória de deslocamento linear, o trecho $A B$ representa a sua trajetória não linear e o recalque total $s$, está representado pelo trecho $D O$. A descarga está representada pelo trecho $B C$.

Após a descarga, o recalque elástico $s_{e}$ (trecho $D C$ ) é recuperado e resta o recalque plástico $s_{p}$ (trecho $\mathrm{CO}$ ).

A área $O A B D C O$ representa a energia total de deformação $V$, acumulada no sistema.

A área $O A B C O$ representa o trabalho $W_{p}$ que provoca o recalque plástico $s_{p}$.

A área $C B D C$ representa a energia de deformação elástica $V_{e}$, restituída ao sistema.

Finalmente, a área $O A B J O$ representa a energia complementar $V_{c}$.

Na prática, a carga última é determinada para uma limitação de valor, natureza ou taxa de variação do recalque, originando um deslocamento de valor finito (AOKI, 1997). Para Van Impe (1991), apud Aoki (1997), a carga de ruptura corresponde à:

(a) Ruptura física do solo, para a condição onde: $\quad \frac{\Delta \rho}{\Delta Q}=\infty$

(b) Ruptura convencional, para a condição onde: $\quad \frac{\rho_{0}}{B}=10 \%$

(c) Carga limite $Q_{l}$, para a condição onde:

$$
\frac{\rho_{l}}{B}=2,5 \%
$$

Vesic' (1975), mostra que não existe consenso para os critérios de ruptura entre os diversos pesquisadores, conforme a Tabela 2.2. 
Tabela 2.2 - Critérios de ruptura segundo diversos pesquisadores (VESIC', 1975)

\begin{tabular}{|c|c|c|c|}
\hline Critério & Recalque & Valor & Referência \\
\hline \multirow{2}{*}{$\begin{array}{c}\text { Limitando-se o recalque } \\
\text { total }\end{array}$} & Absoluto & $2,5 \mathrm{~cm}$ & Holanda e Código de Nova York \\
\hline & Relativo & $10 \% \phi_{\text {estaca }}$ & Inglaterra \\
\hline \multirow{3}{*}{$\begin{array}{l}\text { Limitando-se o recalque } \\
\text { permanente }\end{array}$} & & $0,64 \mathrm{~cm}$ & AASHO \\
\hline & & $0,84 \mathrm{~cm}$ & Magnel, 1948 \\
\hline & & $1,27 \mathrm{~cm}$ & Código de Boston \\
\hline $\begin{array}{c}\text { Limitando-se a razão } \\
\text { recalque } \\
\text { permanente/recalque } \\
\text { elástico }\end{array}$ & & 1,5 & Christiani e Nielsen \\
\hline $\begin{array}{l}\text { Razão máxima entre } \\
\text { incremento recalque } \\
\text { elástico/incremento } \\
\text { recalque permanente }\end{array}$ & & & Széchi, 1961 \\
\hline \multirow{3}{*}{$\begin{array}{l}\text { Limitando-se a razão } \\
\text { recalque/carga }\end{array}$} & Total & $0,02 \mathrm{~cm} / \mathrm{t}$ & Califórnia, Chicago \\
\hline & & $0,08 \mathrm{~cm} / \mathrm{t}$ & Incremental Ohio \\
\hline & 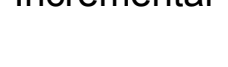 & $0,13 \mathrm{~cm} / \mathrm{t}$ & Incremental Raymond Co. \\
\hline \multirow{2}{*}{$\begin{array}{c}\text { Limitando-se a razão } \\
\text { recalque } \\
\text { permanente/carga }\end{array}$} & Total & $0,02 \mathrm{~cm} / \mathrm{t}$ & Código de Nova York \\
\hline & Incremental & $0,08 \mathrm{~cm} / \mathrm{t}$ & Raymond Co. \\
\hline $\begin{array}{c}\text { Razão máxima entre } \\
\text { incremento } \\
\text { recalque/incremento } \\
\text { carga }\end{array}$ & & & Vesic', 1963 \\
\hline $\begin{array}{c}\text { Máxima curvatura } \\
\log (\text { recalque)/log(carga) }\end{array}$ & & & De Beer, 1967 \\
\hline $\begin{array}{c}\text { Postulado de Van der } \\
\text { VEEN }\end{array}$ & & & $W=\beta \cdot \ln \left(1-Q / Q_{u}\right)$ \\
\hline
\end{tabular}

A abordagem através da energia complementar proposta por Aoki admite que a curva carga versus recalque corresponda à expressão de Van der Veen (1953), sendo expressa por:

$$
V_{c}=\frac{Q_{u}}{\alpha} \cdot\left[1-(1+\alpha \cdot \rho) \cdot \exp ^{-\alpha \cdot \rho}\right]
$$


onde:

$$
\begin{aligned}
& \mathrm{V}_{\mathrm{c}} \rightarrow \text { energia complementar } \\
& \mathrm{Q}_{\mathrm{u}} \rightarrow \text { resistência última } \\
& \alpha \rightarrow \text { coeficiente de forma da curva carga versus recalque } \\
& \rho \rightarrow \text { recalque }
\end{aligned}
$$

No limite $\rho \rightarrow \infty$, a ruptura física corresponde à energia complementar limite $V_{c u}$, expressa por:

$$
V_{c u}=\frac{Q_{u}}{\alpha}, \text { quando esta se torna constante. }
$$

Quando não é possível caracterizar perfeitamente a ruptura física, seja pela dificuldade desta interpretação decorrente da complexidade das propriedades do solo ou pela magnitude dos deslocamentos necessários para a mobilização da ruptura física, muitas vezes é necessário o estabelecimento de um outro critério de ruptura, dito convencional.

Alguns dos critérios de ruptura convencional bastante difundidos no nosso meio técnico estão mostrados na Tabela 2.3.

Tabela 2.3 - Alguns critérios de ruptura convencional

\begin{tabular}{cccc}
\hline Tipo de estaca & Recalque & Valor & Referência \\
\hline Deslocamento & Absoluto & $2,5 \mathrm{~cm}$ & Terzaghi \\
\hline Escavada & Relativo & $10 \% \phi_{\text {estaca }}$ & De Beer \\
\hline & Relativo & $30 \% \phi_{\text {estaca }}$ & De Beer \\
\hline & Relativo & $\frac{R \cdot L}{A \cdot E}+\frac{D}{30}$ & NBR-6122/96 (ABNT) \\
\hline
\end{tabular}


A capacidade de carga das estacas também pode ser estudada por formulação teórica. Neste caso, para a determinação da carga admissível não deve ser utilizado coeficiente de segurança inferior a 3 (CINTRA; AOKI, 1999).

Como o foco deste trabalho é a verificação da carga admissível de estacas com ponta modificada, será feita uma breve revisão das teorias que tratam da resistência de ponta, que são os métodos de equilíbrio limite e as teorias de expansão de cavidades.

\section{3- Métodos de equilíbrio limite}

Os métodos de equilíbrio limite são baseados em superfícies de ruptura no estado plano de deformação. O mecanismo de ruptura assumido é formado por planos de escorregamento e o estudo feito através da teoria da plasticidade.

A capacidade de carga é dependente da superfície de ruptura que é desenvolvida pela estaca, portanto, a sua determinação de uma forma mais realista possível é um fator determinante para a qualidade desta estimativa.

Existem várias propostas buscando reproduzir as superfícies de ruptura das estacas. Os principais modelos, segundo diversos autores, estão mostrados na Figura 2.3 (VESIC', apud CINTRA; AOKI, 1999). A proposta clássica de Terzaghi foi aperfeiçoada por Meyerhof, com a consideração da resistência ao cisalhamento do solo acima da ponta da estaca. A proposta de Skempton, Yassin e Bishop é a primeira que considera a teoria de expansão de cavidades. 


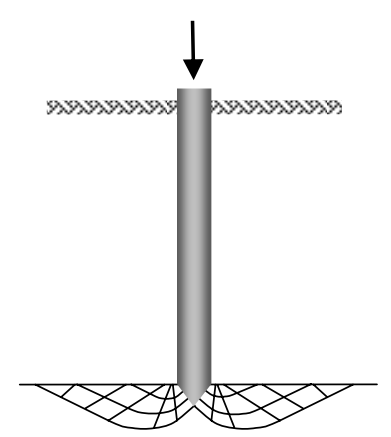

Terzaghi

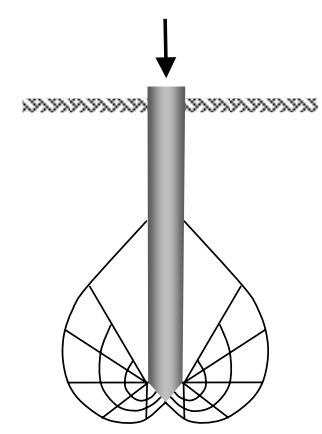

De Beer

Jáky

Meyerhof
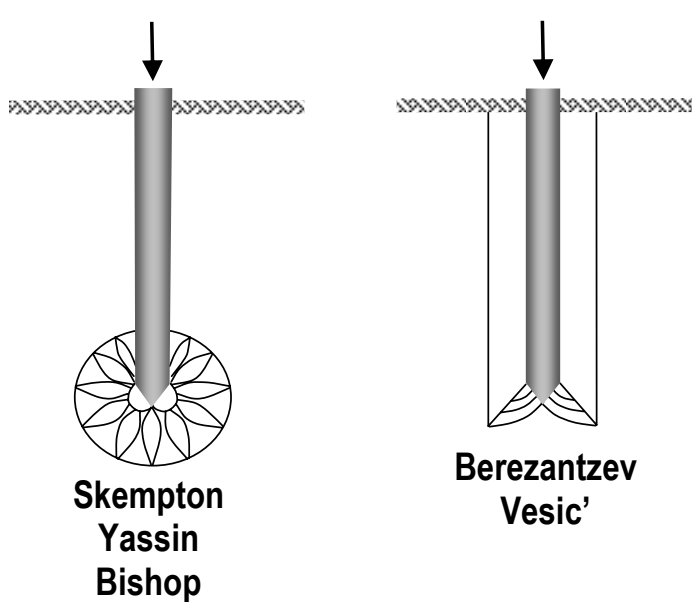

Berezantzev

Vesic'

Figura 2.3 - Superfícies de ruptura de estacas segundo diversos autores (VESIC', apud CINTRA; AOKI, 1999)

A maioria das formulações está baseada nos trabalhos clássicos de Prandtl (1921) e Reissner (1924), a partir dos quais foram feitas adaptações para atender às características específicas de cada formulação.

Um trabalho clássico é o de Terzaghi (1943), baseado em formulação própria (1925) e nos trabalhos citados acima. Sua formulação geral é:

$$
q_{p, u}=c \cdot N_{c} \cdot S_{c}+\gamma \cdot z \cdot N_{q} \cdot S_{q}+\frac{B}{2} \cdot \gamma \cdot N_{\gamma} \cdot S_{\gamma}
$$

onde:

$q_{p, u} \rightarrow$ capacidade de carga (carga última) da ponta

$N_{c}, N_{q}$ e $N_{\gamma} \rightarrow$ fatores de capacidade de carga

$S_{c}, S_{q}$ e $S_{\gamma} \rightarrow$ fatores de forma da fundação

$c \rightarrow$ coesão do solo no nível de apoio

$z \rightarrow$ profundidade do apoio 
$\gamma \rightarrow$ peso específico da camada de solo

$B \rightarrow$ dimensão da fundação

No caso de solos granulares $(c=0)$, a equação passa a ser escrita:

$$
q_{p, u}=\gamma \cdot z \cdot N_{q} \cdot S_{q}+\frac{B}{2} \cdot \gamma \cdot N_{\gamma} \cdot S_{\gamma}
$$

Para fundações profundas, onde a relação $z / B$ é muito grande, a última parcela (devida ao peso próprio) pode ser desprezada, passando a ser escrita:

$$
q_{p, u}=\gamma \cdot z \cdot N_{q} \cdot S_{q}
$$

Para estacas de seção circular, o fator de forma é incorporado ao fator de capacidade de carga, gerando um novo fator de capacidade de carga $\left(N_{q}^{*}=N_{q} \cdot S_{q}\right)$, resultando em:

$$
q_{p, u}=\gamma \cdot z \cdot N_{q}^{*}
$$

A Figura 2.4 (VESIC', apud CINTRA; AOKI, 1999) mostra os valores de fatores de capacidade de carga $\mathrm{N}_{\mathrm{q}}{ }^{*}$, em função do ângulo de atrito do solo, de acordo com diversos mecanismos de ruptura de estacas. 


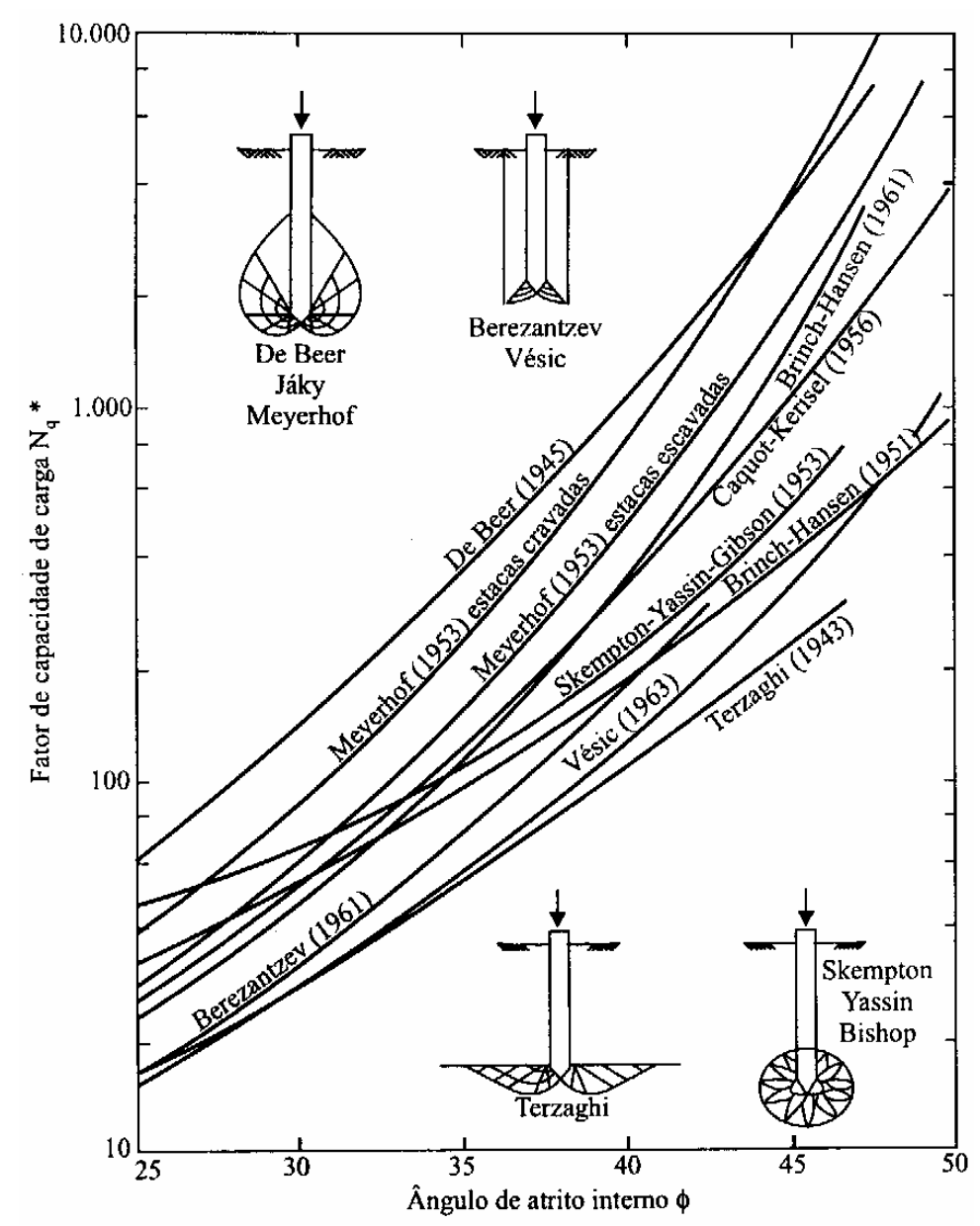

Figura 2.4 - Fator de capacidade de carga $\mathrm{N}_{\mathrm{q}}{ }^{*}$ para diversos mecanismos de ruptura de estacas (VESIC', apud CINTRA; AOKI, 1999)

Como pode ser observado, estes valores podem sofrer variação de até dez vezes, inviabilizando estes métodos para a determinação de capacidade de carga (CINTRA; AOKI, 1999).

Estudos feitos por Kerisel (1964), a partir de resultados de ensaios de cone e de estacas em areias finas compactas, mostraram que havia diferenças na resistência de ponta em função do diâmetro. Os resultados mostraram que a resistência era inversamente proporcional ao diâmetro da ponta.

Este efeito foi analisado por De Beer (1963) que verificou que a resistência de ponta era totalmente mobilizada logo na penetração do cone enquanto que, para estacas de grande diâmetro, a mobilização total só ocorria após uma certa profundidade. 
Esta profundidade foi denominada de profundidade crítica ou penetração para mecanismo completo de ruptura $\left(h_{\text {crit }}\right)$. De Beer usou a formulação de Meyerhof (1951) e concluiu que a resistência de ponta cresce linearmente com a profundidade até atingir a penetração que mobiliza o mecanismo completo de ruptura para aquele diâmetro.

Isto foi denominado efeito de embutimento e a sua interpretação pode ser vista na Figura 2.5 (De BEER, apud SILVA, 2001).

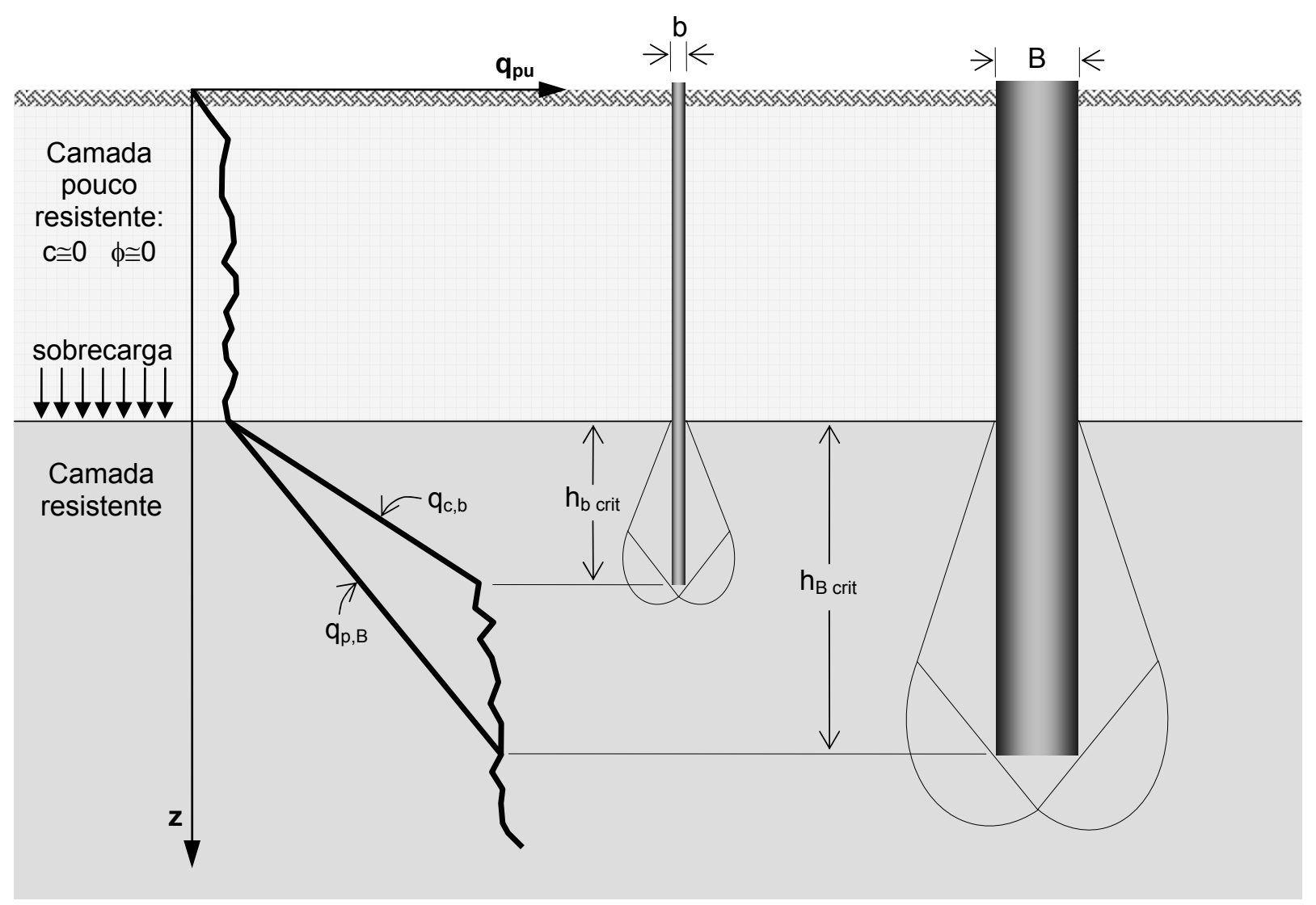

Figura 2.5 - Efeito de embutimento (De BEER, apud SILVA, 2001)

Para estimar a resistência de ponta de estacas a partir dos dados do CPT, é necessário fazer a “correção" deste efeito através da expressão:

$$
h_{B, c r i t}=h_{b, c r i t} \cdot \frac{B}{b}
$$

Décourt (1996) questiona o efeito de embutimento, baseado nas experiências de Briaud e Jeanjean (1994) e em resultados de ensaios feitos no campo experimental da Unesp Bauru. 
Como alternativa, propõe a utilização da normalização dos recalques pelo lado da placa e das cargas (ou tensões) pela carga (ou tensão) correspondente à ruptura convencional (DÉCOURT; QUARESMA FILHO, 1996).

\section{4- Teorias de expansão da cavidade}

Vesic' (1975) menciona a inadequação das teorias clássicas para a determinação da resistência de ponta baseadas na teoria da plasticidade como motivo para o desenvolvimento de teorias elastoplásticas lineares ou não lineares mais refinadas.

A primeira formulação de expansão de cavidades foi apresentada por Bishop et al. (1945), conforme mostrado anteriormente (ver Figura 2.3).

As teorias de expansão de cavidades, segundo diversos autores, podem considerar expansão cilíndrica ou expansão esférica. A escolha do modelo mais adequado não é consenso entre os pesquisadores.

Pesquisas de Al-Awquati e Vesic', apud Vesic' (1975) sobre resistência à penetração e capacidade de carga de estacas mostraram que a resistência de ponta não é governada pela tensão vertical de solo, mas pela tensão média ou octaédrica do solo na ponta da estaca $\sigma_{o c t}$, expressa pela equação:

$$
\sigma_{o c t}=\frac{1+2 \cdot K_{0}}{3} \cdot \sigma_{v}
$$

A capacidade de carga pode ser expressa por:

$$
q_{p, u l t}=c \cdot N_{c}^{*}+\sigma_{o c t} \cdot N_{q}^{*}
$$


Onde $N_{c}^{*}$ e $N_{q}^{*}$ são fatores combinados de capacidade de carga e forma. Vesic' menciona, ainda, que o cálculo de $N_{q}^{*}$ pode ser feito por qualquer método que leve em conta, prioritariamente, a deformabilidade do solo, devendo se basear em um padrão de ruptura realístico.

Vesic' afirma que “De acordo com observações em modelos e estacas de tamanho real sempre existe abaixo da ponta da estaca uma cunha de material muito comprimido... Em solos relativamente fofos esta cunha força o caminho através da massa sem produzir outras superfícies de deslizamento visíveis. Contudo, em solos relativamente densos, a cunha empurra lateralmente a zona de cisalhamento radial para dentro da zona plástica III. Então, o avanço da estaca para dentro do solo é possível pela expansão lateral do solo ao longo do anel circular $B D$, com alguma compressão das zonas I e II", como mostra a Figura 2.6.

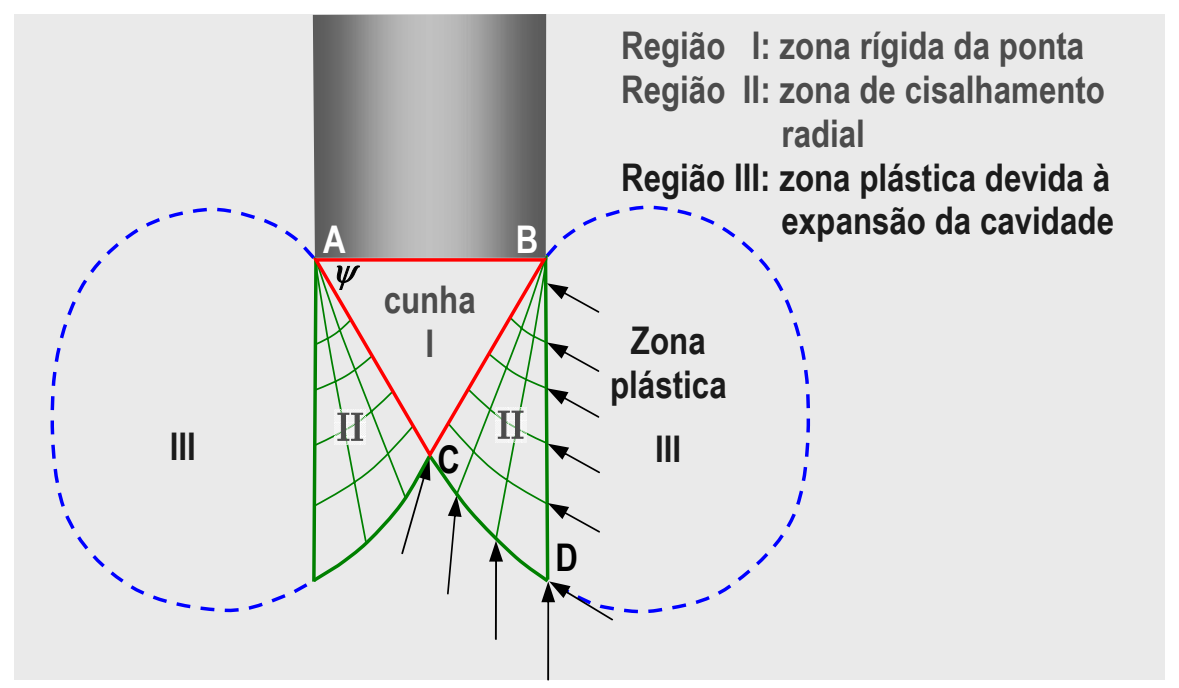

Figura 2.6 - Padrão assumido de ruptura na ponta (VESIC', 1975)

A análise de resultados de provas de carga feita por Vesic' mostrou que as deformações ao redor da ponta das estacas podem ser divididas em duas grandes zonas principais. A zona próxima à ponta é caracterizada por grandes deformações plásticas, enquanto que a zona concêntrica seguinte é caracterizada por pequenas deformações elásticas (Figuras 2.7 e 2.8). 
Vesic' afirma que "Em todas as fotos, o ângulo da base da cunha é aproximadamente igual a $45^{\circ}+\phi / 2$, se $\phi$ é tomado como o ângulo secante para o nível de tensão apropriado. Contudo, os lados da cunha parecem ter uma curvatura côncava, formando uma obtusa e arredondada ponta, em vez de um vértice pontudo".

Vesic' afirma, ainda, que "Baseado nas condições de fronteira ... um valor aproximado de $N_{q}^{*}$ pode ser determinado se assume-se que a tensão normal ao longo do anel $B D$ é igual à pressão última necessária para expandir uma cavidade esférica na massa infinita de solo”.

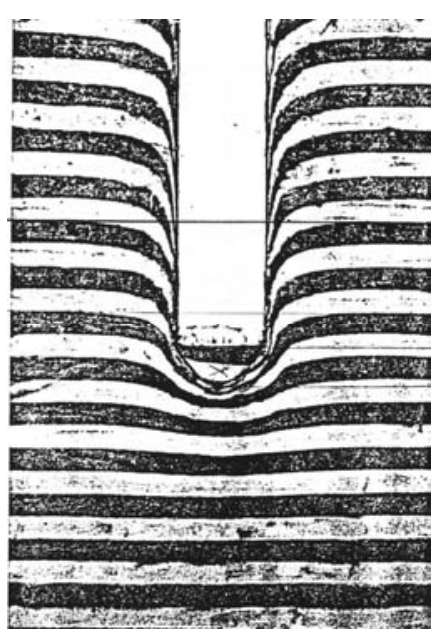

Argila mole (ROURK, 1961)
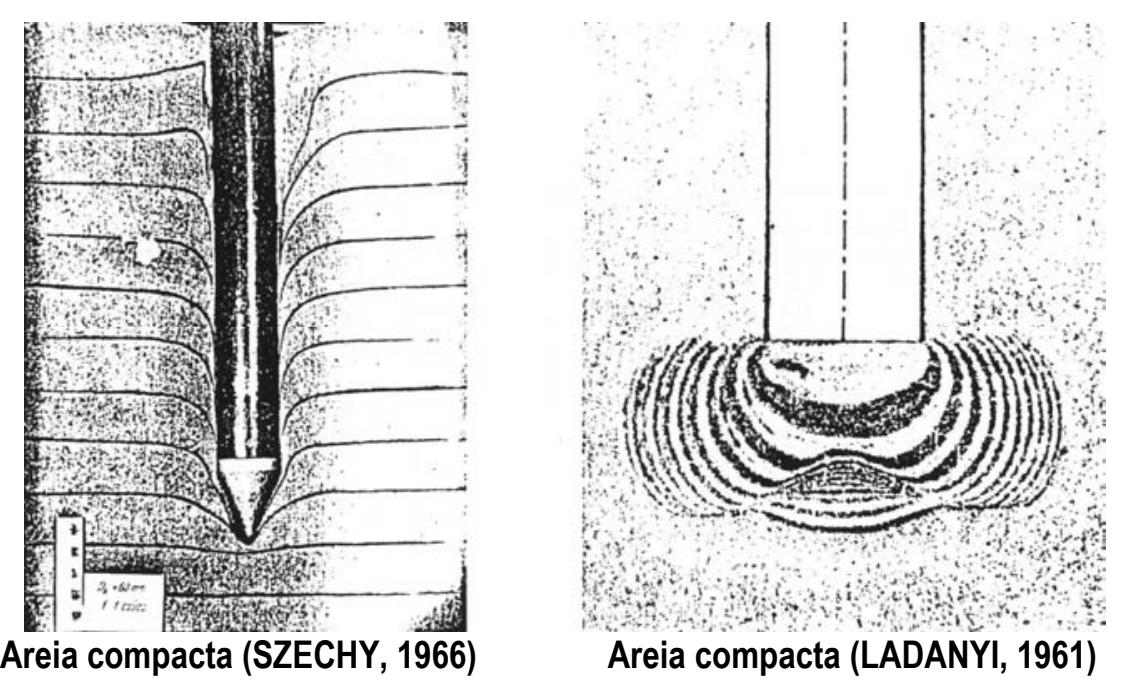

Figura 2.7 - Padrões de ruptura (VESIC', 1975)

O solo é considerando como um material contínuo, uniforme, isotrópico, elastoplástico perfeito e sem variação de volume. 


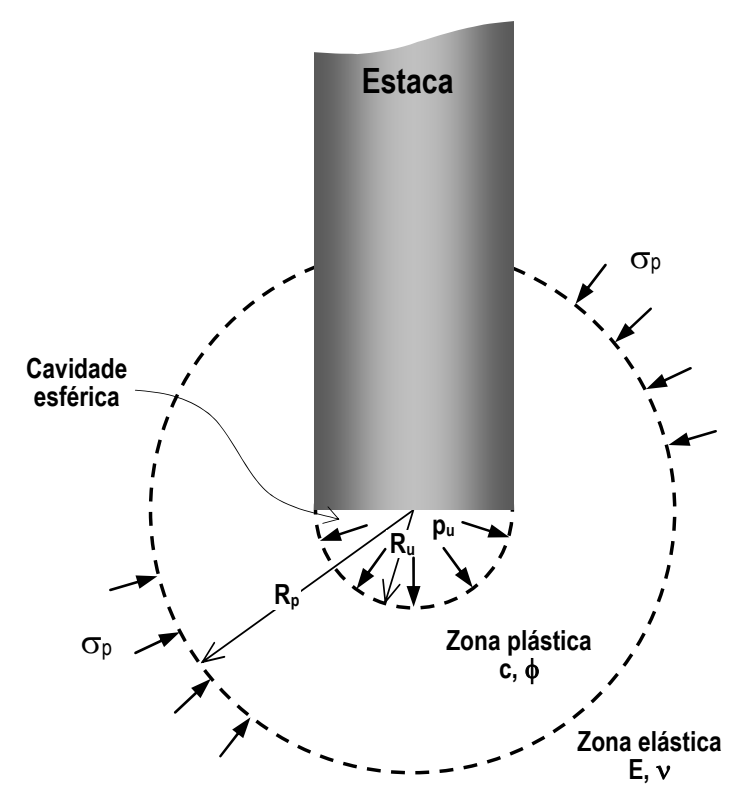

Figura 2.8 - Expansão de cavidade esférica (VESIC, apud SILVA, 2001)

$N_{q}^{*}$ pode ser calculado pela expressão:

$$
N_{q}^{*}=\frac{3}{3-\operatorname{sen} \phi} \cdot e^{\left(\frac{\pi}{2}-\phi\right) \cdot \operatorname{tg} \phi} \cdot \operatorname{tg}^{2}\left(\frac{\pi}{4}+\frac{\phi}{2}\right) \cdot I_{r r} \frac{4 \cdot \operatorname{sen} \phi}{3 \cdot(1+\operatorname{sen} \phi)}
$$

E $I_{r r}$ pode ser calculado por:

$$
I_{r r}=\frac{I_{r}}{1+I_{r} \cdot \Delta}
$$

Para as condições em que não haja variação de volume, seja por condições não drenadas ou por pequenas mudanças de volume em solos densos, o índice de rigidez pode ser expresso por:

$$
I_{r}=\frac{E}{2 \cdot(1+v) \cdot\left(c+\sigma_{o c t} \cdot \operatorname{tg} \phi\right)}
$$


E $N_{c}^{*}$ pode ser calculado por:

$$
N_{c}^{*}=\frac{4}{3} \cdot\left(\ln I_{r r}+1\right)+\frac{\pi}{2}+1
$$

Van Impe (1997) menciona que somente para casos de expansão totalmente não drenada em materiais contínuos abordagens teóricas seguras são utilizáveis. No entanto, para condições drenadas ou parcialmente drenadas, o número de modelos teóricos disponíveis é limitado.

Ainda segundo Van Impe (1991), experimentos feitos por Datta (1982), sob condições parcialmente drenadas em estacas cravadas, mostraram excesso de poro pressão em areias pedregulhosas pelo tempo de até 5 minutos, e pelo tempo de até 45 minutos em areia fina siltosa. O excesso de poro pressão máximo encontrado foi cerca de $20 \%$ da sobrecarga vertical.

Em condições não drenadas, Van Impe, usando o modelo elastoplástico perfeito de Tresca, encontrou concordância com o modelo de Mohr-Coulomb, para um solo totalmente saturado, puramente coesivo $\left(\phi=0^{\circ}\right)$, sob carregamento rápido.

Salgado et al. (1997), pesquisando a resistência de penetração do cone em areias com o uso de câmaras de calibração, apresentaram um modelo mais detalhado de expansão de cavidade (Figura 2.9).

A análise de expansão de cavidade consiste, portanto, em determinar a pressão necessária para expandir uma cavidade em um meio homogêneo, de certa quantia. 


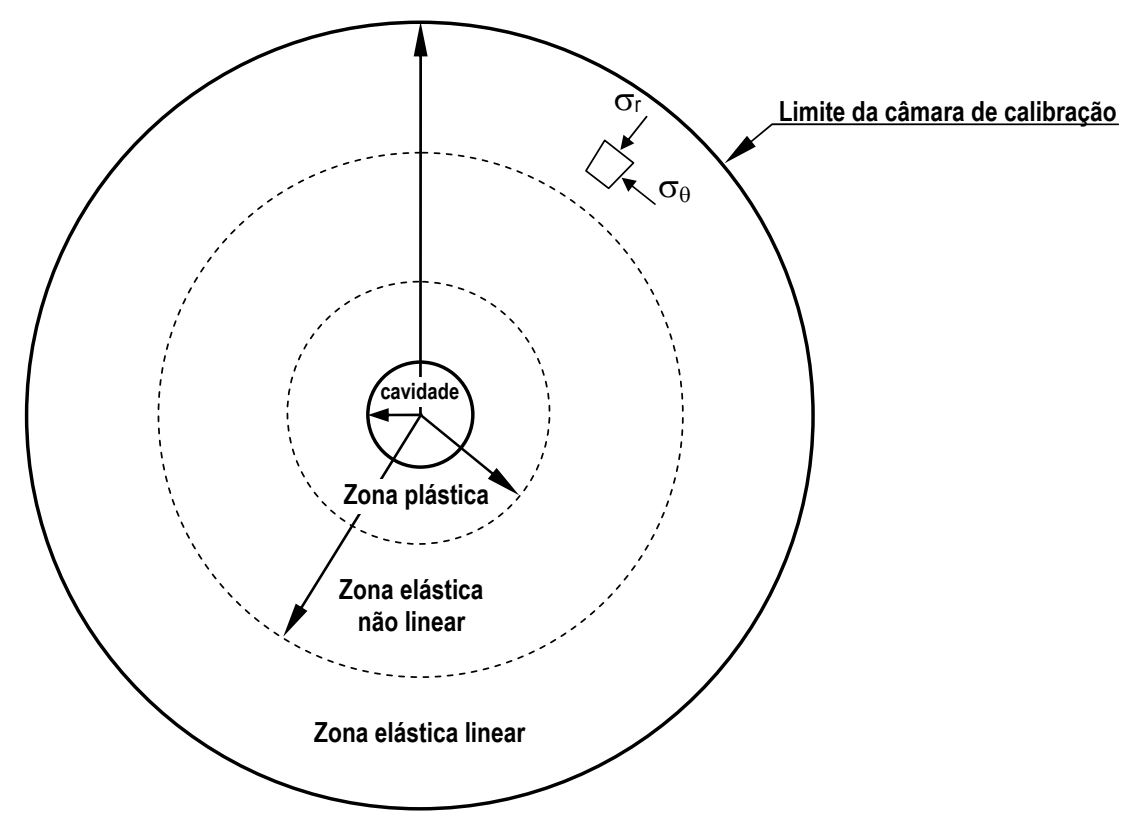

Figura 2.9 - Zonas devidas à expansão de cavidade em ensaios de cone em câmara de calibração (SALGADO et al., 1997)

Existem dois tipos de expansão de cavidade possíveis:

(a) A de uma cavidade pré-existente no solo, com pressão interna equilibrada com o maciço vizinho e que requer acréscimos de pressão para se expandir;

(b) A de uma situação onde inicialmente não existe a cavidade, que deverá ser expandida a partir de um raio igual a zero.

Podem ser feitos analogias destes tipos de expansão de cavidades com os processos de instalação de estacas e suas respectivas resistências de ponta desenvolvidas.

Como alternativa, Baligh (1985), propõe o método de trajetória de deformações, que consiste em uma técnica analítica de predição da perturbação causada pela instalação de objetos rígidos no solo e está baseada na estimativa inicial de incrementos de deformação e do cálculo das tensões necessárias para estas deformações.

Baligh afirma que pode ser uma alternativa de predição mais realista que a teoria de expansão de cavidades para a estimativa dos efeitos de instalação e capacidade de carga de fundações 
profundas, com as possibilidades de estender as soluções para argilas anisotrópicas, estacas rugosas, etc., e de prover técnicas para a determinação da poro pressão causada pela penetração.

Os gráficos que expõe a proposição de Baligh podem ser vistos nas Figuras 2.10 e 2.11.

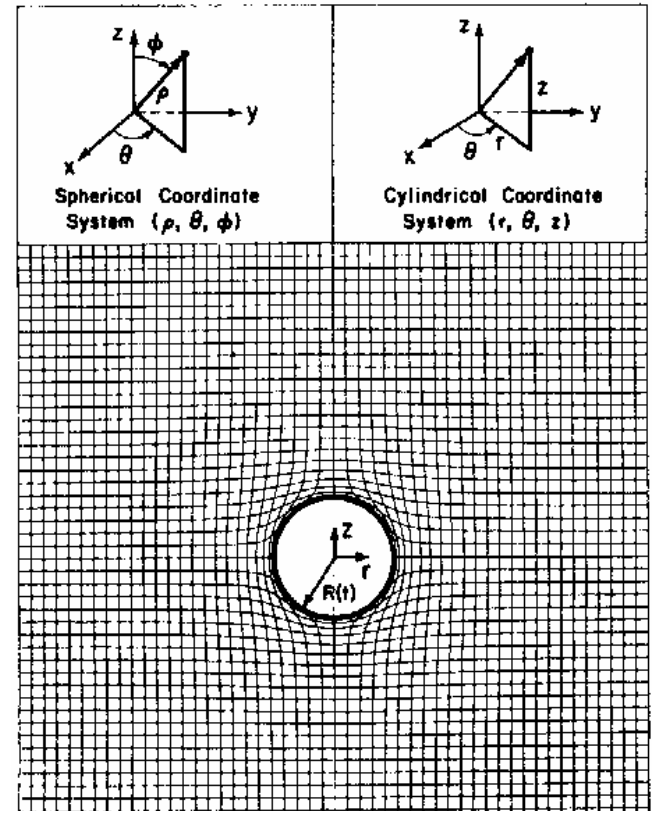

(a) expansão de uma cavidade profunda

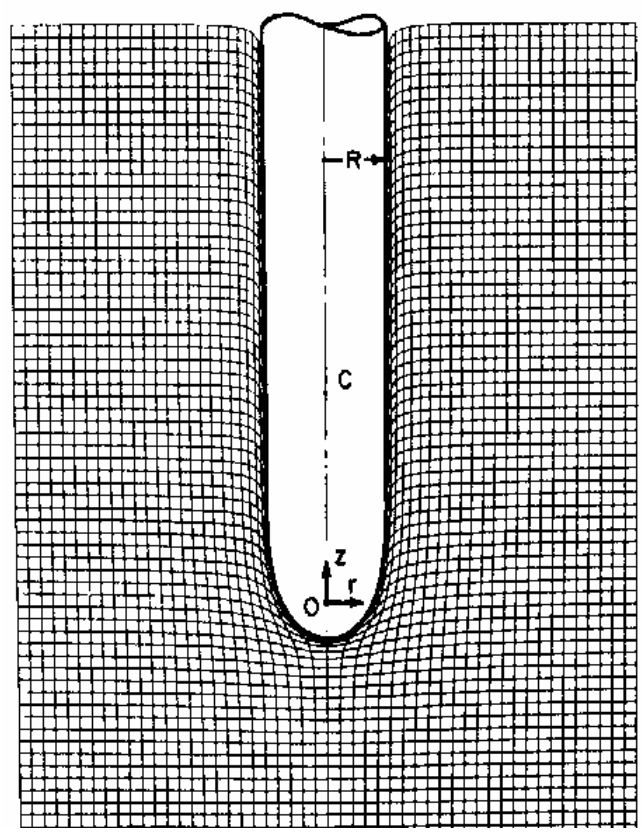

(b) penetração de uma estaca

Figura 2.10 - Deformação da malha em argilas saturadas (BALIGH, 1985) 


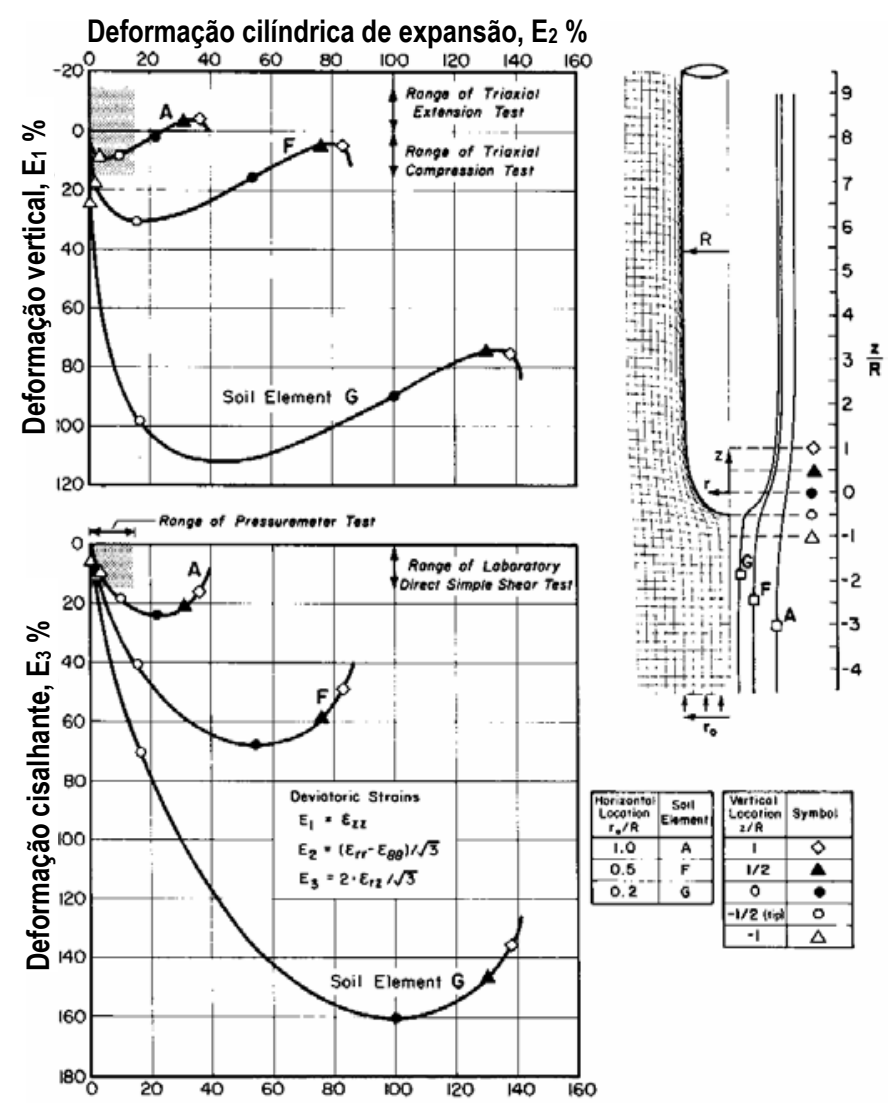

Figura 2.11 - Trajetórias de deformação na penetração de uma estaca (BALIGH, 1985)

\section{5- Estacas de deslocamento}

Estacas de deslocamento são assim designadas porque a sua instalação, geralmente, é feita por cravação de um elemento rígido através do solo, sem remoção de material, provocando o deslocamento do solo que, em geral, melhora as suas características, aumentando a rigidez e a resistência. O elemento a ser cravado, maciço ou não, pode ser pré-fabricado em concreto ou constituído por tubo metálico com ponta fechada e extraído durante a concretagem, feita logo após o término da cravação. O deslocamento do solo pode, ainda, ser feito por ferramenta apropriada, com concretagem na seqüência. Nestes últimos casos, apesar de serem, conceitualmente, estacas de deslocamento, são moldadas in situ. 
As principais vantagens das estacas de deslocamento são as possibilidades de avançar abaixo do nível freático sem necessidade de suporte, além da monitoração da sua cravação, o que permite a intervenção (sua principal vantagem).

A diferença básica entre as estacas de deslocamento e as estacas escavadas está no deslocamento provocado no solo pelas primeiras, interferindo nas características naturais do solo e no seu contato com a estaca, ao longo do fuste e da área da ponta.

\section{6- Estacas escavadas}

Adotaremos a nomenclatura de escavadas para designar as estacas onde há a remoção do solo durante a sua instalação. Em função da sua forma de instalação, estas estacas estão sujeitas a variados graus de redução do confinamento do solo, portanto, com redução da rigidez e da resistência do solo.

São executadas através da abertura de furos, geralmente cilíndricos, com o uso de ferramentas de corte e remoção do material, para posterior concretagem. As ferramentas de corte mais comuns são o trado e a caçamba. A remoção pode ser feita com a própria ferramenta de corte ou, no caso de estacas escavadas com o uso de lama estabilizante, quando há dificuldade na remoção integral dos detritos, com o auxílio de equipamentos especiais, como o air-lift.

As principais vantagens das estacas escavadas são a ausência de vibração, produzir relativamente pouco ruído, evitar cortes e emendas no seu elemento estrutural e o baixo custo.

\section{7- Influências negativas no comportamento de estacas}

As influências negativas tratadas aqui são devidas às mudanças no comportamento do solo pelas perturbações oriundas do método executivo e as decorrentes de alterações no teor de umidade e/ou no grau de saturação. 


\subsection{1- Devidas à execução}

Como as estacas de deslocamento melhoram as características naturais do solo, neste item serão abordadas somente as estacas designadas como escavadas.

Quando a escavação remove o solo, diminui o estado de tensões vertical na cota de apoio e permite o deslocamento do material nessa direção. A introdução do concreto, mais denso que o solo, repõe este alívio de tensões e ainda causa um acréscimo, que deve recomprimir o solo para uma situação próxima do seu estado original de tensões. Para evitar esta alteração no estado de tensões, a concretagem deve ser feita no menor tempo possível, para restringir este deslocamento, com o conseqüente aumento do teor de umidade, quando na presença de água ou lama de estabilização.

A escavação pode provocar a queda e a deposição de material na base da perfuração, caso haja instabilidade das paredes por deficiência de coesão, se houver pressão de água localizada, por exemplo, devida a descontinuidades do terreno ou, ainda, à alternância de camadas de permeabilidade diferentes. Os detritos podem, ainda, se desprender da própria ferramenta de corte. Nestes casos, poderá ocorrer uma redução importante ou total da parcela de resistência de ponta da estaca.

Finalmente, pode haver a segregação do concreto durante o seu lançamento, permitindo a ocorrência de concreto defeituoso e de baixa capacidade de carga (SLIWINSKI, 1979).

\subsection{2- Devidos ao colapso do solo}

Segundo Cintra (1998), solos com alto índice de vazios e baixo teor de umidade, apresentam as características básicas de solos colapsíveis. Eles apresentam rigidez temporária, mantida pela cimentação entre as partículas e por uma determinada pressão de sucção. 
O colapso se manifesta quando este tipo de solo, sob uma determinada tensão, atinge um grau de saturação crítico e ocorre a destruição da estrutura do solo, ou parte dela, pelo enfraquecimento ou dissolução completa dos pontos de cimentação, associado à diminuição da sua pressão de sucção.

O comportamento tensão deformação de um solo colapsível é uma função contínua, quando forem mantidas as suas condições de baixa umidade natural. Quando ocorre um aumento desta umidade, seu comportamento exibe uma descontinuidade marcante, decorrente do colapso (Figura 2.12).

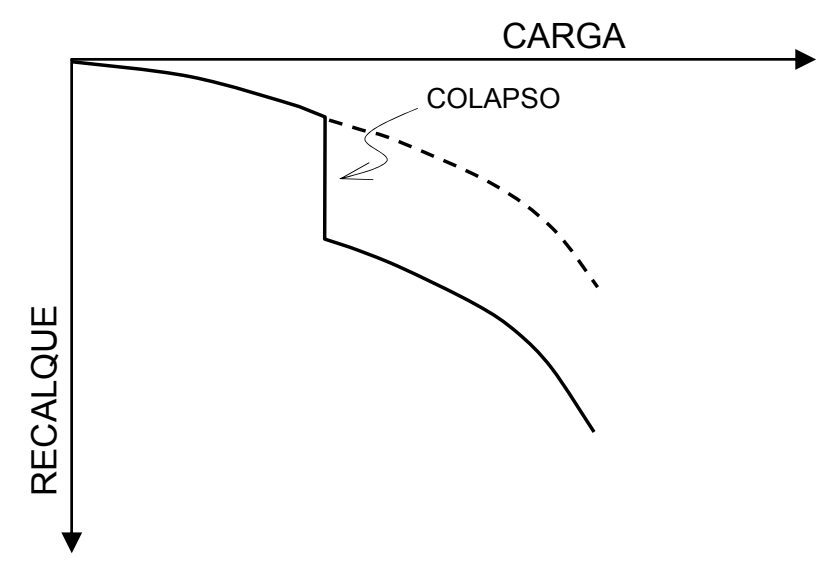

Figura 2.12 - Ocorrência de colapso de um solo sob tensão e com inundação artificial (CINTRA, 1998)

É um recalque brusco, sem variação da tensão aplicada e pode se repetir, caso o solo atinja novamente uma condição de saturação crítica.

O processo de instalação da maioria das estacas escavadas não interfere neste fenômeno, permitindo que ele possa se manifestar, caso ocorram as condições propícias para isto.

No entanto, alguns tipos, como as apiloadas ou as injetadas, podem minimizar este problema, em termos de sua utilização em serviço, porque a sua execução altera as condições do solo junto ao elemento estrutural. 


\subsection{3- Devidas à variação da sucção}

Variações na precipitação pluviométrica induzem variações na sucção dos solos, com intensidade e com propagação no tempo dependentes das características geotécnicas deste maciço, como a permeabilidade e o índice de vazios.

O aumento da precipitação provoca um aumento do teor de umidade e uma conseqüente redução da sucção do solo, com enfraquecimento das ligações entre as partículas e uma diminuição proporcional da sua resistência ao cisalhamento.

Isto implica que a capacidade de carga de uma estaca é totalmente dependente da condição de sucção do solo que, por sua vez, é dependente das condições sazonais de precipitação pluviométrica.

Alem disso, estacas escavadas podem alterar estas condições de sucção por diminuição do teor de umidade (estacas a céu aberto, com demora entre a escavação e concretagem) ou por variações do teor de umidade, devidas a utilização de fluidos de escavação e suporte.

\section{8- Transferência das solicitações}

As solicitações impostas pela estrutura são transferidas para o maciço através de um sistema hiperestático. Esta transferência é uma função dependente das diferenças de rigidez entre o material da estaca e os estratos do maciço de solos (Figuras 2.13 e 2.14). Para a mobilização da resistência de ponta de uma estaca é necessário que o atrito lateral tenha sido mobilizado, uma vez que isso ocorre para pequenos deslocamentos, ao contrário da resistência de ponta. 


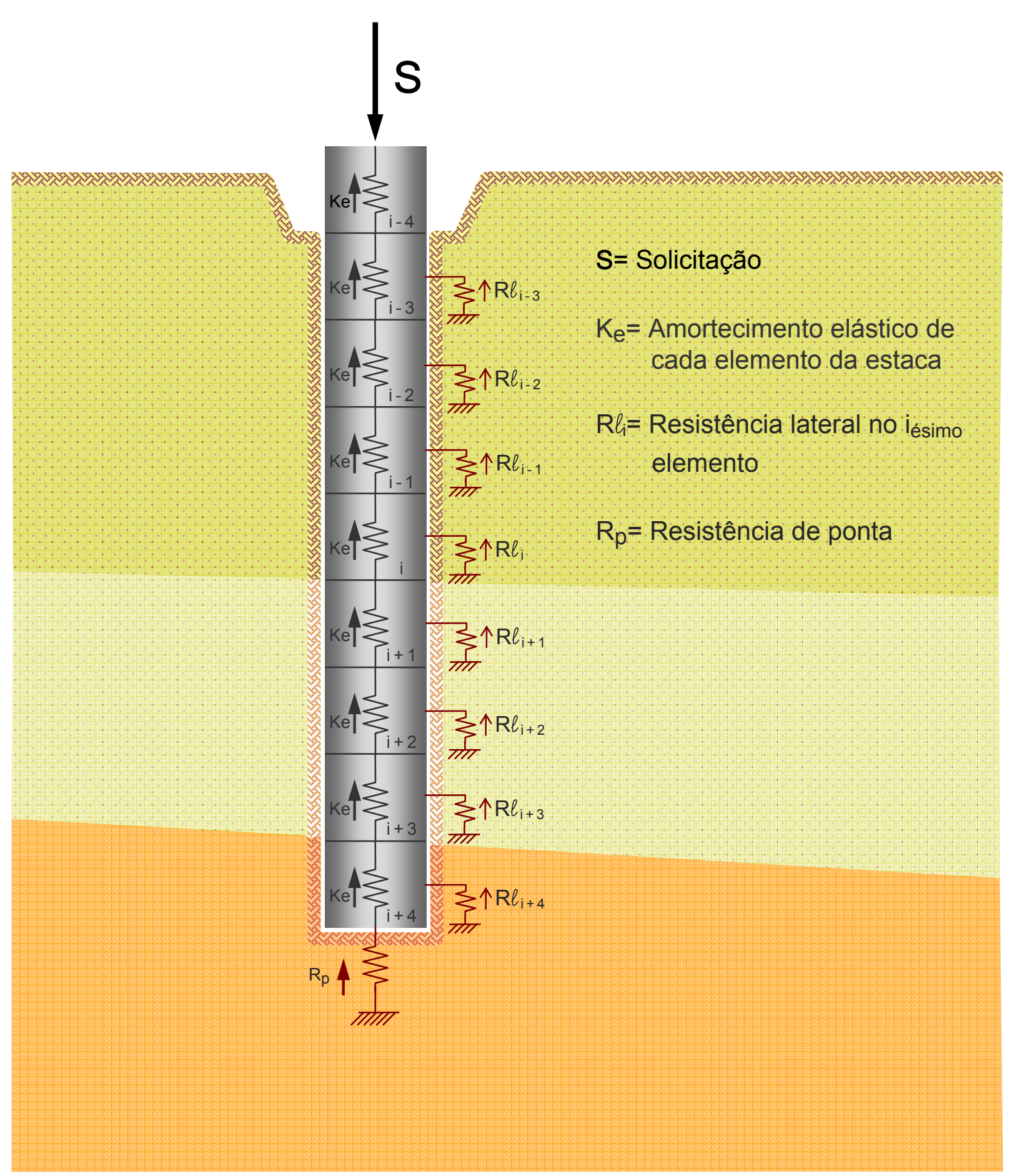

Figura 2.13 - Função de transferência das solicitações em um elemento isolado de fundação (apud VESIC, 1975) 


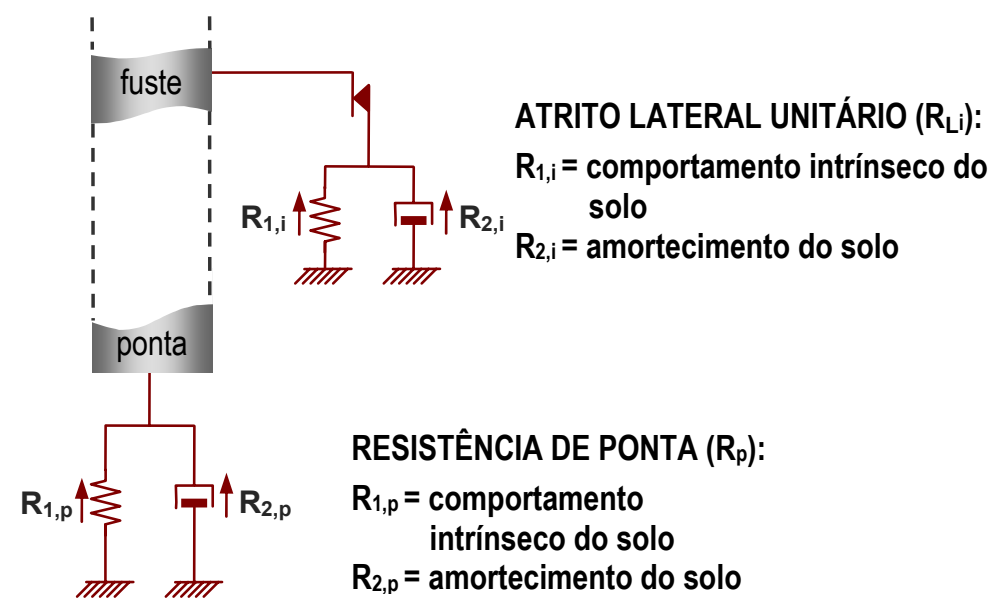

Figura 2.14 - Modelo mais elaborado da função de transferência das parcelas de atrito lateral e resistência de ponta

A transferência não se dá unicamente na interface estaca-solo, mas ao longo de um volume de solo, devido à continuidade do meio, com deslocamentos inversamente proporcionais à distância da interface, até uma superfície tida como indeslocável (Figura 2.15).

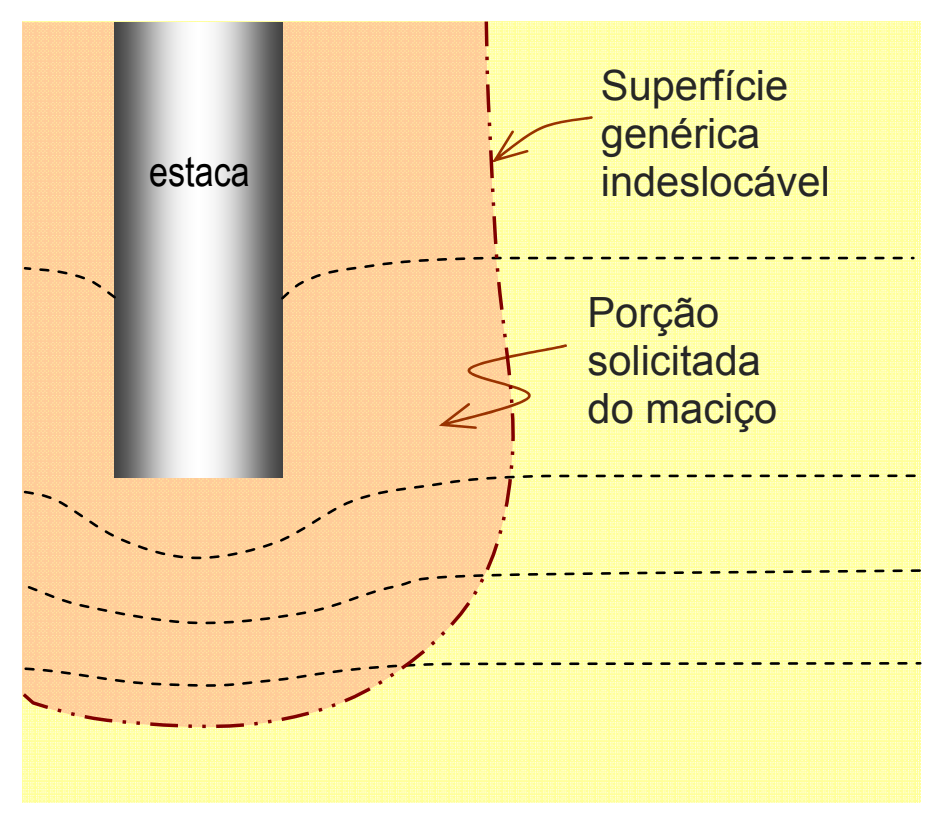

Figura 2.15 - Deslocamentos devidos às parcelas de atrito lateral e resistência de ponta

Os modelos que consideram a continuidade do meio baseiam-se em soluções matemáticas de um meio elástico semi-infinito, isótropo e homogêneo, caracterizado por um módulo de deformabilidade $E_{s}$ e um coeficiente de Poisson $v$. Soluções podem, também, ser obtidas através de elementos finitos. 
Van Weele (1957) propôs um método prático para individualizar as parcelas da capacidade de carga devidas ao atrito lateral e à resistência de ponta através de prova de carga em estaca instrumentada. No seu experimento, foram utilizados quatro strain gauges em profundidades adequadas para permitir a determinação da distribuição das resistências mobilizadas ao longo da estaca e utilizada a técnica de fazer o descarregamento após cada etapa de carga, com a medição do recalque residual (Figura 2.16).

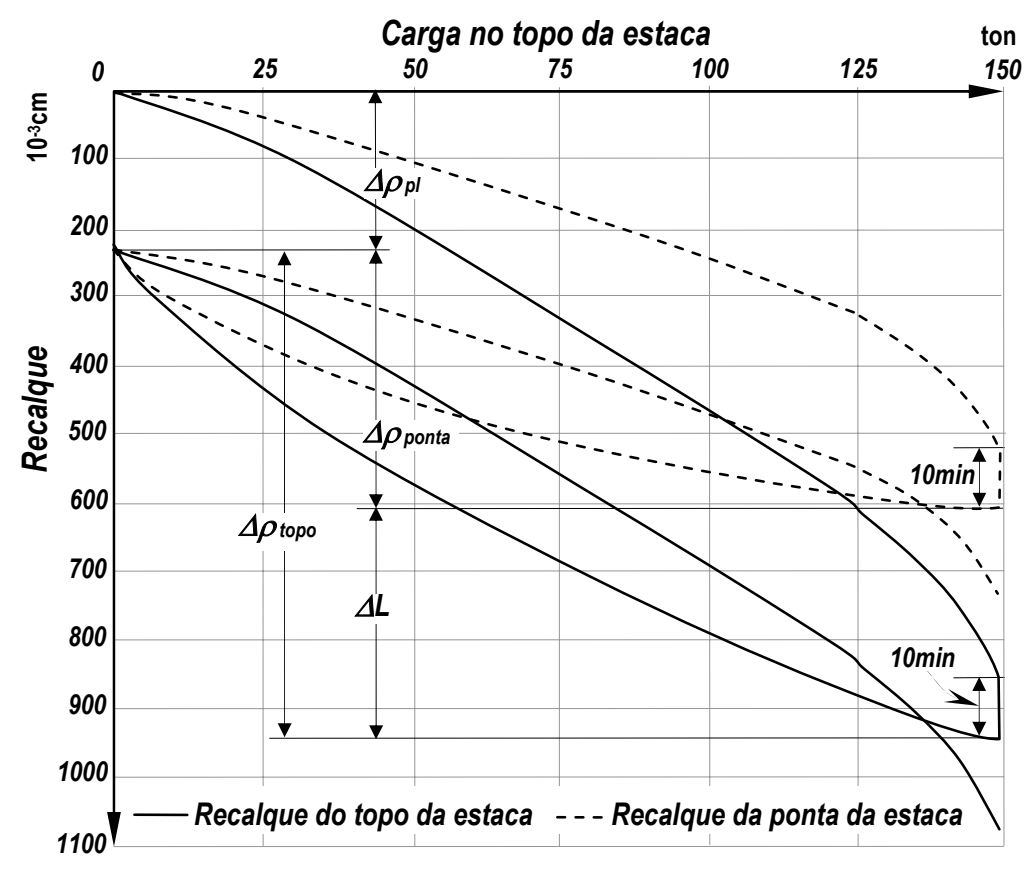

Figura 2.16 - Curvas carga versus recalques de uma estaca instrumentada (Van WEELE, 1957)

Os resultados mostraram que a parcela da resistência de ponta pode ser separada da parcela de atrito lateral, uma vez que a deformação elástica da estaca pode ser deduzida através da interpretação dos dados da instrumentação. No entanto, esta abordagem considera que as alterações que ocorrem no sistema, após cada ciclo de carga, são desprezíveis, o que não condiz com a maioria das situações da prática.

Leonards e Lovell (1979) apresentam proposta de individualização das parcelas de atrito lateral e resistência de ponta baseada no cálculo da deformação elástica da estaca. Van Impe 
et al. (1988) mostram que esta proposta pode apresentar uma variabilidade expressiva, pois é muito influenciada pela variação do diâmetro da estaca.

Franke (1984) propõe a individualização daquelas parcelas através de análises baseadas em estudos de regressão de CPT em solos arenosos e de valores de coesão não drenada $c_{u}$, para solos argilosos.

Outra maneira de individualizar as parcelas de atrito lateral e resistência de ponta é através dos ensaios dinâmicos. Nestes ensaios, a determinação destas parcelas é feita baseada no modelo desenvolvido por Smith (1960), apud Aoki (1997) para solução da equação diferencial da onda unidimensional.

Segundo Aoki, “... capacidade de carga estática oferecida pelo solo, no caso de atrito lateral, é representada pelo valor $R_{s}(m)$...”, conforme ilustrado na Figura 2.17 .

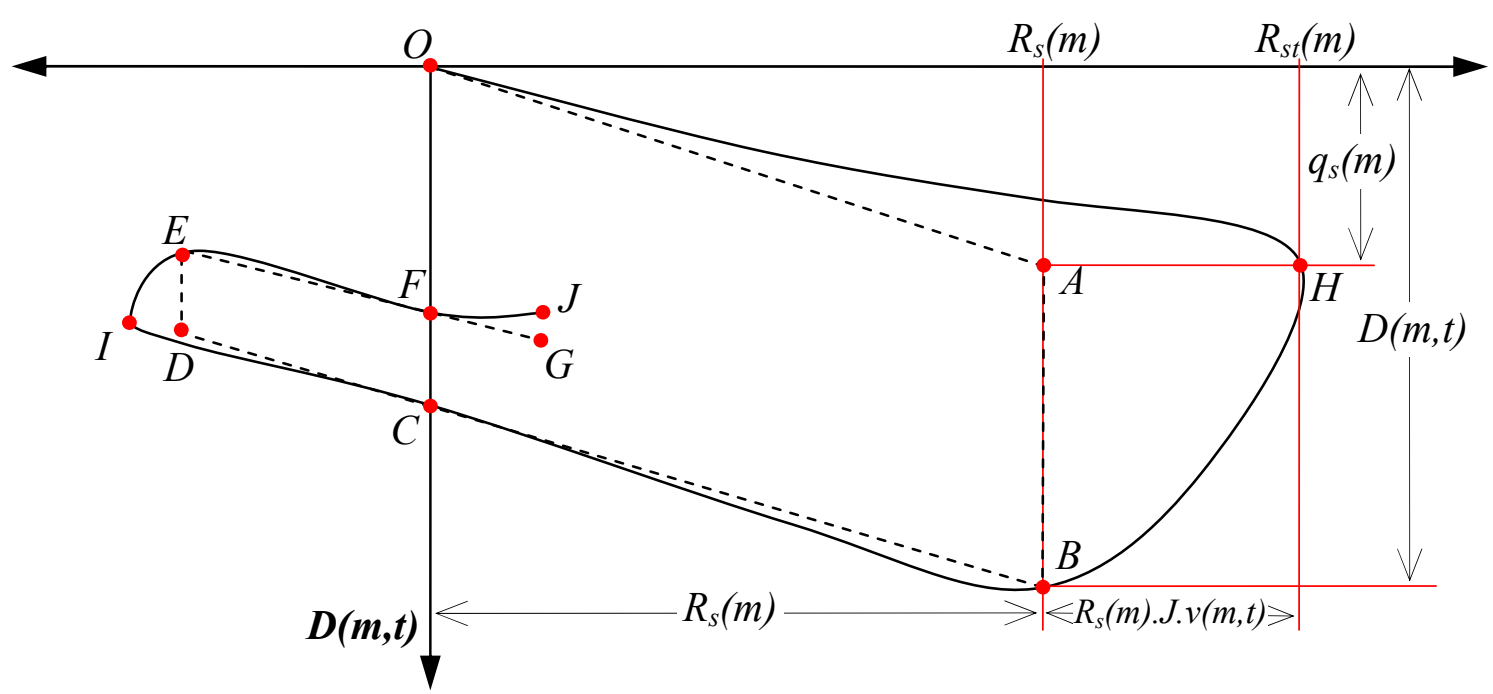

Figura 2.17 - Modelo de Smith para a curva atrito lateral versus deslocamento no ensaio de carregamento dinâmico (apud AOKI, 1997)

"Segundo este modelo, a resistência estática da ponta $R_{p}$ é totalmente mobilizada quando o deslocamento, devido às deformações elásticas do solo sob a ponta da estaca, atinge o valor $C_{3}$ denominado quake de ponta", conforme referência de Aoki (1997) ao modelo de Smith. Esta curva está ilustrada na Figura 2.18. 


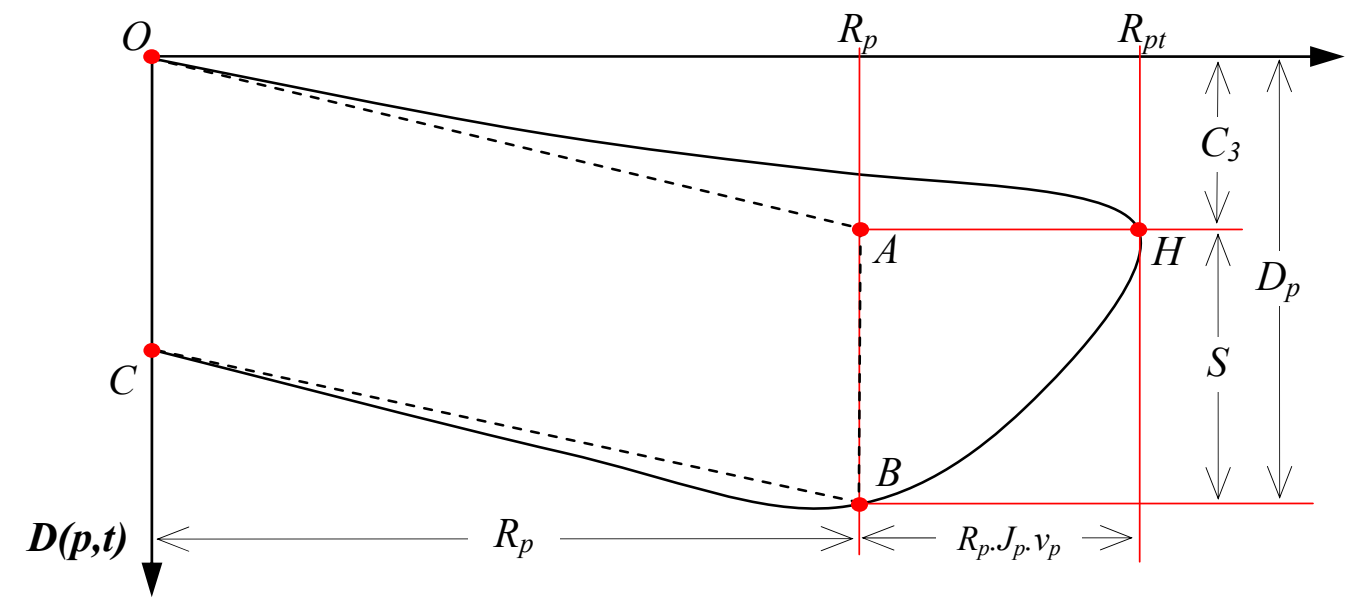

Figura 2.18 - Modelo de Smith (1960) para a curva resistência de ponta versus deslocamento no ensaio de carregamento dinâmico (apud AOKI, 1997)

\section{9- Influência da execução no atrito lateral}

A parcela da capacidade de carga devida ao atrito/adesão lateral corresponderá à resistência ao cisalhamento desenvolvida na interface entre a superfície lateral da estaca e o solo com o qual está em contato. Esta resistência ao cisalhamento dependerá das texturas destes materiais e, principalmente, das características geotécnicas finais do maciço, após a instalação da estaca.

Kraft Jr. (1991), apresenta um resumo dos parâmetros que afetam o comportamento de estacas em areias (Figura 2.19). 


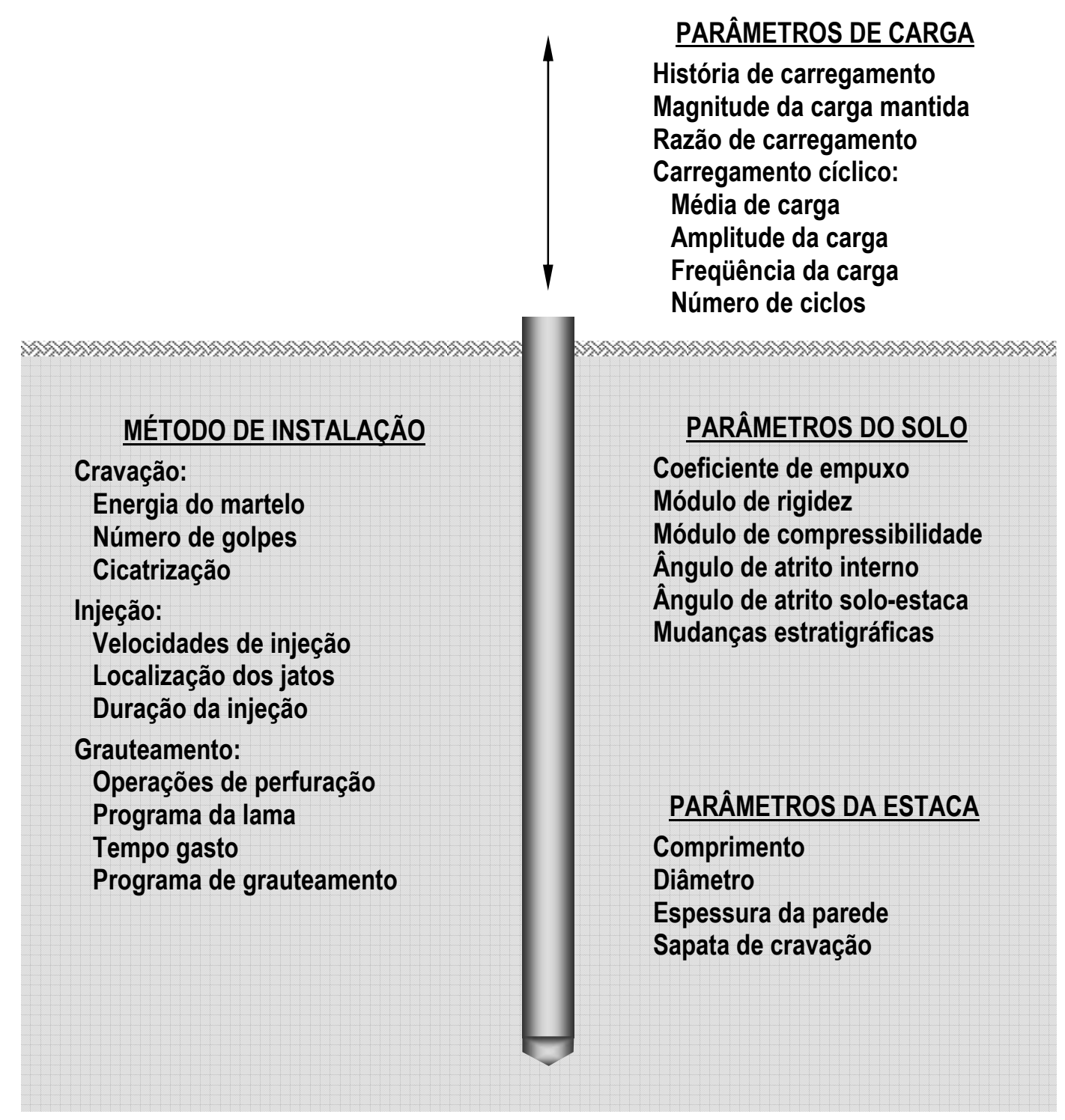

Figura 2.19 - Parâmetros que afetam o comportamento de estacas em areias (KRAFT JR., 1991)

O processo de instalação de estacas perturba a região de contato solo-estaca, podendo:

(a) Alterar o estado de tensões do solo, ao se permitir a relaxação, como é no caso das estacas escavadas, com a deterioração da sua rigidez e resistência;

(b) Alterar o estado de tensões do solo, pelo aumento do confinamento, como é no caso das estacas de deslocamento, com a melhoria das suas rigidez e resistência; 
(c) Alterar a textura natural do solo podendo formar uma superfície de contato estacasolo "menos rugosa" pelo uso de ferramentas ou fluidos de escavação, diminuindo a resistência ao cisalhamento deste contato.

A influência da instalação de estacas no atrito lateral pode ser depreendida observando-se os resultados de CPT da Figura 2.20 (Van WEELE, 1988, apud De BEER, 1988).

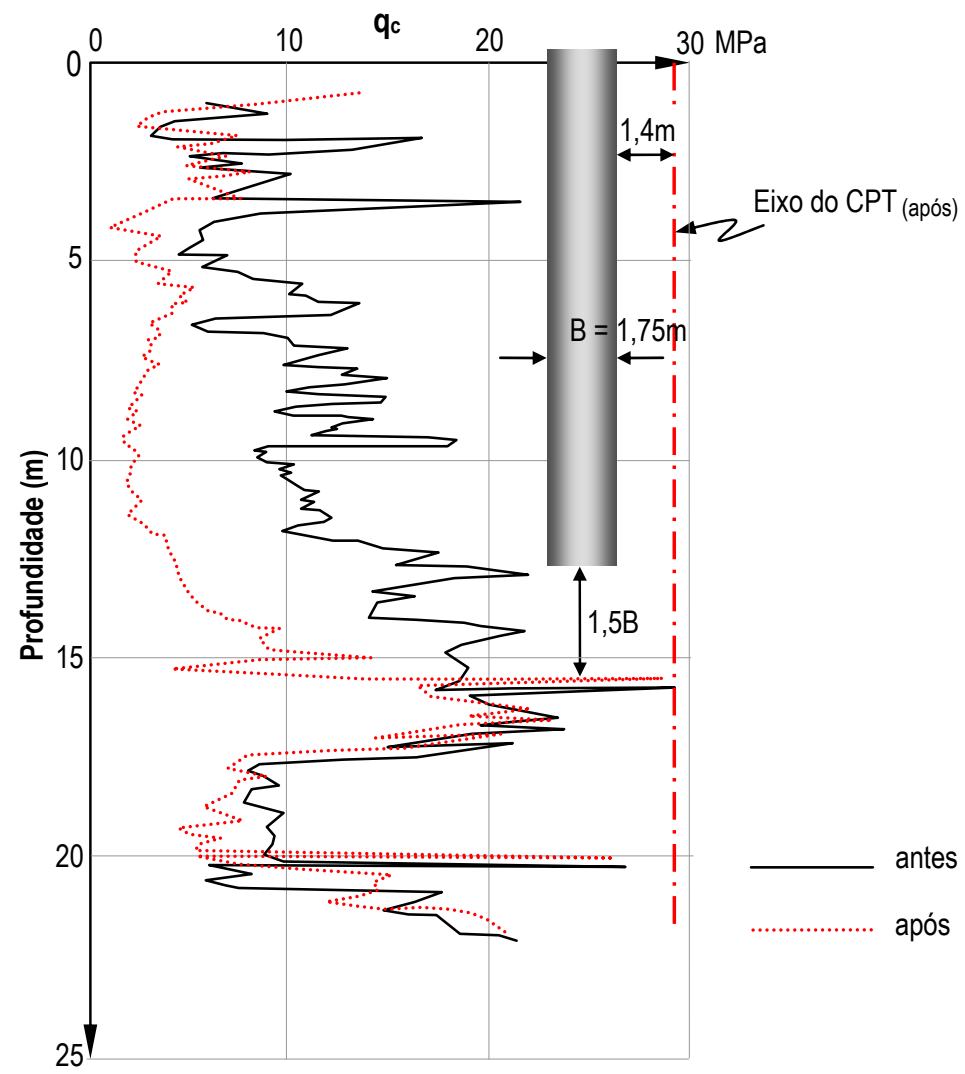

Figura 2.20 - Efeito da instalação (Van WEELE, 1988, apud De BEER, 1988)

Pesquisando a perturbação decorrente da instalação de estacas parafusadas (screw piles), Van Impe \& Peiffer (1997) classificaram estas estacas de acordo com os deslocamentos que provocam e as ordenaram cronologicamente:

(a) Estacas que permitem a escavação de solo durante a instalação, do tipo $C F A$ (Continuous Flight Auger), representando a primeira geração (anos 60); 
(b) Estacas com um significante deslocamento do solo, como as PCS (Pressure Concrete Screw), representando a segunda geração (anos 70);

(c) Estacas com dupla ação de deslocamento, como as Atlas e as Ômega, representando a terceira geração (iniciando nos anos 80).

Conforme o tipo de instalação, as estacas de mesma geometria deverão desenvolver resistências de ponta diferentes. A estes tipos de instalação, os autores sugerem as seguintes analogias (Figura 2.21).
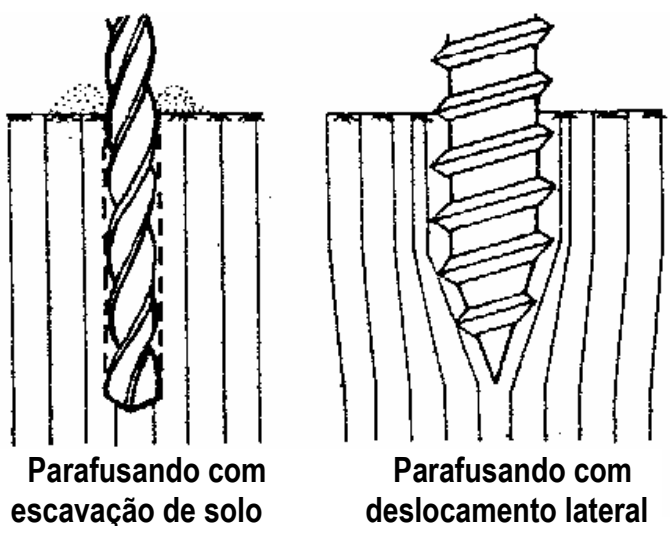

FIGURA 2.21 - Tipos de parafusamento (Van IMPE; PEIFFER, 1997)

As pesquisas de Van Impe e Peiffer foram baseadas na execução de DMTs e objetivaram o estudo do estado de tensões próximo ao fuste de estacas de deslocamento, do tipo screw pile. Suas conclusões mostraram que é importante atentar para a forma da ferramenta de corte, além da disponibilidade de torque do equipamento. Alguns tipos de pontas utilizados são mostrados na Figura 2.22. 


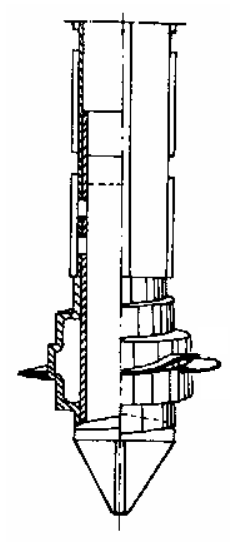

Atlas

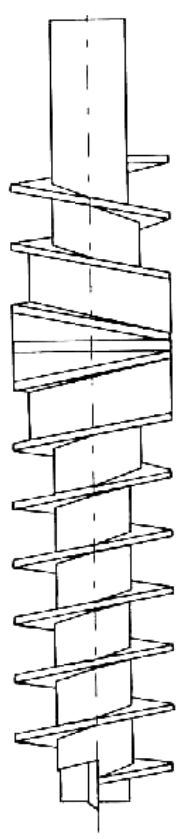

De Waal

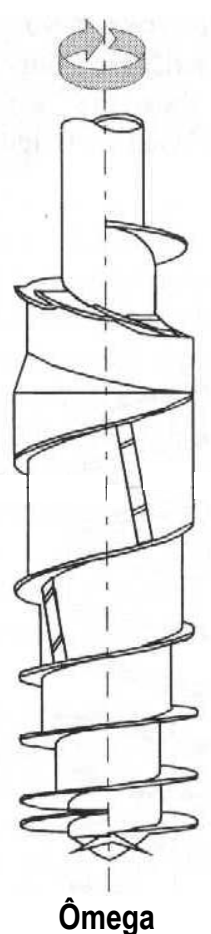

Ômega

Figura 2.22 - Alguns tipos de ponta (Van IMPE; PEIFFER, 1997 e BUSTAMANTE; GIANESELLI, 1998)

$\mathrm{O}$ projeto da ponta do trado deve atender à necessidade de penetrar o maciço, com deslocamento e rapidez.

Para avaliar a influência da instalação de vários tipos de estacas, foram executados DMTs em instantes estratégicos, conforme a Tabela 2.4 .

Tabela 2.4 - Instantes da monitoração da instalação

\begin{tabular}{cccc}
\hline Tipo de estaca & DMT antes & DMT durante & DMT após \\
\hline Omega & $\mathrm{X}$ & $\mathrm{X}$ & $\mathrm{X}$ \\
\hline Atlas & $\mathrm{X}$ & $\mathrm{X}$ & $\mathrm{X}$ \\
\hline Tubular parafusada & $\mathrm{X}$ & $\mathrm{X}$ & $\mathrm{X}$ \\
\hline Coluna de pedregulhos & $\mathrm{X}$ & $\mathrm{X}$ & $\mathrm{X}$ \\
\hline Cravada moldada in situ & $\mathrm{X}$ & $\mathrm{X}$ & \\
\hline
\end{tabular}

A distância de implantação do equipamento foi escolhida de modo que fosse tão próximo que pudesse coletar, de forma realista, os dados da perturbação e à uma distância segura para não 
danificar a sua lâmina. O critério utilizado foi posicionar a lâmina a uma distância menor que o raio plástico previsto pela teoria de expansão de cavidades, o que resultou aproximadamente no diâmetro da estaca.

A execução dos DMT após a instalação das estacas, visou avaliar as mudanças no estado de tensões nas proximidades do fuste.

Os resultados comprovaram um aumento importante da tensão horizontal para as estacas Ômega, um aumento discreto no caso das estacas Atlas e Tubulares Parafusadas, e ligeira diminuição no caso das estacas Pressure Concrete Screw (PCS).

\subsection{0- Influência da execução na resistência de ponta}

Segundo Sliwinski (1979), a resistência de ponta de uma estaca escavada corresponderá à capacidade de carga da camada em que está apoiada, se o método executivo não alterar o estado natural desta camada e se o furo puder ser preenchido com concreto sadio e garantindo um perfeito contato em toda a área da ponta.

Nos materiais não coesivos, como as areias, a ferramenta de corte utilizada é, geralmente uma caçamba, e pode haver redução pronunciada da compacidade na ponta, devida a três fatores principais:

(a) Redução do confinamento na cota da escavação;

(b) Formação de gradientes hidráulicos, em função das oscilações do nível d'água dentro da escavação, durante as manobras verticais da caçamba;

(c) Efeito de êmbolo (sucção) causado pela subida rápida da caçamba. 
Nas argilas, as ferramentas de corte geralmente utilizadas são o trado, para escavações a seco e a caçamba, para escavações abaixo do nível freático.

Também pode haver redução pronunciada da resistência de ponta, devida a três fatores principais:

(a) Redução do confinamento na cota da escavação, com alívio no estado de tensões e as conseqüentes alterações na estrutura e no teor de umidade do solo nesta cota;

(b) Formação de gradientes hidráulicos, em função das oscilações do nível d'água dentro da escavação, durante as manobras verticais da caçamba;

(c) Efeito de êmbolo (sucção) causado pela subida rápida do trado ou da caçamba.

Evidentemente, em ambos os casos, estes fatores podem estar combinados, somando seus efeitos individuais.

Para evitar ou minimizar estes efeitos, devem ser tomadas as seguintes precauções:

(a) A concretagem deve ocorrer no menor intervalo de tempo possível após a escavação;

(b) O nível de água ou de lama bentonítica dentro da escavação deve ser mantido, de preferência, acima do nível freático do terreno;

(c) As manobras verticais do trado e da caçamba devem ser feitas em velocidade moderada e, se possível, usando-se ferramentas com geometria adequada, para permitir o refluxo lateral de ar ou de água com facilidade.

Assim, para a utilização da capacidade de carga integral de uma estaca (atrito lateral/adesão e resistência de ponta), são necessários os seguintes requisitos: 
(a) Qualquer que seja o método de escavação, a estabilidade do furo deve ser assegurada e o material da camada de apoio deve ser mantido no seu estado natural;

(b) A base do furo precisa estar limpa de qualquer sedimento ou solo remoldado ou solto;

(c) A técnica de concretagem precisa assegurar um concreto de boa qualidade em todo o comprimento da estaca.

A influência da instalação de estacas na resistência de ponta pode ser observada através dos resultados de CPT da Figura 2.20 (Van WEELE, 1988, apud De BEER, 1988). Nota-se que a 1,5 vezes o diâmetro da estaca abaixo da ponta, a influência da instalação não é mais percebida, confirmando os modelos clássicos de distribuição de tensões no solo.

A pesquisa de Van Impe e Peiffer (1997) sobre as mudanças no estado das tensões horizontais provocadas pela instalação de estacas, apesar de não ter posicionado lâminas de $D M T$ na profundidade da ponta das estacas, mostrou que as mudanças devem se refletir na resistência de ponta das estacas e poderão ser estimadas, uma vez que a capacidade de carga pode ser tratada pela teoria de expansão de cavidades.

\subsection{1- Comparação entre estacas com fuste moldado in situ}

Existe uma grande variedade de tipos de estacas, desde as pré-fabricadas (de deslocamento), até as com fuste moldado in situ (de deslocamento ou escavadas) e, como foi visto anteriormente, o processo de instalação de uma estaca constitui-se num importante condicionante no seu comportamento futuro (Van IMPE; PEIFFER, SKOV, METS, HEINONEN et al., LEHANE, MANDOLINI, EVERTS; LUGER, SIMONSEN; ATHANASIU, GWIZDALA, MANOLIU, SVENSSSON et al., FINDLAY et al., 1997, GEOFORUM, 2002). 
O processo de instalação das estacas de deslocamento pré-fabricadas geralmente aumenta a rigidez e a resistência do solo, garantindo um bom contato em toda a superfície da ponta e lateral da estaca e apresenta um padrão razoavelmente constante, uma vez que é governada pela geometria da estaca, que é bastante uniforme.

No caso das estacas de deslocamento com fuste moldado in situ, o processo de instalação também aumenta a rigidez e a resistência do solo, mas, dependendo do tipo de estaca, o contato e a melhoria do solo podem apresentar maior variabilidade que as anteriores, em função da variação do nível das tensões horizontais impostas durante a instalação e da geometria resultante.

Estacas escavadas são utilizadas desde meados do século XX. Segundo relato em Geoforum (2002), “Com o desenvolvimento durante os anos 1950 e 60 de perfuratrizes compactas, consistindo em plataforma, guincho e oscilador de revestimento, a técnica de escavação de caçamba foi levada à forma que ainda está em uso hoje”.

Outro desenvolvimento foi a técnica de perfuração rotativa com circulação de lama, que era principalmente usado para furos relativamente fundos (por exemplo, poços de petróleo), devido à complexidade da instalação local. Nos E.U.A., onde antigamente técnicas de circulação de lama na tecnologia de perfuração de poços de petróleo eram de grande importância, foram desenvolvidos equipamentos de perfuração rotativa montados em caminhões e guindastes sobre esteiras. Uma haste de forma quadrada, denominada haste Kelly, suspensa em um guincho de cabo e guiada pela plataforma giratória, tornou possível a perfuração em solos estáveis e rochas, com altas taxas de produção. Depois de Segunda Guerra Mundial, o problema de escavar sem revestimento de furos foi resolvido usando fluidos de suporte, como lamas bentoníticas e aditivos químicos. Esta técnica foi aceita amplamente na Europa, durante os anos 1960. 
Recentemente, o método de perfuração rotativa, particularmente para a instalação de furos de grande diâmetro, evoluiu significativamente pela invenção da transmissão rotativa, montada em um trenó que permite movimento ao longo do mastro rígido da haste de perfuração. Devido aos desenvolvimentos mais recentes no campo de sistemas hidráulicos e eletrônicos, as perfuratrizes atuais são projetadas e fabricadas para alcançar máxima produtividade, com o mínimo de consumo de energia e do uso de força humana.

Tomlinson (1977) apresenta uma relação das vantagens e desvantagens das estacas escavadas.

\section{Vantagens:}

1. Comprimento pode ser prontamente alterado para se adequar às condições variadas do terreno;

2. O solo e/ou a rocha removidos durante a escavação podem ser inspecionados para comparação com os dados da investigação de campo.

3. Podem ser feitos ensaios in situ em furos de grandes diâmetros, ou ensaios de penetração em furos pequenos.

4. Bases muito largas (diâmetros até 7,3 m) podem ser executadas em terreno favorável.

5. As ferramentas de corte podem remover matacões ou outras obstruções que não poderiam ser penetradas por qualquer tipo de estaca de deslocamento.

6. Material da estaca não é dependente do manuseio ou dos esforços motrizes.

7. Pode ser instalada em comprimentos muito longos;

8. Pode ser instalada sem barulho ou vibração apreciáveis;

9. Nenhum risco de levantamento do terreno. 
10. Pode ser instalada em condições de pé direito muito pequeno.

\section{Desvantagens:}

1. O concreto no fuste é suscetível a estreitamento ou estrangulamento (necking) em solos moles, quando equipamentos convencionais são usados.

2. Necessita técnicas especiais para concretagem em solos submersos.

3. Concreto não pode ser inspecionado após a instalação.

4. Bases alargadas não podem ser formadas em materiais puramente granulares.

5. Não pode ser instalada abaixo do nível freático sem cuidado especial.

6. Baixas resistências de ponta em solos granulares podem ser causadas pelas operações convencionais de escavação.

7. A instalação de estacas em grupo pode causar perda de terreno e deslocamentos em estruturas adjacentes.

O tipo mais econômico de estaca escavada é aquele que não necessita de revestimento algum, como a escavada com trado mecânico, mas só deve ser utilizado em solos razoavelmente coesivos e firmes, acima do nível freático.

As estacas escavadas são as que apresentam maiores perturbações no sentido da degradação das condições iniciais do maciço, podendo resultar em consideráveis reduções na rigidez e resistência do solo.

As contribuições relativas do atrito/adesão lateral e da resistência de ponta na capacidade de carga total podem ser significativamente influenciadas pela execução. Vesic' (1975) mostrou 
como a execução pode alterar o estado de tensões no solo e influir no comportamento da estaca (Figura 2.23).

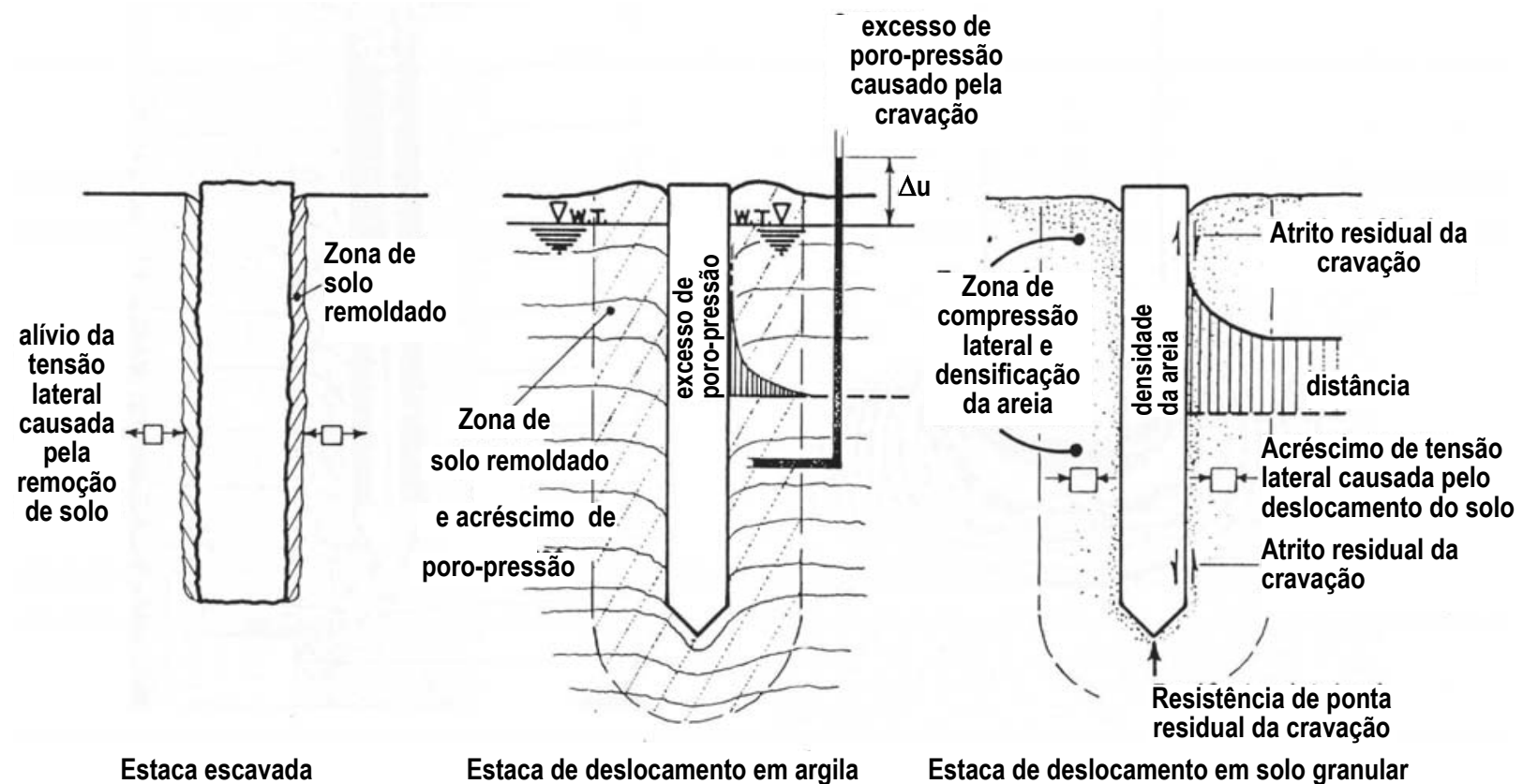

Figura 2.23 - Efeitos da execução no estado de tensões do solo e sua influência no comportamento de estacas (VESIC', 1975)

Neste capítulo, serão abordadas aquelas com fuste moldado in situ, quer sejam de deslocamento ou escavadas, para evidenciar os efeitos das diversas técnicas de instalação na resistência de ponta.

Não é simples separar exatamente as estacas de deslocamento com fuste moldado in situ das escavadas, pois continuamente surgem novos tipos de estacas, e o entendimento do seu comportamento depende de investigações específicas. Assim, entende-se que a descrição sumária dos processos executivos mais comumente utilizados no Brasil, na atualidade, e as respectivas análises das perturbações resultantes possam auxiliar nesta tarefa.

\subsection{1- Estacas Strauss}

Inicia-se o furo com o uso do soquete, até a profundidade necessária para a instalação da coroa (tubo de 3,0 m de comprimento com dentes na ponta). Instalada a coroa, o avanço do 
furo é feito com o uso da sonda (ou piteira) por dentro do revestimento, retirando-se o solo. $\mathrm{O}$ revestimento avança à medida que o furo também avança, evitando deixar solo sem suporte (Figura 2.24).
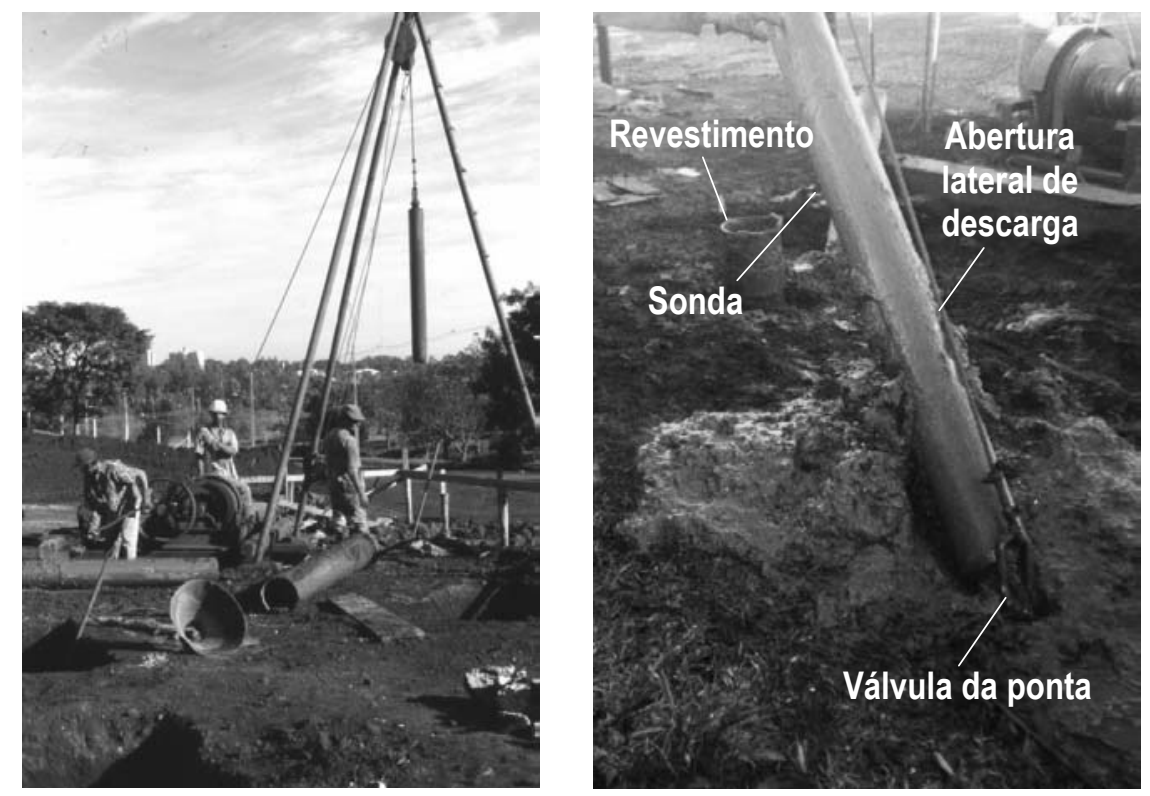

Figura 2.24 - Estacas Strauss - Vista geral e detalhe

Os diâmetros nominais só são atingidos se forem usadas as ferramentas e o método executivo completo, com o uso de tubos de revestimento ao longo de toda a profundidade. Os diâmetros, em centímetros, das ferramentas de corte e de apiloamento e dos tubos de revestimento utilizados são mostradas na Tabela 2.5 (ABEF, 1999).

Tabela 2.5 - Diâmetros dos revestimentos e das ferramentas de estacas do tipo Strauss (ABEF, 1999)

\begin{tabular}{ccccc}
\hline$\phi$ nominal da estaca & $\begin{array}{c}\phi \text { externo do } \\
\text { revestimento }\end{array}$ & $\phi$ externo da coroa & $\phi$ sonda & $\phi$ soquete \\
\hline 25 & 22 & 24 & 17 & 15 \\
\hline 32 & 27 & 29 & 22 & 20 \\
\hline 38 & 32 & 34 & 27 & 25 \\
\hline 42 & 35 & 37 & 32 & 30 \\
\hline 45 & 40 & 42 & 35 & 33 \\
\hline
\end{tabular}

Como pode ser observado, deve haver folga entre as ferramentas e o tubo de revestimento para permitir as manobras. 
São coletadas amostras ao longo da escavação e comparadas com a sondagem mais próxima, como controle. Ao final da escavação, o concreto é lançado, formando uma coluna de, pelo menos, 1,0 m dentro do revestimento. O concreto é apiloado, sem levantar o tubo, para formar a base da estaca. A seguir, é lançado mais concreto, formando uma coluna dentro do revestimento, subindo lentamente o revestimento e adensando o concreto com o pilão. Repete-se a operação até a conclusão da estaca.

As principais vantagens deste tipo de estaca são a baixíssima vibração, a simplicidade e a rusticidade do equipamento, a garantia de um diâmetro mínimo, a ausência de contaminação do concreto com solo e o solo na base da perfuração, apesar de sofrer alguma redução no confinamento (mais sensível nas areias), pode ter sua condição natural recomposta ou até melhorada, em função da compactação usada na formação da base. No entanto, a produção diária média é baixa, da ordem de 30 metros.

\subsection{2- Estacas Apiloadas}

Estacas apiloadas são feitas em solos com $\mathrm{N}_{\mathrm{SPT}}$ até 10, com o mesmo equipamento das estacas Strauss, mas sem o uso do revestimento e da sonda. O furo avança através da percussão do pilão no solo, geralmente com a adição de água, para servir como um agente lubrificante e diminuir a sua resistência. A concretagem é iniciada logo após o final da escavação, sem apiloamento, para evitar o desmoronamento da parede e a contaminação do concreto.

Atenção especial deve ser dada para os diâmetros nominais das estacas e para os dos soquetes utilizados, para garantir as dimensões de projeto (ver Tabela 2.5).

Este tipo de estaca reúne algumas vantagens da estaca Strauss, como a simplicidade e a rusticidade do equipamento e proporciona, ainda, a densificação do solo nas proximidades do fuste, reduzindo a suscetibilidade futura de colapso do solo por possível aumento do teor de 
umidade o. No entanto, o diâmetro é função do diâmetro do soquete e não há garantias quanto à contaminação do concreto com solo. Só deve ser utilizada em solo francamente coesivo e, mesmo assim, evitando-se o apiloamento do concreto. A sua execução apresenta-se com produção média bem superior à das estacas Strauss, atingindo cerca de 120 metros por dia.

\subsection{3- Estacas Franki}

Inicialmente o tubo de revestimento é posicionado verticalmente no eixo da estaca e feita uma bucha, no seu interior, com areia e brita $\mathrm{n}^{\mathrm{o}} 2$, para garantir a estanqueidade e promover a sua cravação (Figura 2.25).

A seguir, o tubo é cravado, verificando-se eventuais levantamentos de estacas vizinhas. Durante a cravação do tubo deve ser observada a sua nega, que deve indicar a proximidade da cota de apoio. Ao atingir a cota de apoio, é feita a verificação da nega através da medida da menor das penetrações de dez golpes com o pilão caindo de $1,0 \mathrm{~m}$ e um golpe com o pilão caindo de 5,0 m (ABEF, 1999). Os resultados devem ser confrontados com a nega de projeto, para determinar o término da cravação.

O tubo, então, é levantado ligeiramente e mantido imóvel com os cabos. A bucha é expulsa sob golpes do pilão, cuidando-se para ter, no tubo, uma bucha com comprimento suficiente para garantir a sua estanqueidade. É introduzido concreto aos poucos e apiloado, sem erguer o tubo, para formar a base da estaca.

As características principais das estacas Franki, com suas capacidades e dimensões, podem ser vistas na Tabela 2.6 (ABEF, 1999). 


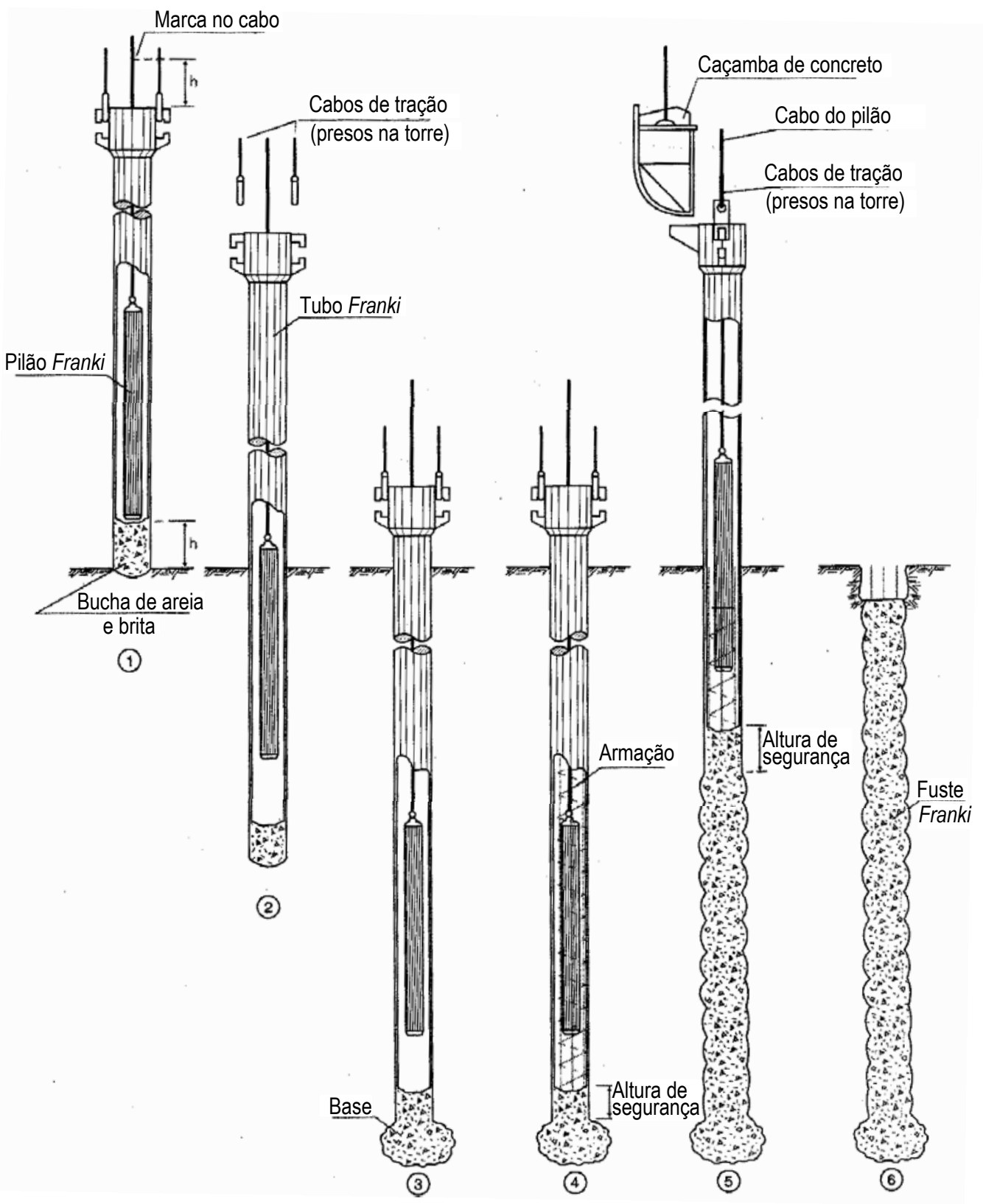

Figura 2.25 - Estacas Franki (ABEF, 1999)

Tabela 2.6 - Características principais das estacas Franki (ABEF, 1999)

\begin{tabular}{ccccc}
\hline $\begin{array}{c}\text { Carga } \\
\text { admissível } \\
\text { da estaca }\end{array}$ & $\begin{array}{c}\phi \text { do } \\
\text { revestimento }\end{array}$ & $\begin{array}{c}\text { Volume } \\
\text { mínimo da } \\
\text { base }\end{array}$ & $\begin{array}{c}\text { Energia/ } \\
90 \mathrm{dm}^{3}\end{array}$ & $\begin{array}{c}\text { Energia/ } \\
150 \mathrm{dm}^{3}\end{array}$ \\
\hline $450 \mathrm{kN}$ & $30 \mathrm{~cm}$ & $90 \mathrm{dm}^{3}$ & $1,5 \mathrm{MNm}$ & $2,5 \mathrm{MNm}$ \\
\hline $550 \mathrm{kN}$ & $35 \mathrm{~cm}$ & $90 \mathrm{dm}^{3}$ & $1,5 \mathrm{MNm}$ & $2,5 \mathrm{MNm}$ \\
\hline $800 \mathrm{kN}$ & $40 \mathrm{~cm}$ & $180 \mathrm{dm}^{3}$ & $1,5 \mathrm{MNm}$ & $2,5 \mathrm{MNm}$ \\
\hline $1300 \mathrm{kN}$ & $52 \mathrm{~cm}$ & $300 \mathrm{dm}^{3}$ & $3,0 \mathrm{MNm}$ & $5,0 \mathrm{MNm}$ \\
\hline $1700 \mathrm{kN}$ & $60 \mathrm{~cm}$ & $450 \mathrm{dm}^{3}$ & $3,0 \mathrm{MNm}$ & $5,0 \mathrm{MNm}$ \\
\hline
\end{tabular}


A armadura é introduzida e iniciada a concretagem com o apiloamento do concreto no fuste em camadas sucessivas enquanto se retira o tubo. Cuidado especial deve ser dado para que seja garantida uma altura mínima de concreto, através da observação de uma marca no cabo do pilão, em relação ao tubo. A estaca é concluída com a retirada integral do tubo de revestimento e com o concreto pelo menos 30 centímetros acima da cota de arrasamento.

As principais vantagens estão relacionadas às vantagens das estacas pré-moldadas, com as vantagens da ausência de emendas ou cortes, a possibilidade da formação da base de área maior que a do fuste e permitir o apoio da ponta em estratos profundos mais resistentes. No entanto, apresenta as desvantagens principais da vibração excessiva e baixa produção diária média, da ordem de 30 metros.

\subsection{4- Estacas Escavadas de Pequeno Diâmetro (com trado mecânico)}

O trado é posicionado no eixo da estaca e iniciado a perfuração, através de processo rotativo. A escavação prossegue com a descida do trado, escavação, subida com o solo entre as pás do trado e descarga na superfície, por rotação rápida do trado. O solo solto na superfície deve ser constantemente removido da boca do furo por um auxiliar, com enxada (Figura 2.26). 


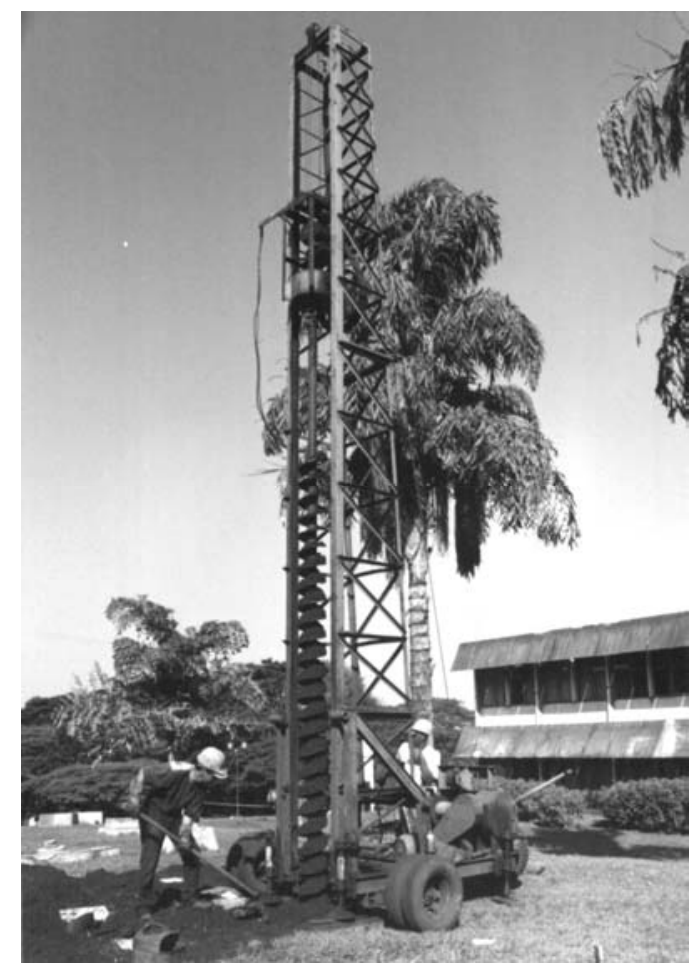

Figura 2.26 - Estacas escavadas com trado mecânico

O material escavado é constantemente comparado com os obtidos pela sondagem, para confirmação da cota de apoio. Esta comparação deve ser feita tanto em termos das características visuais do material, como pela dificuldade de escavação observada pelo operador. Após a perfuração, caso haja a necessidade de armadura, esta deve ser introduzida com o devido cuidado para não desprender solo das paredes da escavação e a concretagem tem início, com o uso de funil.

As principais vantagens são a ausência de vibração, a garantia da geometria imposta pelo trado e o baixo custo, associadas à alta produtividade. No entanto, as ferramentas de perfuração tradicionais não conseguem remover todo o material escavado, gerando solo solto na base da perfuração, além da perturbação própria da escavação, com remoldamento e redução do confinamento natural do solo. A produção diária média é da ordem de 120 metros. 


\subsection{5- $\quad$ Estacas Escavadas de Grandes Dimensões}

Estacas escavadas de grandes dimensões podem ser de seção circular (estacões), quando utilizam ferramentas de corte como as da Figura 2.27, ou de seção retangular (Barrete), quando utilizam ferramentas de corte, como as da Figura 2.28.

Em Geoforum (2002), na descrição dos processos de instalação de estacas, afirma-se que “...a caçamba possui dentes escarificadores no extremo das aberturas do fundo e penetra no solo, através do seu peso próprio. A inclinação dos dentes também puxa a caçamba para baixo, de acordo com o torque aplicado.

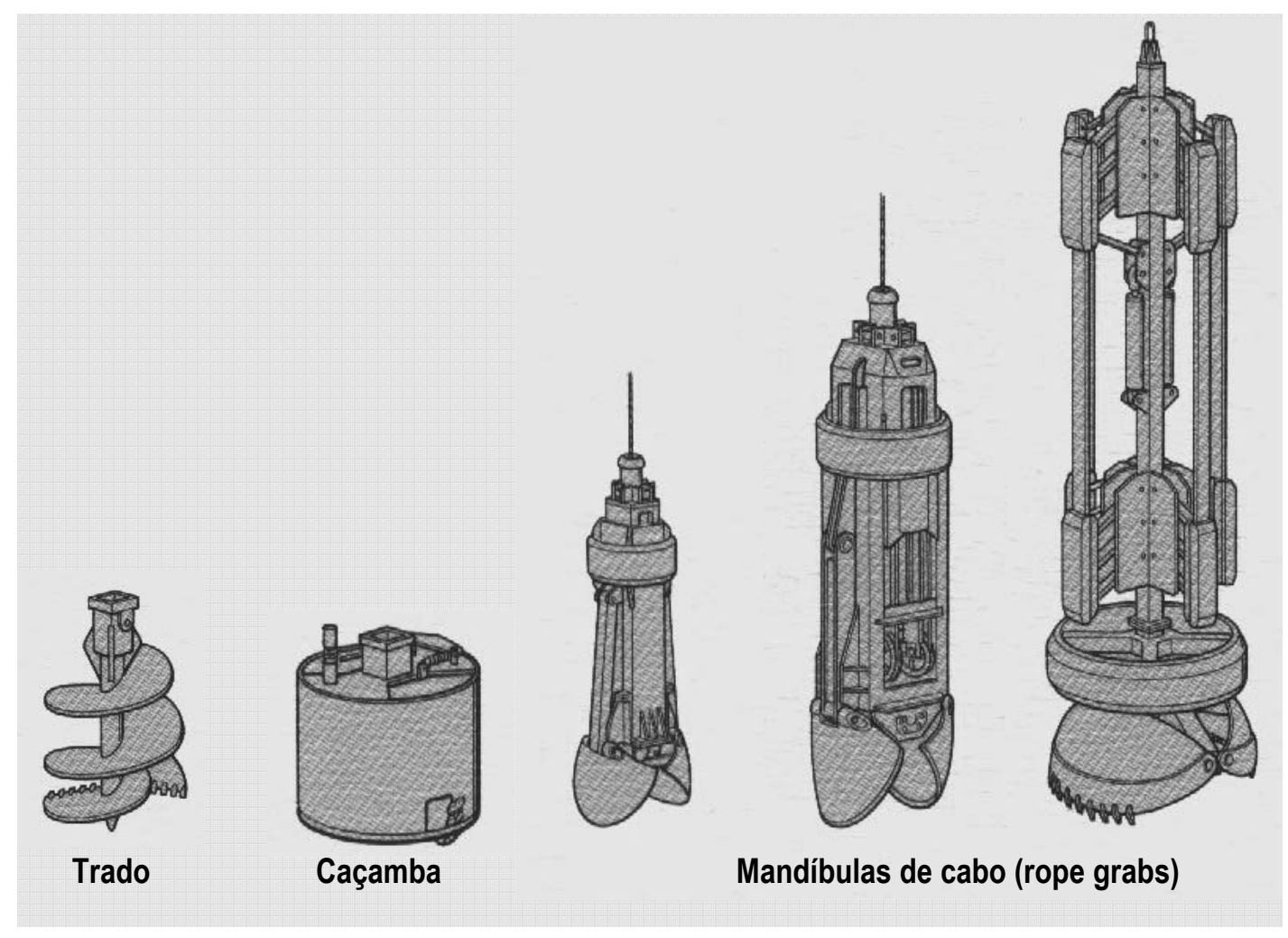

Figura 2.27 - Tipos de ferramentas para estacões (CASAGRANDE, 1999) 


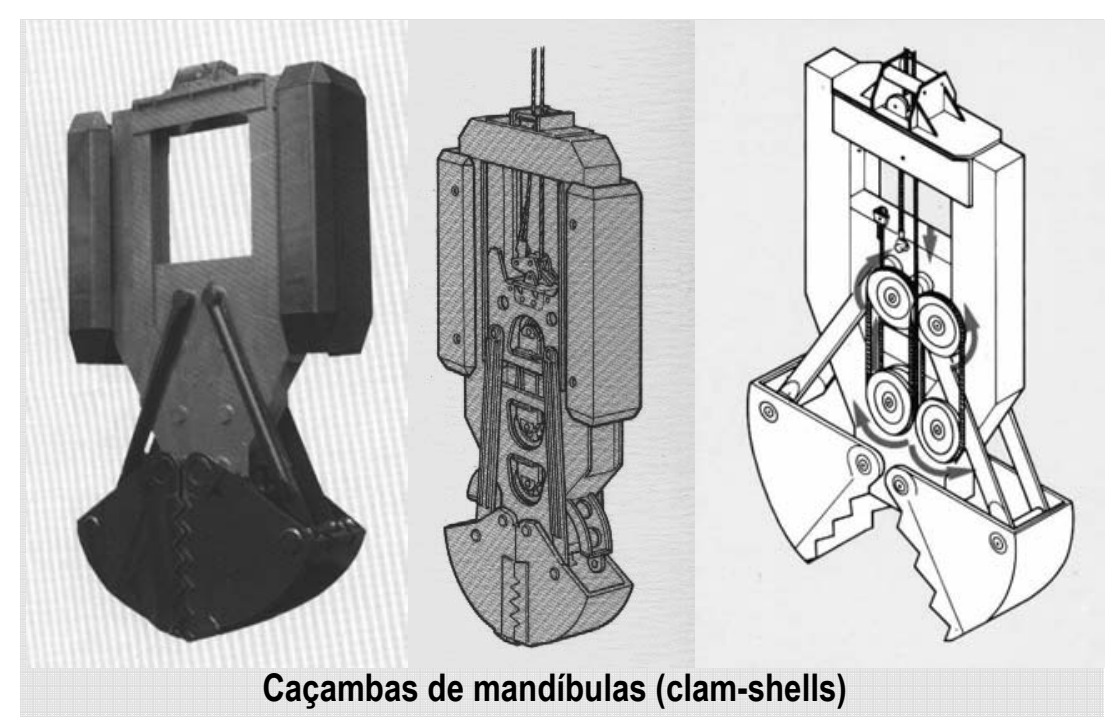

Figura 2.28 - Tipos de ferramentas para estacas Barrete (CASAGRANDE, 1999)

Em solos duros ou rochas os dentes inclinados cortam uma pequena ranhura dentro do solo e o material remanescente é facilmente removido pelo dente raspador chato. Como o dente tem a tendência de subir, estes equipamentos necessitam de um mecanismo para empurrar a caçamba para baixo durante a rotação (pull-down). As ferramentas atuais conseguem perfurar rochas com pressão de até $100 \mathrm{kN} / \mathrm{mm}^{2}$. Podem, ainda, serem utilizados dentes escarificadores com a forma de cinzéis redondos montados em trados (Figura 2.27) ou utilizadas ferramentas de impacto no fundo do furo, para pulverizar o material, permitindo a penetração da ponta. Isto pode ser feito com martelos de queda livre, martelos pneumáticos de fundo e através da aplicação de pressão estática descendente em rollers dotados de bits de carbono-tungstênio.

Quando o furo não é estável por si só, torna-se necessária a utilização de suporte para a escavação, que pode ser rígido, através de tubos de revestimento, ou feito através de lama de estabilização introduzida na perfuração. Os tubos de revestimento são de aço, introduzidos por vibração, por oscilação ou por rotação e retirados concomitantemente com a concretagem. O uso de lama em perfurações para estabilizar e auxiliar na remoção dos detritos é muito antigo, tendo sido usado pelos egípcios em 3.000 AC (SAEZ, 1996). Essa lama pode ser uma 
mistura de água com bentonita ou uma solução de água com polímeros (cadeia longa de moléculas de baixo peso molecular).

Os principais sistemas de remoção dos detritos são o trado, a caçamba, as mandíbulas de cabo (rope grabs) e as mandíbulas de caçamba (clam-shells). Em condições secas, geralmente são utilizados trados porque permitem o fácil enchimento e esvaziamento. Caçambas são usadas em furos cheios de água e a descarga do material escavado é feito na superfície pela liberação das pás do fundo.

Geoforum (2002) afirma que estacas escavadas podem ter essa limpeza feita através de fluxo direto (os materiais escavados são trazidos à superfície por fora da haste de perfuração pelo espaço anelar formado entre a haste da broca e o solo) e de fluxo indireto (a mistura de fluido e detritos sobe por dentro da haste oca da broca até a superfície e o agente de fluxo desce no espaço anelar entre os revestimentos interno e externo). A circulação dos detritos pela mistura fluida é obtida por bomba de sucção, airlift e jato de bombeamento.

A execução destas estacas deve começar com a instalação de um tubo guia (ou mureta guia, no caso da estaca Barrete), para garantir o correto posicionamento do equipamento e iniciada a escavação. Deve ser introduzida lama de estabilização no furo, tão logo se atinja o nível freático ou condições instáveis. O nível interno deve ser mantido cerca de $2 \mathrm{~m}$ acima do nível freático, de modo a garantir uma carga hidráulica positiva na parede da escavação.

A escavação prossegue com a observação e comparação dos materiais escavados com os obtidos pela sondagem, para confirmação da cota de apoio. Esta comparação deve ser feita em termos das características visuais do material e da dificuldade de escavação observada pelo operador. 
Ao final da escavação deve ser feita a limpeza final do furo, com a circulação de lama estabilizante em boas condições, introduzida a armadura, o tubo tremonha com uma bola plástica no funil, e iniciada a concretagem. Esta deve ser feita de forma ininterrupta, com concreto com slump maior que $175 \mathrm{~mm}$ (Figura 2.29). Estando a lama limpa no furo, não só a suspensão é efetivamente arrastada e deslocada para cima, mas também a subida do concreto promove a limpeza da superfície lateral da escavação, proporcionando um bom contato com as paredes da escavação.

A estaca Barrete apresenta a vantagem de ter uma relação superfície lateral/seção transversal maior que o estacão e pode ser combinada de formas diversas, como uma cruz, ou um "H", aumentando ainda mais esta relação e, também, a sua rigidez, para melhorar a resistência à flambagem. No entanto, a ponta da estaca Barrete representa uma parcela da capacidade de carga menor que no caso do estacão e, portanto, assume menor importância no estudo da contribuição da resistência de ponta (Figura 2.30).

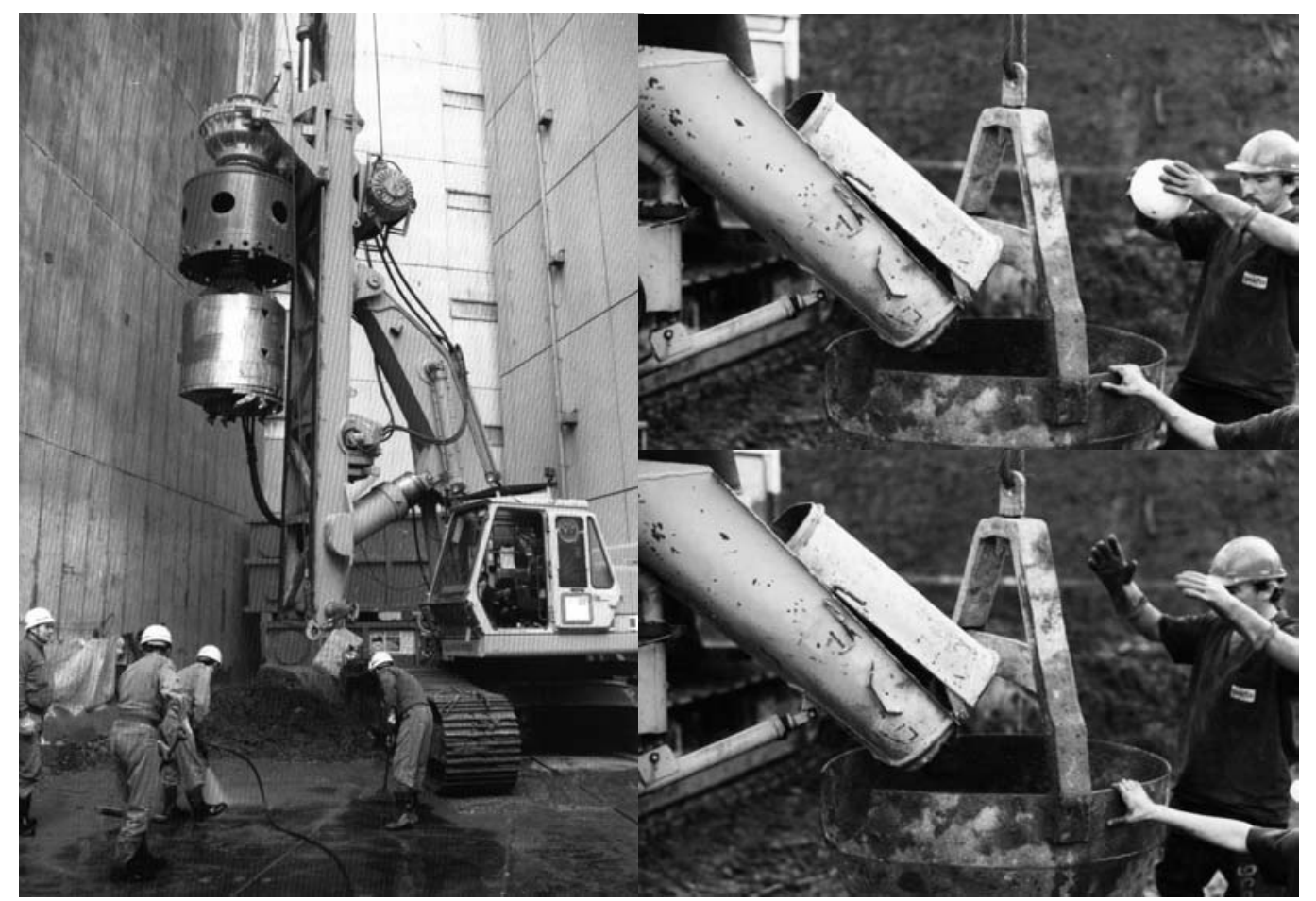

Figura 2.29 - Execução de estacões (BAUER, 1997; particular, 1999) 


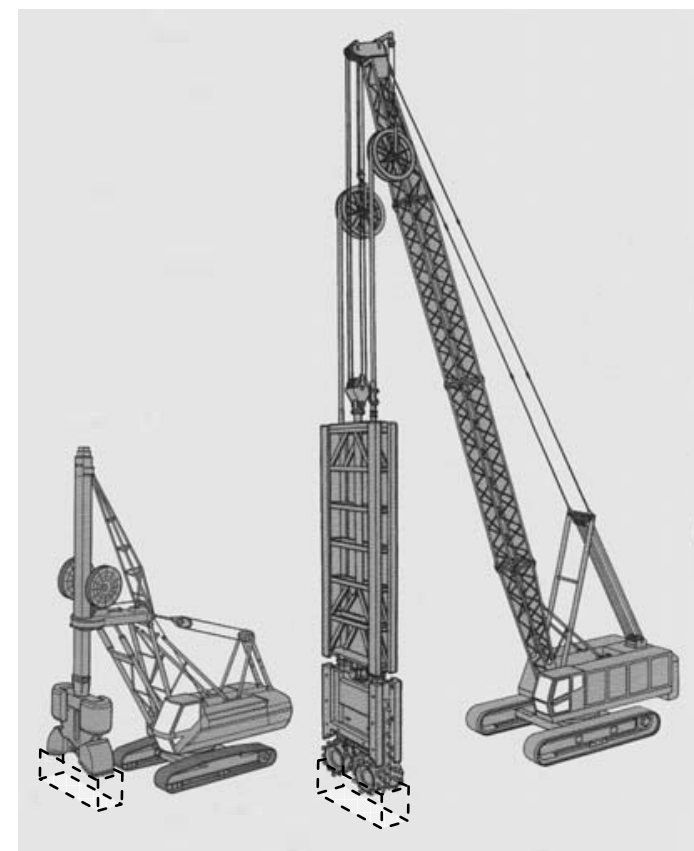

Figura 2.30 - Equipamentos para execução de estacas Barrete (CASAGRANDE, 1999)

A produção diária média é da ordem de 40 metros.

Sliwinski (1979) mostra que os principais efeitos da instalação deste tipo de estaca são:

(a) Redução do confinamento provocado pelo volume de solo removido. No caso das argilas, há alterações do estado de tensões do solo, afetando a estrutura e o teor de umidade;

(b) Formação de gradientes hidráulicos, devidos às oscilações do nível d'água dentro da escavação, durante as manobras verticais da caçamba;

(c) Efeito de êmbolo causado pela subida rápida da ferramenta de corte.

Além disso, a ocorrência de detritos no fundo da escavação provoca a redução da capacidade de carga da ponta, conforme preconiza a NBR-6122 (ABNT, 1996) no subitem c do item 7.1.2: "No caso especifico de estacas escavadas, face aos elevados recalques necessários para a mobilização da carga de ponta (quando comparados com os recalques necessários para a mobilização do atrito lateral) e por existirem dúvidas sobre a limpeza de fundo, a 
resistência de atrito prevista na ruptura não pode ser inferior a $80 \%$ da carga admissível a ser adotada...."

\subsection{6- Estacas Raiz e Micro Estacas}

Essas estacas podem pertencer a dois grupos principais:

(a) Estacas Raiz, caracterizadas por injeção a baixa pressão;

(b) Micro Estacas, caracterizadas por injeção através de tubo com válvulas, com alta pressão.

De qualquer modo, ambas são caracterizadas pelo pequeno diâmetro, pela execução de perfuração através de revestimento em todo o comprimento e pela aplicação de pressão na argamassa de preenchimento.

A característica mais importante é sua capacidade de atingir elevadas profundidades e atravessar materiais muito resistentes, como rochas, e fazendo com que o elo mais fraco não seja a transferência de carga para o solo, mas sim a resistência estrutural da estaca (CEPOLINA, 2000). Comparativamente com outros tipos de estacas, apresentam tensão média de trabalho superior às outras, com fator de segurança estrutural menor. A Tabela 2.7 mostra esta comparação.

Tabela 2.7 - Tensão média e fator de segurança de várias estacas (CEPOLINA, 2000)

\begin{tabular}{ccc}
\hline Estaca & Tensão média (MPa) & "Fator de segurança” estrutural \\
\hline Escavadas com lama & $\sim 5$ & $\sim 4$ \\
\hline Hélice contínua & $\sim 5$ & $\sim 4$ \\
\hline Pré-moldadas & 9 a 11 & $\sim 3,5$ a 4 \\
\hline Franki & $\sim 6$ & $\sim 3$ a 5 \\
\hline Raiz & 15 a 20 & $\sim 2$ \\
\hline
\end{tabular}

Equipamento típico utilizado para estas estacas pode ser visto na Figura 2.31. 


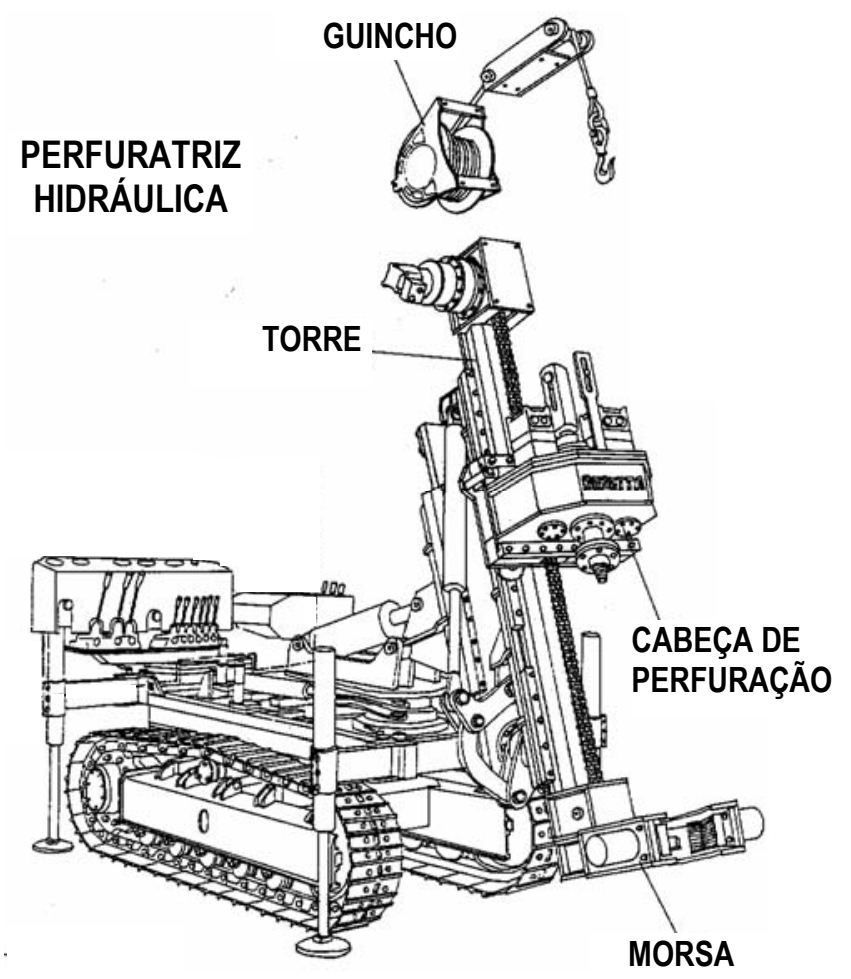

Figura 2.31 - Exemplo de equipamento para a execução de estacas raiz e micro estacas (BERETTA, 1999)

A perfuração se desenvolve por rotação ou rotopercussão com o revestimento contínuo do fuste (Figura 2.32). A remoção dos detritos é feita através da circulação da água que é introduzida pelo tubo de revestimento e que reflui pelo espaço anelar entre o tubo e o maciço. À medida que prossegue a perfuração, novos segmentos de tubo são acoplados por juntas rosqueadas, de forma a manter a condição de fluxo anelar da água com os detritos.

Ao fim da perfuração uma armadura especial é posicionada dentro do tubo de perfuração e um tubo de concretagem é colocado no fundo do tubo de perfuração. Através deste tubo é lançada uma argamassa de cimento e areia, com 500 a $600 \mathrm{~kg}$ de cimento por metro cúbico de areia e com fator água/cimento igual a 0,6 . O lançamento da argamassa de baixo para cima promove a expulsão da água e a remoção final de possíveis detritos. Após a argamassa preencher todo o tubo, é instalado um tampão na sua extremidade superior e aplicada pressão enquanto tubo é retirado. 
No caso de micro estacas, a diferença é que a injeção é feita através de tubo com válvulas ao longo do fuste, e com alta pressão.

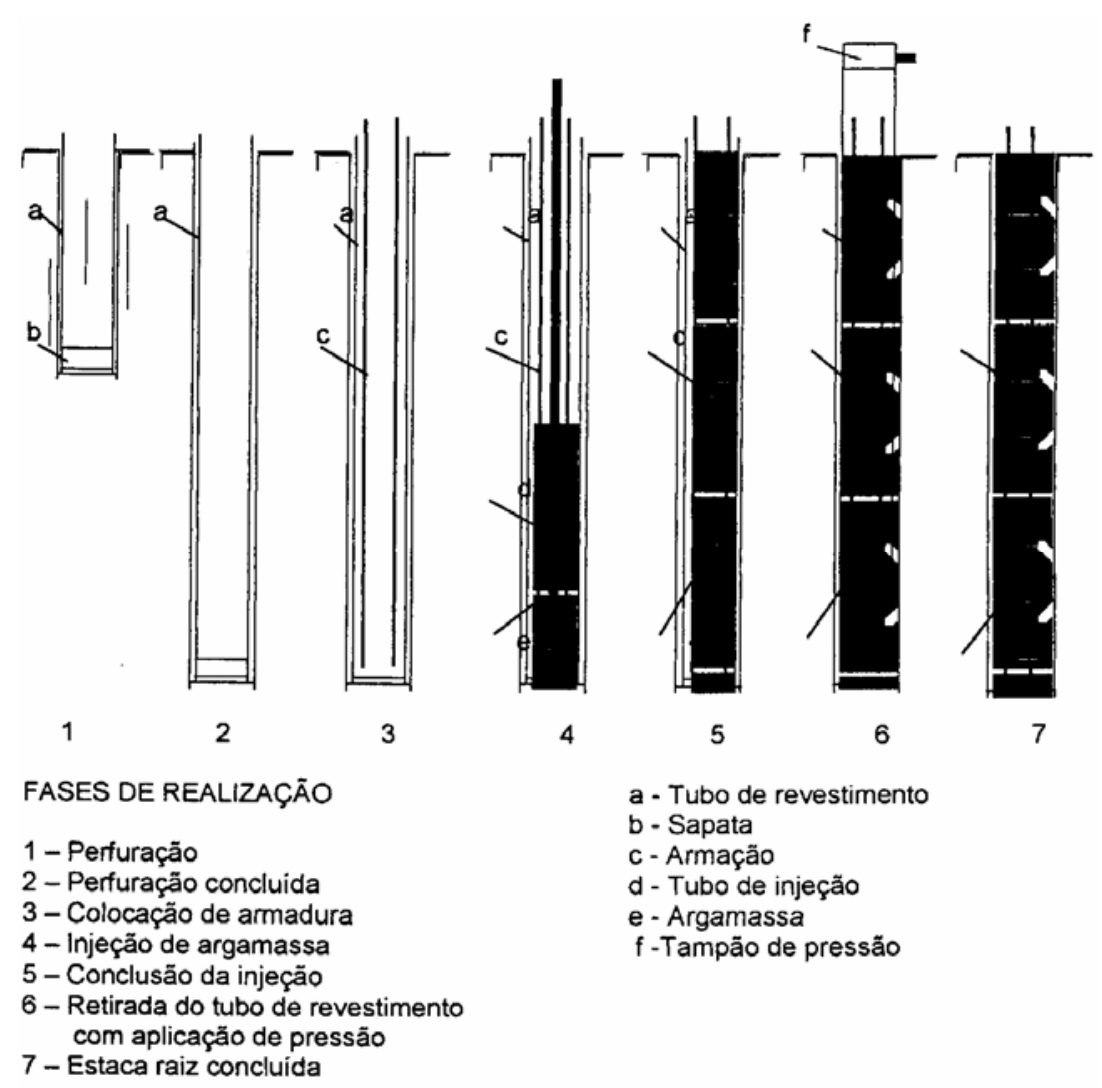

Figura 2.32 - Execução de estacas raiz (TAROZZO; GRANDIS, 2000)

Com relação à operação de perfuração, Sodré (1994) afirma "No entanto, diferente do que se poderia imaginar, a operação de perfuração de estacas raiz, na qual o uso de circulação de água é comumente empregado, não causa distúrbios significativos no solo. Isto se deve, segundo Koreck (1978) e Corrêa (1988), a rapidez das diversas fases de execução (curto tempo entre a perfuração e o preenchimento do furo com a argamassa), o diâmetro reduzido e a utilização de camisa metálica, que praticamente, não permitem relaxação do solo ao redor do furo, inibindo os processos anteriormente descritos.

Assim sendo, os efeitos causados pelo amolecimento do solo, apesar de inevitáveis, são minimizados pela técnica de perfuração e pelo tempo de construção da estaca que contribuem para o bom desempenho quanto à capacidade de carga destas estacas em solos coesivos. 
Para solos não coesivos a operação de perfuração aparentemente não causa distúrbios significativos que possam reduzir a capacidade de carga (KORECK, 1978 e WELTMAN, 1981).

Com relação à operação de injeção, Salioni (1985), apud Sodré (1994) afirma que pode provocar três tipos de ocorrências (Figura 2.33):

(a) Injeção de preenchimento de vazios: não ocorrem alterações de volume e estrutura do solo;

(b) Injeção com deslocamento dos grãos: os vazios são preenchidos pela argamassa;

(c) Injeção por fissuração (clacagem): ocorre a ruptura hidráulica do solo, com o aparecimento de fissuras.

(a)

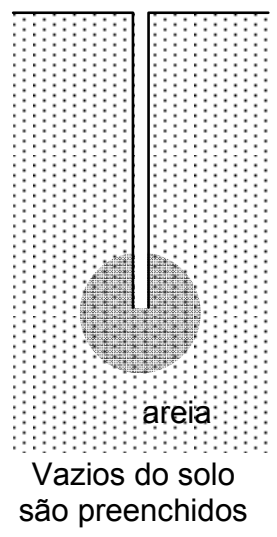

(b)

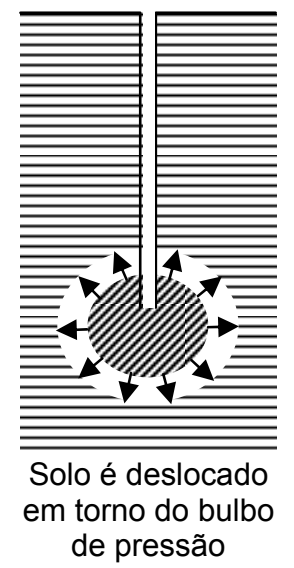

(c)

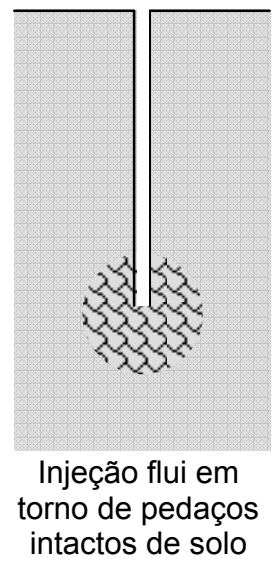

Figura 2.33 - Efeitos da injeção nos solos (SALIONI, apud SODRÉ, 1996)

$\mathrm{Na}$ situação (a) os vazios são suficientemente grandes para permitir o fluxo da calda de injeção, resultando em seu preenchimento. Na situação (b) os vazios são menores, a calda não consegue fluir através deles, comprime o terreno e forma um bulbo de forma aproximadamente esférica. Em terrenos granulares isto é equivalente, segundo Meyerhof 
(1959), a um acréscimo do ângulo de atrito interno do solo. Na situação (c), ao tentar aumentar o bulbo anterior, chega-se a uma pressão limite que provoca a ruptura hidráulica do solo (clacagem) e a injeção encontra um caminho de menor resistência, por onde se propaga, sem acréscimo da capacidade de carga (COSTA NUNES, 1992).

A instalação das estacas raiz deve, pois, buscar o nível de injeção que possa tirar maior proveito do maciço, preenchendo os vazios e comprimindo o solo sem, contudo, provocar a clacagem da calda de injeção.

A produção média diária é da ordem de 50 metros.

\subsection{7- Estacas Hélice Contínua (CFA - Continuous Flight Auger)}

A perfuratriz é dotada de um trado helicoidal contínuo, com haste interna vazada, por onde é feita a concretagem (Figura 2.34).

A perfuração avança com o movimento rotativo do trado e com o controle da sua descida de modo a evitar relação rotação/avanço elevada a ponto de transportar muito rapidamente o material para cima, reduzindo o confinamento do furo ou muito baixa a ponto de penetrar no solo sem desagregá-lo, dificultando a sua remoção. A relação ideal é aquela em que o volume solo transportado para cima é igual ao volume de trado que penetra o solo. Desta forma, o solo sofreria pouca perturbação, sem alteração significativa no seu confinamento.

O solo transportado à superfície deve ser comparado com o obtido pela sondagem assim como deve haver o acompanhamento de toda a instalação da estaca (perfuração e concretagem) através das leituras dos sensores ligados ao computador da cabine. Este acompanhamento permite verificar a proximidade da cota de apoio de projeto. 


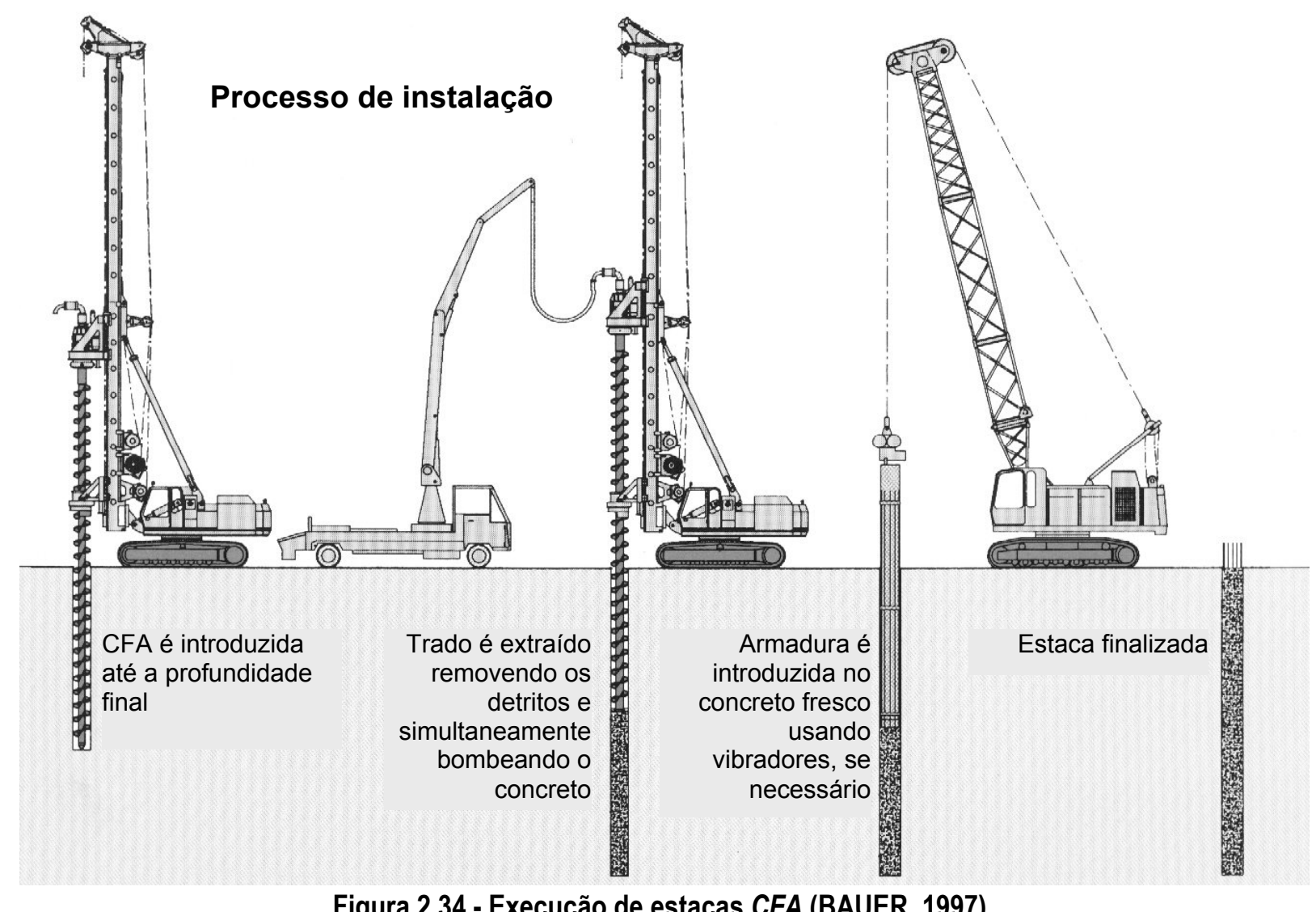

Figura 2.34 - Execução de estacas CFA (BAUER, 1997)

Ao final da perfuração, o trado é levantado ligeiramente, para permitir a expulsão do plug na sua extremidade. O concreto é, então, bombeado através da tubulação ligada ao topo do trado, expulsando o plug e preenchendo o espaço na ponta da estaca. As especificações dos materiais empregados estão na Tabela 2.8 (ABEF, 1999). A seguir, prossegue o bombeamento do concreto, com a elevação contínua, sincronizada e sem giro do trado, de modo a garantir que o concreto seja bombeado com pressão suficiente para preencher toda a escavação, sem romper o solo ou subir entre o trado e a superfície da escavação. À medida que o trado é erguido, uma ferramenta de limpeza gira entre as pás do trado, removendo o solo.

A concretagem termina com a retirada do trado, e com o concreto subindo até 50 centímetros acima da cota de arrasamento. A armadura é, então, imediatamente introduzida e posicionada na sua cota definitiva. Caso a armadura tenha sido projetada para resistir a esforços de tração ou de carregamento horizontal e seja relativamente pesada, pode ser introduzida com o auxílio 
de pequenos golpes de um peso ou com o auxílio de um vibrador. Para isto, deve dispor de ponta cônica e pequenas peças em forma de esquis presas à gaiola, para direcionar a penetração.

Tabela 2.8 - Especificações dos materiais das estacas CFA (ABEF, 1999)

\begin{tabular}{ccc}
\hline Materiais & Especificações & $\begin{array}{c}\text { Normas } \\
\text { brasileiras }\end{array}$ \\
\hline Aço & CA 50 e CA 25 conforme diâmetros & NBR-7480 \\
constantes do projeto & NBR-6152 \\
\hline Agregado & Pedrisco/Areia & NBR-7211 \\
\hline Cimento & CP III, sem adição de escória & \\
\hline $\mathrm{f}_{\mathrm{ck}}=20 \mathrm{MPa}$ & slump $=(22 \pm 2) \mathrm{cm}$ \\
slump flow 48 a $53 \mathrm{~cm}$ & NBR-8953 \\
Concreto & fator água/cimento $=0,53 \sim 0,56$ & NBR-5738 \\
& consumo mínimo de cimento $=400 \mathrm{~kg} / \mathrm{m}^{3}$ & NBR-5739 \\
& exsudação $\leq 1,0 \%$ & NM-67 \\
& teor de ar incorporado $\leq 1,5 \%$ & \\
Início da pega $\geq 3,0$ horas &
\end{tabular}

Segundo Van Weele (1988), durante a perfuração podem ocorrer subpressões próximo do fundo, fazendo o solo se mover para o trado, que o transporta para cima. Em solos permeáveis saturados, as subpressões provocam poro pressões e, com o fluxo, partículas de solo são movidas para dentro do trado. Este solo, quando está com muita água, pode subir ao longo da hélice. O resultado é que o nível de tensões no solo ao redor do furo decresce substancialmente e pode resultar em perda de material nos arredores do furo.

Em solos coesivos, o decréscimo de pressão afeta fortemente a qualidade do solo dos arredores do furo. Van Weele (1988) sugere a injeção de ar comprimido próximo ao pé do trado para prevenir a ocorrência de supressões e facilitar o movimento de subida do solo escavado. 
As principais vantagens são a ausência de vibração, a garantia da geometria mínima imposta pelo trado, a monitoração da instalação, a possibilidade de avançar abaixo do nível freático sem revestimento e alta produção diária, da ordem de 100 metros.

\subsection{8- Estacas Ômega}

Dentre as estacas do tipo screw pile, as principais são a Atlas (simples e com revestimento permanente), a De Waal, a Spire e a Ômega. Cada um destes tipos teve o projeto de cabeça de perfuração desenvolvido com o objetivo de melhorar a versatilidade, a produtividade e a capacidade de carga (Van IMPE, 1997). Destes, o projeto da ferramenta de perfuração da estaca Ômega parece ser o que, atualmente, melhor atende a este objetivo e Bustamente e Gianeselli (1998) o classifica como "uma tentativa convincente para racionalizar estas observações". O equipamento é dotado de uma cabeça especial (Figura 2.35) que perfura o terreno, sem a retirada de solo, compactando-o contra as paredes do furo. Para isso, a perfuratriz necessita dispor de alto torque para permitir atravessar os estratos e deslocar lateralmente o solo.

A forma de parafuso cônico da cabeça de perfuração permite iniciar o furo e, com a mudança do seu passo, impede a subida do solo, deslocando-o horizontalmente e o compactando contra a parede do trecho perfurado. A ponta desta ferramenta também dispõe de uma tampa para impedir a entrada de solo e água durante a escavação e permitir a colocação da armadura e a concretagem.

Ao final da perfuração, a armadura é introduzida por dentro da haste de perfuração e o concreto é bombeado por dentro desta haste, concomitantemente com a sua subida, com rotação no mesmo sentido da perfuração. Caso a armadura não tenha sido introduzida anteriormente, pode ser introduzida ao final da concretagem, como no caso das estacas $C F A$. 


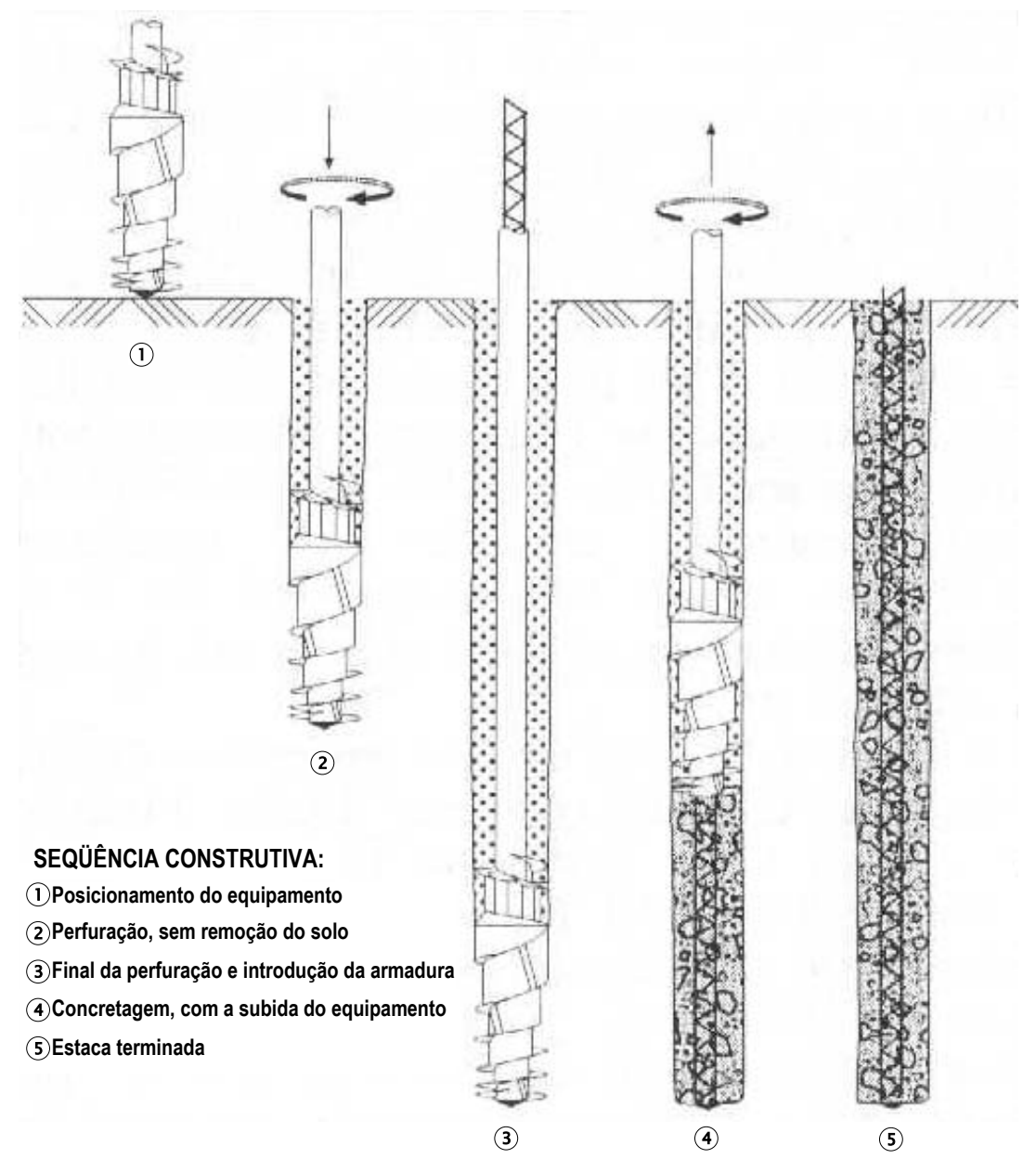

Figura 2.35 - Execução de estacas Ômega (BOTTIAU et al., 1998)

As cargas de trabalho normalmente utilizadas, dependentes do perfil do terreno e das características da obra (FUNDESP, 2000), são mostradas na Tabela 2.9 a seguir:

Tabela 2.9 - Cargas de trabalho normalmente utilizadas (FUNDESP, 2000)

\begin{tabular}{ccc}
\hline Diâmetro $(\mathrm{cm})$ & Carga mínima $(k N)$ & Carga máxima $(k N)$ \\
\hline 31 & 400 & 500 \\
\hline 36 & 550 & 650 \\
\hline 42 & 700 & 800 \\
\hline 46 & 800 & 1000 \\
\hline 51 & 1100 & 1300 \\
\hline 60 & 1400 & 1700 \\
\hline
\end{tabular}

As principais vantagens são as mesmas das estacas $C F A$, acrescida do aumento do confinamento do solo, devendo comportar-se de forma similar às estacas de deslocamento 
(BUSTAMANTE; GIANESELLI, 1998 e ALBUQUERQUE, 2001). Requer equipamentos com maior torque disponível e sua produção diária média é da ordem de $100 \mathrm{~m}$.

\subsection{9- Estaca Ômega $B^{+}$}

Buscando melhorar o processo de instalação das estacas Ômega simples, surgiu uma variante, denominada Ômega $B^{+}$(BOTTIAU et al., 1998). Foi desenvolvida através da alteração do processo tradicional para melhorar a contribuição da resistência de ponta.

Sua instalação é idêntica à daquela, com exceção das etapas destinadas à formação de uma base alargada (Figura 2.36).

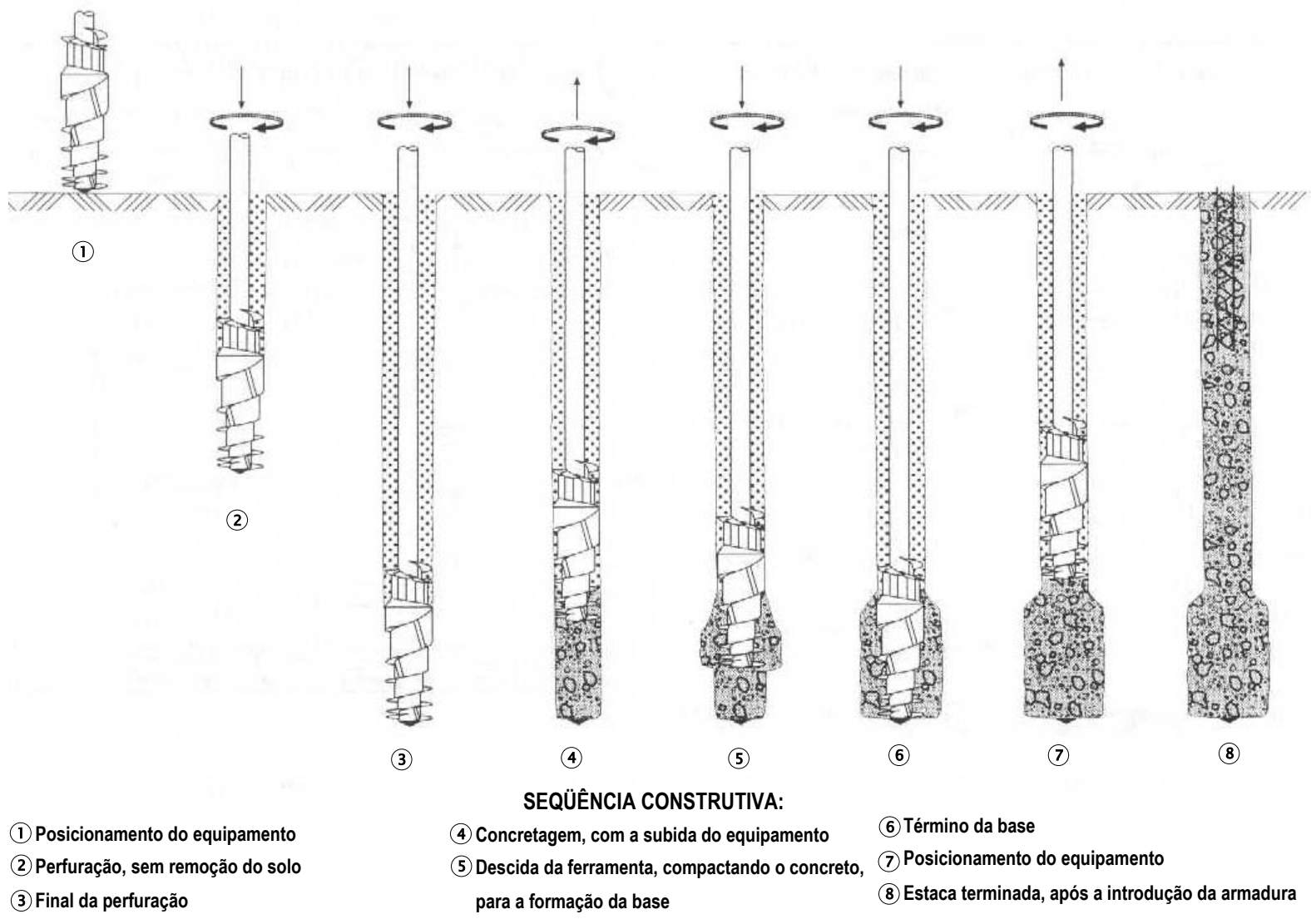

Figura 2.36 - Execução de estaca Ômega+ (BOTTIAU et al., 1998)

Isto é obtido através do início do bombeamento de concreto seco e pressão entre 5 e 10 bar enquanto a cabeça de perfuração é erguida cerca de um metro. A seguir, a cabeça de 
perfuração é novamente inserida, algumas vezes no concreto seco e fresco, empurrando-o contra a parede do furo e promovendo o alargamento da base. Após a formação da base, a concretagem é retomada e finalizada, com a introdução da armadura.

As principais vantagens são as mesmas da estaca Ômega simples, associadas à da formação da base alargada, com conseqüente aumento da capacidade de carga da estaca (Van IMPE et al., 1998). As desvantagens desta técnica são devidas ao uso de concreto seco, a redução da produtividade em relação às estacas Ômega simples e às limitações impostas pela potência do equipamento.

\subsubsection{0- Estacas com alargamento da base}

O alargamento da base aqui tratado será aquele obtido por escavação mecanizada através de ferramenta apropriada, com o objetivo de aumentar a capacidade de carga de estacas apoiadas em solo resistente. Segundo Tomlinson (1997) e Geoforum (2002), só deve ser utilizada em solos estáveis e pode ser de dois tipos básicos (Figura 2.37).
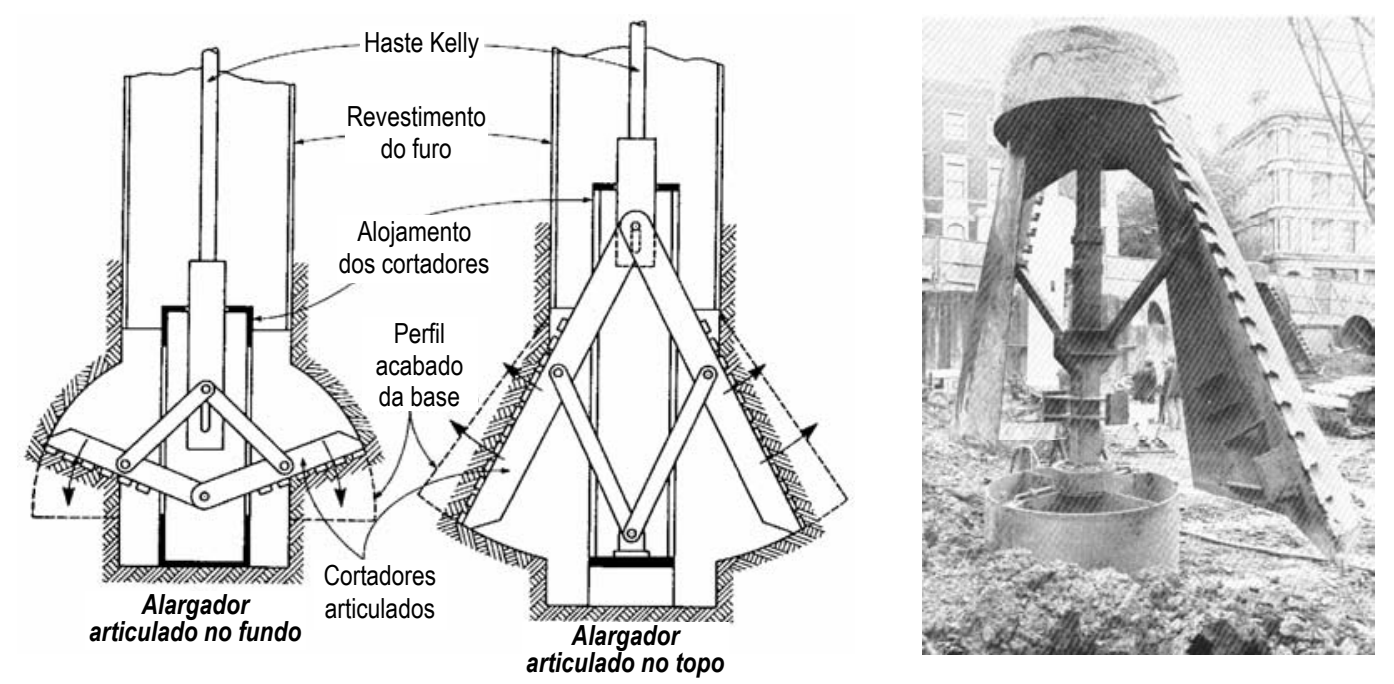

Figura 2.37 - Ferramentas utilizadas para o alargamento da base (TOMLINSON, 1997)

A ferramenta alargadora desce, pelo furo, fechada e pode ser expandida na base, de acordo com a necessidade. Comumente, o ângulo de corte está compreendido entre 45 e 60 graus e o diâmetro máximo é cerca de três vezes o diâmetro do fuste. Os detritos são removidos através 
da ferramenta mecânica, mas pode ser feita de forma manual, porém com algum risco. A escavação é demorada, pois o processo de descer a ferramenta, abri-la, escavar, fechá-la e retirá-la do furo para a descarga, tem que ser repetido algumas vezes por causa da sua limitação volumétrica. Normalmente, esta técnica é usada com diâmetros de fuste a partir de setenta centímetros.

A principal vantagem é poder aproveitar estratos resistentes, com a utilização de uma parcela maior de resistência de ponta, obtendo maior capacidade de carga e economia de concreto. As desvantagens são a redução da produtividade, a dificuldade e o risco da limpeza do fundo.

\subsubsection{1- Estacas com grauteamento}

Existem diversos processos de grauteamento disponíveis para estacas (GEOFORUM, 2002), tanto na superfície lateral de estacas, como na ponta. Costa Nunes (1992), relata um caso de obra onde foi utilizada injeção de calda de cimento sob a base de alguns tubulões, com o objetivo de melhorar o terreno. A Figura 2.38 mostra o perfil do terreno e os resultados das provas de carga executadas antes e depois da injeção da calda sob a base de um desses tubulões. 

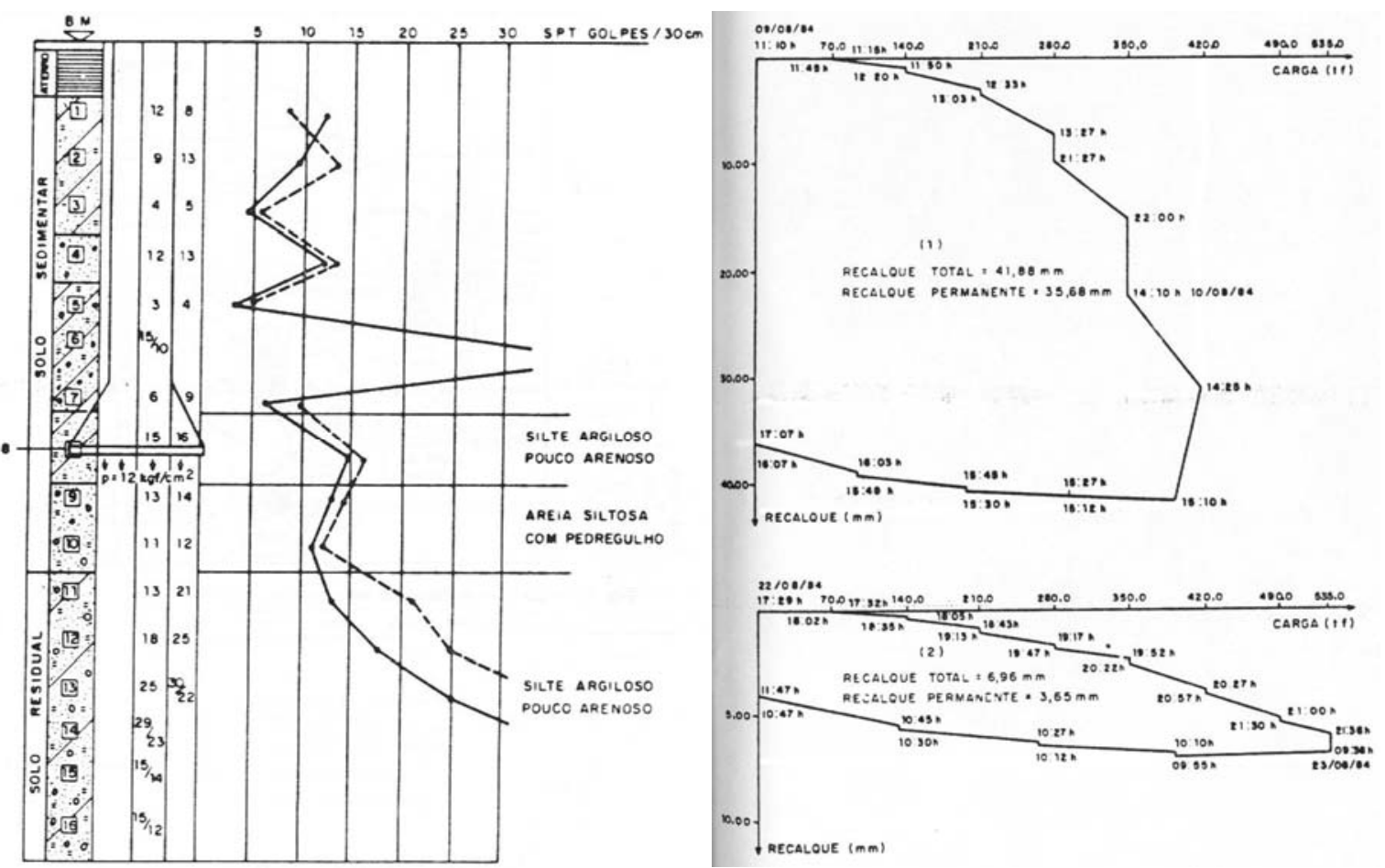

Figura 2.38 - Perfil do terreno e resultado de prova de carga em um tubulão antes e depois do grauteamento (COSTA NUNES, 1992)

A empresa alemã Bauer utiliza seu próprio sistema de grauteamento. Na Figura 2.39, estão ilustrados um esquema do sistema, a foto de uma estaca exumada e os resultados de duas provas de carga executadas numa estaca normal e em outra com grauteamento, onde pode ser vista a mudança na capacidade de carga e no comportamento.
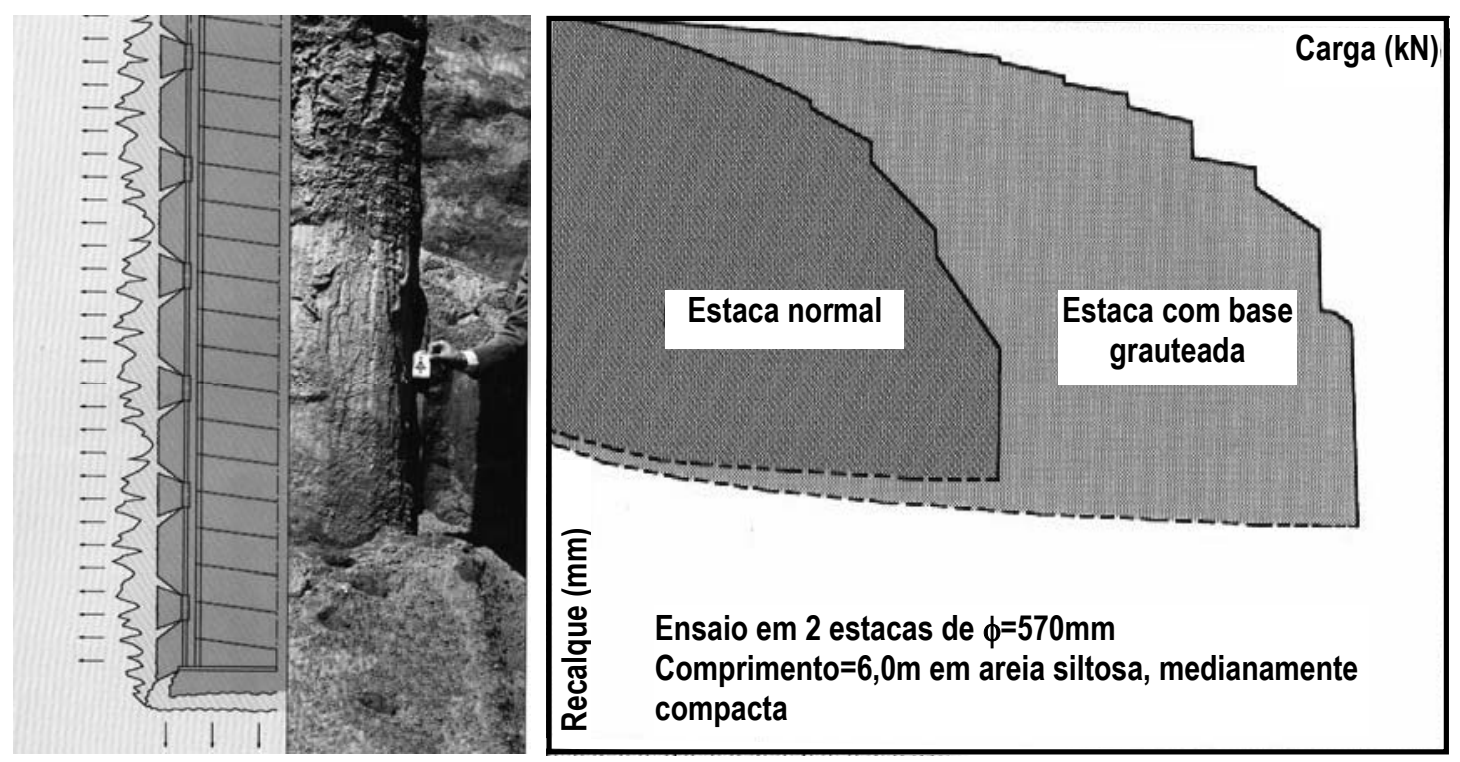

Figura 2.39 - Sistema Bauer de grauteamento (BAUER, 1997) 
Este sistema, que promove o grauteamento do fuste e da base, é composto de tubos dotados de válvulas localizados próximos à superfície da estaca. Após a execução da estaca, é feita a injeção de calda de cimento, que se distribui em todo o fuste e na base da estaca.

O grauteamento pode melhorar significativamente as parcelas de atrito lateral e de resistência de ponta e tirar proveito das características dos diversos perfis. No entanto, requer preparo inicial das estacas, equipamento especial e dependem de algum tempo entre as fases de execução. Além disso, o consumo de cimento geralmente é elevado, tornando o processo dispendioso.

\subsubsection{2- Estacas com tratamento do solo com resinas químicas}

À semelhança do grauteamento com calda de cimento, podem ser feitas injeções no terreno objetivando o aumento da capacidade de carga de estacas, com a utilização de resinas químicas. Algumas resinas, como o poliuretano hidroativado, têm características adequadas para este fim, principalmente por poderem dispor de viscosidade baixíssima, de cerca de $30 \mathrm{cps}$, menor que a das caldas de cimento. A Figura 2.40 mostra um exemplo de aplicação em uma estaca pré-moldada.
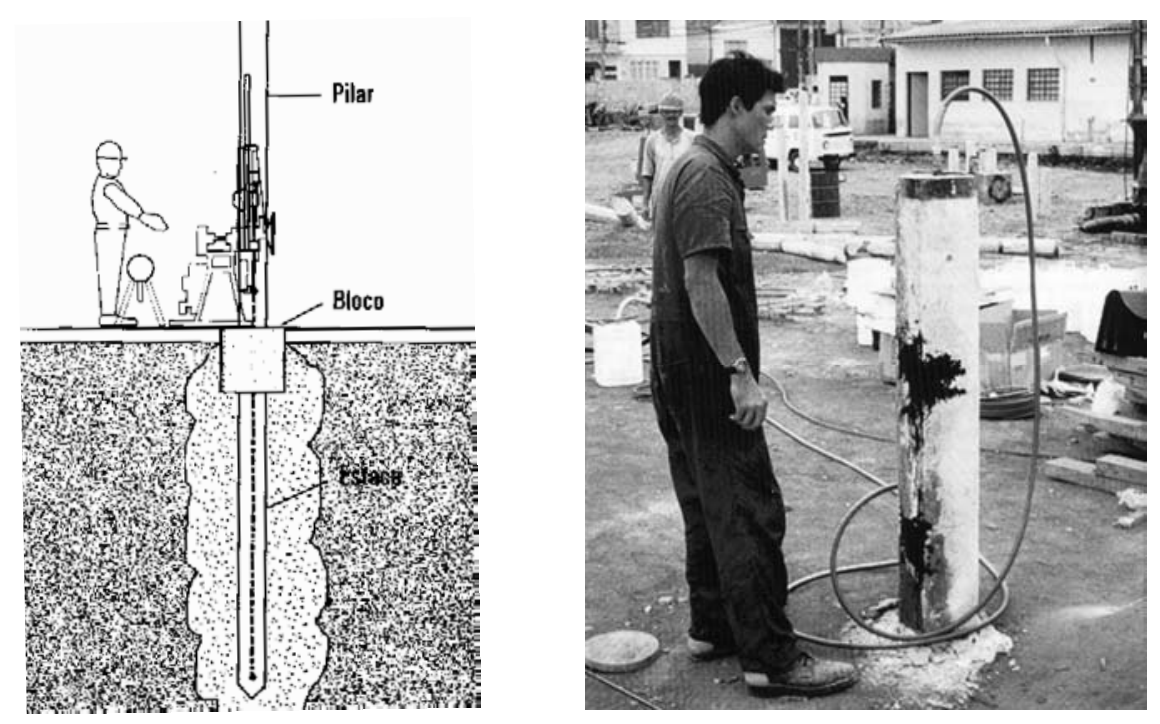

Figura 2.40 - Execução de injeção de resina química (RODRIGUES, 1998) 
As principais vantagens dessas resinas são sua baixa viscosidade e poder aglomerante, superior ao cimento portland. No entanto, além do custo elevado, é ativado com o contato com a água do solo.

\subsubsection{3- Estacas com apiloamento da ponta}

O apiloamento mecânico da ponta da estaca pode ser feito com o uso de tripé e peso de queda livre acionado manualmente ou pelo próprio equipamento de perfuração (Figura 2.41). Neste caso, o equipamento dispõe de um cilindro e um motor extras para movimentar o peso.a operação é muito facilitada porque o equipamento só tem que recuar alguns centímetros para centralizar o peso. O peso apresenta uma ponta chata e é deixado cair em queda livre de alturas de até 8 metros. São aplicados cerca de seis golpes consecutivos no fundo da escavação e o critério de interrupção é meramente através do som percebido pelo operador.

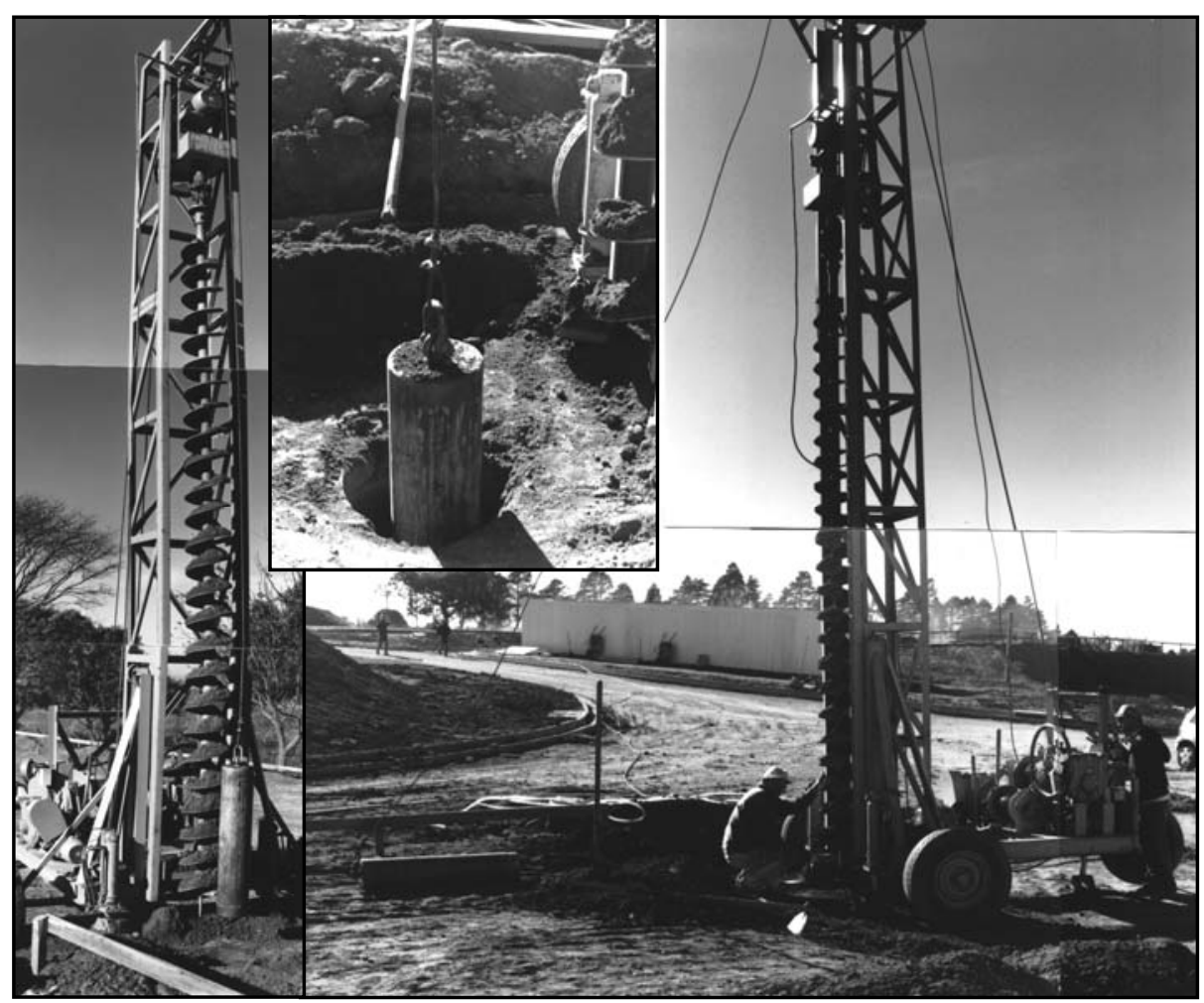

Figura 2.41 - Execução de apiloamento da ponta 
As principais vantagens são a simplicidade, rapidez e o baixo custo. As desvantagens são a falta de controle e de resultados de pesquisas que possam dar suporte técnico adequado.

\subsubsection{4- Estaca com expulsão de plug (VB-pile)}

Massarsch et al. (1988) relatam que, na busca de aliar as vantagens das estacas escavadas com as da estaca Franki, foi desenvolvida uma nova estaca com revestimento recuperável e plug perdido, denominada $V B$-pile.

Nesta estaca, é obtida uma base aumentada e compactada pela expulsão de um plug, usando um martelo de fundo de furo. A seqüência construtiva está mostrada na Figura 2.42. A expulsão do plug se dá após a perfuração e a descida da armadura. É lançado concreto seco ou pedregulho no fundo do furo e um martelo pesado é usado para expelir o plug. As altas forças desenvolvidas pelo impacto deslocam o solo abaixo da base da estaca. A capacidade de carga da estaca é obtida através do monitoramento do volume e da energia necessária para criar a base da estaca.

As principais vantagens são a ausência de vibração durante a etapa de perfuração, só ocorrendo na formação da base e a obtenção desta base representando uma significativa parcela da capacidade de carga da estaca. As desvantagens são os elevados esforços de torque e de levantamento necessários para a perfuração e para a retirada do revestimento. 


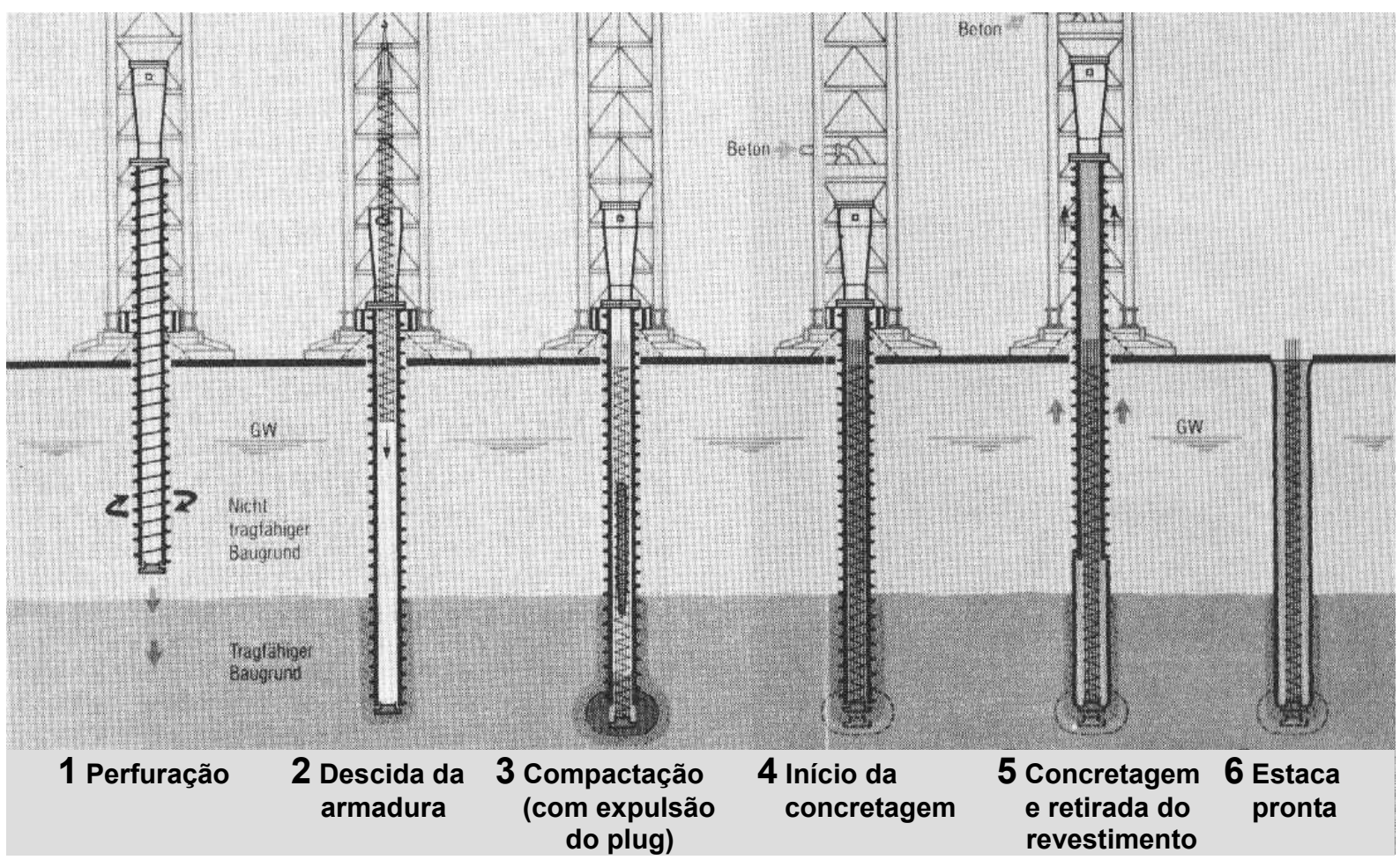

Figura 2.42 - Execução de sistema de expulsão de plug (MASSARSCH et al., 1988)

\subsubsection{5- Método SENTAN}

Este método surgiu como uma tentativa de diminuir a perturbação proveniente da escavação de estacas ou recuperar as características naturais do solo através de um dispositivo de compactação introduzido no fundo da escavação (KONDOU, 1998).

O método foi denominado de método SENTAN, é adequado para os tipos usuais de estacas escavadas. Está baseado na colocação de anéis de concreto ao final da escavação e na projeção destes anéis através de um equipamento especial. A seqüência executiva está na Figura 2.43 . 


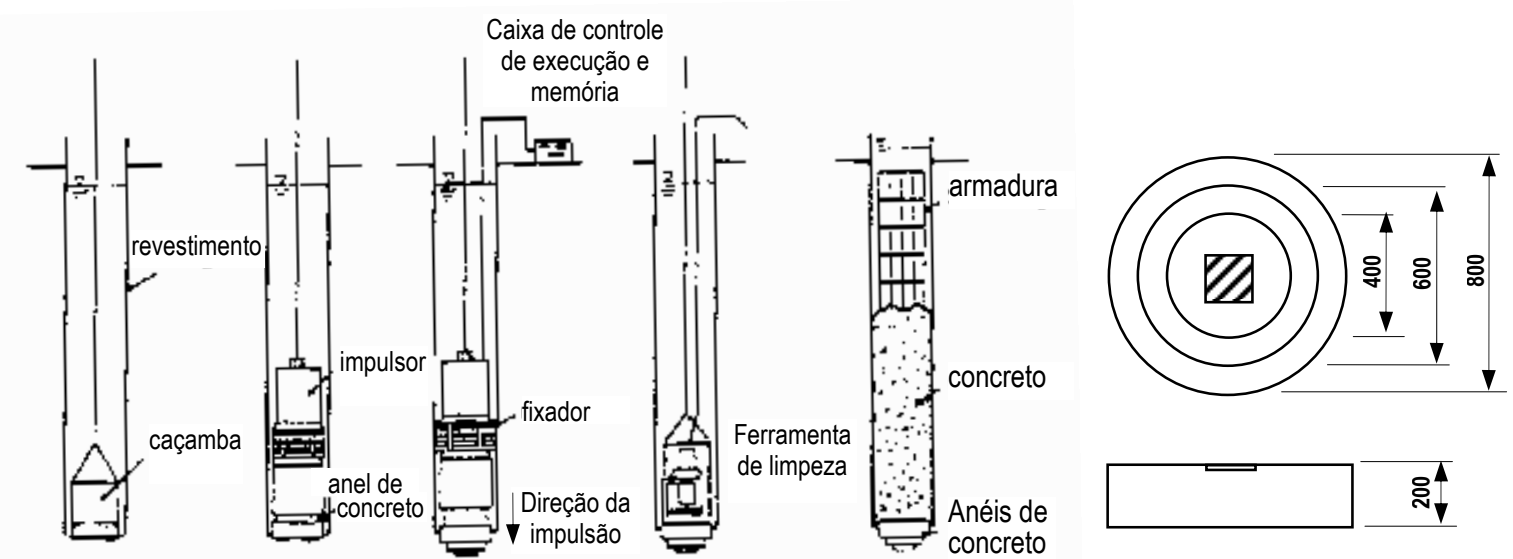

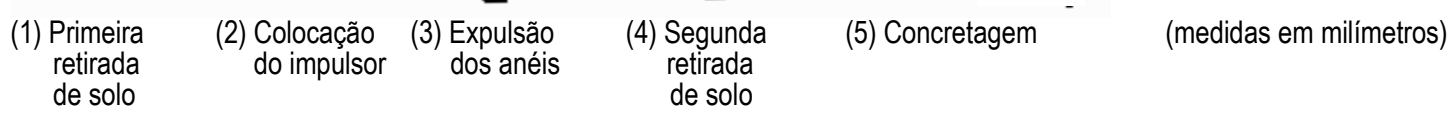

Figura 2.43 - Método SENTAN de compactação da base (KONDOU et al., 1998)

Foram feitas provas de carga em estacas convencionais e executadas com este método e os resultados mostraram aumento da capacidade de carga e da rigidez do sistema.

Permite repetição do carregamento e a diminuição da deformação residual sob carga de trabalho, mas requer operações de colocação, carregamento e retirada do equipamento, com redução da produtividade.

\subsubsection{6- Estaca Soilex}

A estaca Soilex promove o aumento da base através da instalação de um expansor metálico no terreno e da sua utilização para injetar a calda. Segundo (BROMS, 1985; SELLGREN et al., 1985), esse expansor consiste em um tubo fino de aço dobrado, que pode ser instalado por meio de perfuração, cravação, vibração, macaqueamento, ou colocação em um pré-furo. Depois de instalado, o expansor metálico pode ser inflado por injeção de concreto ou graute. Deste modo, forma-se um corpo sólido de aço, preenchido com concreto, com forma e volume pré-determinados em qualquer profundidade no terreno (Figura 2.44). Durante a fase de expansão é criada uma zona de solo densificado, resultante da alta pressão de expansão, que se estende a uma distância de cerca de dois diâmetros de expansor metálico. 

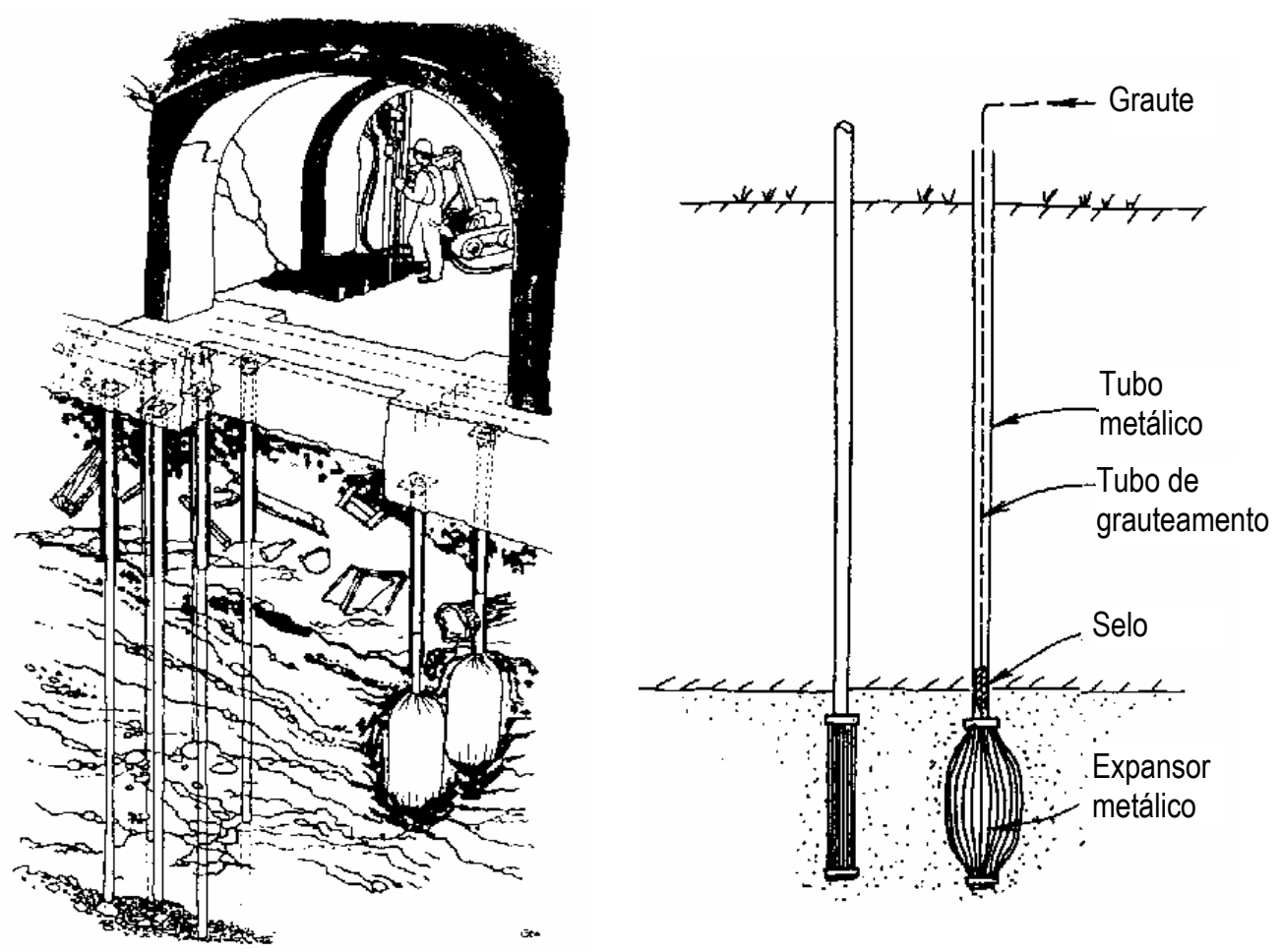

Figura 2.44 - Estacas Soilex (SELLGREN et al., 1985; BROMS, 1985)

O processo de expansão aumenta a densidade de solos granulares soltos e medianamente compactos. Em solos coesivos, a recompressão resulta em um efeito de pré-consolidação e melhora a resistência e a rigidez do solo. O expansor pode ser usado para melhorar a capacidade de carga de estacas cravadas e escavadas.

\subsubsection{7- Célula de pré-carga (BOLOGNESI; MORETTO, 1973)}

Bolognesi e Moretto (1973) utilizaram uma célula de pré-carga no fundo da escavação de estacas escavadas de grande diâmetro utilizadas em uma ponte sobre o rio Paraná.

Os objetivos da implantação desta célula é a possibilidade da aplicação de pressão na base da estaca, aproveitando a reação proporcionada pelo fuste. Com a aplicação da pressão no fundo da escavação, dois efeitos benéficos são atingidos: 1) melhoria da resistência do solo e do contato com a estaca; 2) pré-compressão do solo, com sensível redução dos recalques. 
A célula é composta por uma bolsa cheia de brita com duas placas de aço no topo, sendo que a inferior, em contato com a bolsa, é furada e a superior é conectada por tubos à superfície. Após o término e limpeza da escavação, a célula é posicionada no fundo, feita a concretagem da estaca e, posteriormente, procedida à injeção de calda de cimento. A finalidade da brita dentro da bolsa é de distribuir a pressão da injeção em toda a área da base da célula.

O esquema da célula é mostrado na Figura 2.45.

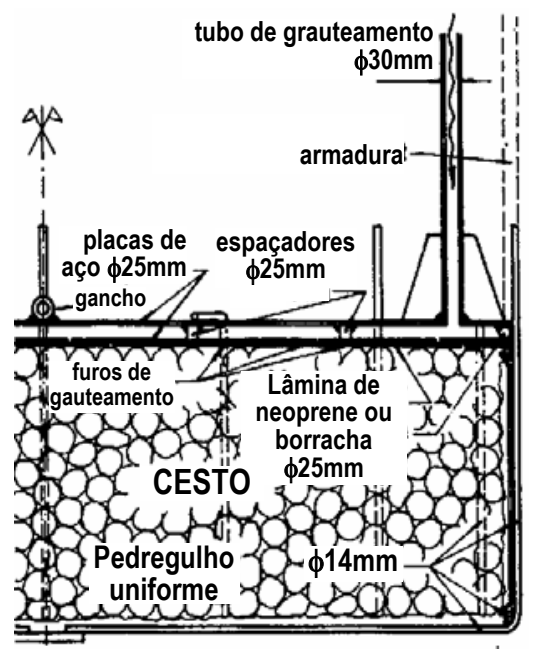

Figura 2.45 - Célula de pré-carga (BOLOGNESI; MORETTO, 1973)

A verificação do comportamento é feita através do acompanhamento do tempo de manutenção de uma pressão pré-estipulada, após estágios de pressão crescentes, até atingir esta pressão. O deslocamento do topo da estaca também é acompanhado.

Os parâmetros para a aprovação das operações são a manutenção de pressão de $10 \mathrm{MPa}$, durante um mínimo de cinco minutos, ou o levantamento de $2 \mathrm{~cm}$ do topo da estaca. Este levantamento raramente acontece, mas também determina a aprovação do serviço.

\subsubsection{8- Célula de pré-carga (LIZZI, 1976)}

Uma variante deste tipo de célula é o equipamento proposto por Lizzi (1976) e mostrado na Figura 2.46. 


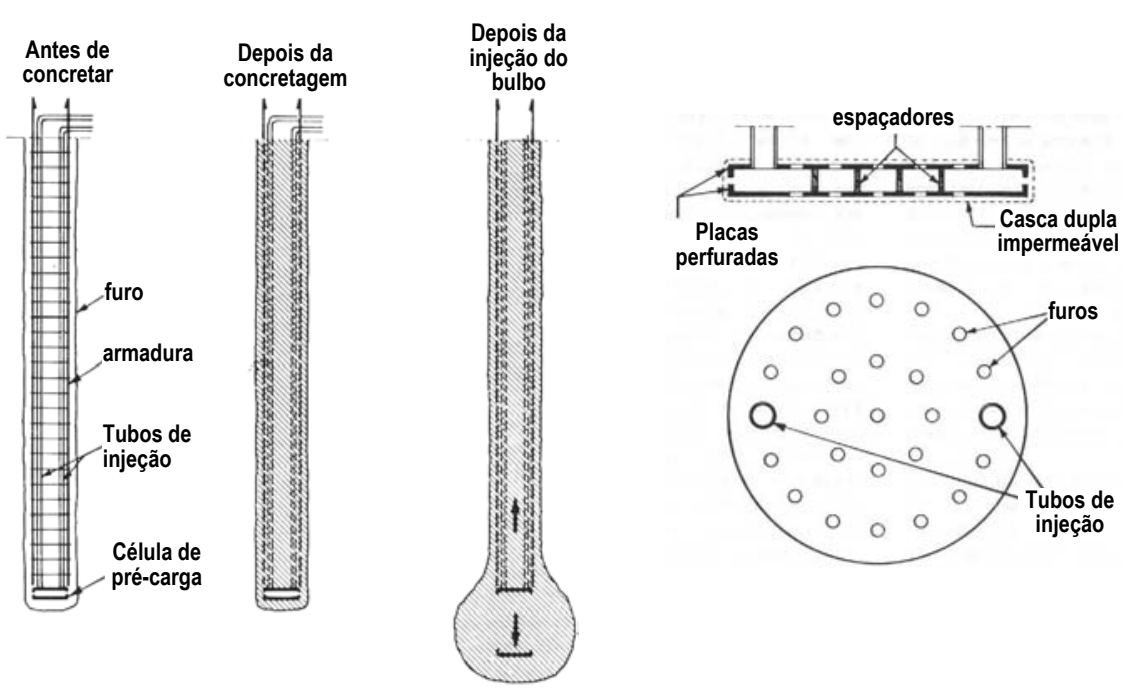

Figura 2.46 - Célula de pré-carga (LIZZI, 1976 e 1988)

As vantagens já foram mencionadas no início e são os aumentos da resistência e da rigidez do solo na ponta da estaca, com o aumento da capacidade de carga e a redução do recalque. As desvantagens são a necessidade de fazer a injeção em várias etapas, com intervalo de tempo entre elas e o consumo elevado de cimento nas injeções. No caso estudado há o relato de consumos variando entre 500 e $6.000 \mathrm{~kg}$ de cimento.

\subsubsection{9- Célula de pré-carga (Sistema Bauer, 1997)}

O sistema Bauer é, também, baseado na injeção de calda na base da estaca, de forma orientada e controlada.

Tomlinson (1997) descreve o sistema relatando:

“Depois de terminada a escavação, ...., a gaiola da armadura é descida até o fundo do furo. No fundo da gaiola, as barras são soldadas à uma placa circular. Uma folha de metal flexível cobre todo o lado inferior desta placa. Um tubo de injeção de graute é conectado ao espaço entre a placa e a folha e um anel periférico de graute é anexado às barras da armadura em uma determinada altura acima da base da estaca. Todos os tubos de graute são 
estendidos até a unidade de medida e bombeamento, na superfície do terreno. A estaca é, então, concretada. Após um período de espera para endurecer o cimento, o graute é injetado dentro dos tubos periféricos de injeção com o objetivo de selar a parte inferior do fuste da estaca para o solo circunvizinho. Após um período de poucos dias para permitir o endurecimento do graute, o espaço entre a placa de metal e a folha de metal é injetado com graute, sob alta pressão. A subida da placa metálica é resistida pela tensão no selo de solo e graute no fuste, e o solo próximo à folha metálica é, então, comprimido. A altura do grauteamento periférico acima da base da estaca depende da pressão requerida na base, assim como da resistência de ponta de projeto da estaca".

Yeats e Riordan (1989) descrevem uma aplicação desta técnica nas fundações de um edifício público em Londres, sobre a areia densa de Thanet. A fundação era composta por estacas escavadas com lama bentonítica com 38,2 metros de comprimento, com 2,7 metros dentro da areia densa. Foram usados quatro circuitos de graute, com manchetes (Figura 2.47).

O cálculo do valor absoluto da pressão na base depende da adesão do fuste. Tal como nas proposições anteriores, o deslocamento da ponta da estaca e o atrito lateral são inferidos com base nos parâmetros elásticos da estaca. 


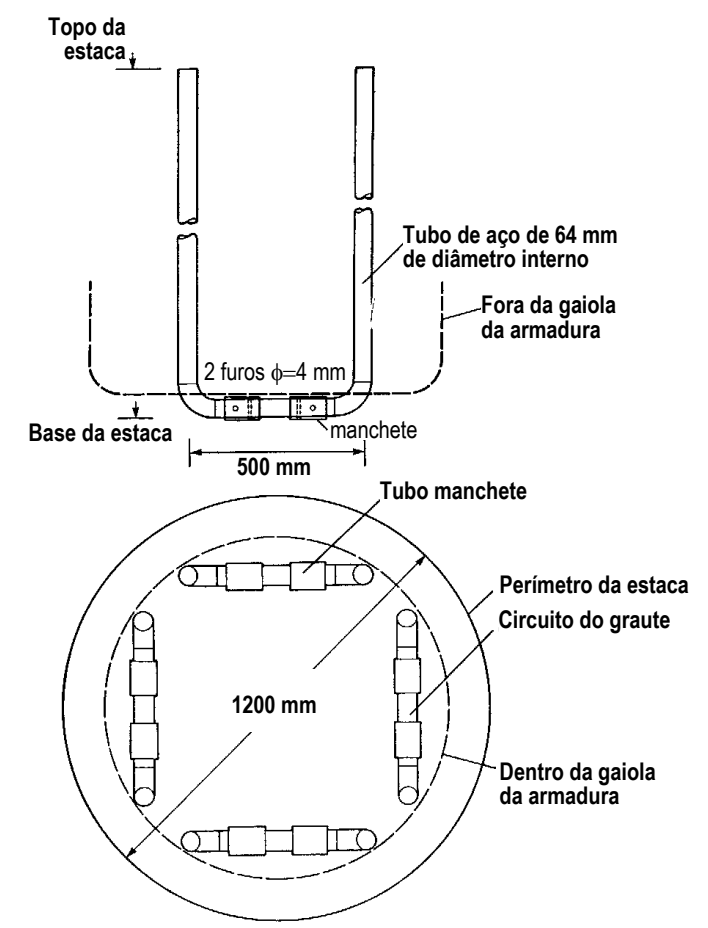

Figura 2.47 - Sistema BAUER de grauteamento da base (YEATS; RIORDAN, 1989)

A vantagem principal é a simplicidade da célula em relação ao sistema proposto por Bolognesi e Moretto (1973).

\subsubsection{0- Célula Expansiva Hidrodinâmica (SILVA, 1983)}

Silva (1983) desenvolveu um sistema caracterizado por uma célula de pré-carga no fundo da escavação, juntamente com um equipamento para a sua monitoração.

Outra variante deste tipo de célula é o sistema proposto por Silva (1983), denominado Célula Expansiva Hidrodinâmica (Expancell) e mostrado na Figura 2.48.

A principal diferença com os sistemas anteriores é que a finalidade principal deste sistema é a de funcionar como uma prova de carga onde a reação é o fuste da estaca que está sendo ensaiada, com a possibilidade de separação das resistências de ponta e de atrito lateral. Isto é feito com o uso de monitoração dos deslocamentos do topo, por meio direto e da ponta, 
através de um dispositivo desenvolvido especialmente para este fim e denominado de gradiente hidráulico (Figura 2.49).
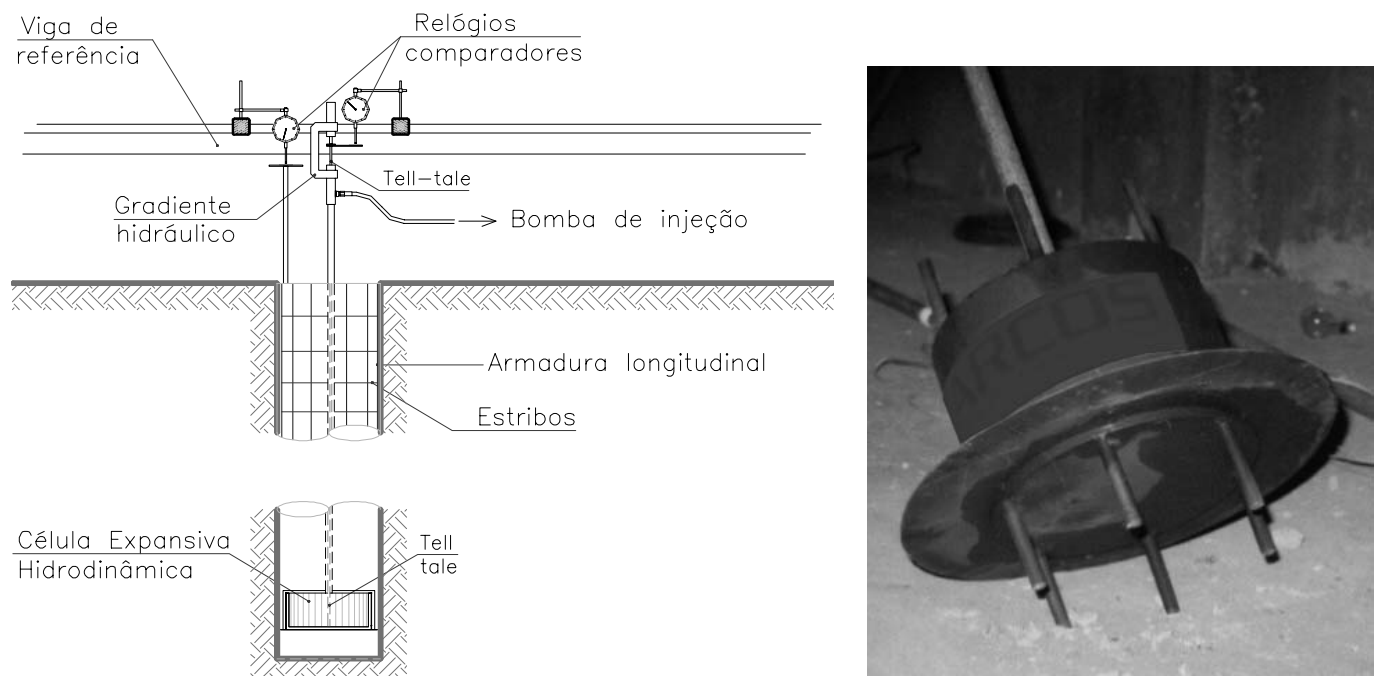

Figura 2.48 - Expancell - Vista geral do sistema e detalhe da célula

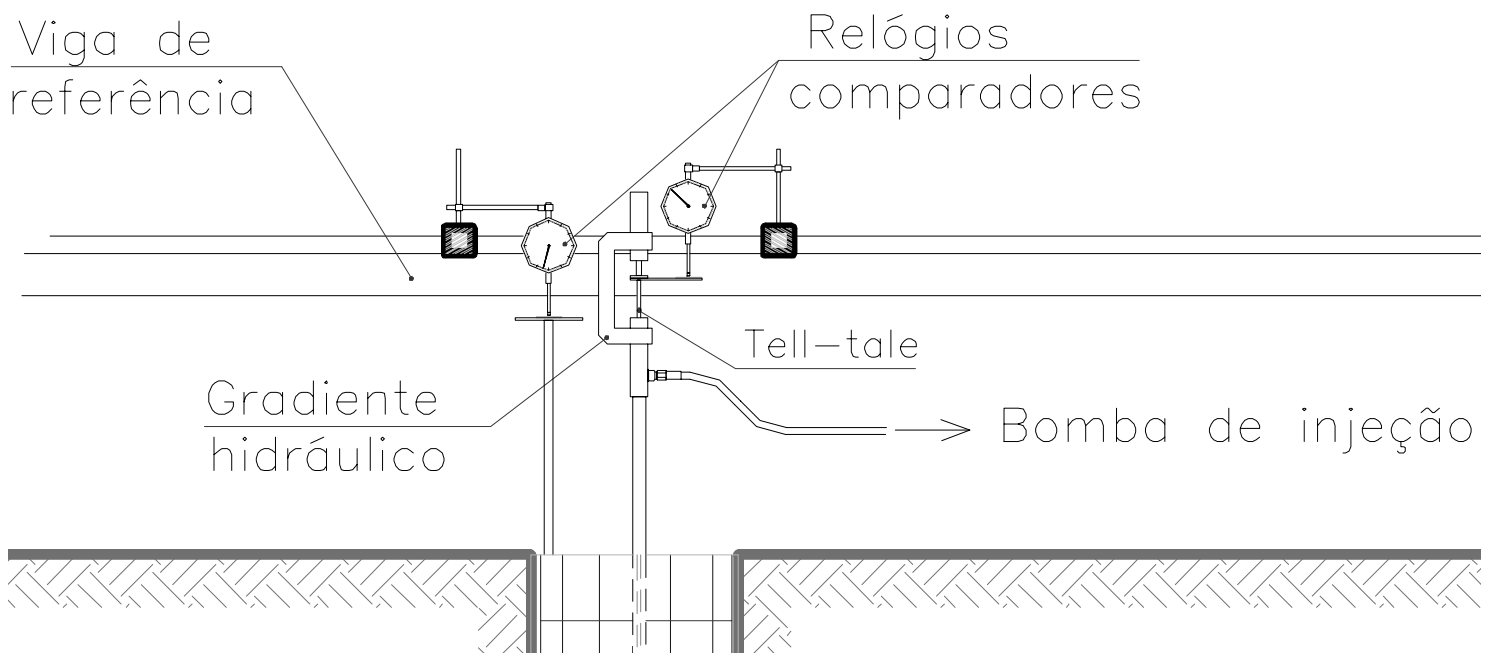

Figura 2.49 - Detalhe do gradiente hidráulico

Apesar da finalidade principal não ser a melhoria da resistência de ponta de estacas, isto pode ser atingido com o uso de equipamento com curso maior, uma vez que os equipamentos podem ser fabricados especificamente para cada situação.

A vantagem principal é que o deslocamento da ponta é medido diretamente, o que permite a separação das parcelas de atrito lateral e resistência da ponta. 


\subsection{2- Conclusão}

A estaca ideal deveria ser do tipo de deslocamento, moldada in situ, com a interpretação da sua instalação, e possibilitando intervenção, tanto na ponta, quanto no fuste.

A aptidão natural das estacas é apresentar a maior parcela de resistência por atrito lateral, devido à sua geometria. Desta forma, todas as técnicas de melhoria da capacidade de carga de estacas são mais eficazes em relação ao atrito lateral. No entanto, em muitas situações, a ponta da estaca está apoiada em solo tão mais resistente que os solos superficiais, que a resistência de ponta disponível pode apresentar uma parcela importante da capacidade de carga.

$\mathrm{Na}$ busca deste objetivo, dois caminhos podem ser adotados: evitar que o processo de instalação piore as características naturais do solo e desenvolver processos que permitam melhorar estas características. As possíveis intervenções para a melhoria das propriedades geotécnicas, após a permissão de certa deterioração, são a remoção dos detritos acumulados, a introdução de equipamentos que desloquem e comprimam o solo, com preenchimento do espaço criado com material estrutural ou, simplesmente, introduzir material estrutural no solo, através de injeções.

Atualmente, a quase totalidade dos métodos e equipamentos está voltada para as estacas de grandes dimensões, existindo uma lacuna no segmento de estacas de pequenas dimensões. 


\section{3- CARACTERÍSTICAS DO CAMPO EXPERIMENTAL DA UEL}

A área onde foi feita a pesquisa denomina-se Campo Experimental de Engenharia Geotécnica Professor Saburo Morimoto (CEEG), tem $2.975 \mathrm{~m}^{2}$ (dois mil e novecentos e setenta e cinco metros quadrados) e está localizada no campus universitário da Universidade Estadual de Londrina (Figura 3.1). Os experimentos se desenvolveram nas áreas de pesquisa 4 e 5, próximas aos furos SP3, SP4 e SP8 (Figura 3.2).

Os resultados apresentados a seguir são frutos das campanhas de investigação que precederam a execução das estacas desta pesquisa. A finalidade da apresentação destes dados foi a de permitir uma visão geotécnica mais abrangente possível da área da pesquisa, mesmo que alguns deles não tenham sido diretamente utilizados nas análises. A pesquisa gerou resultados adicionais a esta campanha de investigação geotécnica e que serão apresentados no Capítulo 5 - Resultados: Apresentação e análise.

\section{1- Geotecnia local}

A geologia da região é caracterizada por extensos derrames de basalto da Formação Serra Geral, ou seja, situa-se na área central da Bacia Sedimentar do Paraná e o solo sobrejacente à rocha é de origem residual. 


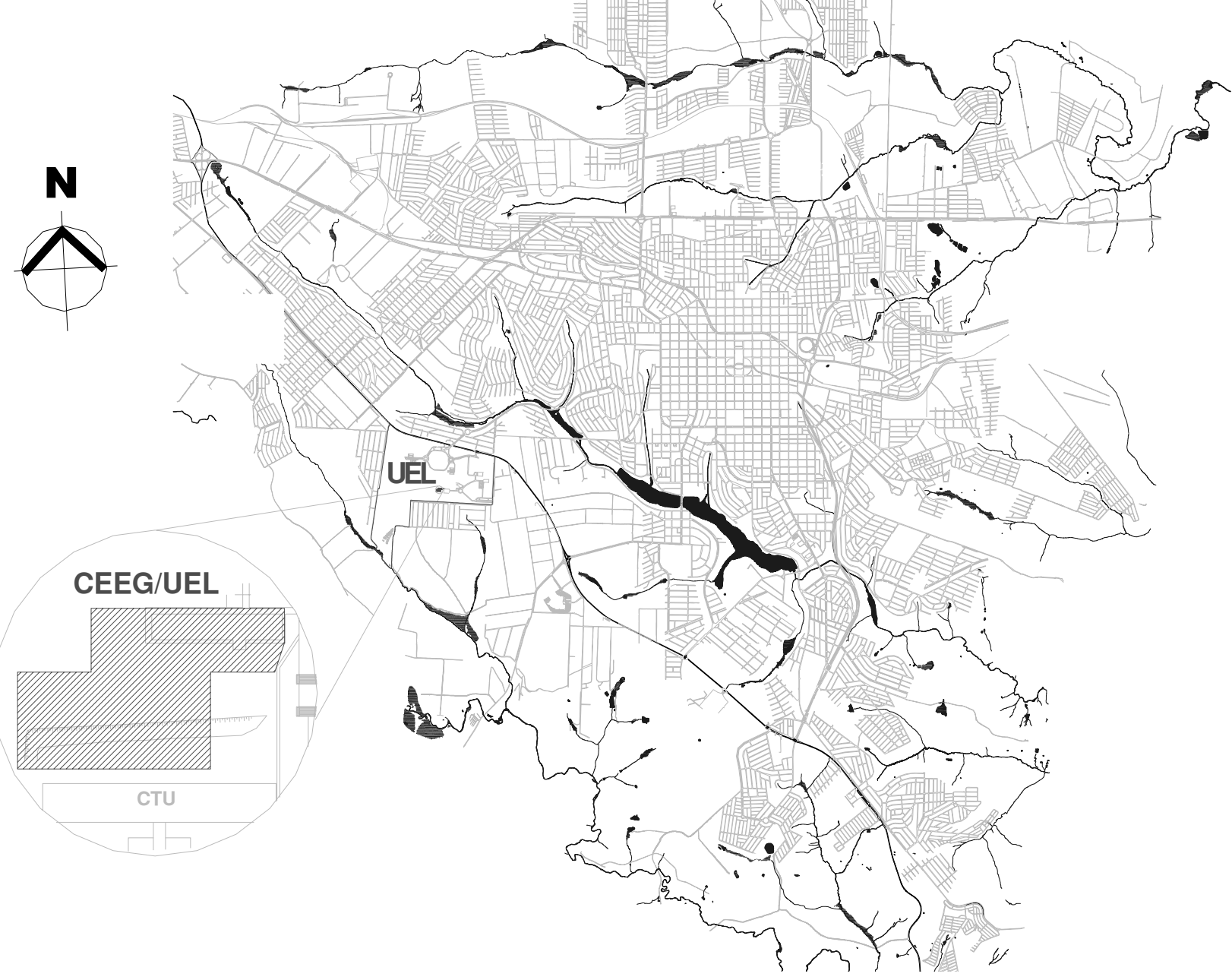

Figura 3.1 - Mapa de Londrina e a localização do CEEG 


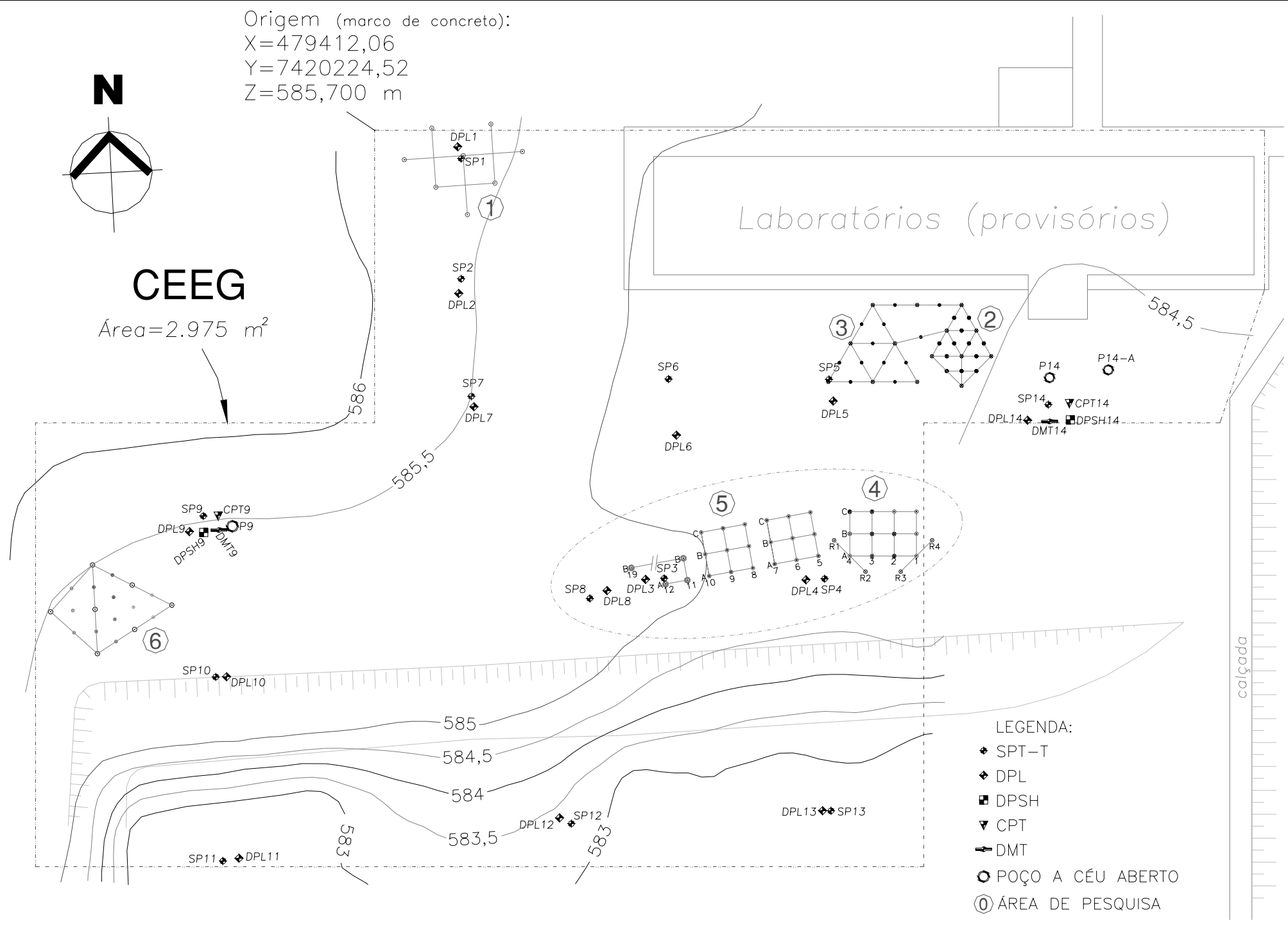

Figura 3.2 - Área do CEEG com a locação das campanhas de investigação do subsolo e das áreas de pesquisas 
O perfil geotécnico característico é constituído por um horizonte superficial evoluído (horizonte B), bastante poroso e com fortes características de solo laterítico, com espessura de cerca de $10 \mathrm{~m}$, seguido de um horizonte com características de solo residual, com estrutura reliquiar do basalto, inicialmente em grau muito leve a moderado, ficando mais evidente com a profundidade. Finalmente, está presente o horizonte de rocha alterada, com graus de alteração decrescentes com a profundidade, sobrejacente à rocha sã.

A campanha de sondagem de simples reconhecimento, com SPT-T, confirmou a existência destes três horizontes principais. A determinação das características geotécnicas principais foi feita através de ensaios in situ complementares e em laboratório, descritos a seguir.

\subsection{1- Ensaios In Situ}

As investigações e ensaios in situ iniciaram em 18 de setembro de 1997 e se constituíram de campanhas de SPT-T (Standard Penetration Test with Torque Measurement), poços de inspeção e coleta de amostras indeformadas, DPL (Dynamic Probe Light), DPSH (Dynamic Probe Super Heavy), CPT (Cone Penetration Test), DMT (DilatoMeter Test) e ensaio de permeabilidade in situ, no estrato superficial.

O resumo destas campanhas está apresentado na Tabela 3.1.

Tabela 3.1 - Resumo dos ensaios in situ

\begin{tabular}{|c|c|c|c|c|c|c|}
\hline \multirow{2}{*}{$\begin{array}{c}\text { tipo de } \\
\text { investigação }\end{array}$} & \multirow{2}{*}{$\begin{array}{l}\text { quant. } \\
\text { de furos }\end{array}$} & \multicolumn{2}{|c|}{ datas } & \multicolumn{3}{|c|}{ profundidades (m) de perfuração } \\
\hline & & início & término & mínima & máxima & total \\
\hline SPT-T & 14 & $18 / 09 / 1997$ & $02 / 04 / 1999$ & $12,45(\mathrm{SP} 2)$ & 26,15 (SP5) & $266,84 \mathrm{~m}$ \\
\hline poço a céu aberto & 2 & $19 / 08 / 1998$ & $05 / 10 / 1998$ & $16,90(\mathrm{P} 14)$ & $21,90(\mathrm{P9})$ & $38,80 \mathrm{~m}$ \\
\hline DPL & 14 & $08 / 06 / 1999$ & $10 / 06 / 1999$ & 10,00 & 17,90 (DPL9) & $173,60 \mathrm{~m}$ \\
\hline DPSH & 2 & $09 / 06 / 1999$ & 09/06/1999 & 14,27 (DPSH9) & 15,12 (DPSH14) & $29,39 \mathrm{~m}$ \\
\hline $\mathrm{CPT}$ & 2 & $09 / 06 / 1999$ & 09/06/1999 & 18,675 (CPT14) & 19,950 (СРТ9) & $38,63 \mathrm{~m}$ \\
\hline DMT & 2 & $09 / 06 / 1999$ & 09/06/1999 & 16,40 (DMT14) & 16,60 (DMT9) & $33,00 \mathrm{~m}$ \\
\hline permeab. in situ & 1 & $21 / 09 / 2004$ & $21 / 09 / 2004$ & 1,00 & 1,00 & $1,00 \mathrm{~m}$ \\
\hline
\end{tabular}


(a) Sondagem de simples reconhecimento com SPT-T

Foram executados 14 furos de sondagem de simples reconhecimento com SPT-T, segundo a NBR-6484 (1997) e conforme resumo mostrado na Tabela 3.2. A Figura 3.3 mostra uma vista parcial do CEEG, com duas equipes de sondagem em operação. A equipe na parte da frente da foto é formada por funcionários da UEL e a do fundo é de uma empresa particular da cidade.

Tabela 3.2 - Resumo dos furos de SPT-T

\begin{tabular}{|c|c|c|c|c|c|c|c|c|c|c|c|c|c|c|}
\hline Furo & SP1 & SP2 & SP3 & SP4 & SP5 & SP6 & SP7 & SP8 & SP9 & SP10 & SP11 & SP12 & SP13 & SP14 \\
\hline Data & $28 / 09 / 97$ & $03 / 10 / 97$ & $21 / 10 / 97$ & $04 / 11 / 97$ & $25 / 03 / 99$ & $10 / 12 / 97$ & $21 / 06 / 98$ & $03 / 07 / 98$ & $02 / 07 / 98$ & $21 / 08 / 98$ & $23 / 04 / 99$ & $15 / 03 / 99$ & $20 / 04 / 99$ & $28 / 04 / 99$ \\
\hline $\mathrm{X}(\mathrm{m})$ & 5,74 & 5,29 & 17,88 & 28,7 & 29,73 & 18,91 & 5,55 & 4,44 & $-12,97$ & $-12,72$ & $-12,92$ & 10,72 & 28,28 & 44,43 \\
\hline $\mathrm{Y}(\mathrm{m})$ & $-2,23$ & $-10,35$ & $-31,31$ & $-31,92$ & $-18,49$ & $-17,87$ & $-18,3$ & $-33,45$ & $-25,41$ & $-36,31$ & $-48,76$ & $-47,52$ & $-47,61$ & $-20,99$ \\
\hline $\mathrm{Z}(\mathrm{m})$ & 585,32 & 585,4 & 585,26 & 584,98 & 584,56 & 584,84 & 585,46 & 585,28 & 585,54 & 585,15 & 582,95 & 583,32 & 582,95 & 584,19 \\
\hline N.A.(m) & $\mathrm{NE}$ & $\mathrm{NE}$ & $\mathrm{NE}$ & $\mathrm{NE}$ & 563,06 & $\mathrm{NE}$ & $\mathrm{NE}$ & $\mathrm{NE}$ & 565,64 & $\mathrm{NE}$ & 564,15 & 562,82 & 561,78 & $\mathrm{NE}$ \\
\hline Prof.(m) & 17,45 & 12,45 & 17,47 & 15,45 & 26,15 & 15,45 & 16,46 & 16,46 & 24,4 & 16,45 & 20,45 & 25,28 & 21,47 & 21,45 \\
\hline NE=Não encontrado & \multicolumn{10}{|c|}{ Total perfurado $=266,84 \mathrm{~m}$} \\
\hline
\end{tabular}

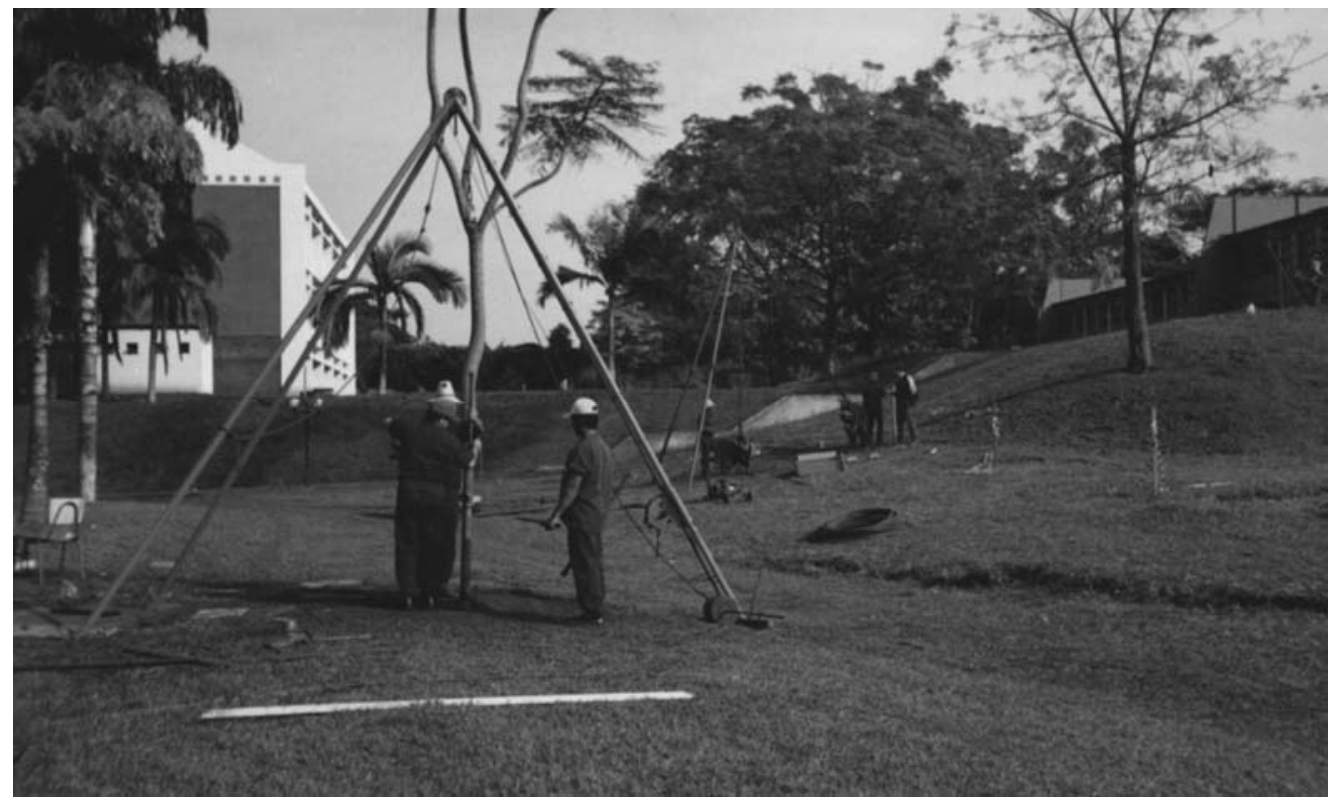

Figura 3.3 - Execução dos furos SP3 (frente) e SP9 (fundo)

Alguns furos atingiram profundidades maiores e, portanto, os perfis representados a seguir aparecem interrompidos no trecho entre os furos de sondagem com profundidades inferiores as dos seus vizinhos. As Figuras 3.4 e 3.5 mostram os perfis obtidos nas direções Oeste-Leste e Sul-Norte, respectivamente do fundo para frente e da esquerda para a direita, na Figura 3.3. 


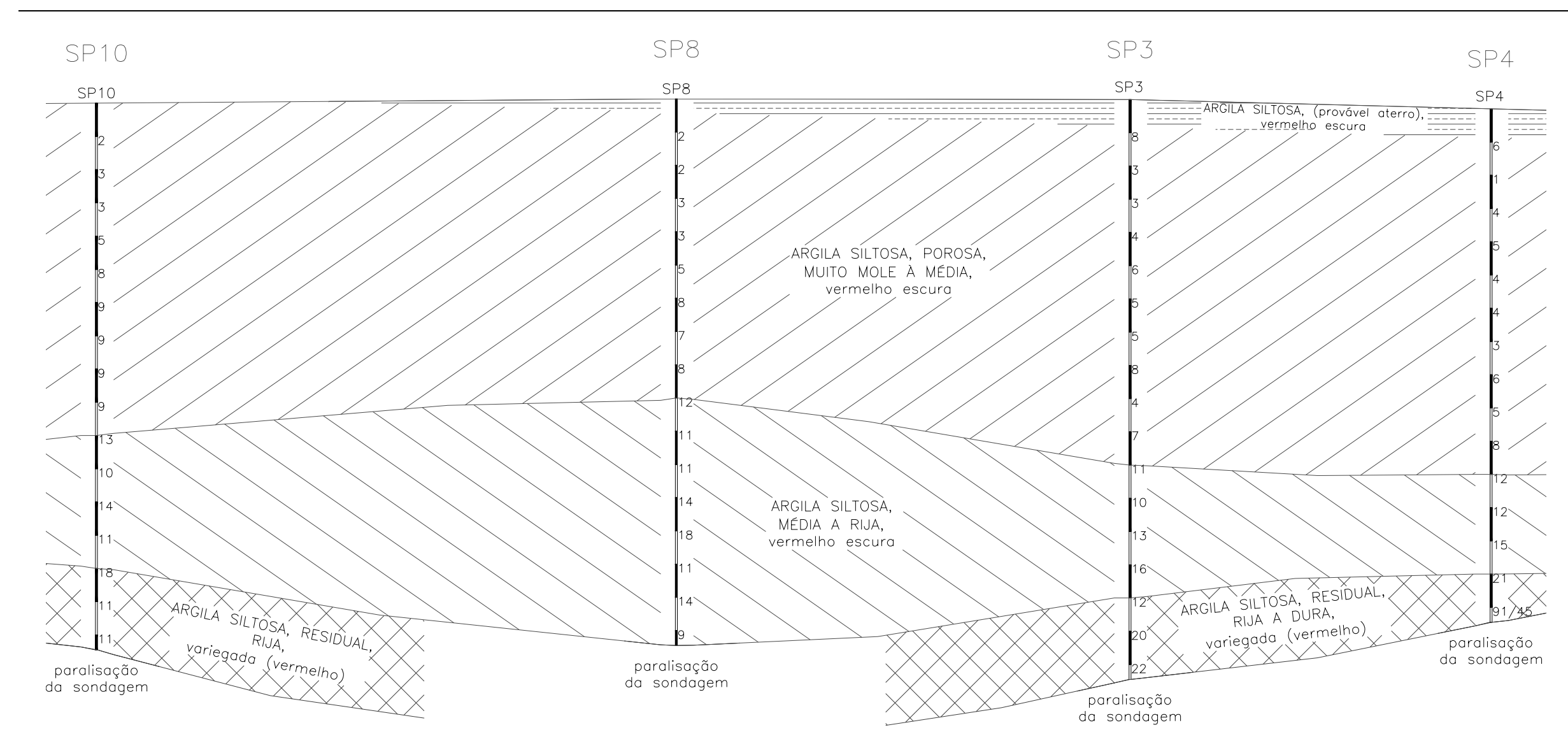

Figura 3.4 - Perfil (W-E) obtido na sondagem de simples reconhecimento com SPT 


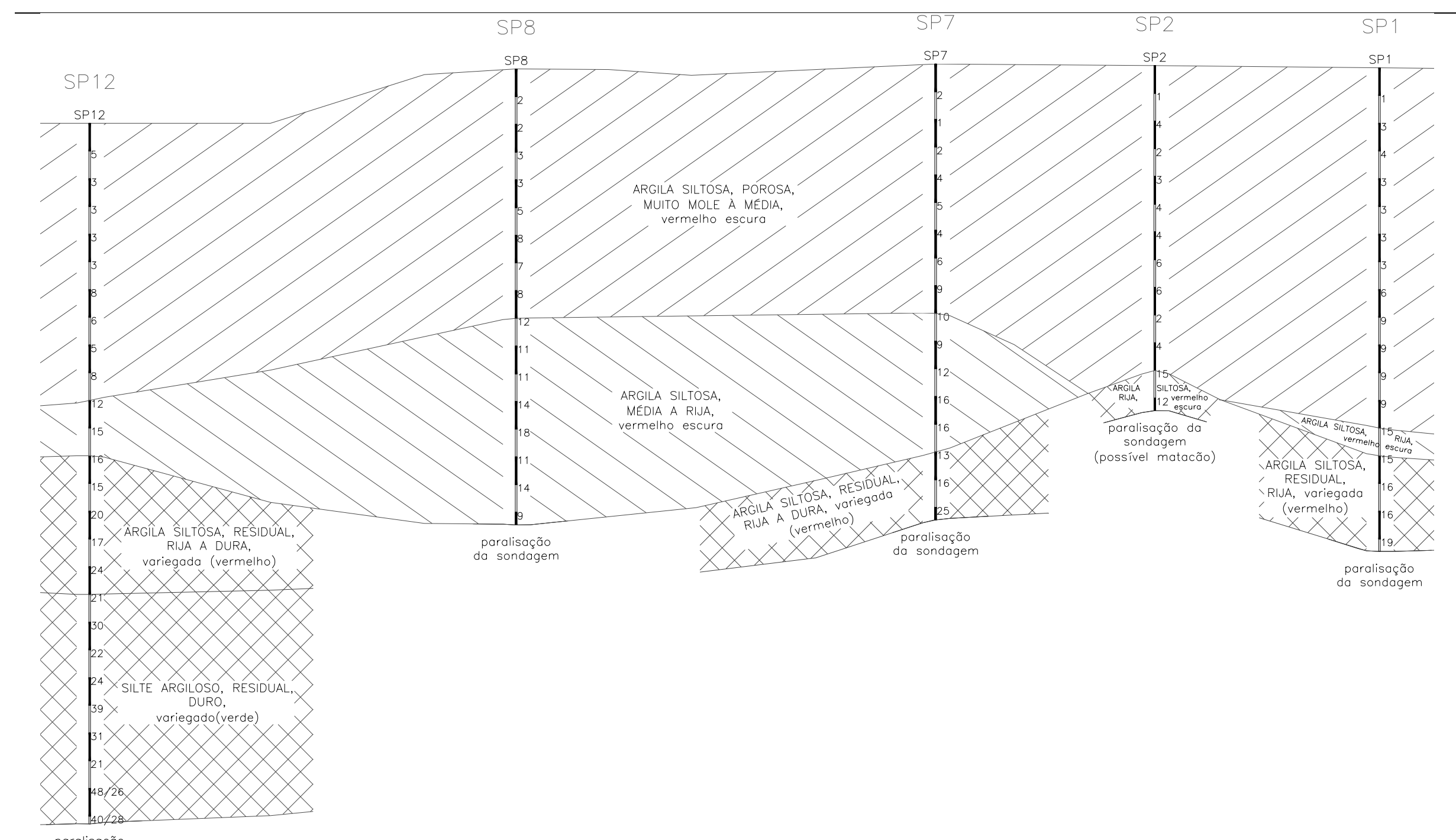

paralisação

Figura 3.5 - Perfil (S-N) obtido na sondagem de simples reconhecimento com SPT 
A Figura 3.6 mostra os valores médios dos $\mathrm{N}$, dos $\mathrm{T}_{\text {máx }}$ e dos respectivos desvios padrão e coeficientes de variação obtidos.

\begin{tabular}{|c|c|c|c|c|c|c|}
\hline $\begin{array}{c}\text { prof } \\
(\mathrm{m})\end{array}$ & \multicolumn{3}{|c|}{$\mathrm{SPT}$} & \multicolumn{3}{|c|}{ Torque máximo } \\
\cline { 2 - 7 } & $\mathrm{N}_{\text {médio }}$ & $\mathrm{S}$ & $\mathrm{CV}$ & $\mathrm{T}_{\text {médio }}$ & $\mathrm{S}$ & $\mathrm{CV}$ \\
\hline 0,00 & 0,00 & 0,00 & 0,00 & 0,00 & 0,00 & 0,00 \\
\hline 1,45 & 2,64 & 1,91 & 0,72 & 3,17 & 3,66 & 1,16 \\
\hline 2,45 & 2,86 & 1,03 & 0,36 & 3,33 & 3,37 & 1,01 \\
\hline 3,45 & 3,29 & 0,99 & 0,30 & 3,23 & 2,42 & 0,75 \\
\hline 4,45 & 4,00 & 1,00 & 0,25 & 3,25 & 2,01 & 0,62 \\
\hline 5,45 & 5,21 & 1,42 & 0,27 & 4,00 & 2,55 & 0,64 \\
\hline 6,45 & 5,86 & 1,75 & 0,30 & 5,08 & 2,99 & 0,59 \\
\hline 7,45 & 6,29 & 1,86 & 0,30 & 5,77 & 3,24 & 0,56 \\
\hline 8,45 & 7,93 & 1,69 & 0,21 & 7,58 & 2,87 & 0,38 \\
\hline 9,45 & 8,79 & 2,81 & 0,32 & 8,23 & 4,34 & 0,53 \\
\hline 10,45 & 10,43 & 2,74 & 0,26 & 11,57 & 7,08 & 0,61 \\
\hline 11,45 & 12,21 & 2,15 & 0,18 & 13,43 & 5,15 & 0,38 \\
\hline 12,45 & 12,86 & 3,90 & 0,30 & 14,36 & 5,46 & 0,38 \\
\hline 13,45 & 14,69 & 3,66 & 0,25 & 15,31 & 5,51 & 0,36 \\
\hline 14,45 & 15,92 & 5,59 & 0,35 & 20,42 & 8,01 & 0,39 \\
\hline 15,45 & 20,00 & 11,14 & 0,56 & 28,08 & 11,06 & 0,39 \\
\hline 16,45 & 19,58 & 6,36 & 0,32 & 30,09 & 9,08 & 0,30 \\
\hline 17,45 & 21,56 & 5,79 & 0,27 & 31,75 & 8,29 & 0,26 \\
\hline 18,45 & 16,43 & 9,78 & 0,60 & 24,33 & 9,67 & 0,40 \\
\hline 19,45 & 18,24 & 5,01 & 0,27 & 25,67 & 7,09 & 0,28 \\
\hline 20,45 & 18,43 & 6,00 & 0,33 & 27,33 & 10,01 & 0,37 \\
\hline 21,45 & 25,50 & 8,78 & 0,34 & 33,60 & 8,17 & 0,24 \\
\hline 22,45 & 31,33 & 6,51 & 0,21 & 40,00 & 0,00 & 0,00 \\
\hline 23,45 & 24,33 & 3,06 & 0,13 & 36,67 & 4,16 & 0,11 \\
\hline 24,45 & 60,00 & 0,00 & 0,00 & 40,00 & 0,00 & 0,00 \\
\hline 25,45 & 60,00 & 0,00 & 0,00 & 40,00 & 0,00 & 0,00 \\
\hline 26,45 & 60,00 & 0,00 & 0,00 & 40,00 & 0,00 & 0,00 \\
\hline
\end{tabular}

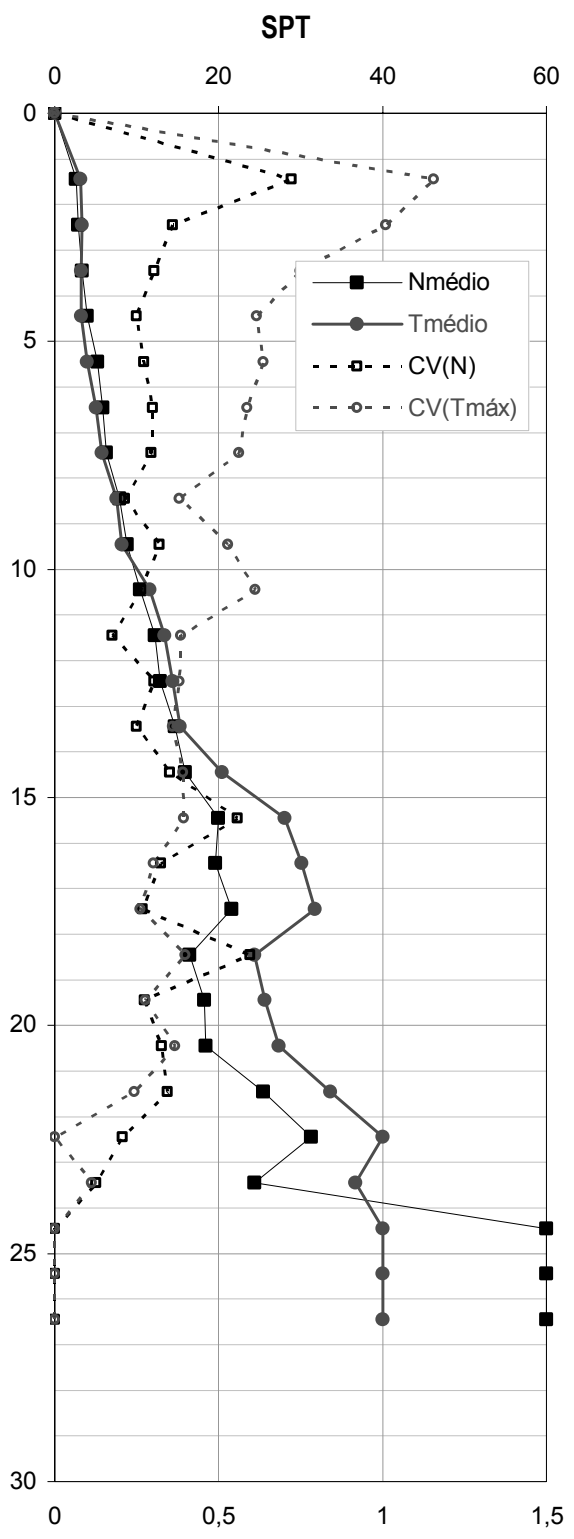

Figura 3.6 - Resultados dos SPTs

O elevado coeficiente de variação $(70 \%)$ no primeiro metro provavelmente é decorrente de processos de compactação, ressecamento e da imprecisão natural na medida do $\mathrm{N}$, através de números inteiros. Abaixo deste ponto, até a profundidade de $13 \mathrm{~m}$, mantém-se próxima a $25 \%$, apresentando picos próximos de $60 \%$ entre 15 e $18 \mathrm{~m}$, provavelmente devido ao caráter 
residual do solo e decaindo para valores abaixo de $15 \%$ após os $23 \mathrm{~m}$, devido à diminuição de dados para a análise estatística.

\section{(b) Poços de inspeção e coleta de amostras indeformadas}

Foram abertos dois poços para a inspeção do perfil e a coleta de blocos de amostras indeformadas, conforme locação mostrada na Figura 3.2. O poço P9 (Figura 3.9) foi escavado entre os dias 19 de agosto e 17 de setembro de 1998, até os 21,90 m de profundidade, quando atingiu o N.A.. O poço P14 (Figuras 3.7 e 3.8) foi escavado entre os dias 18 de setembro e 5 de outubro de 1998, até os 21,90 m de profundidade e não atingiu o N.A..

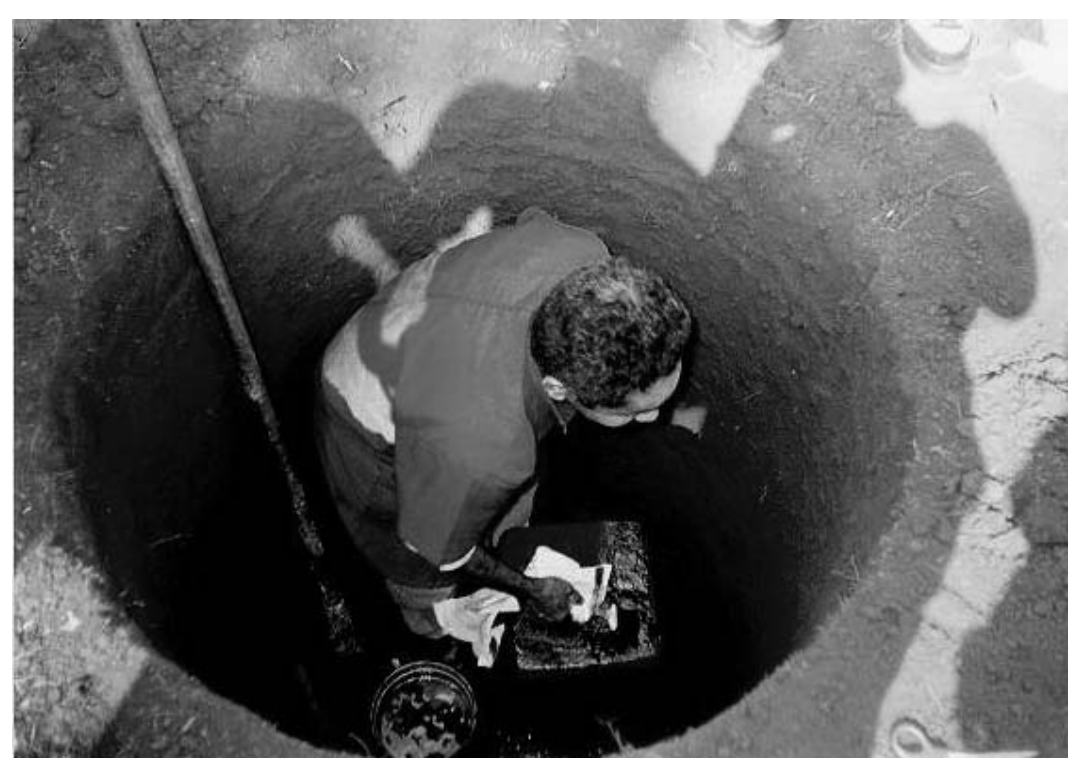

Figura 3.7 - Coleta de amostra indeformada (P14) 


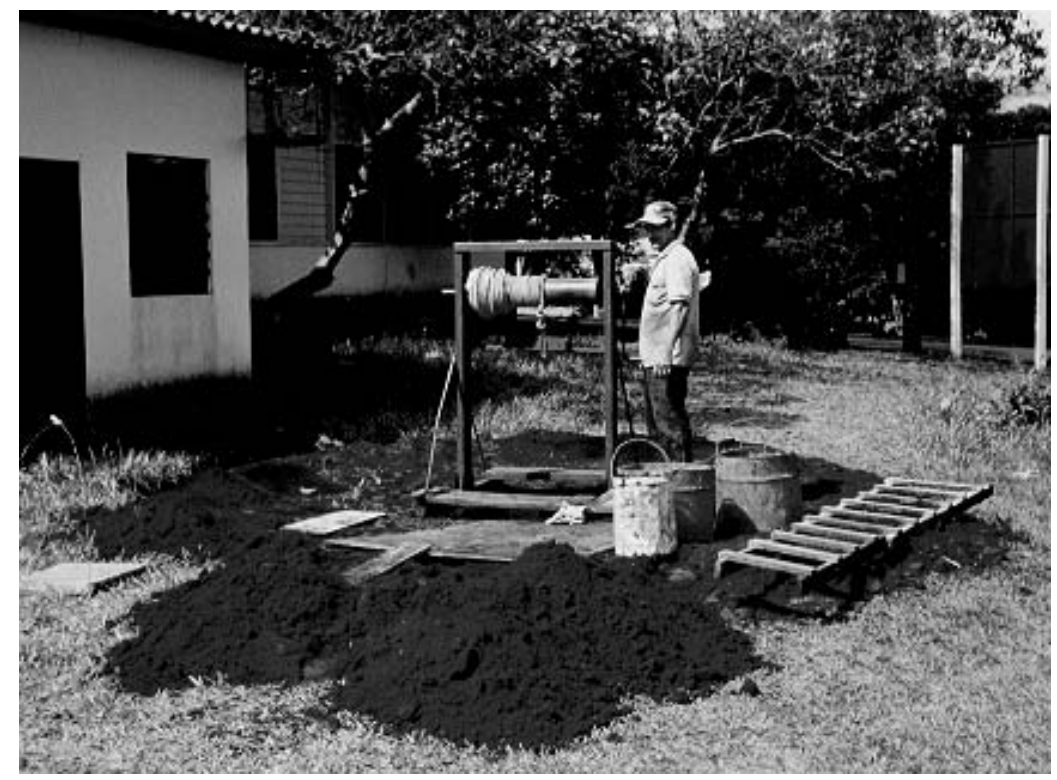

Figura 3.8 - Argila siltosa porosa característica do 1o estrato (P14)

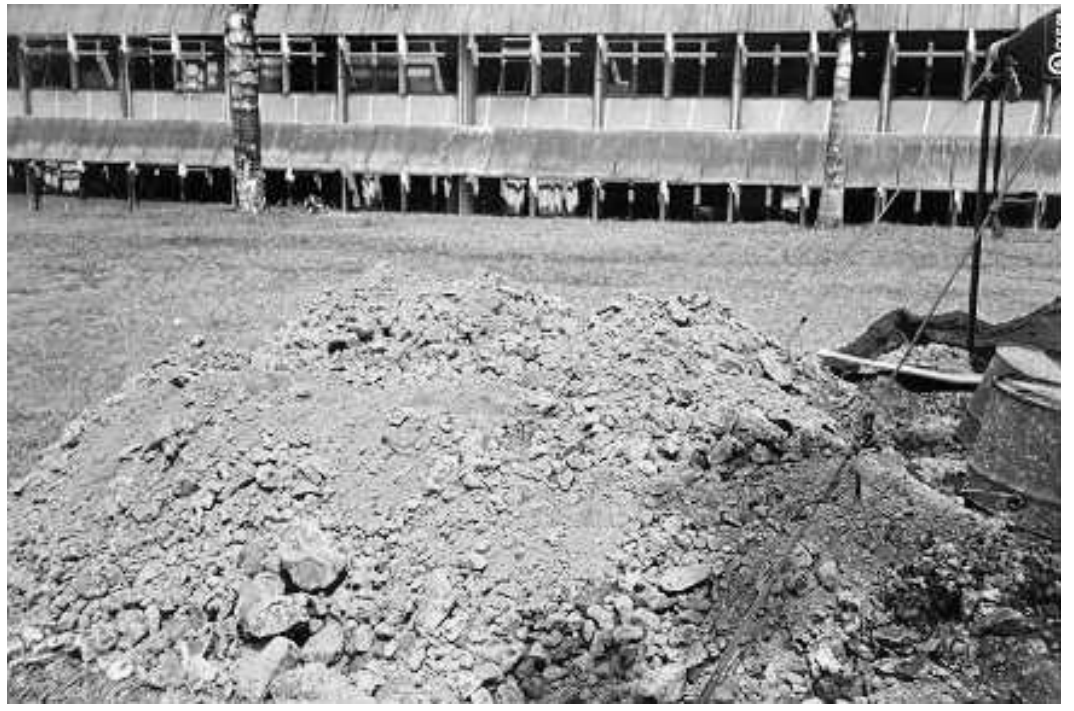

Figura 3.9 - Argila siltosa residual característica do 3 o estrato (P9)

\section{(c) Dynamic Probe Light (DPL)}

Foram executados 14 furos de DPL durante o período de 8 a 10 de junho de 1999. A execução dos ensaios DPL é caracterizada pela cravação contínua, sob golpes de energia constante, de uma haste com ponta fechada, na forma de um cone padronizado, com $10 \mathrm{~cm}^{2}$ de área. A energia aplicada corresponde à queda de um martelo, com massa de $10 \mathrm{~kg}$, de uma altura de 50 centímetros e o número de golpes é anotado a cada 10 centímetros de penetração. 
A Figura 3.10 mostra a equipe de sondagem em operação no furo DPL1 e a Figura 3.11 mostra os valores médios dos DPLs, dos desvios padrão e dos coeficientes de variação obtidos.

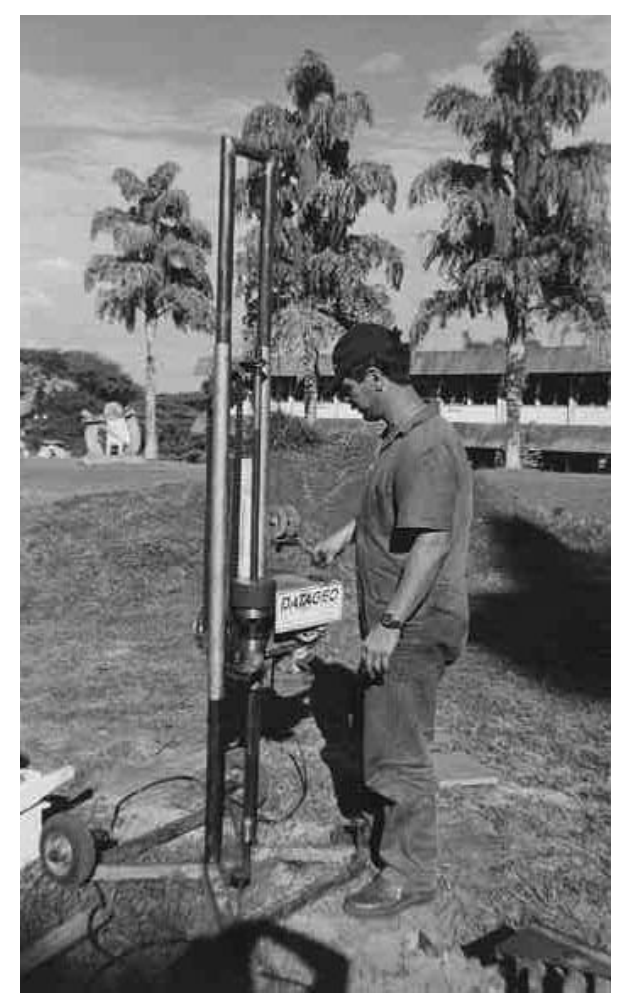

Figura 3.10 - Execução do DPL1

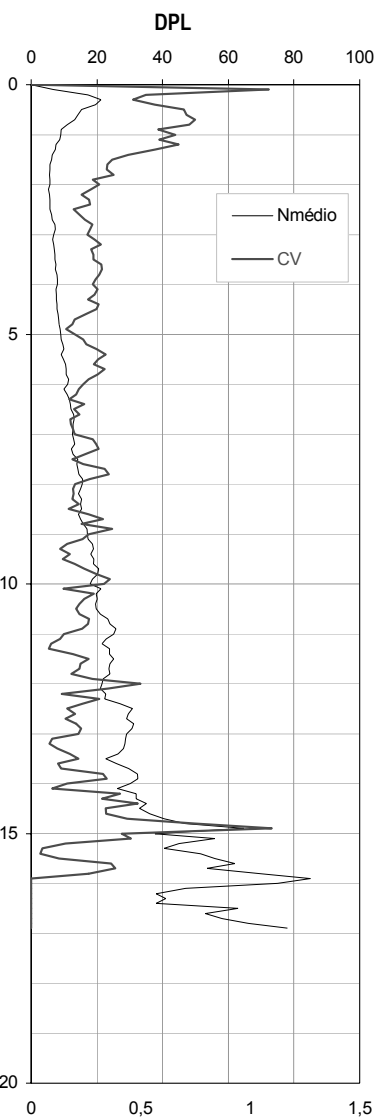

Figura 3.11 - Resultados dos DPLs

O comportamento dos coeficientes de variação com a profundidade foi conceitualmente o mesmo daquele do SPT, confirmando a tendência observada.

\section{(d) Dynamic Probe Super Heavy (DPSH)}

Foram executados dois furos de DPSH no dia 9 de junho de 1999. A execução dos ensaios DPSH é idêntica à dos ensaios DPL, porém os diâmetros das hastes e do cone são maiores e a energia aplicada corresponde à altura de queda de um martelo, com massa de 63,5 kg, de uma altura de 75 centímetros. O número de golpes é anotado a cada 20 centímetros de penetração. 
A Figura 3.12 mostra a equipe de sondagem em operação no furo DPSH9 e a Figura 3.13 mostra os resultados médios, para cada metro, dos DPSHs.

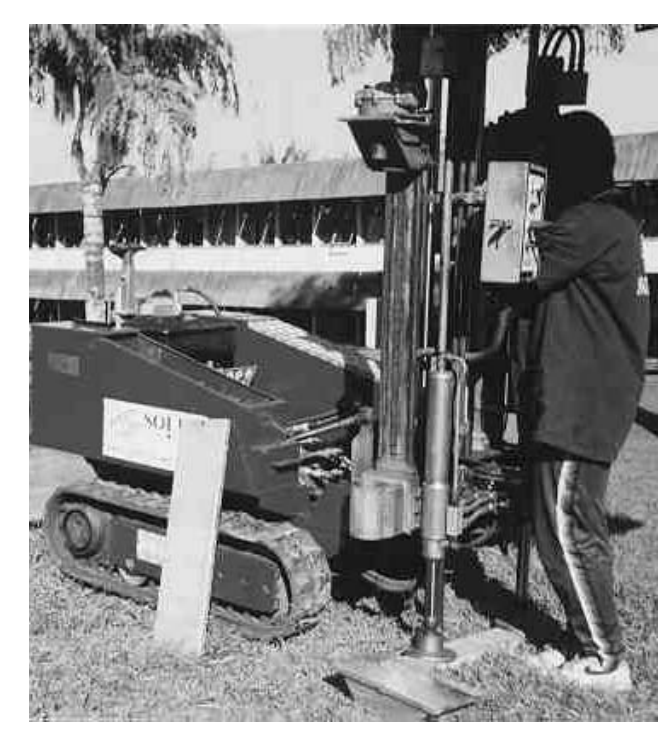

Figura 3.12 - Execução do DPSH9

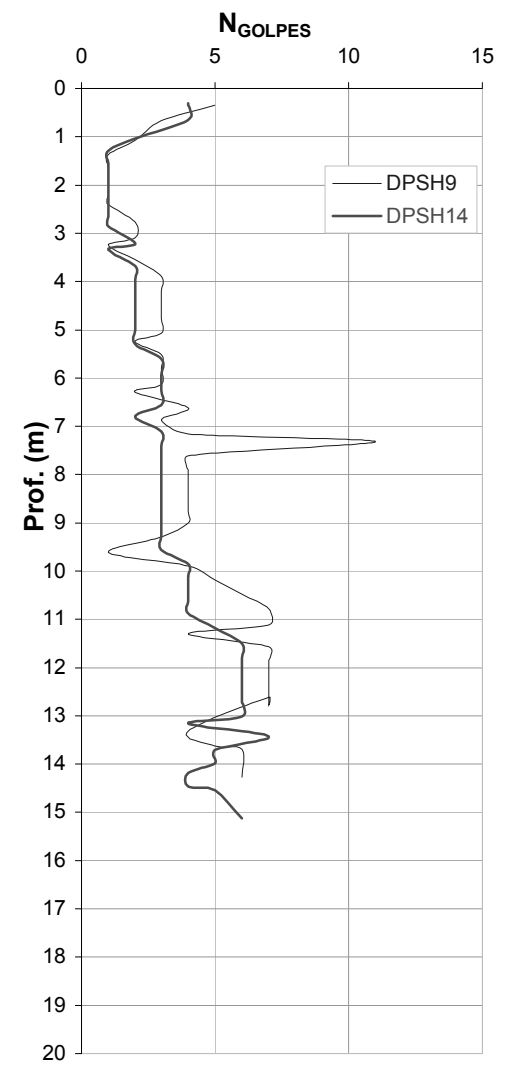

Figura 3.13 - Resultados dos DPSHs

Estes ensaios também mostraram o topo do estrato superficial mais resistente.

\section{(e) Cone Penetration Test (CPT)}

Foram executados dois furos de CPT segundo a MB-3406 (1991), no dia 9 de junho de 1999. Foi utilizado um equipamento hidráulico auto propelido (Figura 3.12) para a cravação estática e um cone elétrico wireless. A Figura 3.14 mostra os valores obtidos nos CPTs.

Os resultados apresentam a mesma tendência geral dos ensaios anteriores, especialmente daqueles mais próximos destes dois furos. 


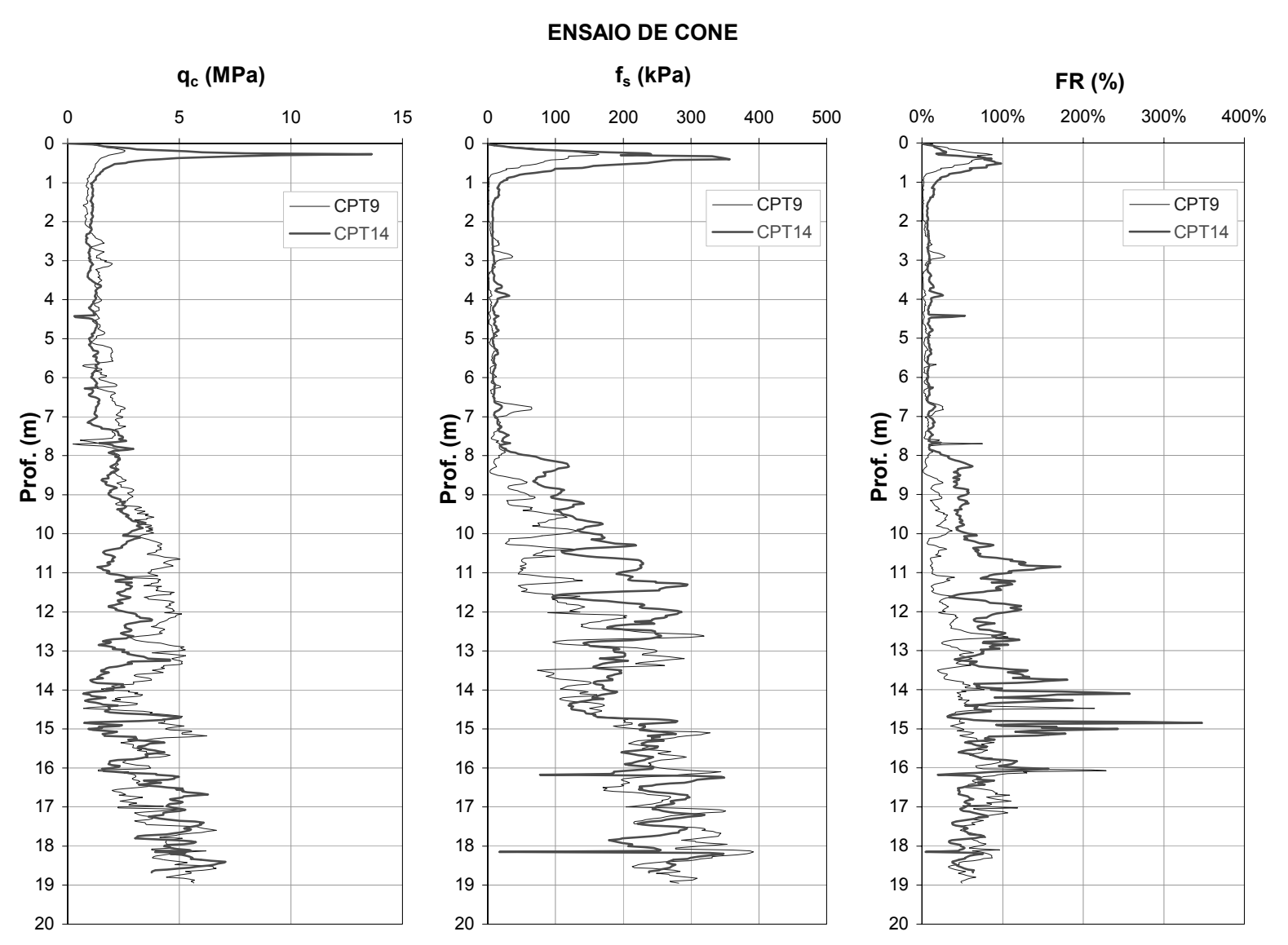

Figura 3.14 - Resultados dos CPTs

Estes ensaios também mostraram a maior resistência no topo do estrato superficial, que foi classificado como silte arenoso a argiloso.

\section{(f) DilatoMeter Test (DMT)}

Foram executados, no dia 9 de junho de 1999, dois furos de DMT, com a ferramenta do dilatômetro de Marchetti sendo cravada com o mesmo equipamento utilizado para a execução dos CPTs (Figura 3.12). A execução dos DMTs é caracterizada pela introdução no terreno de uma ferramenta de aço em forma de lâmina e a execução de um ensaio a cada trecho de 20 centímetros. Esta ferramenta é dotada de uma membrana circular expansível, que mede as forças necessárias para equilibrar a pressão do solo e para deslocar a membrana em 1,1 milímetros. 
Os resultados dos DMTs também mostraram a mesma tendência anterior com relação aos parâmetros mecânicos do estrato superficial, classificando o solo, tal como o CPT, como silte arenoso a argiloso. A Figura 3.15 mostra estes resultados.
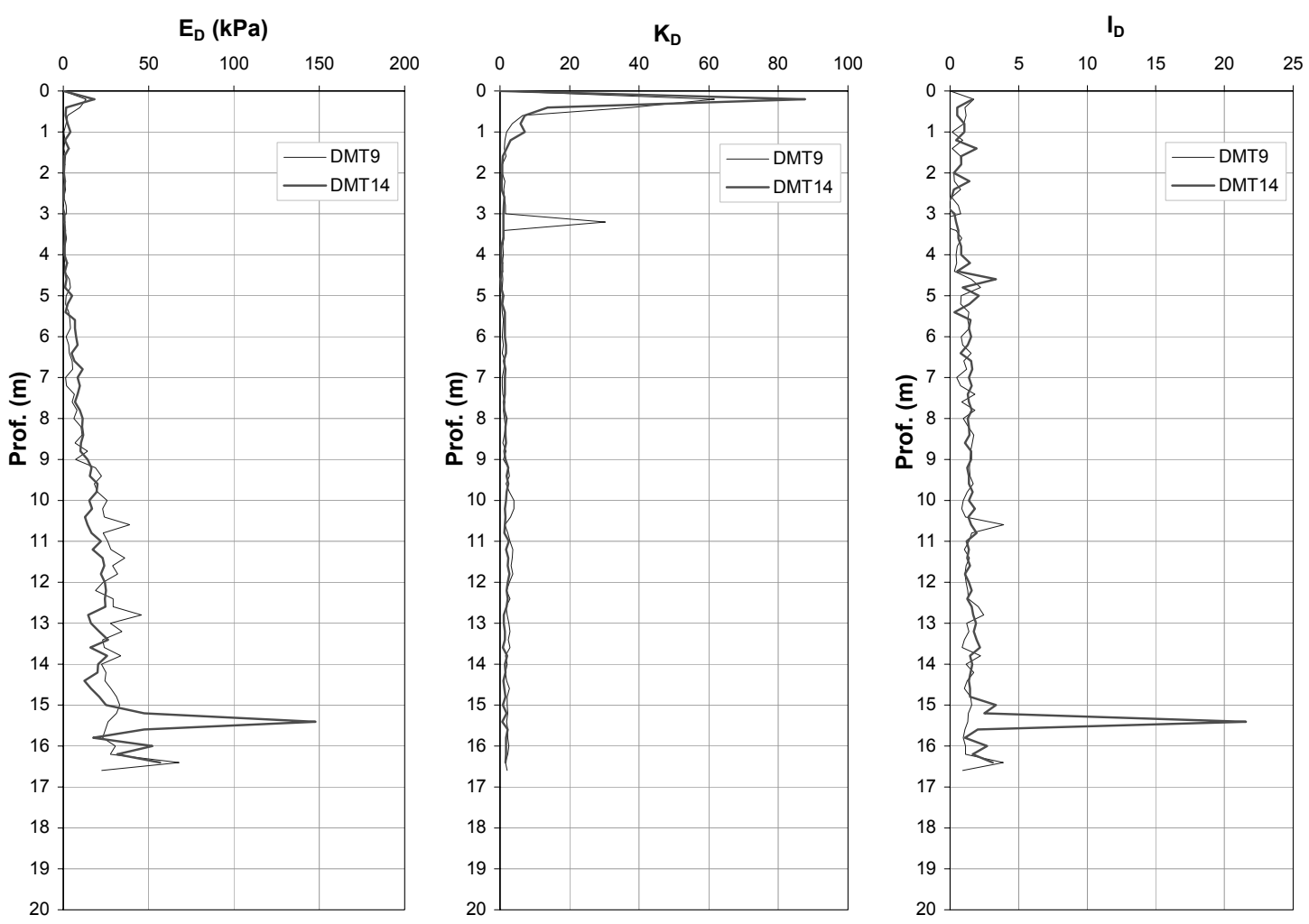

Figura 3.15 - Resultados dos DMTs

\section{(g) Permeabilidade in situ}

Foi feito, também, um ensaio de permeabilidade in situ, no primeiro metro, segundo as orientações para ensaios de permeabilidade de campo (ABGE, 1996), no dia 21 de setembro de 2004, cujo resultado está apresentado na Figura 3.16.

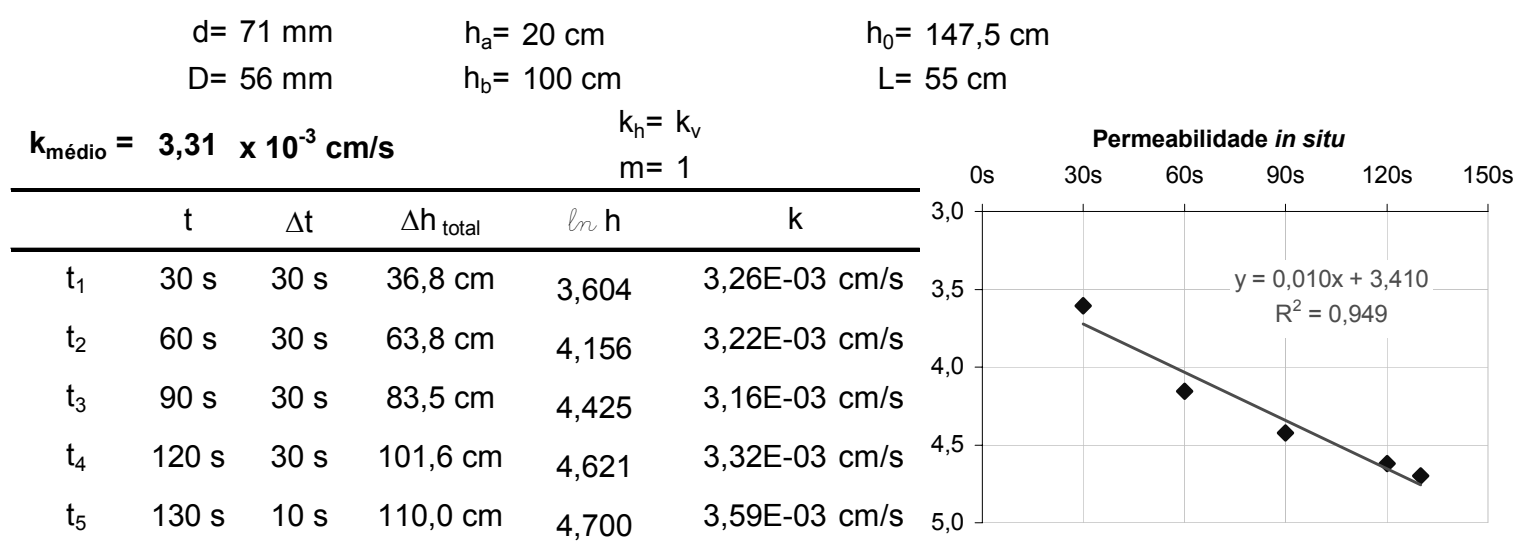

Figura 3.16 - Resultado do ensaio de permeabilidade in situ 
A permeabilidade encontrada é compatível com solos de granulometria maior que aquela determinada em laboratório de acordo com a NBR-7181 (1986), sendo mais compatível com a granulometria determinada sem o uso de defloculante.

\subsection{2- Ensaios de laboratório}

Os ensaios executados para a determinação das características principais em laboratório se constituíram em ensaios de caracterização (índices físicos, granulometria e plasticidade) e ensaios de propriedades de comportamento (compressibilidade e resistência ao cisalhamento). Ensaios específicos para a determinação das propriedades mecânicas do solo na região da ponta das estacas foram feitos posteriormente e estão detalhados nos capítulos 4- "Materiais e Métodos" e "5- Resultados: Apresentação e Análise".

\section{(c) Índices físicos}

A Tabela 3.3 mostra a média dos índices físicos por estratos, a partir das amostras coletadas nas sondagens.

Tabela 3.3 - Propriedades índices do solo do CEEG

\begin{tabular}{|l|c|c|c|}
\hline \multicolumn{1}{|c|}{ Valores médios } & $\begin{array}{c}\text { Estrato 1 } \\
\text { 0 a 12 m }\end{array}$ & $\begin{array}{c}\text { Estrato 2 } \\
\text { 12 a 16 m }\end{array}$ & $\begin{array}{c}\text { Estrato 3 } \\
\text { 16 a 21 m }\end{array}$ \\
\hline W (\%) & 33 & 39 & 48 \\
\hline LL (\%) & 61 & 67 & 74 \\
\hline LP (\%) & 45 & 50 & 53 \\
\hline IP (\%) & 16 & 17 & 21 \\
\hline Argila (\%) & 81 & 75 & 69 \\
\hline Silte (\%) & 12 & 14 & 17 \\
\hline Areia fina (\%) & 7 & 11 & 15 \\
\hline Massa específica dos sólidos $\left(\mathrm{kN} / \mathrm{m}^{3}\right)$ & 30,6 & 30,7 & 31,0 \\
\hline Consistência (SPT) & Mole a Média & Rija & Rija a Dura \\
\hline Massa específica do solo $\left(\mathrm{kN} / \mathrm{m}^{3}\right)$ & 14,0 & 16,0 & -- \\
\hline Índice de vazios & 2,0 & 1,42 & -- \\
\hline Porosidade (\%) & 66 & 59 & -- \\
\hline
\end{tabular}

Segundo Branco e Teixeira (2006), o primeiro estrato representa o horizonte B, resultado do intenso intemperismo sofrido pelo basalto. Apresenta elevado índice de vazios, baixa massa 
específica aparente e, provavelmente, elevada permeabilidade, condições características de solos marcados por processo de lixiviação. Esta estrutura macroporosa e microporosa é característica de solos lateríticos segundo a classificação MCT (Miniatura, Compacto, Tropical) Cozzolino e Nogami (1993).

Este estrato apresenta as principais condições para a ocorrência do fenômeno do colapso como, baixa massa específica natural, baixo teor de umidade e porosidade elevada. Este comportamento colapsível foi comprovado por Lopes (2002), por meio de ensaios edométricos, para certos níveis de tensão aplicada, até a profundidade de $5 \mathrm{~m}$.

A composição química e a estrutura do solo estudado foram avaliadas a partir de trabalhos publicados por Vargas (1951) e Rocha et al (1991). A mineralogia descrita por estes autores, admitida como representativa do perfil estudado, revela que a fração fina é caracterizada por argilominerais como a caulinita, a gibsita e a vermiculita, especialmente a caulinita. Foi encontrado, também, óxido de ferro sob a forma de hematita como importante constituinte desta fração.

A maioria dos ensaios de laboratório foi feita em amostras deste estrato e os resultados obtidos estão apresentados a seguir.

\section{(d) Granulometria}

Para a determinação das curvas granulométricas do primeiro estrato, foram coletadas amostras indeformadas de metro em metro, em um poço de inspeção, até $6 \mathrm{~m}$ de profundidade, sob as quais foram realizados ensaios em laboratório. Estes ensaios foram feitos segundo a norma brasileira NBR-7181 (1984) (com hexametafosfato de sódio) e, também, sem o uso de defloculante, visando identificar a granulometria aproximada do solo in situ. 
A Figura 3.17 mostra o gráfico com os resultados, onde pode ser observada a diferença significativa entre as curvas obtidas com e sem o uso do defloculante.

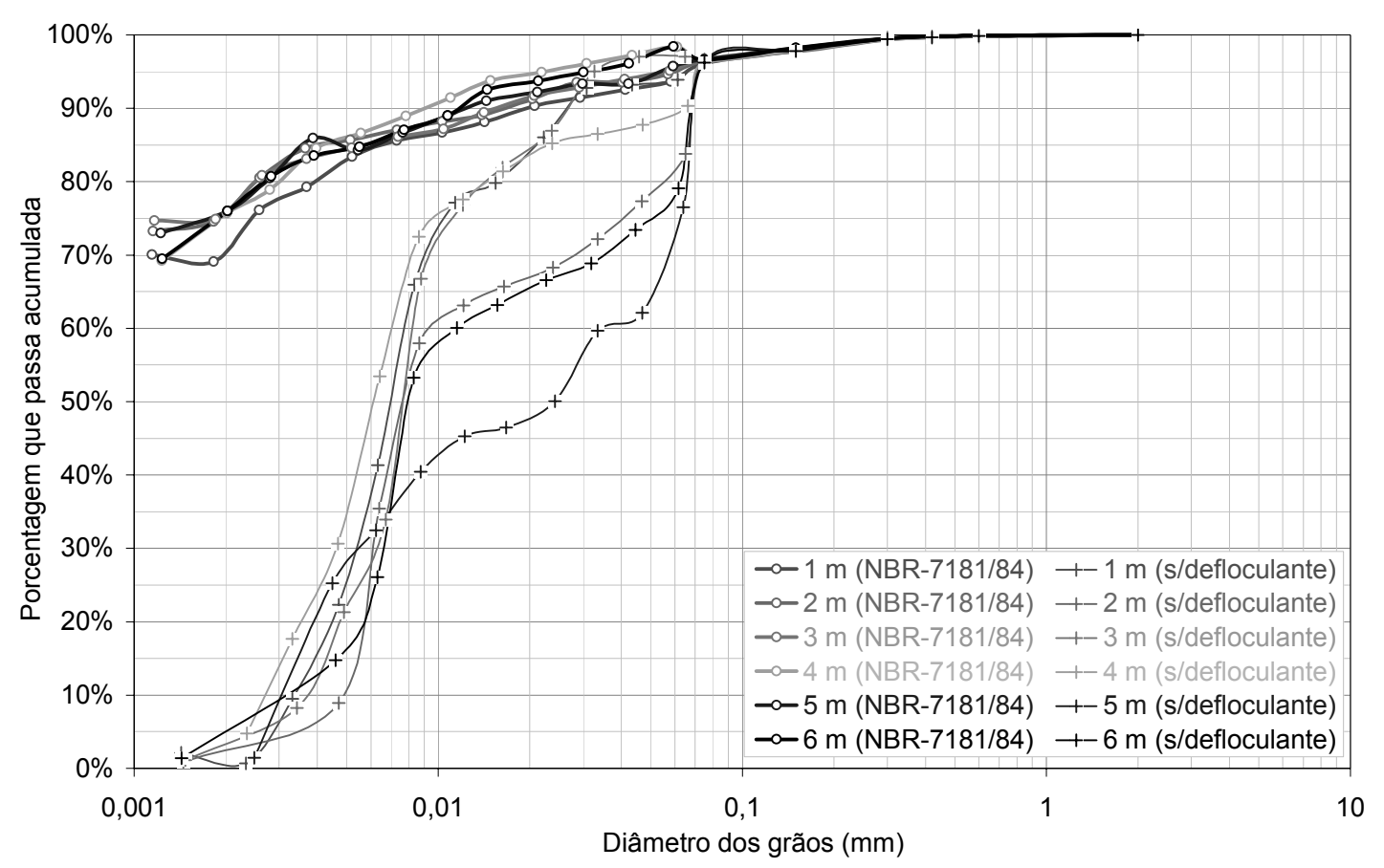

Figura 3.17 - Curvas granulométricas com e sem defloculante (amostras até $6 \mathrm{~m}$ ).

As determinações feitas usando-se o hexametafosfato de sódio resultaram em cerca de $85 \%$ de partículas de argila e $11 \%$ de silte. Para as determinações feitas sem defloculante, estes percentuais resultaram em cerca de $25 \%$ de argila e $60 \%$ de silte, o que mudaria, substancialmente, a classificação do primeiro estrato.

Assim, o solo que é classificado como uma argila siltosa, passaria a ser classificado como um silte argiloso. Estas características também foram encontradas por diversos pesquisadores, Arak (1997) e Peixoto et al (2001), convergindo para a ocorrência de microagregações de argila, com granulometria semelhante às de silte ou até mesmo de areia, quando em seu estado natural. 


\section{(e) Adensamento}

Foram realizados ensaios de adensamento, com e sem saturação, em amostras indeformadas das profundidades de 1 a 7 metros do primeiro estrato, classificado como argila porosa, vermelha, de consistência mole à média, segundo o SPT, colapsível e laterítica.

A Tabela 3.4 mostra as tensões de pré-adensamento e os coeficientes de adensamento obtidos, em confronto com as tensões geostáticas, mostrando que, nestas profundidades, o solo pode ser classificado como pré-adensado, pois todos os valores de OCR encontrados, até a profundidade de $6 \mathrm{~m}$, foram maiores que 1.

Tabela 3.4 - Parâmetros de adensamento

\begin{tabular}{|c|c|c|c|c|c|}
\hline \multirow{2}{*}{ Prof. } & \multirow{2}{*}{$\sigma_{\mathbf{v}}(\mathbf{k P a})$} & \multicolumn{2}{|c|}{ Amostra saturada } & \multicolumn{2}{c|}{ Amostra na w campo } \\
\cline { 3 - 6 } & & $\sigma_{\mathbf{a}}(\mathbf{k P a})$ & $\mathbf{C c}$ & $\sigma_{\mathbf{a}}(\mathbf{k P a})$ & $\mathbf{C c}$ \\
\hline $1 \mathrm{~m}$ & 14 & 46 & 0,66 & 61 & 0,68 \\
\hline $2 \mathrm{~m}$ & 27 & 51 & 0,66 & 75 & 0,70 \\
\hline $3 \mathrm{~m}$ & 41 & 78 & 0,56 & 80 & 0,20 \\
\hline $4 \mathrm{~m}$ & 55 & 75 & 0,53 & 92 & 0,23 \\
\hline $5 \mathrm{~m}$ & 69 & 90 & 0,56 & 110 & 0,48 \\
\hline $6 \mathrm{~m}$ & 99 & 130 & 0,50 & 120 & 0,54 \\
\hline $7 \mathrm{~m}$ & 105 & 150 & 0,37 & 210 & 0,40 \\
\hline
\end{tabular}

\section{(f) Colapso}

Foi feita a avaliação da colapsibilidade do solo deste horizonte através de ensaios edométricos em corpos de prova ensaiados nas condições sem e com inundação, para vários níveis de carregamento. A análise dos resultados indicou que o solo apresenta comportamento colapsível para certos níveis de tensão, que o índice de subsidência varia para a mesma profundidade em função do nível de tensão em que é feita a inundação e que existe uma estreita relação entre o teor de umidade e o colapso.

A Figura 3.18 mostra os valores de $\mathrm{R}_{\mathrm{w}}$ (índice de subsidência) com a tensão do estágio de carregamento no qual houve a inundação do corpo de prova, para as profundidades 
investigadas. Índices de subsidência superiores a $2 \%$ classificam o solo como colapsível, para aqueles níveis de tensão (VARGAS, 1993).

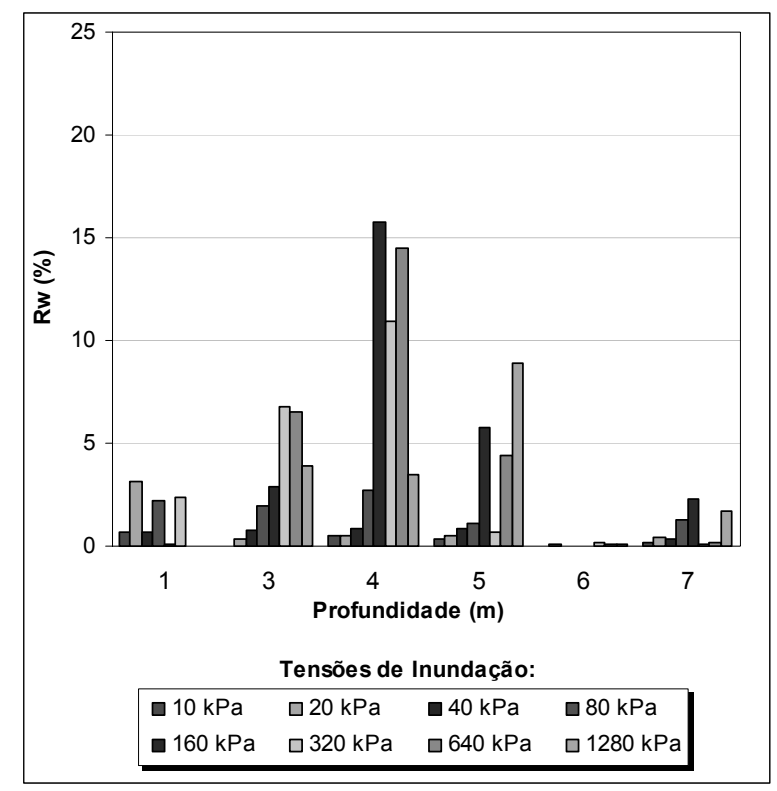

Figura 3.18 - Índice de subsidência do estrato superficial

Sob tensões baixas, o solo não apresentou comportamento colapsível $\left(\mathrm{R}_{\mathrm{w}}<2 \%\right)$. Para a mesma profundidade, os valores de $\mathrm{R}_{\mathrm{w}}$ apresentaram-se crescentes com o aumento da tensão aplicada, atingindo um valor máximo e tornando-se decrescente a partir deste ponto, principalmente para as profundidades de 3 e $4 \mathrm{~m}$. Este comportamento já foi descrito por muitos autores e deve-se ao fato de que a inundação sob baixas tensões não é suficiente para sensibilizar a estrutura do solo, mas à medida em que a inundação é feita sob tensões maiores, ocorre a redução brusca de volume do solo caracterizando o colapso do solo. No entanto, sob tensões tidas como elevadas, observa-se que esta redução de volume torna-se menor, pois a magnitude da tensão é suficiente para impor ao solo um nível de deformação, tornando-o pouco sensível à inundação. Este comportamento colapsível não se constata para o primeiro metro de profundidade, possivelmente devido ao fato de ser um estrato mais suscetível a perturbações ambientais. 
Os resultados dos ensaios realizados em corpos de prova provenientes da profundidade de $2 \mathrm{~m}$ apontam no sentido da grande influência do teor de umidade inicial no comportamento colapsível do solo. Para os corpos de prova inundados no estágio de tensão final de $1280 \mathrm{kPa}$, verificou-se que, quando estes foram secos por 24 horas, com uma queda de nove pontos percentuais no teor de umidade, o índice de subsidência passou a ser de aproximadamente $23 \%$, contra um índice de subsidência de $0,6 \%$ dos corpos de prova inundados no mesmo estágio de pressão, mas ensaiados na umidade de moldagem de 35\%.

\section{(g) Curva característica de sucção}

As curvas características de sucção foram determinadas através do Aparelho de Richards (câmara de sucção) em amostras indeformadas provenientes das profundidades de 4 e 6 m, conforme ilustrado nas Figuras 3.19 e 3.20 .

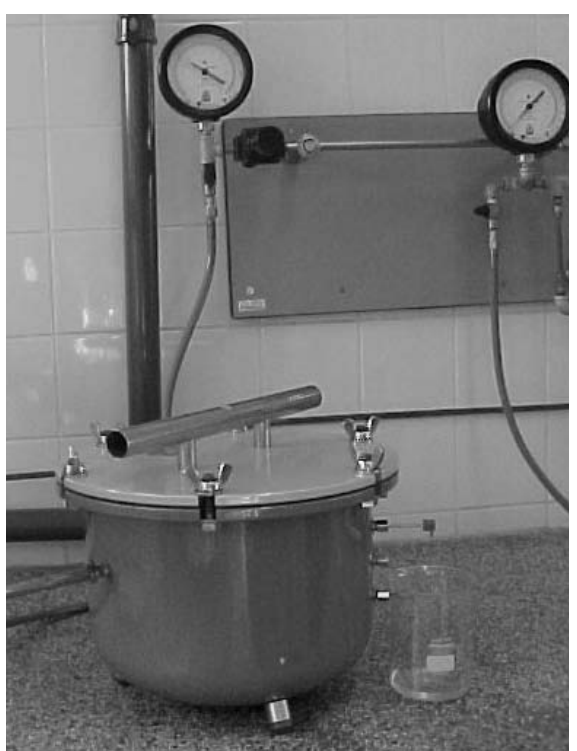

Figura 3.19 - Aparelho de Richards

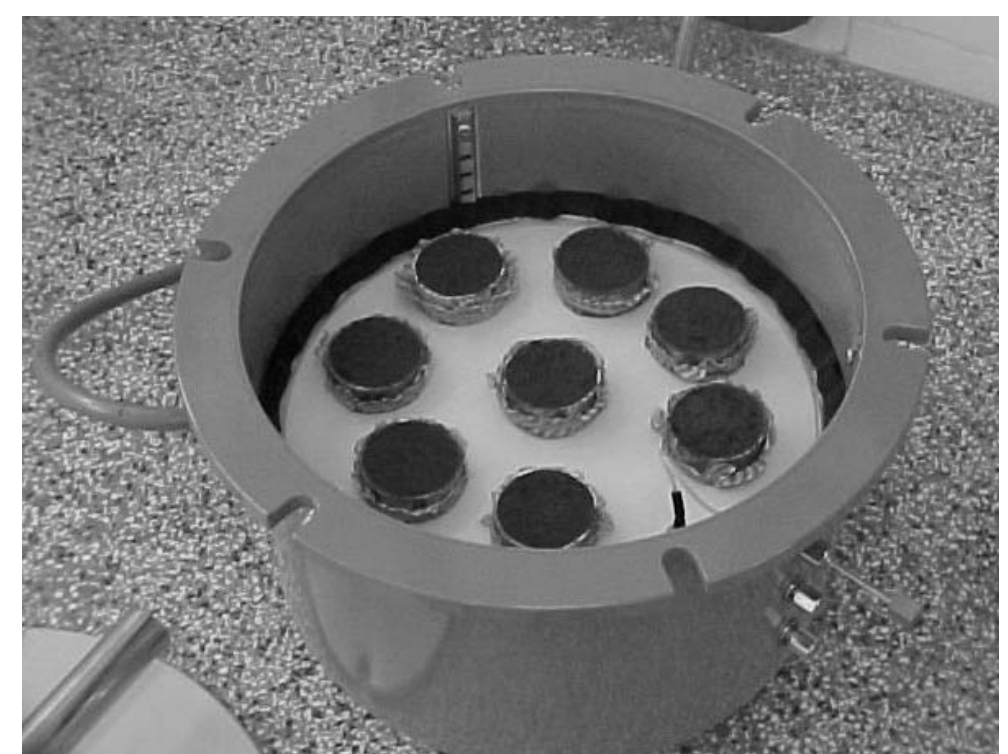

Figura 3.20 - Detalhe das amostras de solo sobre a pedra porosa

O formato das curvas obtidas (Figura 3.21) se apresentou como típico de solos granulares, com distribuição mal graduada dos poros, confirmando o comportamento granular do solo da região que, apesar de possuir textura de solo fino, apresenta estrutura agregada, típica de solos tropicais. As curvas de sucção transformadas em relação aos índices de vazios (Figura 3.22) também são apresentadas e, apesar da semelhança no traçado das curvas para as 
profundidades investigadas, ficou evidenciada a mudança de estrutura do solo ao longo do perfil.

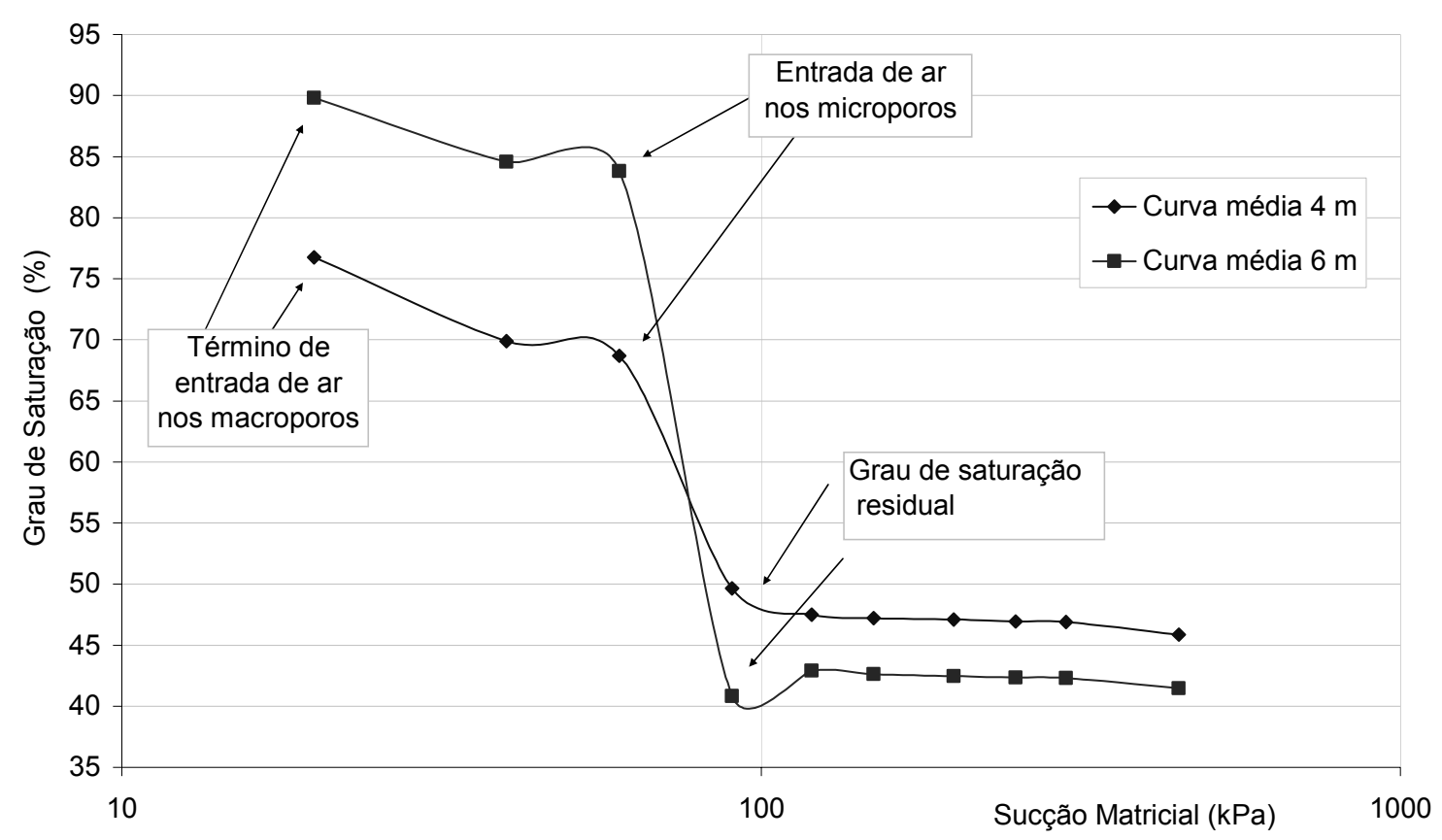

Figura 3.21 - Curvas características de sucção médias (profundidades de $4 \mathrm{~m} \mathrm{e} 6 \mathrm{~m}$ ).

As curvas características de sucção obtidas são típicas de solos nos quais a distribuição dos poros é bimodal, ou seja, mal graduada ou de granulação aberta e se assemelham à curvas obtidas para outros solos lateríticos. Além disso, os formatos dessas curvas são de solos arenosos e não de solos finos. Esse fato contribui para reforçar o comportamento granular do solo estudado, em função da estrutura agregada.

Observou-se uma variabilidade nas curvas características de amostras retiradas de mesma profundidade, explicada pelo fato de que, apesar dessas amostras terem sido retiradas do mesmo bloco de solo indeformado, elas apresentaram diferenciações na sua estrutura, fato constatado nos valores distintos de teor de umidade e de índices de vazios. 


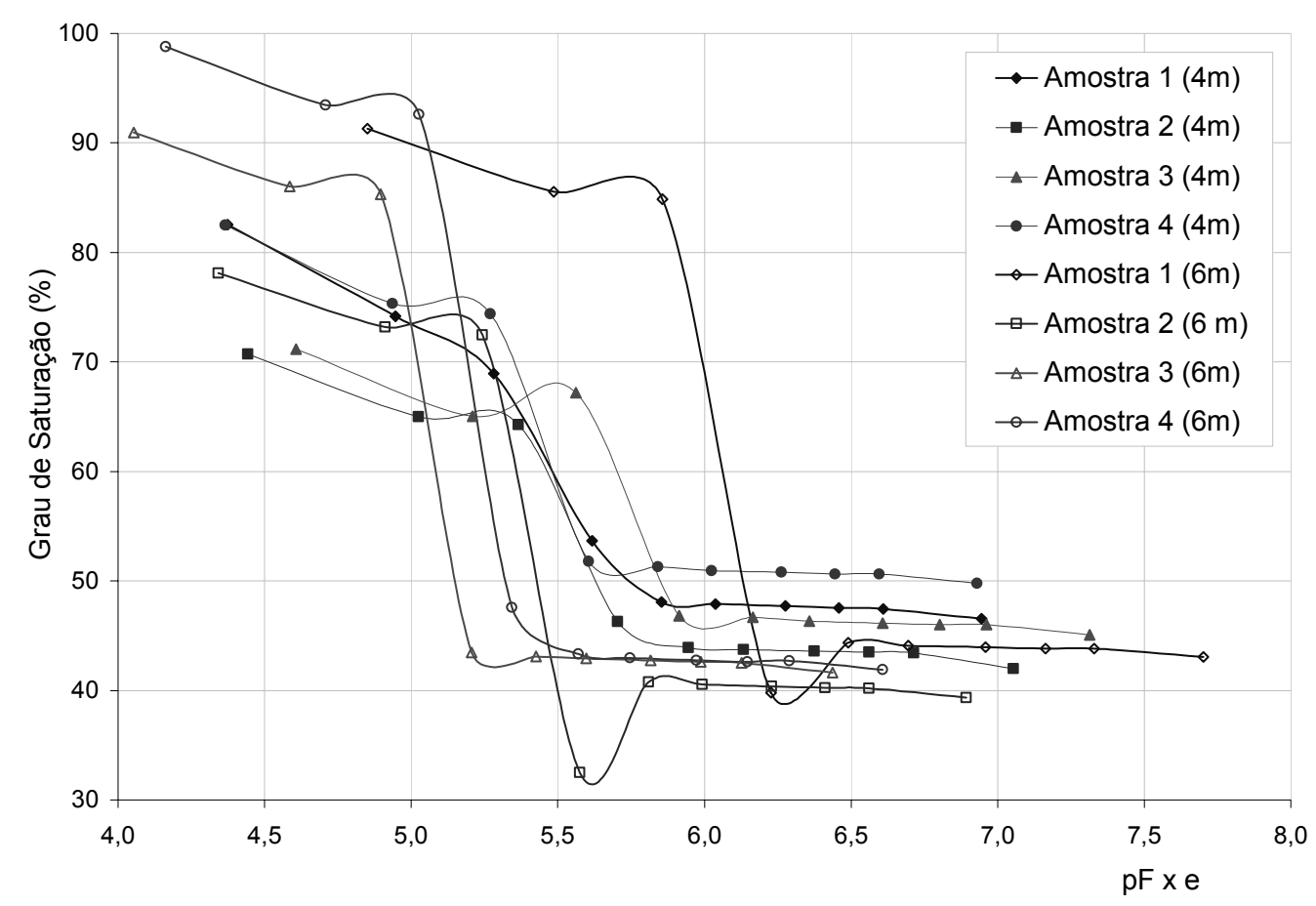

Figura 3.22 - Curvas características de sucção transformadas (profundidades de $4 \mathrm{~m} \mathrm{e} 6 \mathrm{~m}$ ).

As curvas características para ambas as profundidades estudadas têm a tendência de um traçado semelhante. Mas para sucções menores que $90 \mathrm{kPa}$ (grau de saturação residual), a curva referente à profundidade de $4 \mathrm{~m}$ aponta valores de teor de umidade menores, para um mesmo valor de sucção, que a curva referente à profundidade de $6 \mathrm{~m}$. Para sucções maiores que $90 \mathrm{kPa}$, a curva referente a $4 \mathrm{~m}$ de profundidade mostra valores de teor de umidade maiores que os da curva referente a $6 \mathrm{~m}$ e praticamente constante com o aumento da sucção.

Das curvas de sucção transformadas observou-se que as curvas de mesma profundidade, porém com índices de vazios maiores, apresentam valores de sucção menores e vice-versa. Pode-se também observar a influência da mudança de estrutura do solo ao longo do perfil, que é a responsável por curvas distintas.

De acordo com os cálculos, a ocorrência do colapso se deu sob teores de umidade próximos de $33 \%$, que representam um valor aproximado de sucção matricial de $90 \mathrm{kPa}$. Para valores de umidade menores, há uma variação muito pequena dos valores de sucção, estando esses no trecho de grau de saturação residual. 


\section{(h) Resistência ao cisalhamento}

Foram realizados ensaios triaxiais do tipo CU em amostras indeformadas retiradas das profundidades de $3 \mathrm{~m}, 6 \mathrm{~m}$ e $9 \mathrm{~m}$, com tensões confinantes de 50, 200 e $400 \mathrm{kPa}$. Estas amostras foram retiradas em uma área próxima ao CEEG (distância de 128,65 m a sudeste da origem do CEEG, nas coordenadas UTM X=487945,7 e Y=7410597,3). Dos resultados dos índices físicos destas amostras pode-se considerar que pertencem à mesma formação e apresentam as mesmas características físicas e morfológicas do solo do CEEG. Portanto, os parâmetros de resistência ao cisalhamento dessas amostras podem ser representativos do CEEG. As tensões confinantes de 200 e $400 \mathrm{kPa}$, usadas nos ensaios, ultrapassaram as tensões de pré-adensamento das amostras e, por isso, o intercepto de coesão foi tomado como zero. A Tabela 3.5 mostra os ângulos de atrito total para as 3 profundidades ensaiadas.

Tabela 3.5 - Ângulo de atrito do solo (ensaios CU)

\begin{tabular}{|c|c|}
\hline Profundidade & Ângulo de atrito total \\
\hline $3 \mathrm{~m}$ & $26,5^{\circ}$ \\
\hline $6 \mathrm{~m}$ & $25,0^{\circ}$ \\
\hline $9 \mathrm{~m}$ & $29,0^{\circ}$ \\
\hline
\end{tabular}




\section{4- MATERIAIS E MÉTODOS}

O método empregado na pesquisa foi baseado na verificação do comportamento de 16 de um total de 25 estacas escavadas de pequeno diâmetro, através de provas de carga dinâmicas (PCD) e algumas estáticas (PCE), para calibração. A opção por provas de carga dinâmicas foi tomada com os objetivos de verificar a distribuição de carga entre o fuste e a ponta das estacas e de restringir as variáveis dependentes, diminuindo a variabilidade relativa à variação da sucção.

As estacas foram escavadas a seco com trado mecânico, com diâmetro nominal de $25 \mathrm{~cm}$ e comprimento de $12 \mathrm{~m}$, utilizando-se os procedimentos e equipamentos rotineiros para este tipo de fundação. A perfuratriz utilizada é dotada de um trado contínuo de $6 \mathrm{~m}$, com uma haste interna de prolongamento, de mais $6 \mathrm{~m}$ (Figuras 4.1 e 4.2). O acionamento do trado é feito através de um motor elétrico acoplado a um redutor mecânico para manter o torque elevado, com baixa rotação. Antes da concretagem, 13 das 16 estacas ensaiadas tiveram a ponta preparada de formas distintas, para confrontar seus comportamentos com o daquelas concretadas sem preparo algum.

Foi verificado, também, o efeito da inundação no comportamento das estacas. A definição de inundação aqui utilizada não corresponde à inundação total da estaca, mas à manutenção da inundação de uma cava na superfície em torno da estaca, por 48 horas antes e, também, 
durante os ensaios. A intenção foi a de reproduzir condições tão severas quanto aquelas que poderiam ocorrer em uma obra, no caso de uma eventual inundação superficial.

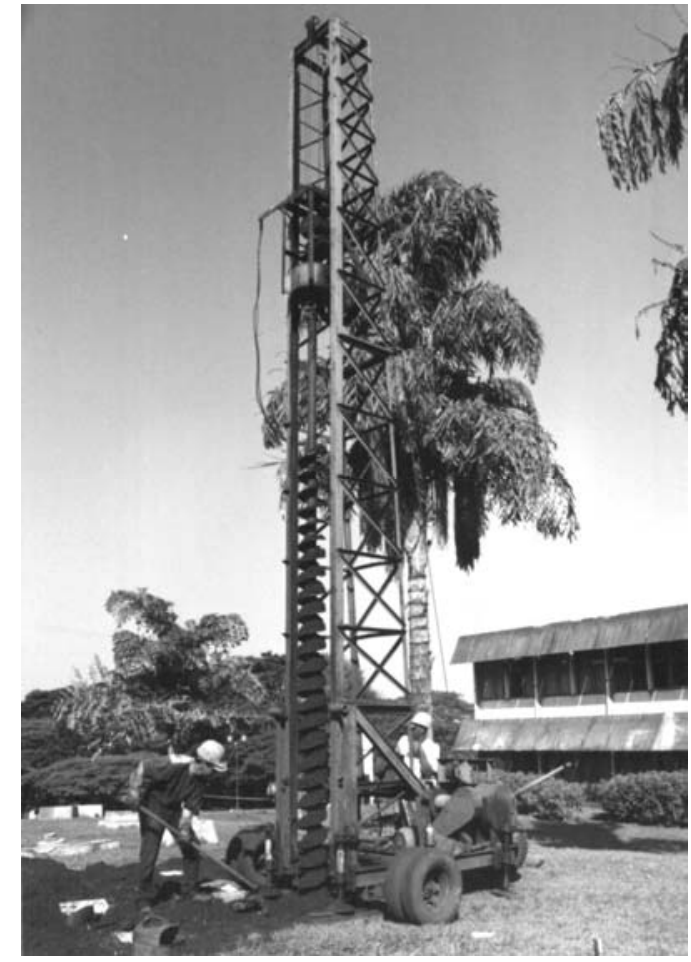

Figura 4.1 - Vista geral da perfuratriz

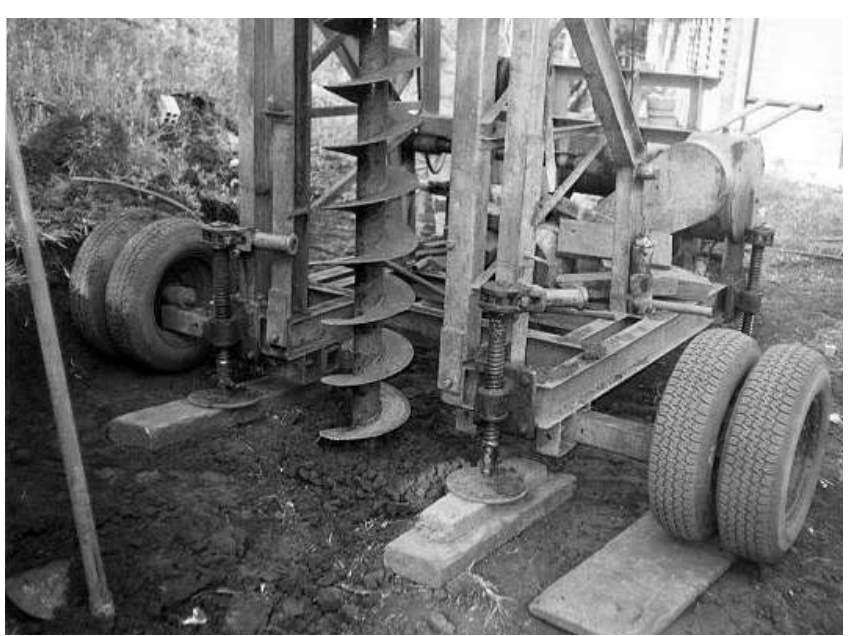

Figura 4.2 - Detalhe da perfuratriz e do trado

A seqüência empregada na descrição dos itens deste capítulo foi a dos métodos executivos e de cada uma das fases da pesquisa, em ordem cronológica.

\section{1- Execução das estacas}

Foram executadas 25 estacas com diâmetro nominal de $0,25 \mathrm{~m}$, comprimento de $12 \mathrm{~m}$ e espaçamento entre eixos de $1,5 \mathrm{~m}$, sendo:

(a) Seis estacas executadas da forma tradicional e identificadas pela palavra "original" e pela sigla $(\mathrm{O})$;

(b) Seis estacas executadas com discos de isopor na ponta e identificadas pela palavra “isopor” e pela sigla (I); 
(c) Nove estacas executadas com ponta modificada, sendo três estacas com cada tipo de modificação e identificadas, respectivamente, pelas palavras "limpa com caçamba", "solo melhorado", "bucha de Strauss" e pelas siglas (LC), (SM) e (BS);

(d) Quatro estacas executadas com o uso de um equipamento especialmente desenvolvido e identificadas pela palavra "base alargada" e pela sigla (BA).

As estacas com ponta de isopor foram concretadas após a introdução de seis discos de isopor (Styropor, da BASF Plastics, com densidade de $20 \mathrm{~kg} / \mathrm{m}^{3}$ ), com diâmetro de 0,25 m e espessura de 0,05 m, no fundo da escavação. Estes discos foram solidarizados a um disco de madeira no topo, onde foi parafusado um gancho com a finalidade de guiar os discos até o fundo da escavação (Figuras 4.3 e 4.4).

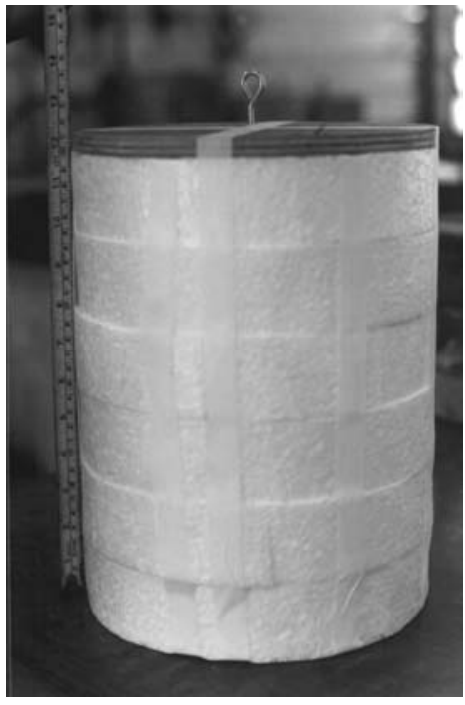

Figura 4.3 - Discos de isopor

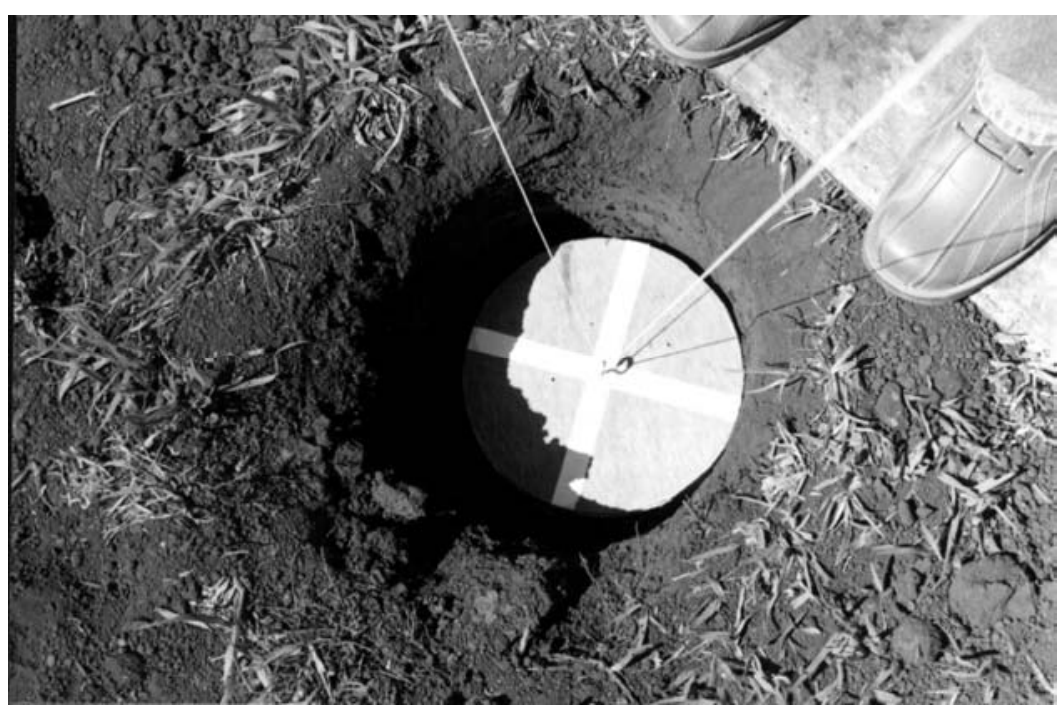

Figura 4.4 - Descida dos discos

Para a concretagem das estacas foi utilizado concreto usinado com cimento de alta resistência inicial (ARI), $f_{c k}=15 \mathrm{MPa}$ e slump $=8 \pm 1 \mathrm{~cm}$, obedecendo as mesmas características do concreto empregado rotineiramente neste tipo de estaca.

Para permitir a execução das provas de carga dinâmicas (PCDs), o topo das estacas foi "cintado" com um tubo de aço com parede de $3 \mathrm{~mm}$, diâmetro igual ao da estaca e 
comprimento de $30 \mathrm{~cm}$ e utilizada uma forma constituída por um tubo de PVC com diâmetro de $25 \mathrm{~cm}$ e comprimento de $30 \mathrm{~cm}$. Nas estacas da área 4 o tubo de PVC foi fixado ao tubo de aço com tiras adesivas e nas estacas da área 5 o tubo de PVC foi parafusado no tubo de aço para facilitar o alinhamento das peças (Figura 4.5). Para a instalação da instrumentação do PDA os tubos de PVC foram removidos, expondo totalmente a superfície regular das estacas.

Foi utilizada, também, uma armadura mínima para resistir aos esforços de tração provocados pelas ondas de choque. Esta armadura consistiu de quatro barras longitudinais, com diâmetro de $8 \mathrm{~mm}$ e estribos quadrados, com barras de aço com diâmetro de 4,2 mm, espaçados de 15 centímetros.

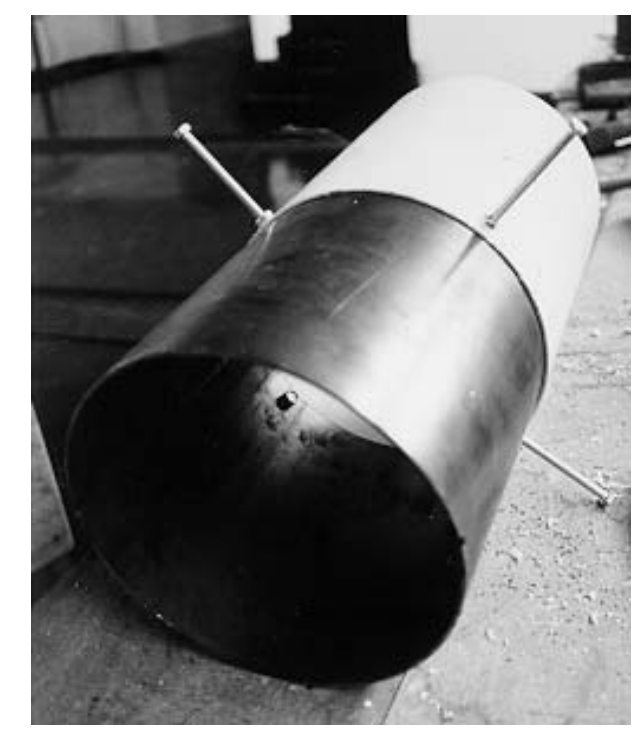

Figura 4.5 - Tubo de aço de cintamento e forma de PVC

As armaduras foram descidas nas escavações com o auxílio de um guindaste com uma lança de $15 \mathrm{~m}$, para minimizar ao máximo a queda posterior de detritos (Figura 4.6). 


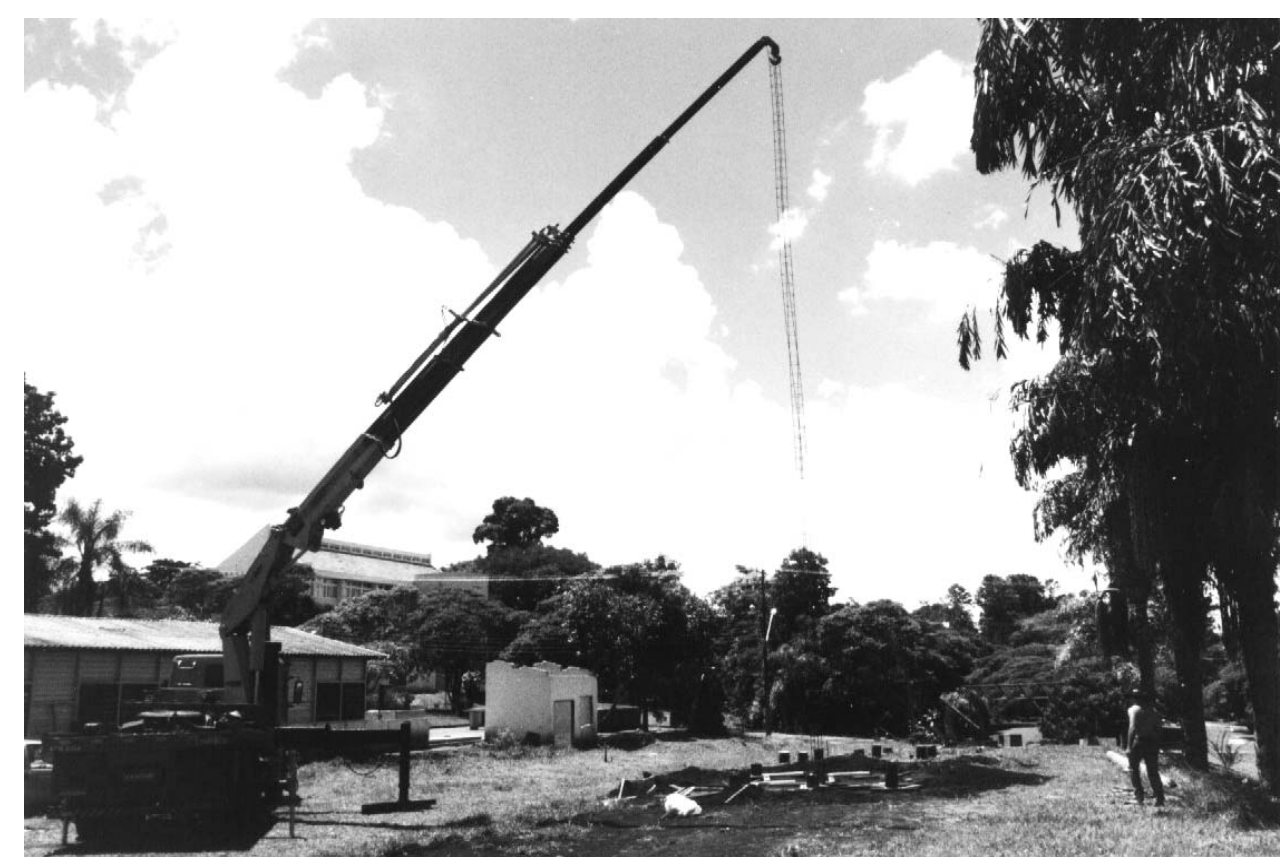

Figura 4.6 - Armadura sendo posicionada

\section{2- Execução das provas de carga dinâmicas (PCDs)}

Todas as 16 estacas pesquisadas foram ensaiadas e reensaiadas imediatamente após os ensaios, através de PCDs, utilizando-se um equipamento da Pile Dynamic Inc. (PDI), composto por um analisador de cravação de estacas (PDA) e um conjunto de sensores formado por um par de strain gauges e um par de acelerômetros.

Este equipamento tem as seguintes características:

- analisador de cravação de estacas PDA, modelo portátil

- strain gauges com sensibilidade entre 350 e $450 \mu \mathrm{s} / \mathrm{mV} / \mathrm{V}$

- acelerômetros piezelétricos com amplificador acoplado, com sensibilidade de $1 \mathrm{mV} / \mathrm{g}$

Para prover o esforço de cravação necessário para a realização dos ensaios foi utilizado um bate-estacas, modelo F-10, dotado de um guincho elétrico, com embreagem. Projetado e construído especificamente para estes ensaios, dispõe de um martelo de queda livre, com massa de $930 \mathrm{~kg}$ e altura de queda máxima de 2,20 m (Figuras 4.7 e 4.8). 


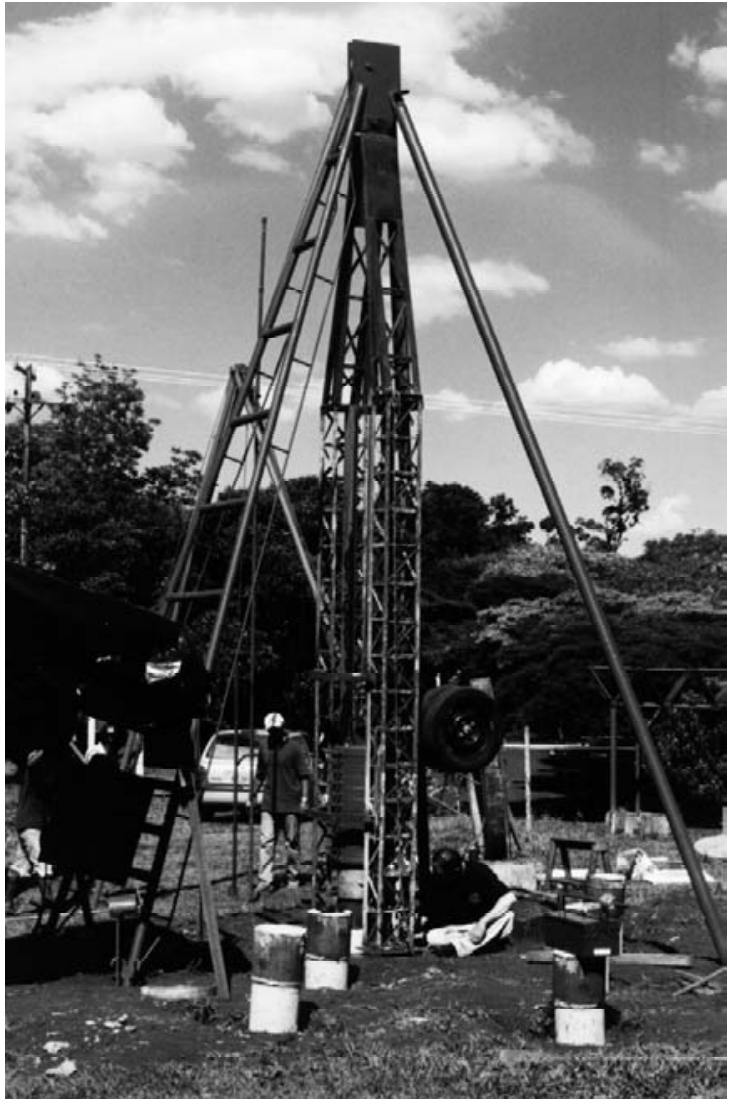

Figura 4.7 - Vista geral do bate-estacas (VESSARO et al., 2004)

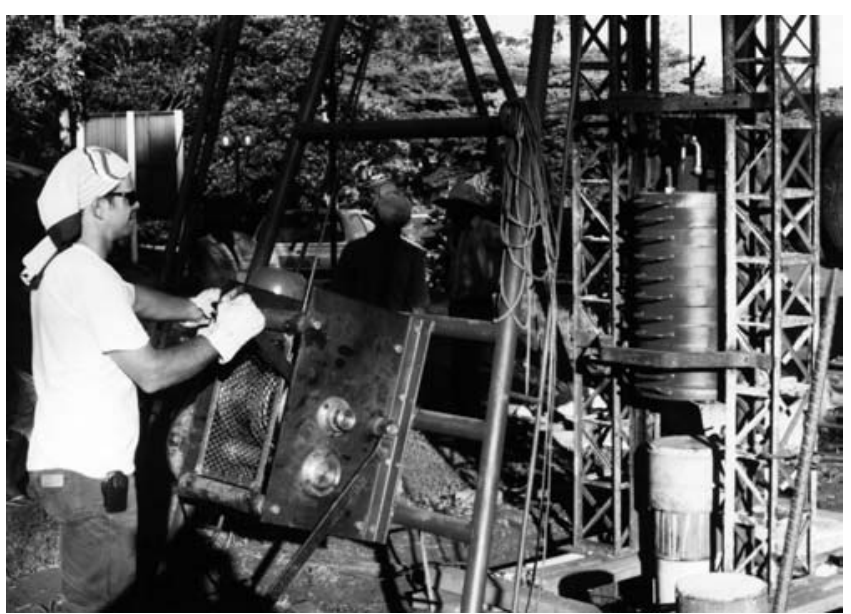

Figura 4.8 - Detalhe do equipamento (VESSARO et al., 2004)

O capacete é constituído por um anel metálico com guias, tem uma massa de $50 \mathrm{~kg}$ e é provido de um cepo de madeira dura (peroba), de cerca de $150 \mathrm{~mm}$ de espessura na parte superior e um coxim formado por discos de madeira mole (pinus), com cerca de 30 a $40 \mathrm{~mm}$ de espessura total na parte inferior (Figura 4.9).

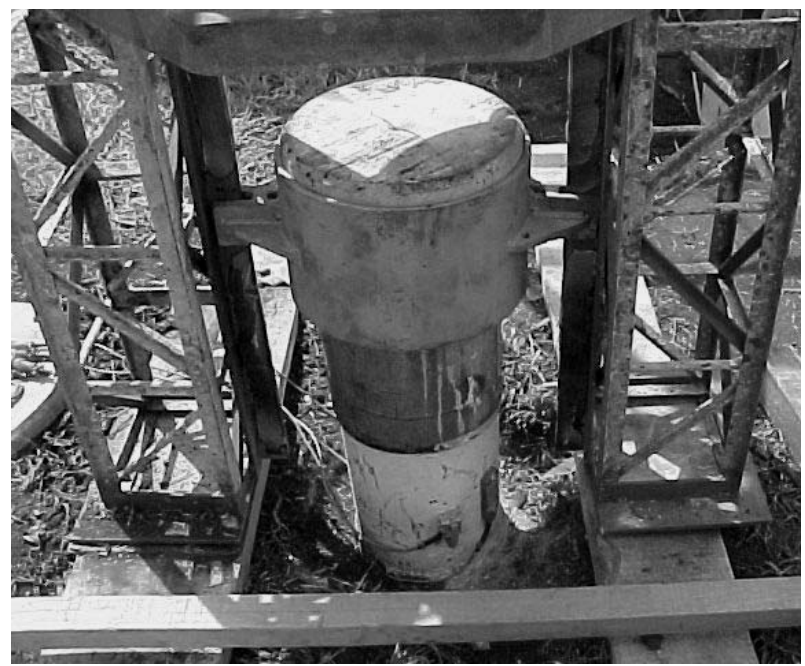

Figura 4.9 - Capacete e estaca instrumentada (VESSARO et al., 2004) 
As PCDs foram executadas com energia crescente (DIET, de Dynamic Increasing Energy Test, na denominação de AOKI, 1997), com alturas de queda variando entre 0,40 a 1,60 m. Todas as estacas foram ensaiadas e reensaiadas em média, com 6 golpes. Foram tomadas as medidas de repique e nega, da forma tradicional, com papel, régua e lápis (Figura 4.10).

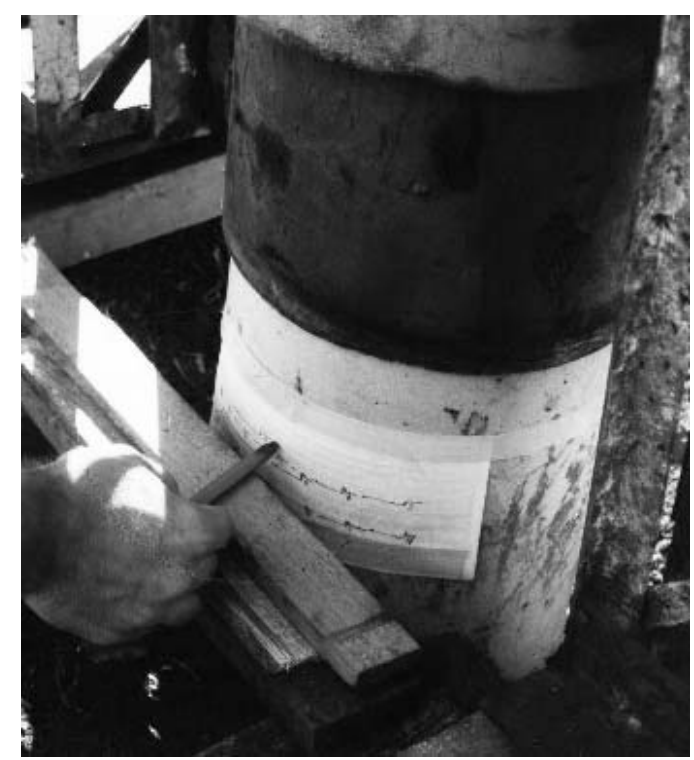

Figura 4.10 - Medidas de nega e repique (VESSARO et al., 2004)

No caso das PCDs com pré-inundação, foram escavadas cavas de cerca de 40 x 40 x $20 \mathrm{~cm}$ ao redor das estacas, com a manutenção da inundação por 48 horas antes e durante os ensaios.

\section{3- Execução das provas de carga estáticas (PCEs)}

Foram executadas seis PCEs, sendo duas na estaca $A 1(O)$ e quatro na estaca $A 4(O)$, visando verificar os seus comportamentos sob condições normais (sem pré-inundação), com préinundação e em reensaios. Para a execução das PCEs foi necessária a execução de quatro estacas adicionais de reação. Estas estacas também foram escavadas a seco com o trado mecânico, com as seguintes especificações:

- Diâmetro de $0,25 \mathrm{~m}$ e comprimento de $12 \mathrm{~m}$

- Armadura longitudinal composta por três barras de $16 \mathrm{~mm}$ de diâmetro e comprimento de $12 \mathrm{~m}$, soldadas a uma barra Dywidag St 85/105, diâmetro de $32 \mathrm{~mm}$ 
e comprimento de $1 \mathrm{~m}$

- Concreto com cimento ARI, com $f c k=15 \mathrm{MPa}$ e slump $=8 \pm 1 \mathrm{~cm}$

Para a execução das PCEs foi utilizado o arranjo clássico de uma viga ancorada em duas estacas de reação. A viga tinha $4 \mathrm{~m}$ de comprimento e foi adaptada para estas PCEs, através do acréscimo de duas vigas transversais unidas por tirantes de aço (Figura 4.11). A aplicação das cargas foi feita através de um macaco hidráulico monitorado por uma célula de carga ligada a um indicador de deformações.

As especificações dos equipamentos utilizados são as seguintes:

- Viga de reação de aço, com capacidade para $500 \mathrm{kN}$, ancorada em duas reações

- Macaco hidráulico com capacidade para $2000 \mathrm{kN}$

- Célula de carga com capacidade para $500 \mathrm{kN}$

- Rótula para ajustes entre os componentes

- Indicador de deformações analógico

- Relógios comparadores com curso de $50 \mathrm{~mm}$ e resolução $0,01 \mathrm{~mm}$ (estacas em ensaio)

- Relógios comparadores com curso de $30 \mathrm{~mm}$ e resolução $0,01 \mathrm{~mm}$ (reações) 


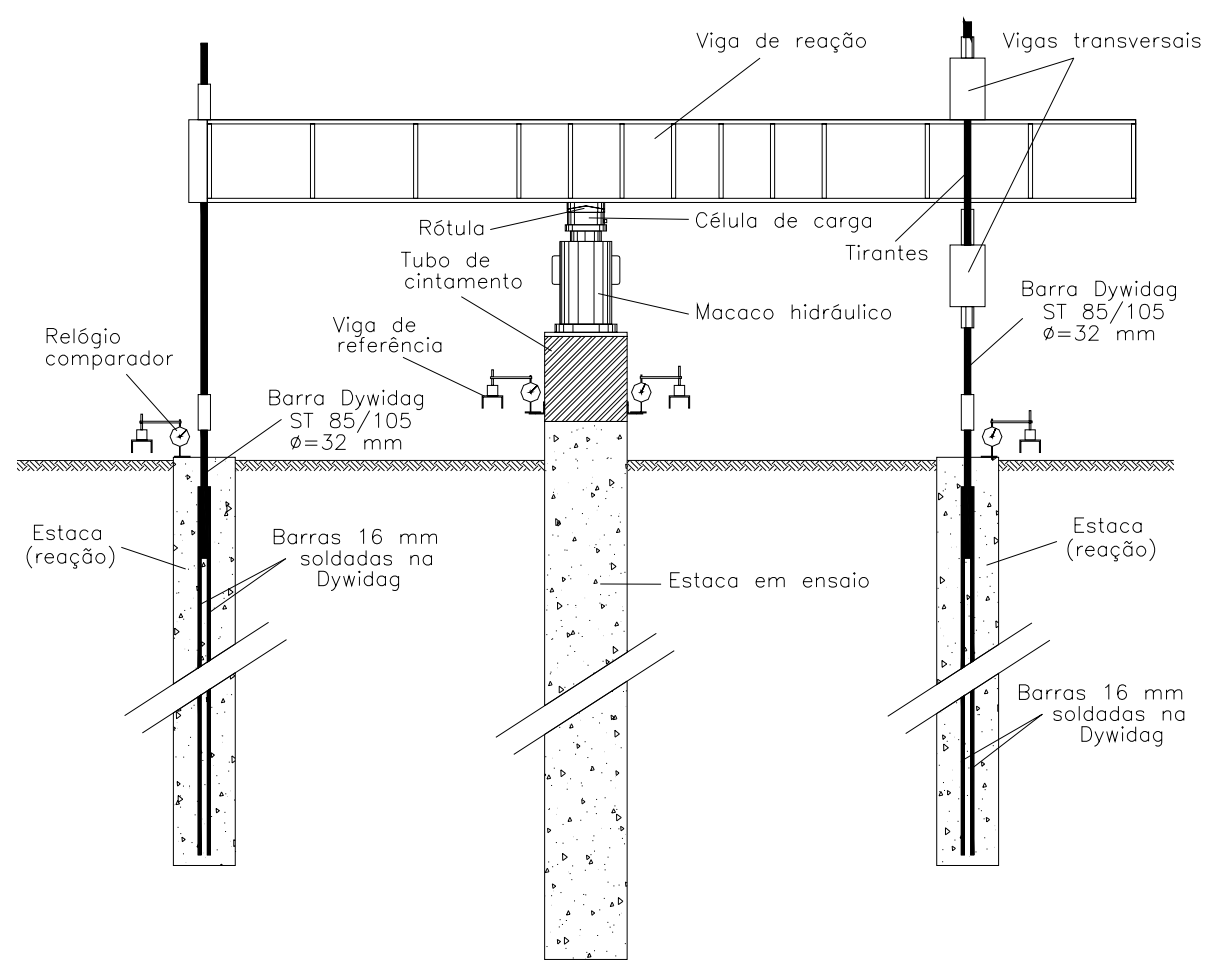

Figura 4.11 - Arranjo geral das PCEs (sem escala)

As PCEs foram do tipo de carregamento rápido (QML), com incrementos de carga aplicados de $15 \mathrm{kN}$, mantidos por 5 minutos, independente da estabilização do recalque, conforme procedimentos preconizados pela MB-3472 (1991), da ABNT.

Para a execução das PCEs com pré-inundação foram escavadas, ao redor das estacas A1(O) e A4(O), cavas de cerca de 40 x 40 × $20 \mathrm{~cm}$, que foram mantidas sob inundação por 48 horas antes e durante os ensaios.

\section{4- Etapas da pesquisa}

A pesquisa foi dividida em seis etapas e, para evitar vícios de escolha, a disposição dos vários tipos de estacas em cada etapa foi escolhida por sorteio, conforme Figuras 4.12 a 4.15. 


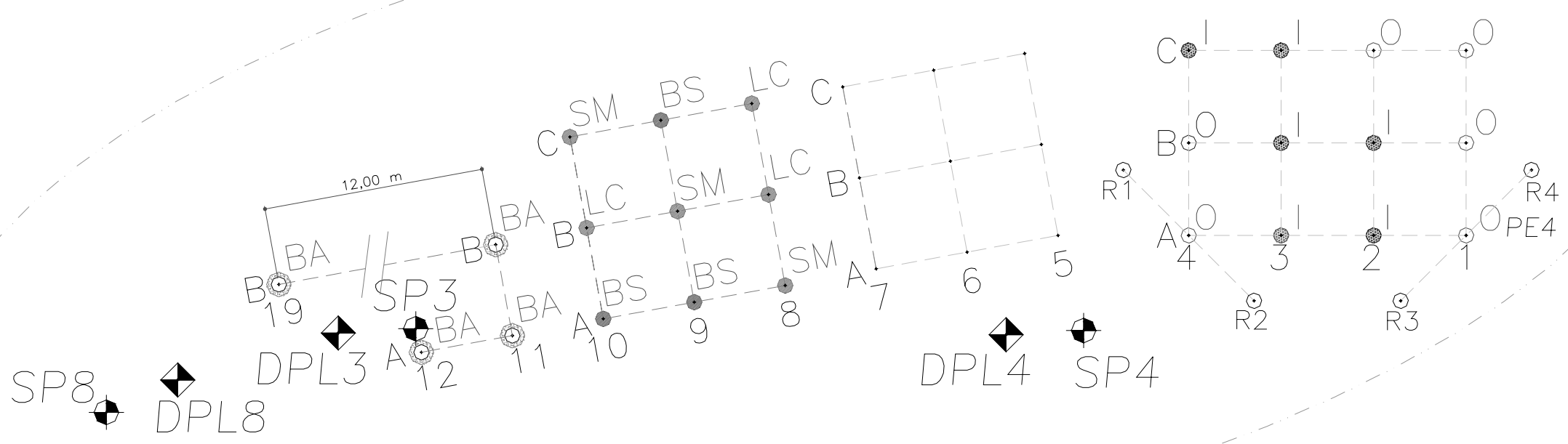

Figura 4.12 - Detalhe das áreas de pesquisa 4 e 5 


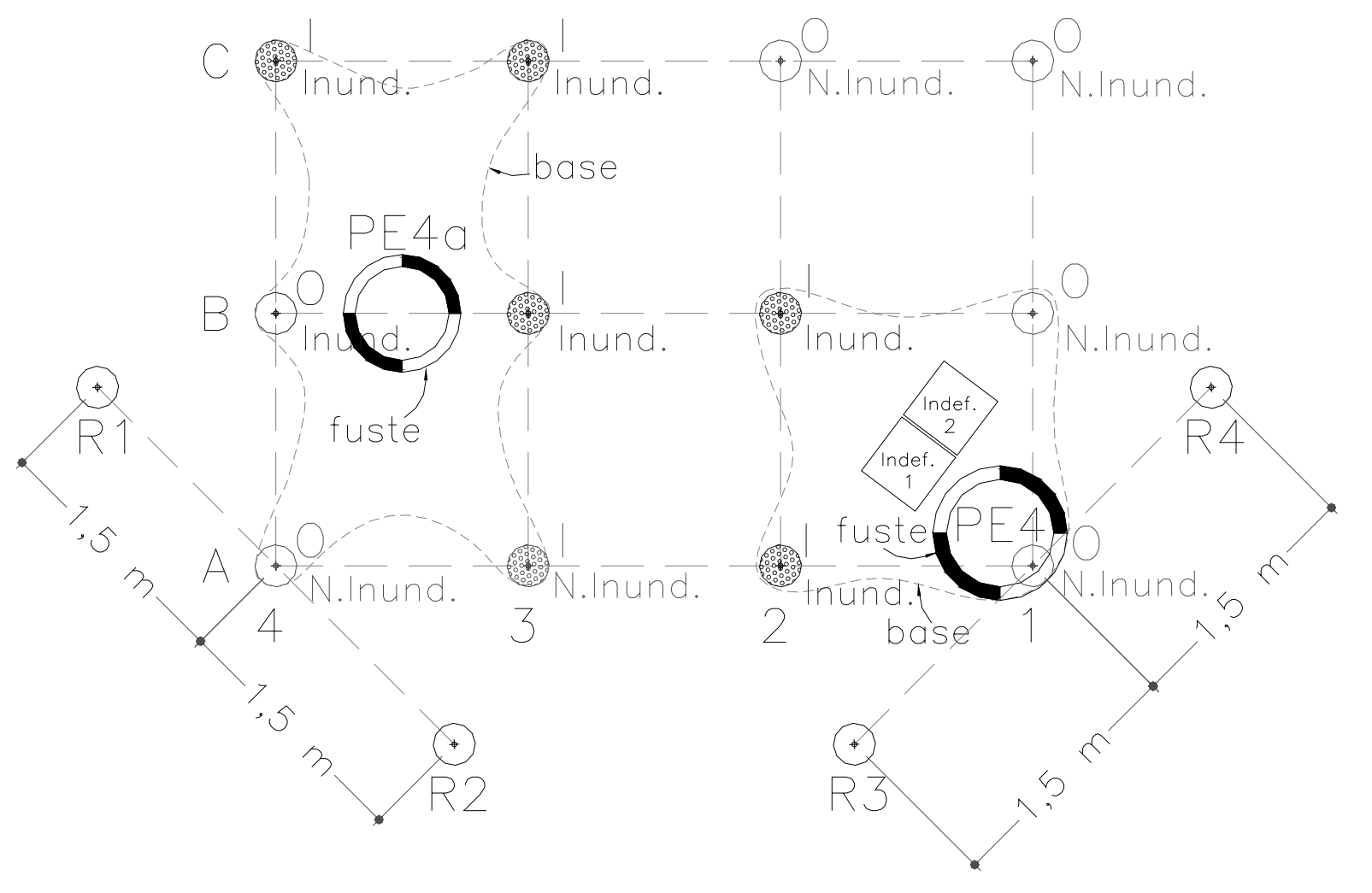

Figura 4.13 - Etapas 1, 2, 3 e 4 - área 4

Figura 4.14 - Etapa 5 - área 5 


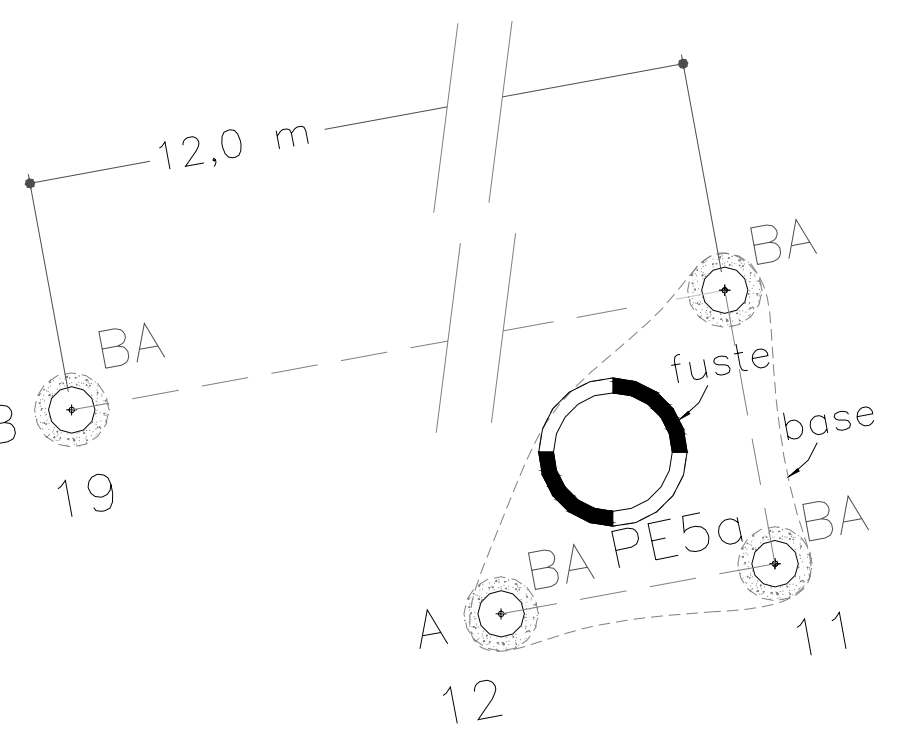

Figura 4.15 - Etapa 6 - área 5

\subsection{1- 1a etapa: PCDs sem inundação}

Esta etapa compreendeu a execução de PCDs em seis estacas da área 4, sem inundação, destinadas à uma outra pesquisa. Destas, foram selecionadas duas PCDs em estacas originais para análise na presente pesquisa. O objetivo foi o de verificar o comportamento de estacas convencionais, na condição de não inundação. As PCDs selecionadas foram as das estacas $\mathrm{A} 1(\mathrm{O})$ e $\mathrm{A} 4(\mathrm{O})$

As armaduras longitudinais das estacas foram soldadas no tubo de cintamento, introduzidas nos furos e feita a concretagem das estacas. Para o controle das especificações do concreto, foi feita a moldagem de oito corpos de prova, que foram ensaiados aos sete e 28 dias de idade. As propriedades de interesse do concreto foram determinadas a partir de seis testemunhos extraídos das estacas B2(I), B4(I) e C1(O) e serviram para a interpretação de todas as PCDs da pesquisa.

\subsection{2- 2ª etapa: PCDs com inundação}

Esta etapa compreendeu a execução de PCDs nas outras seis estacas da área 4, com inundação, destinadas à outra pesquisa. Destas, foi selecionada uma PCD em estaca original 
para análise na presente pesquisa. Também teve como objetivo verificar o comportamento de estacas convencionais, mas sob a condição de inundação. Os demais cuidados e procedimentos foram idênticos aos utilizados na $1^{\underline{a}}$ etapa. As PCDs selecionadas foram as da estaca B4(O).

\subsection{3- 3ำ etapa: PCEs}

Esta etapa compreendeu a execução de PCEs nas estacas A1(O) e A4(O), sem inundação, com inundação e com reensaios, estacas estas que já haviam sido ensaiadas dinamicamente. Teve como objetivo calibrar as PCDs e verificar o efeito da inundação e dos reensaios.

As PCEs foram executadas sob as condições descritas abaixo, no período de 31 de maio a 30 de junho de 2003, após as PCDs anteriores. Apesar de já terem sido ensaiadas dinamicamente, os primeiros ensaios estáticos nestas estacas foram denominados de ensaios:

(a) PCE-1: estaca A4(O), ensaiada em 31 de maio, sem inundação, com incrementos de carga de $15 \mathrm{kN}$, conforme descrito no item 1.3;

(b) PCE-2: estaca A1(O), ensaiada em 4 de junho, sem inundação, com incrementos de carga de $15 \mathrm{kN}$, conforme descrito no item 1.3;

(c) PCE-3: estaca $\mathrm{A} 1(\mathrm{O})$, reensaiada em 7 de junho, com pré-inundação por 48 horas, com incrementos de carga de $15 \mathrm{kN}$, conforme descrito no item 1.3;

(d) PCE-4: estaca $\mathrm{A} 4(\mathrm{O})$, reensaiada em 10 de junho, com pré-inundação por 48 horas, com incrementos de carga de $15 \mathrm{kN}$, conforme descrito no item 1.3;

(e) PCE-5: estaca A4(O), reensaiada em 25 de junho, sem inundação, com um ciclo com incrementos de carga de $50 \mathrm{kN}$, e mais três ciclos rápidos e sucessivos, com 
estágios únicos de carga. O objetivo foi o de provocar um grande deslocamento na ponta da estaca, visando a compressão do solo solto;

(f) PCE-6: estaca A4(O), reensaiada em 30 de junho, sem inundação, com incrementos de carga de $30 \mathrm{kN}$, em um ciclo rápido, buscando encontrar mudança na resistência de ponta, após o deslocamento imposto pela PCE-5.

No dia seguinte ao da PCE-6 executada na estaca A4(O), foi feito um ensaio adicional para verificar se haviam tensões residuais na estaca. Este ensaio consistiu em deixar o topo da estaca livre, reposicionar os relógios comparadores e inundar a cava, anotando-se as leituras dos relógios ao longo do tempo, durante 48 horas, para verificar se ocorreria movimento ascendente no seu topo.

\subsection{4- 4⿳亠丷a etapa: Poços de inspeção e ensaios de laboratório}

Nesta etapa, foram executados dois poços de inspeção (Figura 4.13). O primeiro poço, o PE4 (Figura 4.16), foi utilizado para a remoção da estaca $\mathrm{A} 1(\mathrm{O})$, para a inspeção das pontas das estacas vizinhas e para a coleta de dois blocos de amostras indeformadas.

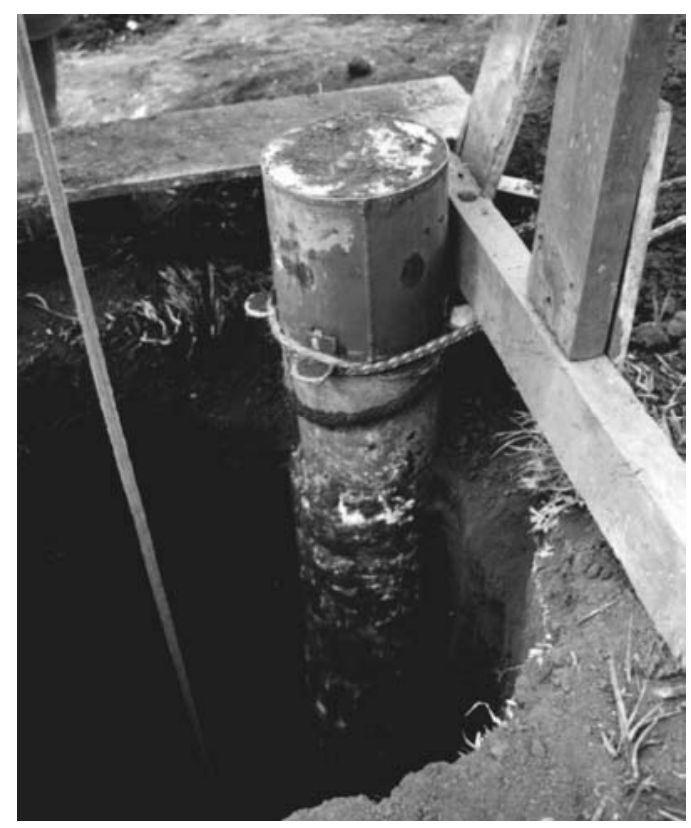

Figura 4.16 - Poço de inspeção PE4 
As estacas com ponta de isopor não foram ensaiadas nesta pesquisa. Foram, apenas, inspecionadas para verificar qualitativamente o estado da sua ponta. As inspeções nas pontas das estacas A2(I), B1(O) e B2(I) foram feitas através da exumação cuidadosa do solo na região da ponta e de registro fotográfico (Figura 4.17).

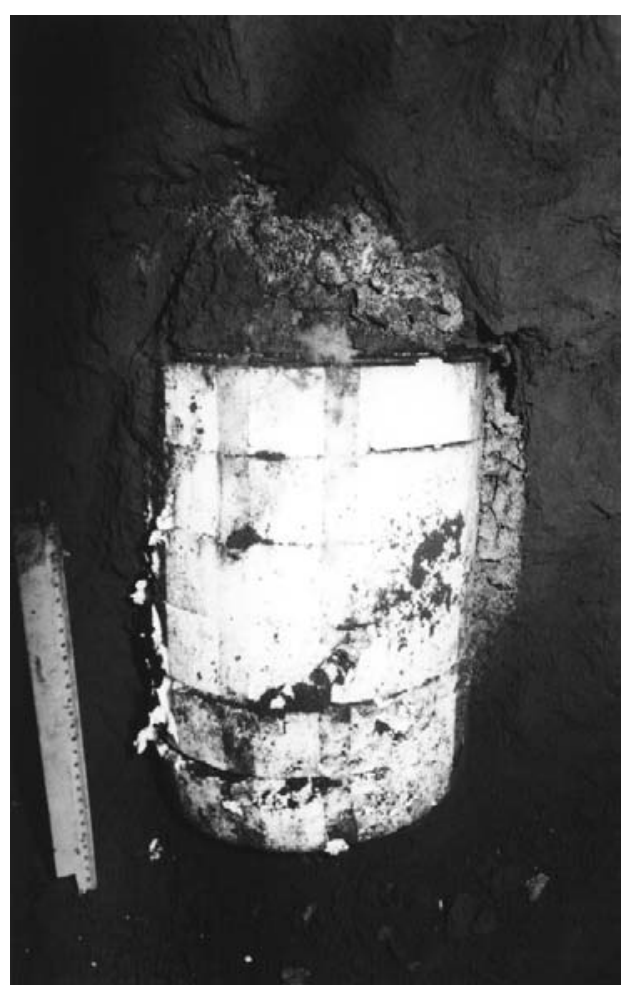

Figura 4.17 - Ponta da estaca B2(I)

A exumação da ponta da estaca B2(I) foi mais detalhada e constou da regularização e planificação, com uma faca, das superfícies escavadas pelo poceiro, limpeza destas superfícies com um pincel e a abertura de uma trincheira de face vertical, seccionando progressivamente a seção da escavação, com o objetivo de expor progressivamente a perfuração resultante e os resíduos acumulados no seu fundo.

A Figura 4.18 ilustra esta seqüência. Na foto da esquerda pode ser vista a diferença entre o solo natural e o solo solto, que foi, posteriormente, removido com as mãos. Na foto da direita pode ser visto o aspecto final da exumação, com as superfícies da escavação já limpas pelo pincel. 

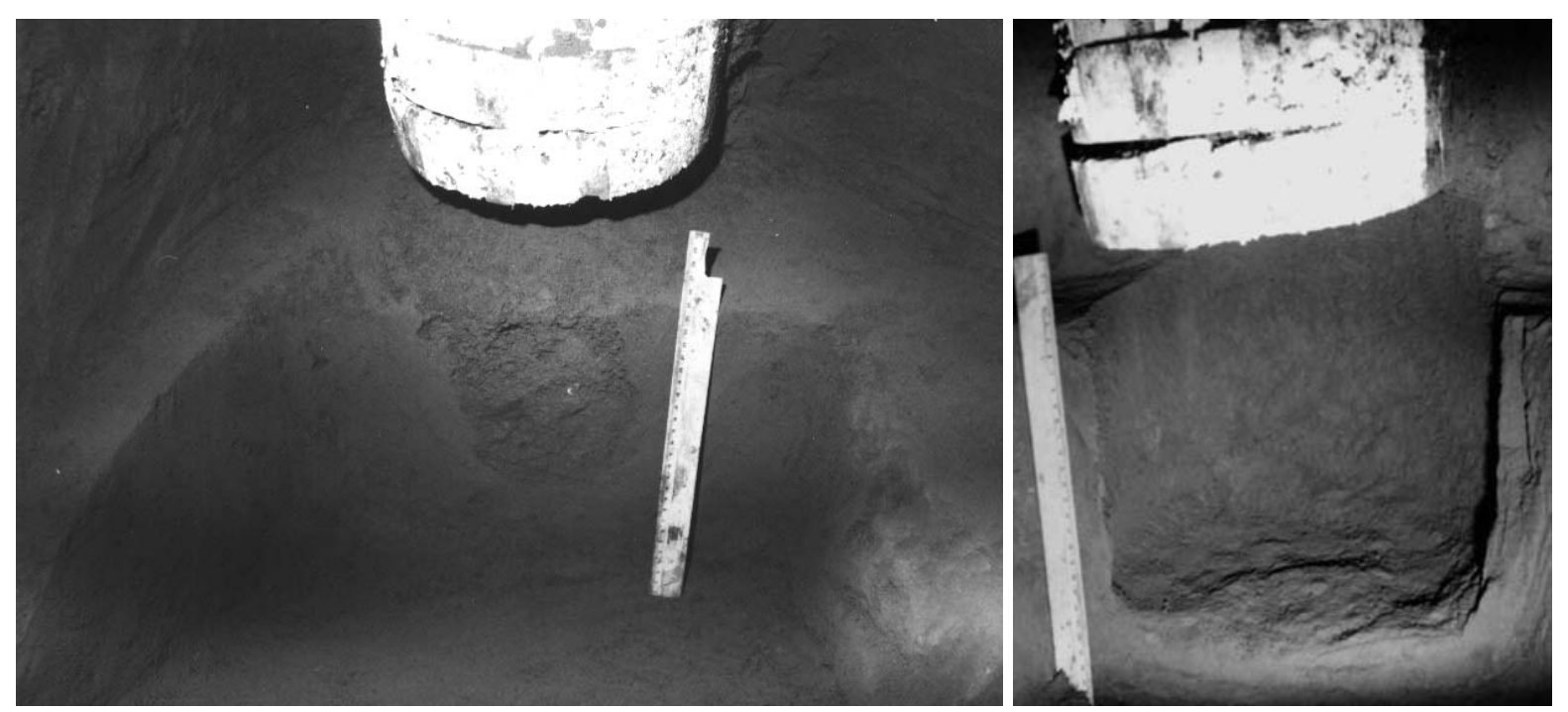

Figura 4.18 - Seqüência da exumação do solo sob a ponta da estaca B2(I)

Ao lado do PE4 foi feita uma escavação piloto, como se fosse para executar uma estaca de forma tradicional, porém sem a sua concretagem. Esta escavação foi denominada de Ala e teve como objetivo a verificação da eventual ocorrência de resíduos no seu fundo. Ao término da escavação, foi colocado um disco de papelão no fundo, com a finalidade de separar a eventual queda posterior de detritos. A partir da base do PE4, foi aberto um "túnel de acesso" ligeiramente acima do fundo desta escavação, feita a limpeza dos detritos sobre o disco de papelão provenientes da escavação do "túnel”, colocado um grampo metálico para marcar sua posição, removido este disco, feita a remoção dos detritos acumulados no fundo da escavação com as mãos e feita a medida desta profundidade. A Figura 4.19 ilustra esta seqüência.
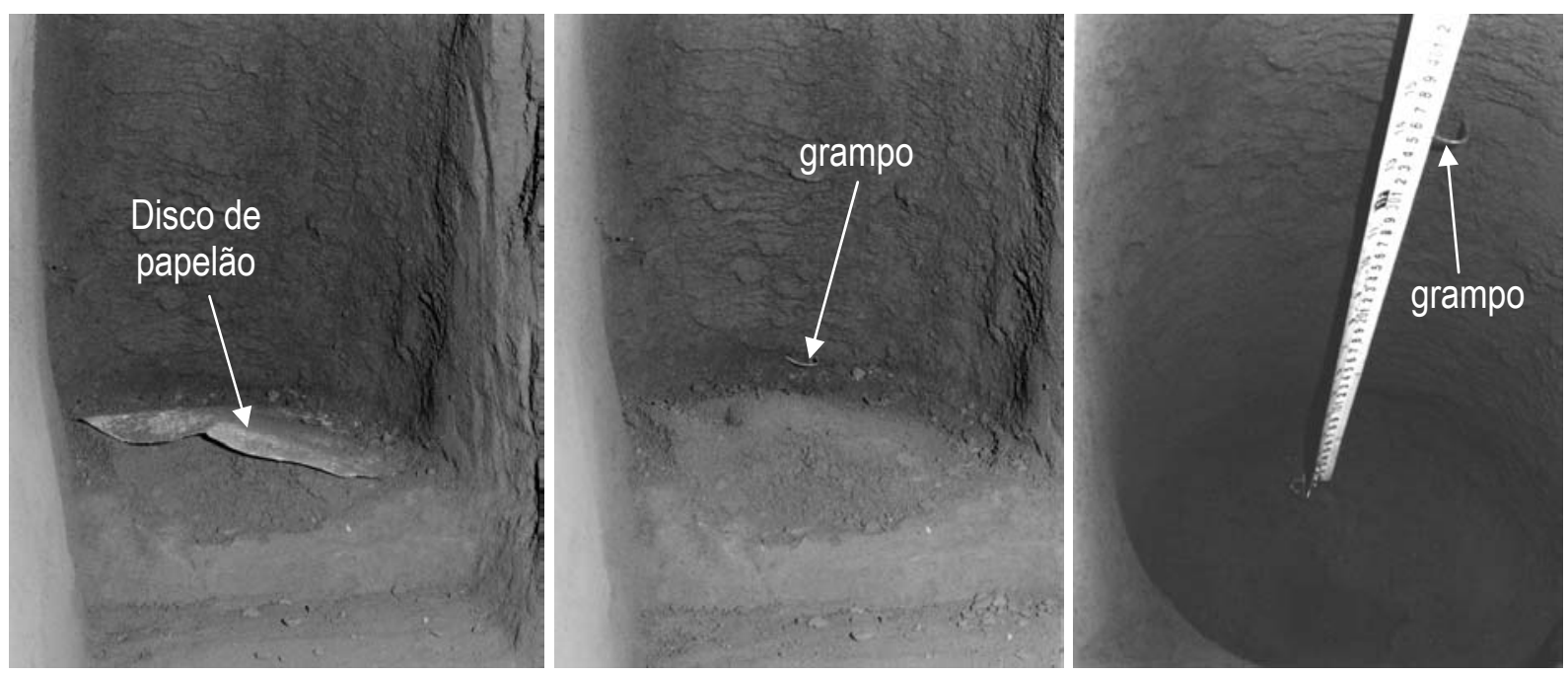

Figura 4.19 - Seqüência da inspeção da ponta da escavação piloto (A1a) 
O segundo poço (PE4a) foi utilizado apenas para a inspeção visual das pontas das estacas A3(I), A4(O), B3(I), B4(O), C3(I) e C4(I) e confirmou o padrão obtido no poço PE4.

Os blocos de amostras indeformadas coletados no poço PE4 foram parafinados, protegidos e transportados ao laboratório de Geotecnia da EESC/USP para ensaios. No laboratório, foram talhados os corpos de prova, nos quais foram executados ensaios triaxiais com sucção controlada (Figuras 4.20 e 4.21).

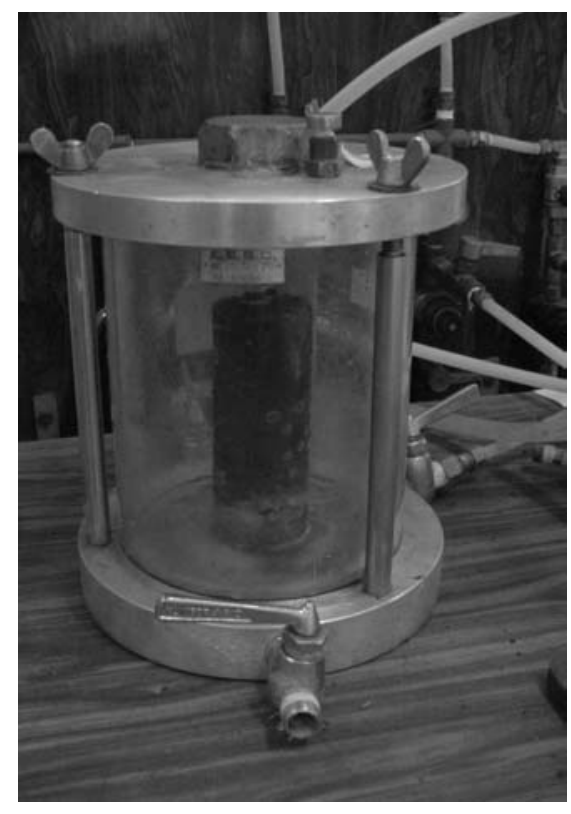

Figura 4.20 - Câmara de sucção

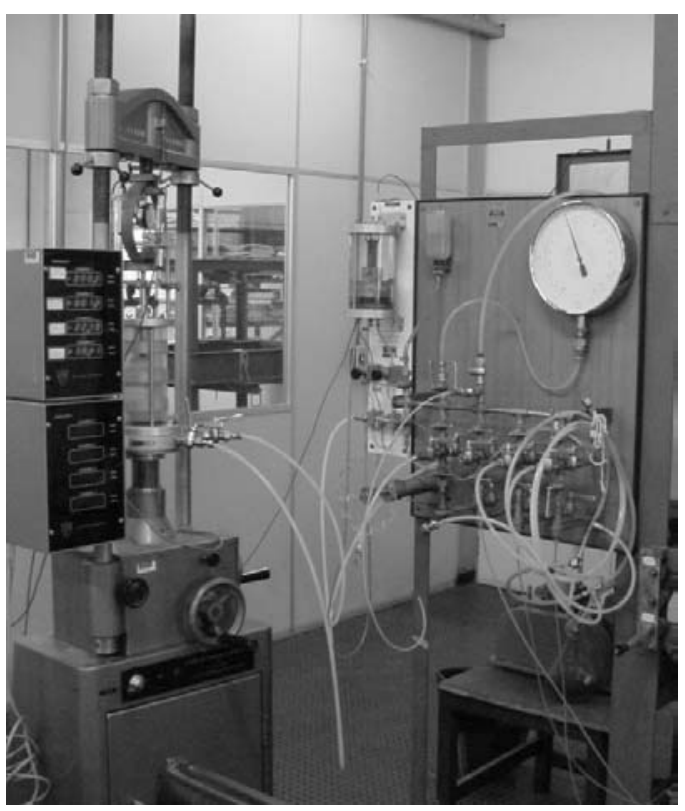

Figura 4.21 - Ensaio triaxial com sucção controlada

As tensões confinantes variaram de $50 \mathrm{kPa}$ a $310 \mathrm{kPa}$ e as sucções de $0 \mathrm{kPa}$ (condição de saturação) até $150 \mathrm{kPa}$, procurando recriar as condições de campo para a avaliação do comportamento do solo na profundidade da ponta das estacas.

\subsection{5- 5a etapa: PCDs em estacas com ponta modificada, poço de inspeção e ensaios de laboratório}

Esta etapa compreendeu a execução de nove estacas, divididas em três grupos de estacas com três tipos diferentes de modificação da ponta, com intervenção em grau crescente em relação à redução de vazios do solo solto e a execução de PCDs nestas estacas, sem inundação. Após as 
PCDs, foi escavado o poço PE5, para a remoção da estaca B9(SM), para a inspeção das pontas das estacas A8(SM), A9(BS) e B8(LC) e para a coleta de quatro blocos de amostras indeformadas, sob a ponta destas quatro estacas (Figuras 4.14, 4.32 a 4.37).

A Figura 4.14 mostra a posição destes blocos que, na seqüência, foram levados ao laboratório, para a execução de ensaios. Teve como objetivo avaliar o desempenho dos três tipos de modificação da ponta empregado, em condições normais, sem inundação.

Os tipos de modificação da ponta adotados foram os seguintes:

(a) (LC): Ponta limpa com uma caçamba construída para este fim, feita com um tubo de aço dotado de fundo com duas lâminas para a coleta dos detritos. Foi acoplada à ponta do trado, através de um engate com um pino de aço (Figuras 4.22 a 4.25);

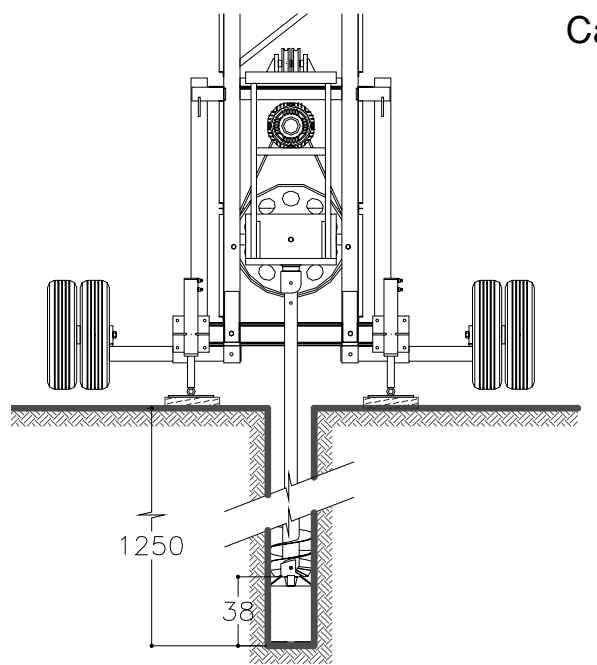

Caçamba na ponta do trado

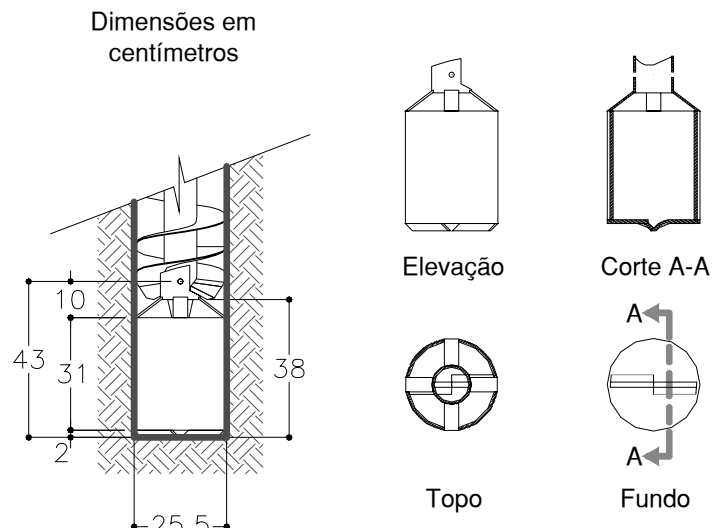

Figura 4.22 - Desenho do equipamento e detalhes da caçamba 


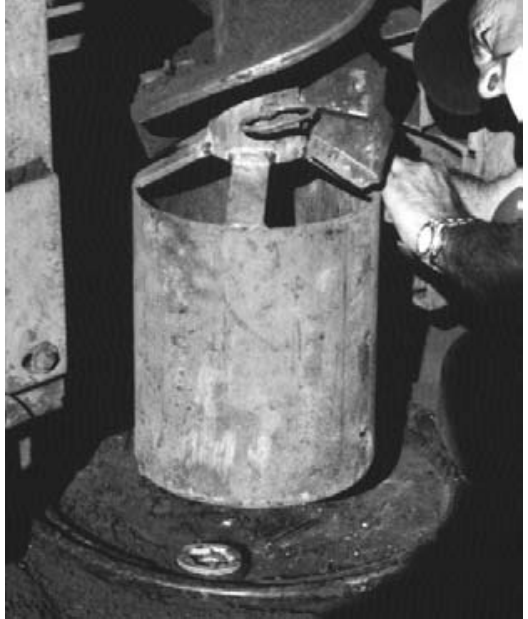

Figura 4.23 - Caçamba vazia

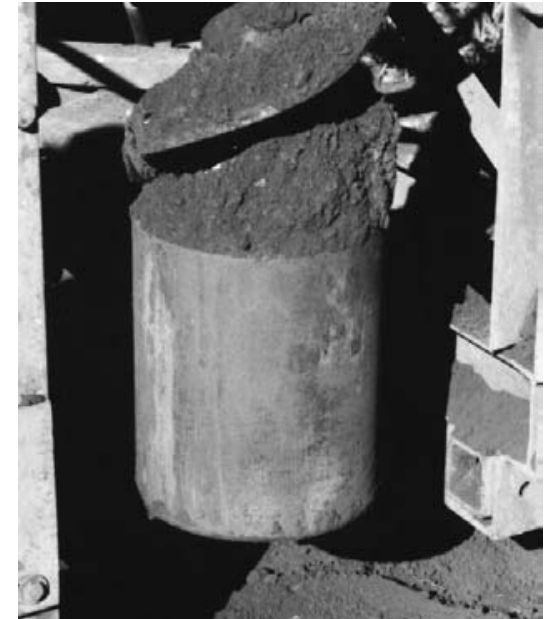

Figura 4.24 - Caçamba cheia

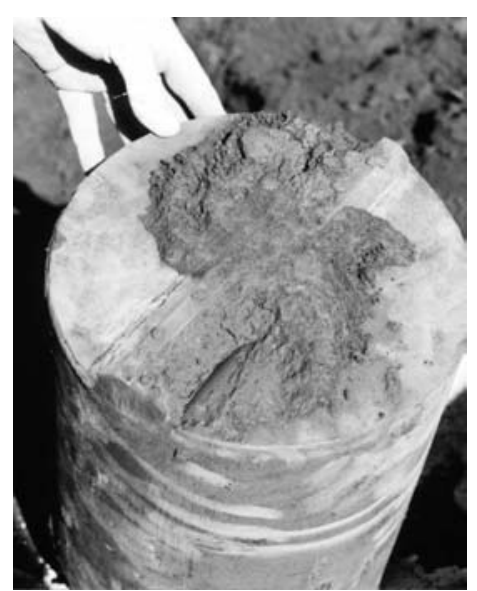

Figura 4.25 - Vista do fundo

(b) (SM): Ponta com solo melhorado através da adição de $300 \mathrm{~cm}^{3}$ de biocatalizador estabilizante de solos EMC $^{2}$ (BASE FORTE, 2004), diluído na proporção de 1:100, no fundo da escavação e compactação do solo solto com soquete de equipamento Strauss. O biocatalisador é um produto que, segundo seu distribuidor, atua num "processo que envolve a adsorsão, a co-polimerização, a troca iônica, as ligações covalentes e a micro-encapsulação das partículas do solo, garantindo uma coesão ideal do material compactado, sua densificação e sua proteção contra a infiltração de umidade". A altura de queda do soquete variou entre 1,0 e 1,5 m, para uma média de seis golpes e um "afundamento" do solo solto de cerca de 0,4 m. As Figuras 4.26 e 4.27 ilustram o biocatalizador nos estados bruto e já preparado para o uso e a Figura 4.28 ilustra a caneca utilizada para a aplicação do produto diretamente no fundo da escavação; 


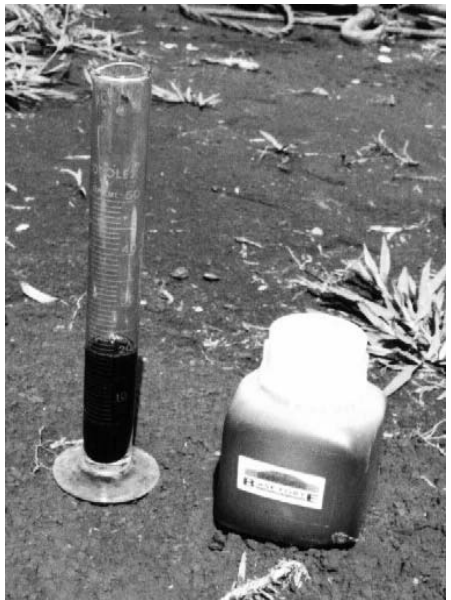

Figura 4.26 - Biocatalizador bruto

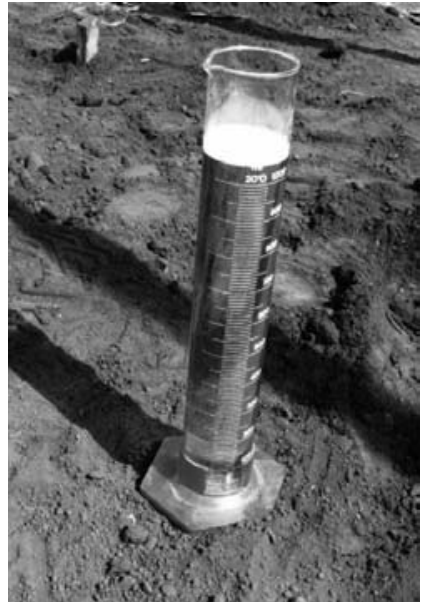

Figura 4.27 - Produto preparado

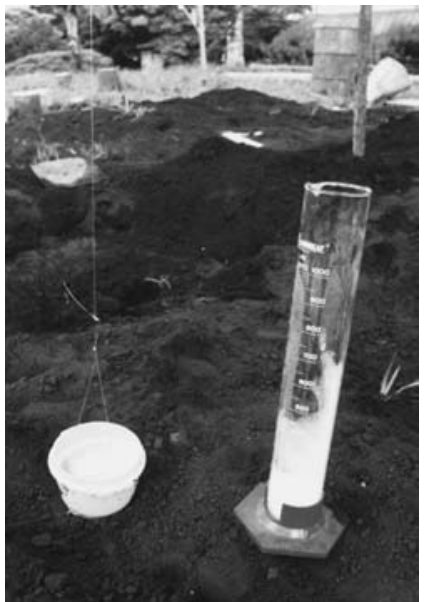

Figura 4.28 - Caneca para aplicação

(c) (BS): Execução de uma "bucha" na ponta, com o procedimento semelhante ao que é adotado na execução da ponta de estacas Strauss. Foi utilizado um traço em volume de 1,5:1,5:1 (britas 1 e 2, areia média lavada e cimento), com leve umedecimento. A compactação foi feita sem revestimento e com oito golpes com altura de queda entre 1,0 e 1,5 m. As Figuras 4.29 e 4.30 ilustram a execução da "bucha de Strauss".

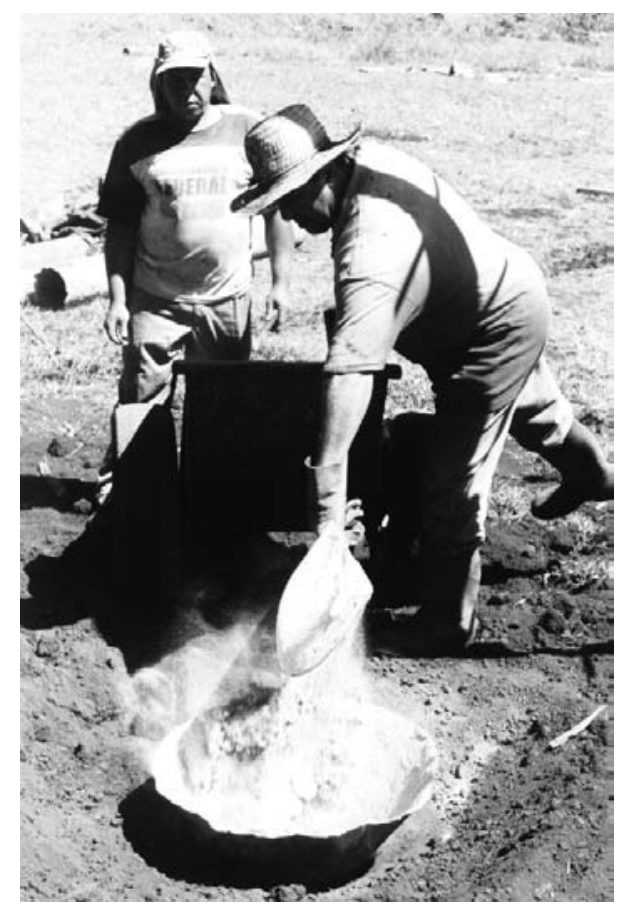

Figura 4.29 - Material para a bucha

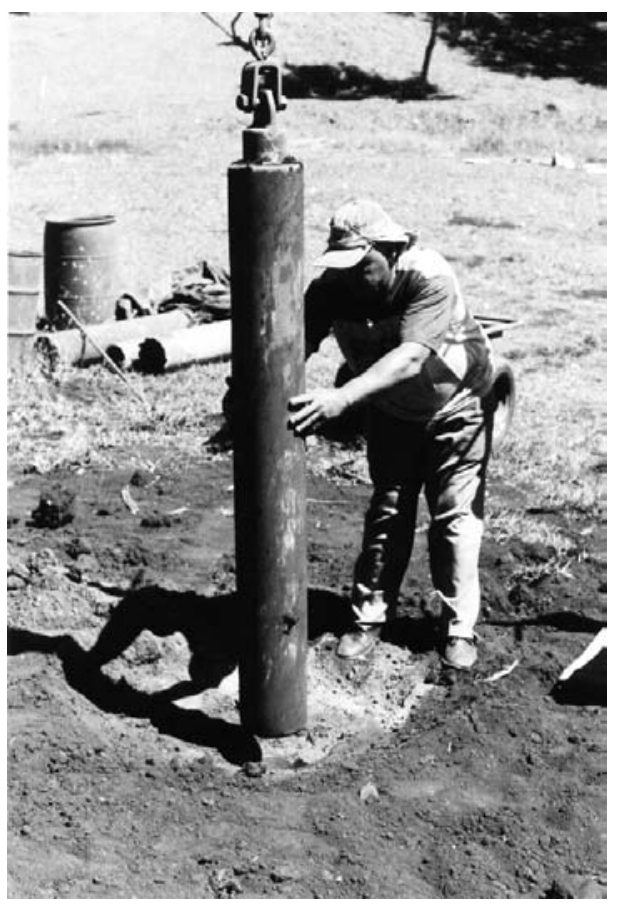

Figura 4.30 - Detalhe do soquete de Strauss 
Antes das modificações das pontas, o fundo da escavação da estaca A10 foi inspecionado através de uma câmera de vídeo, construída para este fim e denominada de UT-01 (Figura $4.31)$.

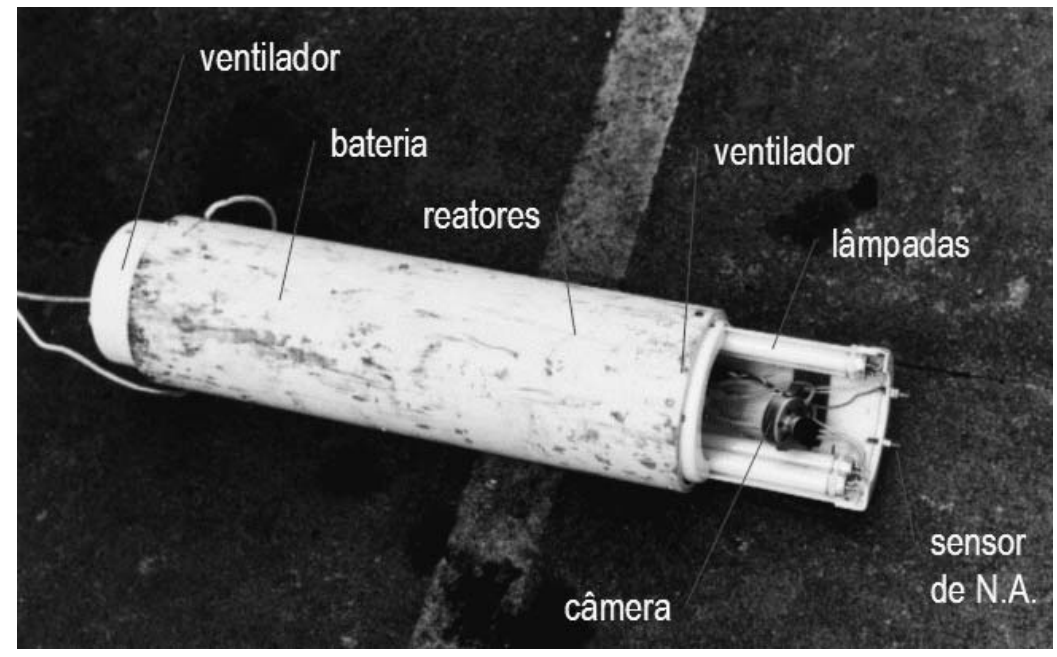

Figura 4.31 - Protótipo da câmera de vídeo UT-01

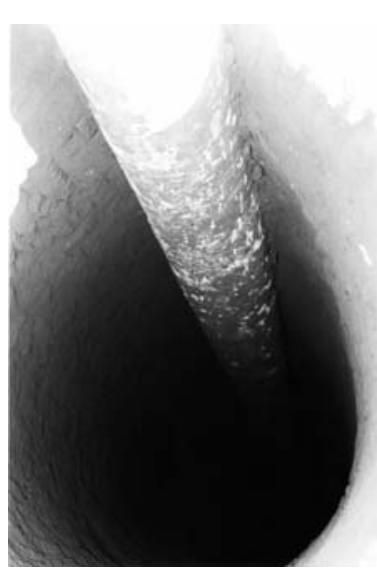

Figura 4.32 - Poço PE5

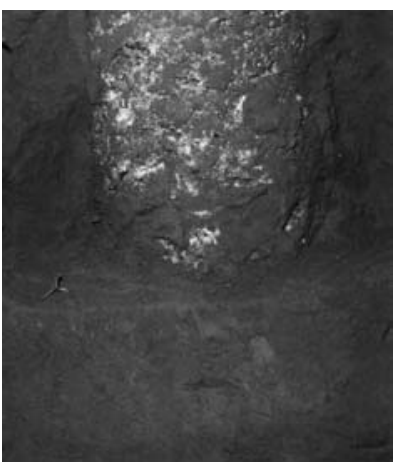

Figura 4.34 - Bloco $\mathrm{A} 8(\mathrm{SM})$

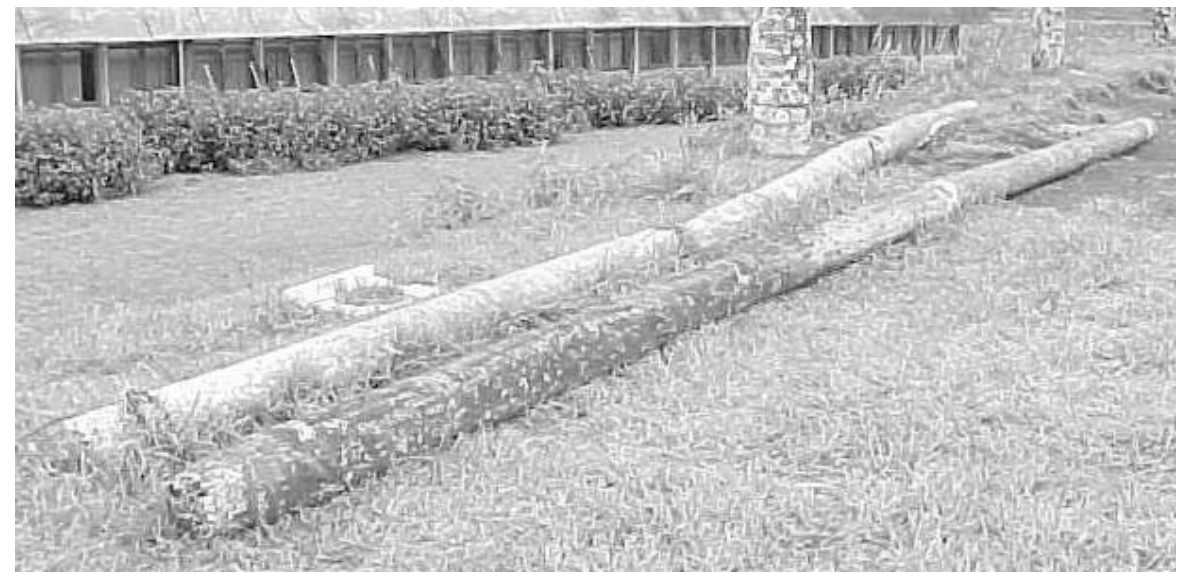

Figura 4.33 - Estacas $\mathrm{A} 1(\mathrm{ON})$ e $\mathrm{B} 9(\mathrm{SM})$ removidas

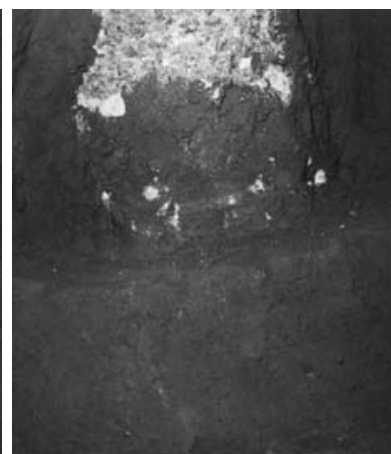

Figura 4.35 - Bloco A9(BS)

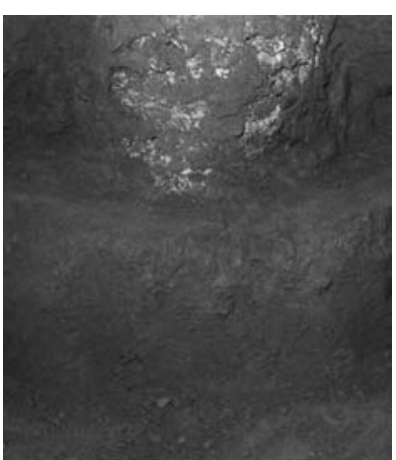

Figura 4.36 - Bloco B8(LC)

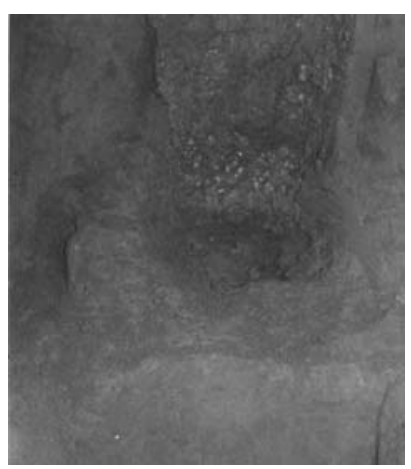

Figura 4.37 - Bloco B9(SM) 
A programação dos ensaios compreendeu a execução, no laboratório de Geotecnia da UEL, de ensaios para a determinação da massa específica do solo ao longo da altura dos blocos e de ensaios triaxiais, tipo CD drenado ao ar, em amostras coletadas em distâncias radialmente crescentes.

As determinações da massa específica foram feitas pelo método da balança hidrostática em corpos de prova retirados no eixo das estacas, espaçados verticalmente de $7 \mathrm{~cm}$. No capítulo 5 “Resultados: Apresentação e análise" será feita uma observação com relação à determinação das massas específicas do solo da ponta da estaca B9(SM). Os ensaios triaxiais foram do tipo CD, drenados ao ar, (Figuras 4.38 e 4.39).

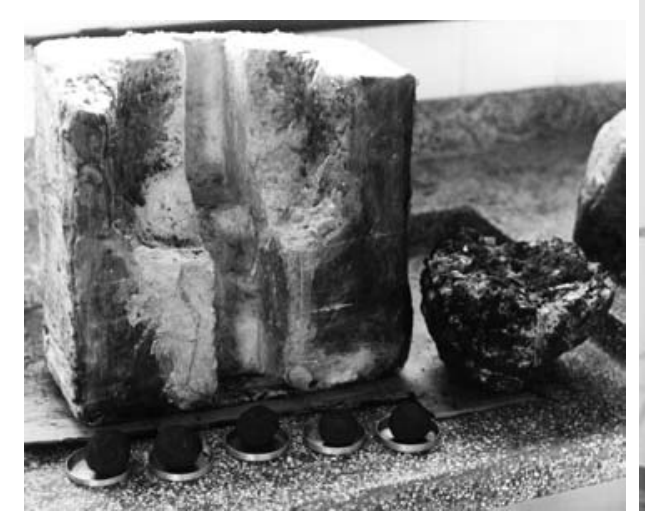

Figura 4.38 - Bloco sob a estaca B9(SM)

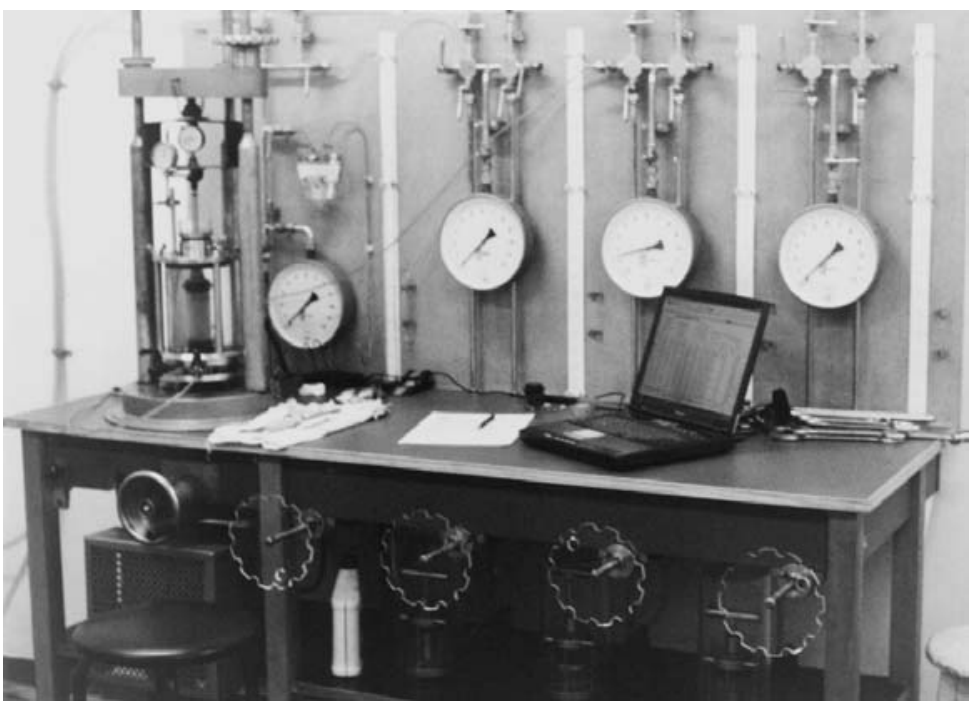

Figura 4.39 - Ensaio triaxial, tipo CD drenado ao ar, em andamento

O objetivo destes ensaios foi o de investigar a influência dos métodos de modificação empregados, em função da distância da ponta da estaca. 


\subsection{6- 6a etapa: PCDs e poço de inspeção}

Esta etapa compreendeu a execução de quatro estacas com a utilização de um equipamento denominado Tip Improvement-01 (TI-01), construído com o objetivo de buscar uma forma alternativa de ponta modificada de estacas escavadas. Este tipo de modificação proposta foi feito através do alargamento da base e compactação do fundo, de forma estática e identificada pela sigla (BA).

O princípio de funcionamento baseou-se na abertura de lâminas no fundo da escavação para providenciar reação para a compactação estática do solo solto no fundo, possibilitando, ainda, aumento da área de ponta. A Figura 4.40 mostra a vista geral do equipamento, com a unidade hidráulica ao lado. A Figura 4.41 ilustra a seqüência da abertura das suas lâminas e a Figura 4.42 ilustra a seqüência da descida da sua base.

Após a utilização do TI-01 nas bases das estacas A11 e B11, estas foram inspecionadas visualmente com a câmera de vídeo UT-01, agora aperfeiçoada para permitir movimento basculante e equipada com leds de alta potência que acompanham o movimento da câmera (figura 4.43). 


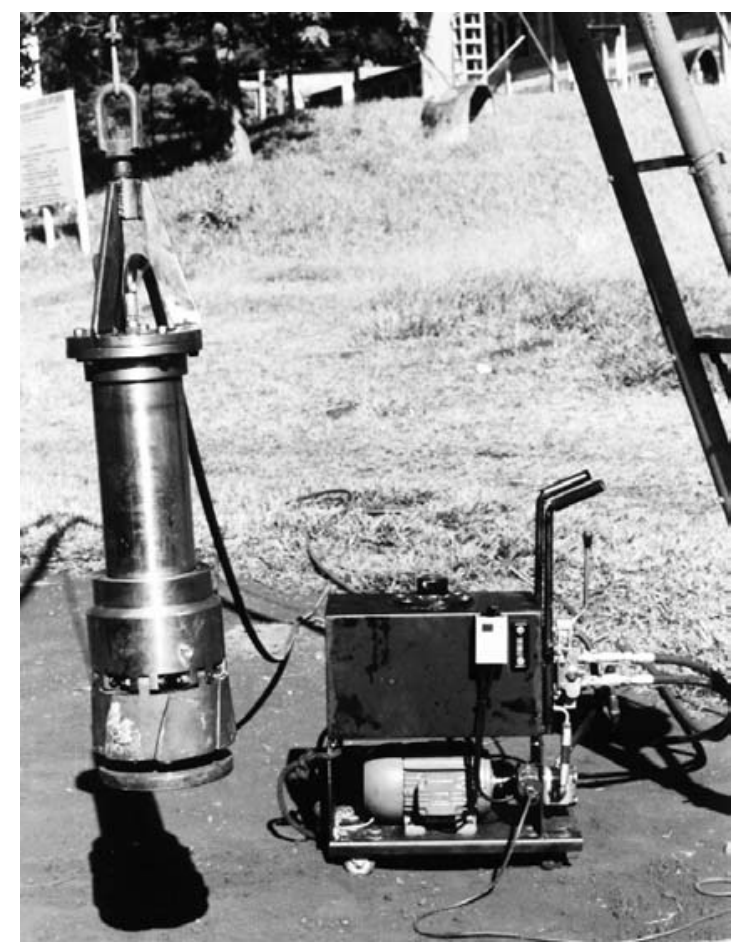

Figura 4.40 - Vista geral do equipamento

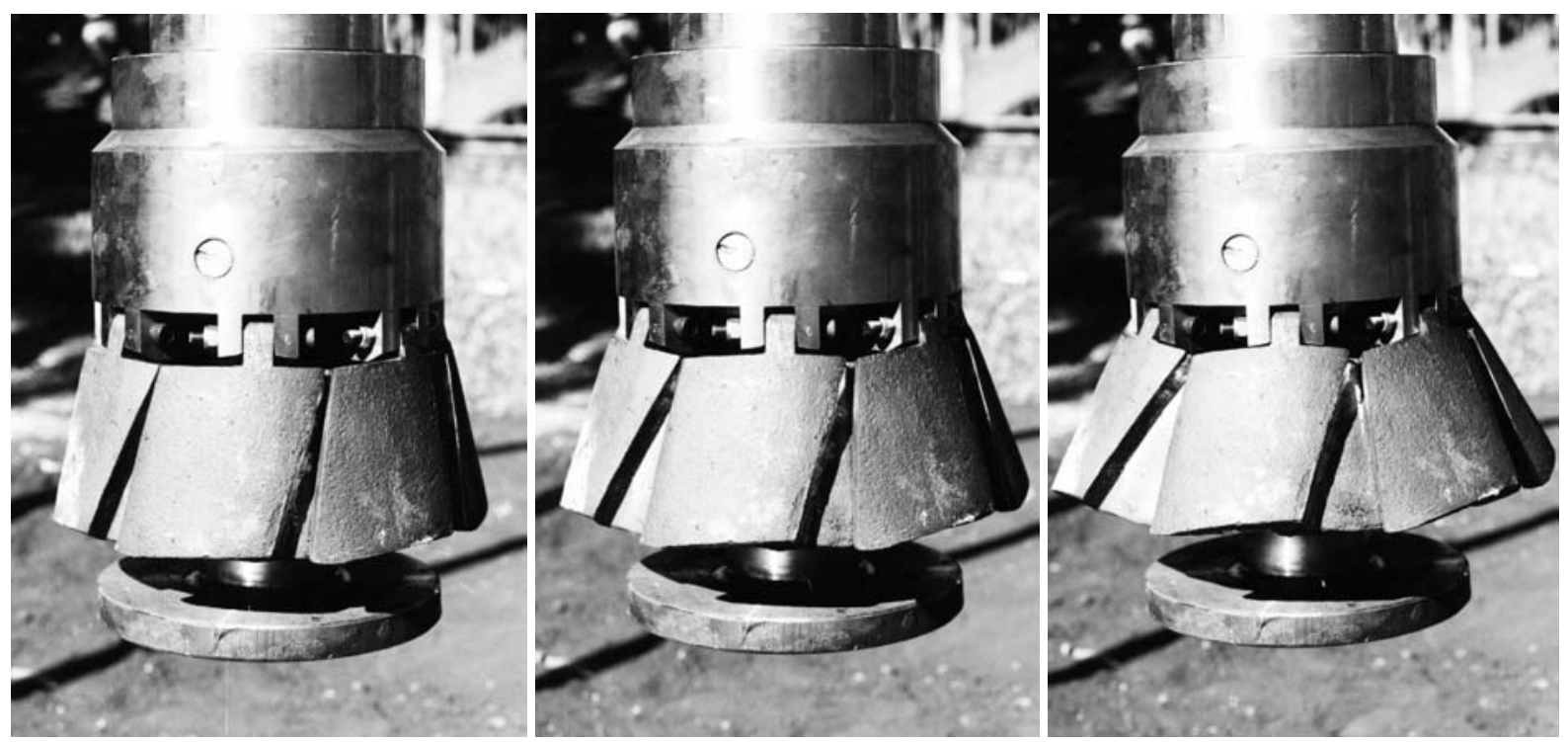

Figura 4.41 - Seqüência da abertura das lâminas do equipamento 


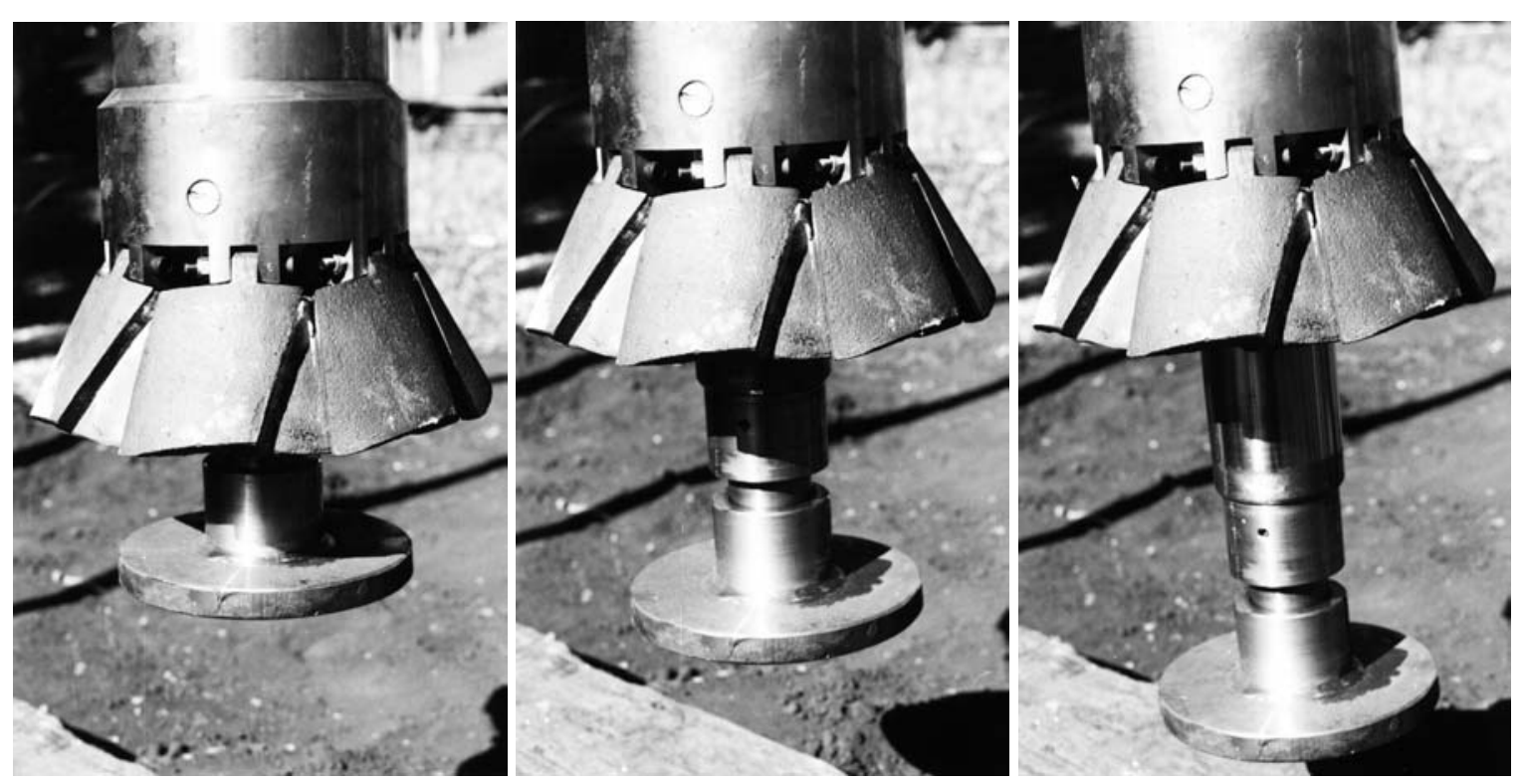

Figura 4.42 - Seqüência da descida da base do equipamento

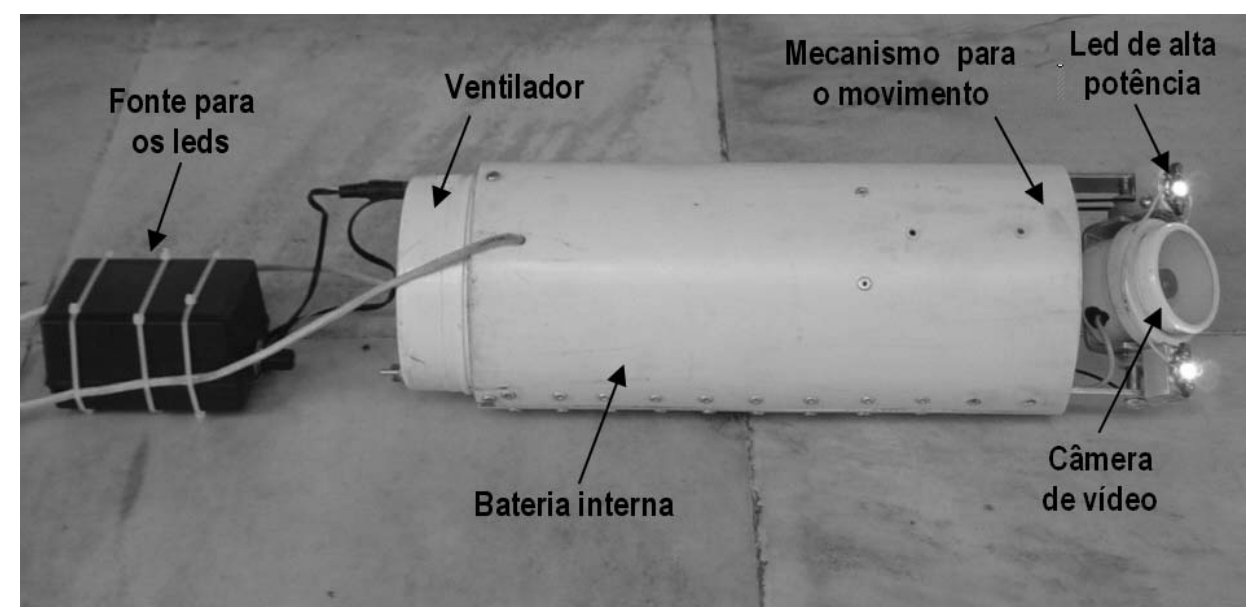

Figura 4.43 - Câmera de vídeo UT-01 aperfeiçoada

As estacas foram concretadas seguindo-se os mesmos procedimentos e materiais adotados para as anteriores.

Foram executadas PCDs nas quatro estacas, sendo três sem inundação e uma com inundação. Após as PCDs, foi aberto o poço PE5a (Figura 4.15) para a inspeção das pontas das estacas A11, A12 e B11.

O resumo de todas as estacas ensaiadas na pesquisa é mostrado na Tabela 4.1. 
Tabela 4.1 - Áreas 4 e 5: Resumo das estacas ensaiadas

\begin{tabular}{|c|c|c|c|c|c|c|c|c|c|c|c|c|c|c|c|}
\hline \multicolumn{5}{|c|}{ Características das estacas } & \multicolumn{11}{|c|}{ Características dos ensaios } \\
\hline \multirow[b]{2}{*}{ nome } & \multirow[b]{2}{*}{ preparo da ponta } & \multirow[b]{2}{*}{ sigla } & \multirow[b]{2}{*}{$\phi(\mathrm{cm})$} & \multirow[b]{2}{*}{ prof. (m) } & & & & \multirow[b]{2}{*}{ carregamento } & \multicolumn{7}{|c|}{ Pré-inundação } \\
\hline & & & & & \multicolumn{3}{|c|}{ tipo } & & $1^{0}$ & $2^{0}$ & $3^{0}$ & $4^{0}$ & $5^{\circ}$ & $6^{0}$ & total \\
\hline A1 & original & (0) & 25 & 12 & PCD & vert. & compressão & DIET & $\mathrm{N}$ & $\mathrm{N}$ & & & & & 2 \\
\hline A4 & original & (0) & 25 & 12 & PCD & vert. & compressão & DIET & $N$ & $\mathrm{~N}$ & & & & & 2 \\
\hline B4 & original & (0) & 25 & 12 & PCD & vert. & compressão & DIET & 1 & I & & & & & 2 \\
\hline A4 & original & (0) & 25 & 12 & PCE & vert. & compressão & QML & & & $\mathrm{N}$ & & & & 1 \\
\hline $\mathrm{A} 1$ & original & (0) & 25 & 12 & PCE & vert. & compressão & QML & & & $\mathrm{N}$ & & & & 1 \\
\hline A1 & original & (0) & 25 & 12 & PCE & vert. & compressão & QML & & & & I & & & 1 \\
\hline A4 & original & (0) & 25 & 12 & PCE & vert. & compressão & QML & & & & 1 & & & 1 \\
\hline A4 & original & (0) & 25 & 12 & PCE & vert. & compressão & QML & & & & & $\mathrm{N}$ & & 1 \\
\hline A4 & original & (0) & 25 & 12 & PCE & vert. & compressão & QML & & & & & & $\mathrm{N}$ & 1 \\
\hline $\mathrm{A} 10$ & "bucha de Strauss" & (BS) & 25 & 12 & PCD & vert. & compressão & DIET & $N$ & $\mathrm{~N}$ & & & & & 2 \\
\hline $\mathrm{B} 10$ & limpa com caçamba & $(\mathrm{LC})$ & 25 & 12 & PCD & vert. & compressão & DIET & $N$ & $\mathrm{~N}$ & & & & & 2 \\
\hline $\mathrm{C} 10$ & solo melhorado & (SM) & 25 & 12 & PCD & vert. & compressão & DIET & $N$ & $\mathrm{~N}$ & & & & & 2 \\
\hline A9 & "bucha de Strauss" & (BS) & 25 & 12 & PCD & vert. & compressão & DIET & $N$ & $\mathrm{~N}$ & & & & & 2 \\
\hline B8 & limpa com caçamba & $(\mathrm{LC})$ & 25 & 12 & PCD & vert. & compressão & DIET & $\mathrm{N}$ & $\mathrm{N}$ & & & & & 2 \\
\hline B9 & solo melhorado & (SM) & 25 & 12 & PCD & vert. & compressão & DIET & $N$ & $\mathrm{~N}$ & & & & & 2 \\
\hline C8 & limpa com caçamba & $(\mathrm{LC})$ & 25 & 12 & PCD & vert. & compressão & DIET & $N$ & $\mathrm{~N}$ & & & & & 2 \\
\hline C9 & "bucha de Strauss" & (BS) & 25 & 12 & PCD & vert. & compressão & DIET & $N$ & $\mathrm{~N}$ & & & & & 2 \\
\hline A8 & solo melhorado & (SM) & 25 & 12 & PCD & vert. & compressão & DIET & $\mathrm{N}$ & $\mathrm{N}$ & & & & & 2 \\
\hline A11 & base alargada & (BA) & 25 & 12 & PCD & vert. & compressão & DIET & $N$ & $\mathrm{~N}$ & & & & & 2 \\
\hline B11 & base alargada & $(\mathrm{BA})$ & 25 & 12 & PCD & vert. & compressão & DIET & $N$ & $\mathrm{~N}$ & & & & & 2 \\
\hline $\mathrm{C} 11$ & base alargada & $(\mathrm{BA})$ & 25 & 12 & PCD & vert. & compressão & DIET & $\mathrm{N}$ & $\mathrm{N}$ & & & & & 2 \\
\hline B19 & base alargada & $(\mathrm{BA})$ & 25 & 12 & PCD & vert. & compressão & DIET & 1 & I & & & & & 2 \\
\hline
\end{tabular}




\section{5- RESULTADOS: APRESENTAÇÃO E ANÁLISE}

\section{1- Previsão da capacidade de carga}

Para efeito de pré-dimensionamento dos experimentos e posterior comparação com os resultados obtidos nas provas de carga, foi feita a previsão da capacidade de carga pelos métodos semi-empíricos de Aoki-Velloso (1975) e Décourt-Quaresma (1978), este modificado por Décourt (1996). Os resultados obtidos estão mostrados na Tabela 5.1.

Tabela 5.1 - Resultados das previsões de capacidade de carga

\begin{tabular}{ccccc}
\hline Método & Solo & $\boldsymbol{R}_{\boldsymbol{L}}(\mathbf{k N})$ & $\boldsymbol{R}_{\boldsymbol{P}}(\mathbf{k N})$ & $\boldsymbol{R}_{\boldsymbol{U}}(\mathbf{k N})$ \\
\hline Aoki-Velloso (1975) & Argila siltosa & 71 & 52 & 123 \\
\hline Décourt (1996) & Argila siltosa & 207 & 65 & 172 \\
\hline & Médias & 139 & 59 & 198 \\
\hline
\end{tabular}

A previsão da distribuição de carga ao longo da estaca foi feita pelo método Aoki-Velloso, a partir dos resultados do CPT14 (Figura 5.1). Os motivos da escolha deste ensaio foram pelos fatos deste furo ser o CPT mais próximo das estacas ensaiadas e porque os SPTs só determinam o valor de $\mathrm{N}$ a partir de $1 \mathrm{~m}$ de profundidade, o que representa um prejuízo à estimativa da distribuição de carga para estas estacas, uma vez que a porção superior do terreno é caracterizada por um aterro, conforme pode ser observado nos resultados da resistência de ponta do cone $\left(\mathrm{q}_{\mathrm{c}}\right)$ e do atrito lateral $\left(\mathrm{f}_{\mathrm{s}}\right)$. 


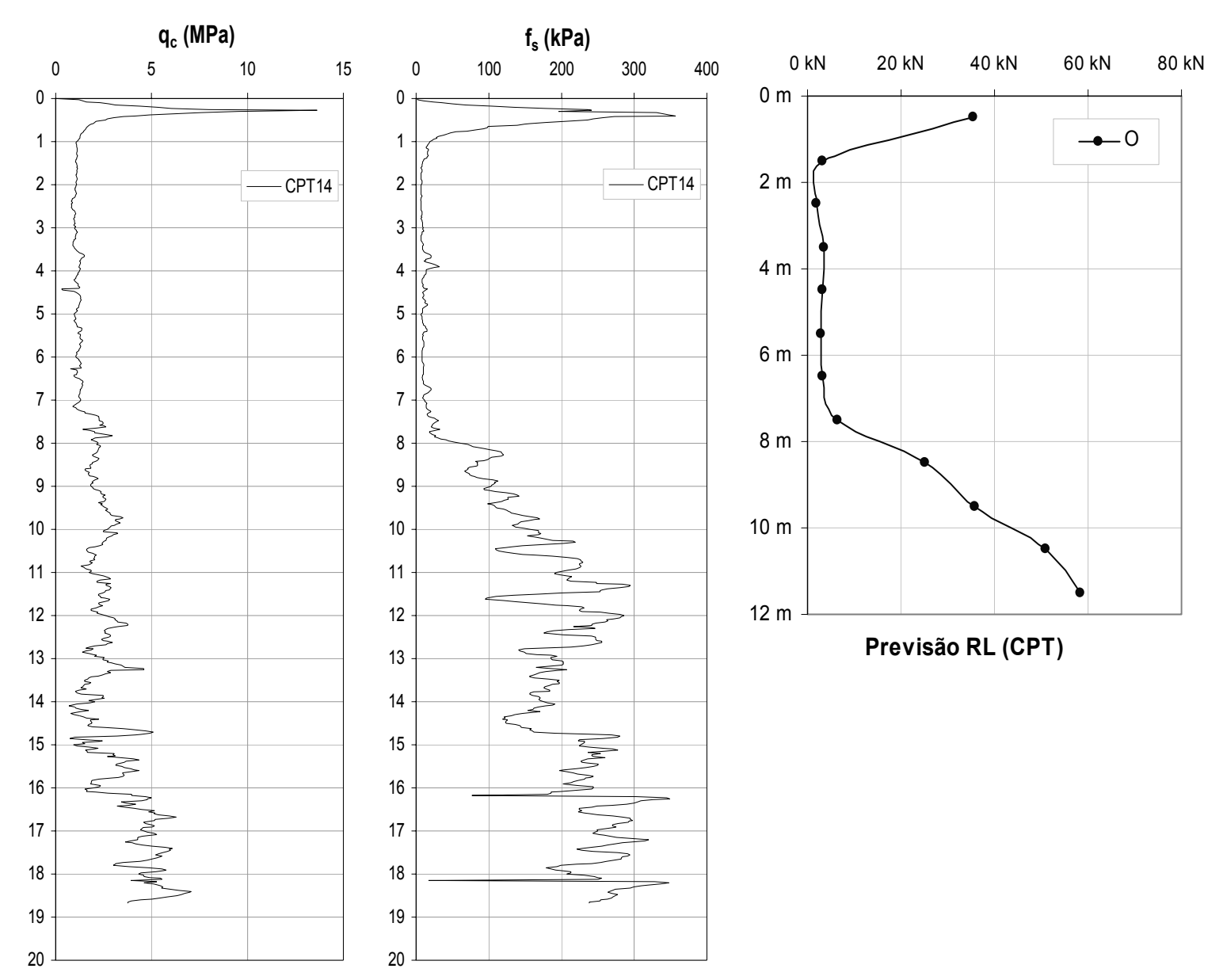

Figura 5.1 - Resultados do CPT14 e a previsão de distribuição de carga ao longo da estaca

Como conseqüência, a previsão de distribuição de carga indicou um elevado valor de atrito lateral no primeiro metro.

\section{2- Propriedades do concreto das estacas}

A determinação das propriedades do concreto das estacas foi feita a partir de seis testemunhos extraídos das estacas B2(I), B4(I) e C1(O), que foram retificados com êmbolos diamantados, para prover possibilitar a planicidade, o paralelismo e a perpendicularidade sugeridos pela ISRM (1978). Os corpos de prova foram ensaiados, segundo programação de carregamento e demais prescrições da NBR-8522 (2003), com o uso de instrumentação, conforme Figura 5.2. 


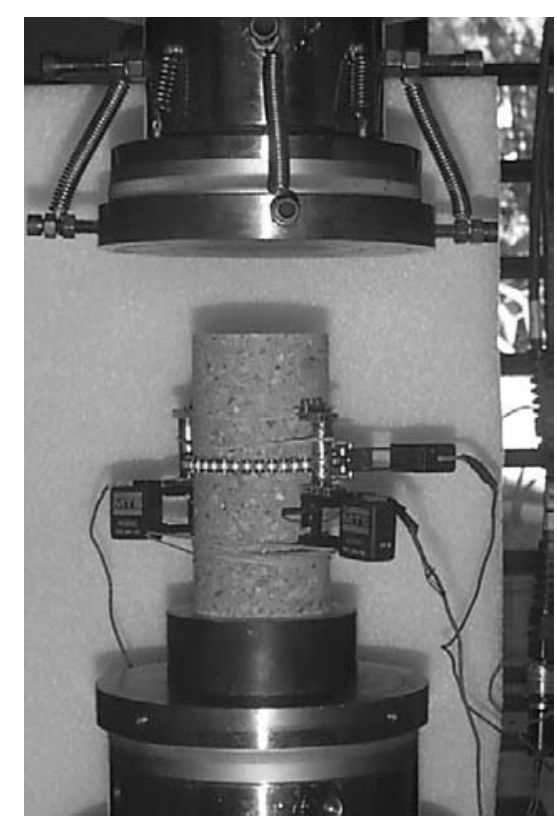

Figura 5.2 - Ensaio para determinação das propriedades mecânicas do concreto

A programação de carregamento do estágio 1 foi composta de cinco ciclos de carga e descarga com $\sigma \leq 0,5 \mathrm{MPa}$ e $\sigma_{\text {sup }}=0,3 \times f_{c}$ do concreto, tendo apresentado $\sigma_{\text {sup }}=6,3 \mathrm{MPa}$. Neste estágio foram determinados os valores de deformação relativa axial e radial para a obtenção dos valores de $(E$ e $v)$. A seguir, o carregamento foi levado até cerca de $60 \%$ da carga última $f_{c}$ (Estágio 2) e, em seguida, o corpo de prova foi descarregado totalmente, removida a instrumentação e carregado até a ruptura (Estágio 3), para determinar qual a sua resistência real $f_{c}$. O módulo de deformação estática foi determinado através da equação 5.1 .

$$
E=2 \times \frac{\sigma_{\text {sup }}-\sigma_{\text {inf }}}{\varepsilon_{0,3}-\varepsilon_{0}+\varepsilon_{0,3}^{\prime}-\varepsilon_{0}^{\prime}}
$$

Os resultados obtidos foram:

$$
\begin{array}{ll}
\text { - } f_{\text {c28 médio }}=21,2 \mathrm{MPa} & \mathrm{s}=0,61 \mathrm{MPa} \\
\text { - } E_{\text {médio }}=22,3 \mathrm{GPa} & \mathrm{s}=1,87 \mathrm{GPa} \\
\text { - } \gamma=24 \mathrm{kN} / \mathrm{m}^{3} &
\end{array}
$$

Estes parâmetros foram utilizados nos ajustes dos sinais do PDA, para a correta interpretação das PCDs. Para tanto, inicialmente foram adotados os valores obtidos em laboratório para o 
peso específico e para o módulo de elasticidade do concreto, respectivamente, $\gamma$ e $E$. Mantendo-se fixo o valor de $\gamma$, procuraram-se pequenos ajustes no $E$ (de maior dificuldade e imprecisão de determinação), para que as velocidades da onda calculada e da medida fossem iguais $(W S=W C$ ), condição que representa o elemento estrutural de concreto como íntegro e sem fissuras.

\section{3- Provas de carga dinâmica (PCDs)}

As estacas foram ensaiadas, através de provas de carga dinâmica com energia crescente, em lotes de acordo com as etapas da pesquisa, entre novembro de 2002 e março de 2006. Para permitir o acompanhamento da possível influência da sucção nos resultados, a pluviosidade no período está sempre explicitada, por meio de tabelas, no início da apresentação destes resultados. Um sinal ajustado típico está ilustrado na Figura 5.3.

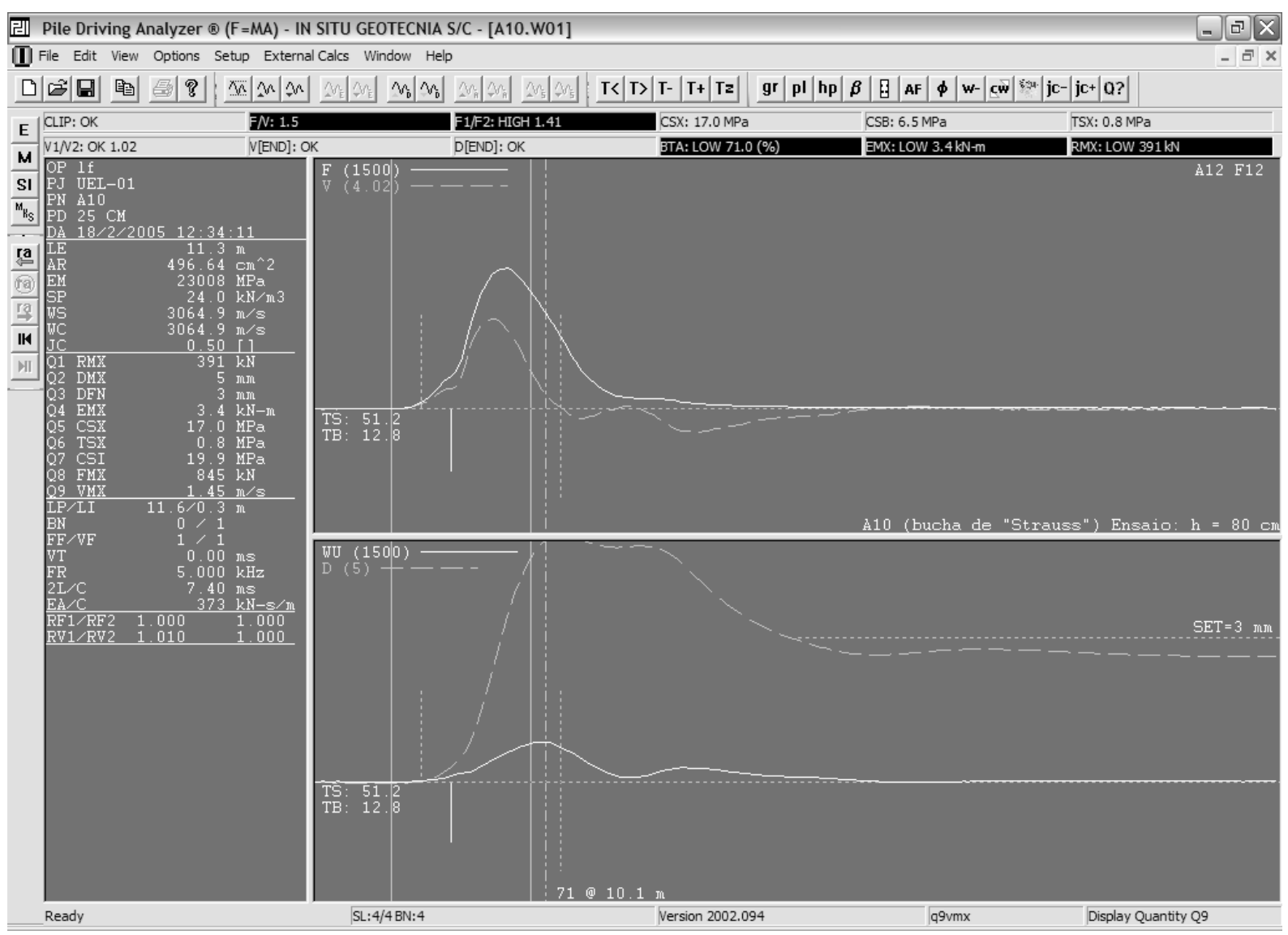

Figura 5.3 - Sinal ajustado do 4 - golpe, na estaca A10(BS) 
Um resultado típico de análise CAPWAP está ilustrado na Figura 5.4.

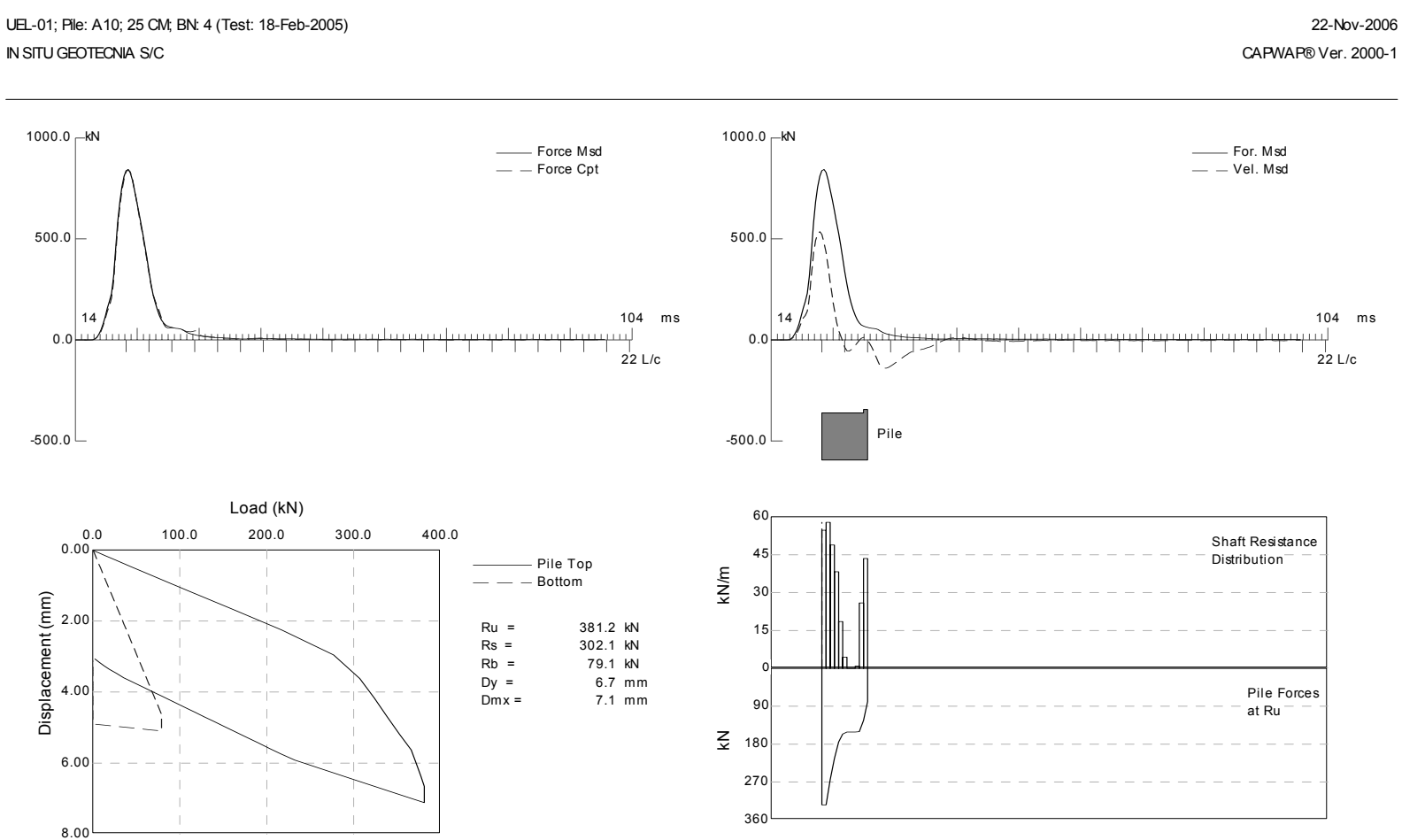

Figura 5.4 - Análise CAPWAP do 4 ํ golpe, na estaca A10(BS

A seguir, estão apresentados os resultados das PCDs de cada uma das etapas da pesquisa, em termos de curvas carga versus DMX e de gráficos tridimensionais de distribuição da carga ao longo das estacas (Figuras 5.5 a 5.28 e 5.30 a 5.37).

Os gráficos de distribuição de carga estão à direita das curvas carga versus DMX. A energia dos golpes está representada no eixo transversal $(\mathrm{kJ})$, o valor das cargas no eixo vertical $(\mathrm{kN})$ e o comprimento da estaca no eixo longitudinal (m).

\subsection{1- 1ํㅡㄹ etapa: Estacas do tipo original (0), sem inundação}

As estacas da $1^{\underline{a}}$ etapa foram ensaiadas, sem pré-inundação, nos dias 2 e 3 de novembro de 2002 e, imediatamente após as PCDs iniciais, foram reensaiadas. A pluviosidade nos dois dias que as antecederam e nos dias dos ensaios está mostrada na Tabela 5.2. 
Tabela 5.2 - Pluviosidade no período das PCDs - 1aㅡ etapa (2002)

\begin{tabular}{crccc}
\hline Dia & 31/out & 01/nov & 02/nov $^{(P C D s)}$ & 03/nov \\
& (PCDs) \\
\hline Pluviosidade $(\mathbf{m m})$ & 1,3 & 0,0 & 0,0 & 0,0 \\
\hline
\end{tabular}

As Figuras 5.5 a 5.8 apresentam os resultados dos ensaios executados nas estacas A1(O) e A4(O), selecionadas desta etapa, sem pré-inundação.
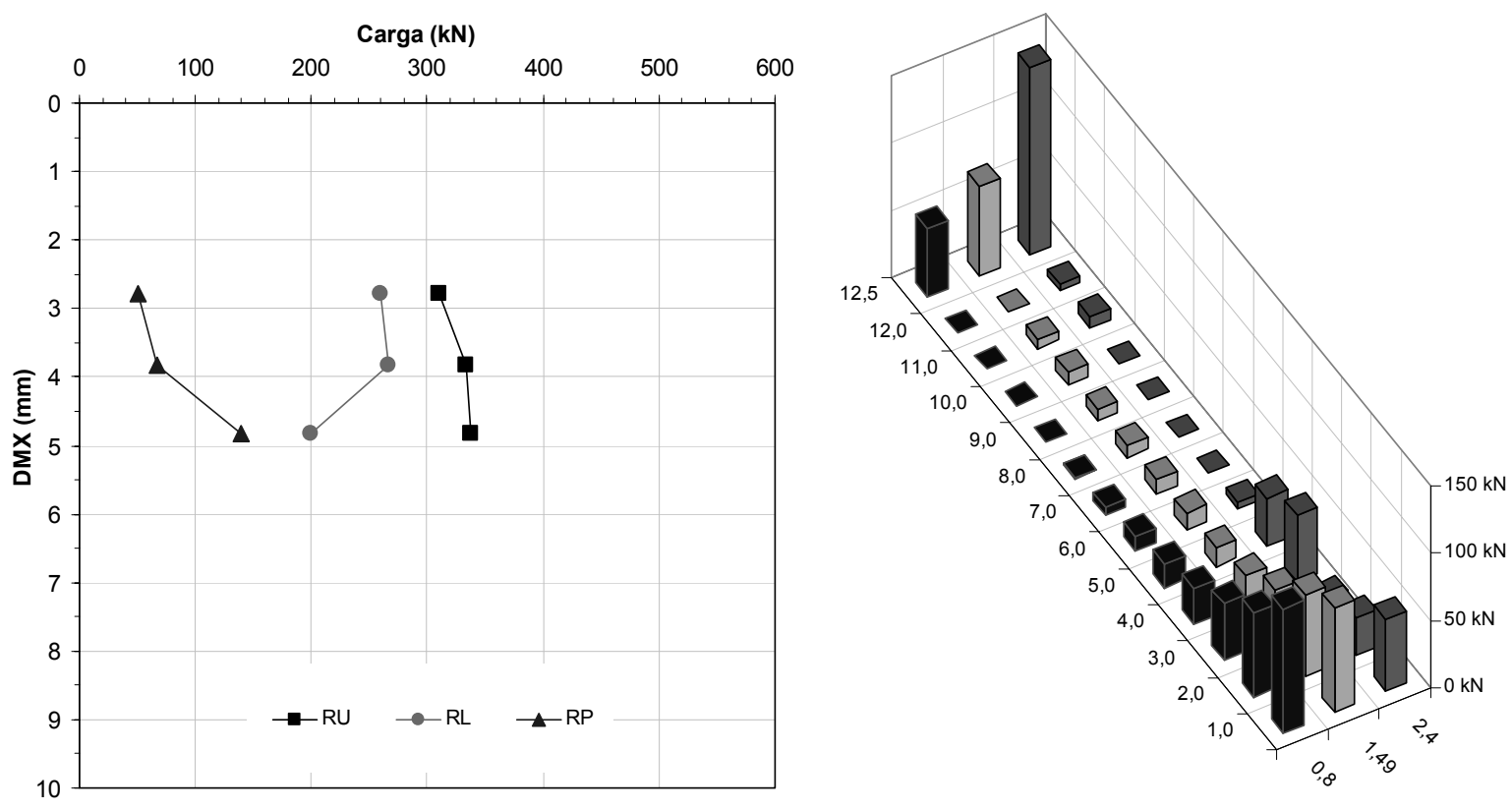

Figura 5.5 - Prova de carga dinâmica na estaca $A 1(0)$ - Ensaio, sem pré-inundação
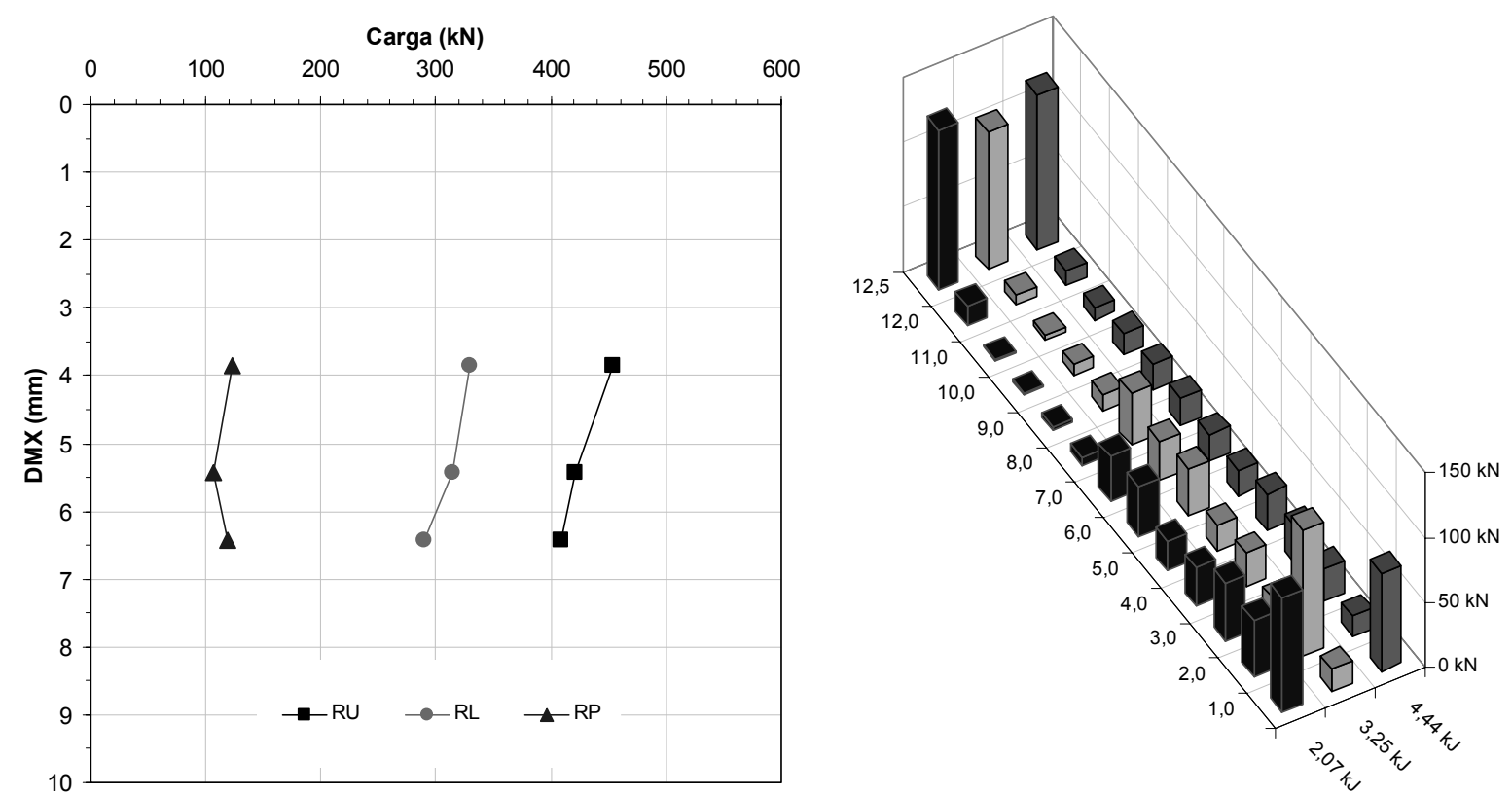

Figura 5.6 - Prova de carga dinâmica na estaca $A 1(0)$ - Reensaio, sem pré-inundação 


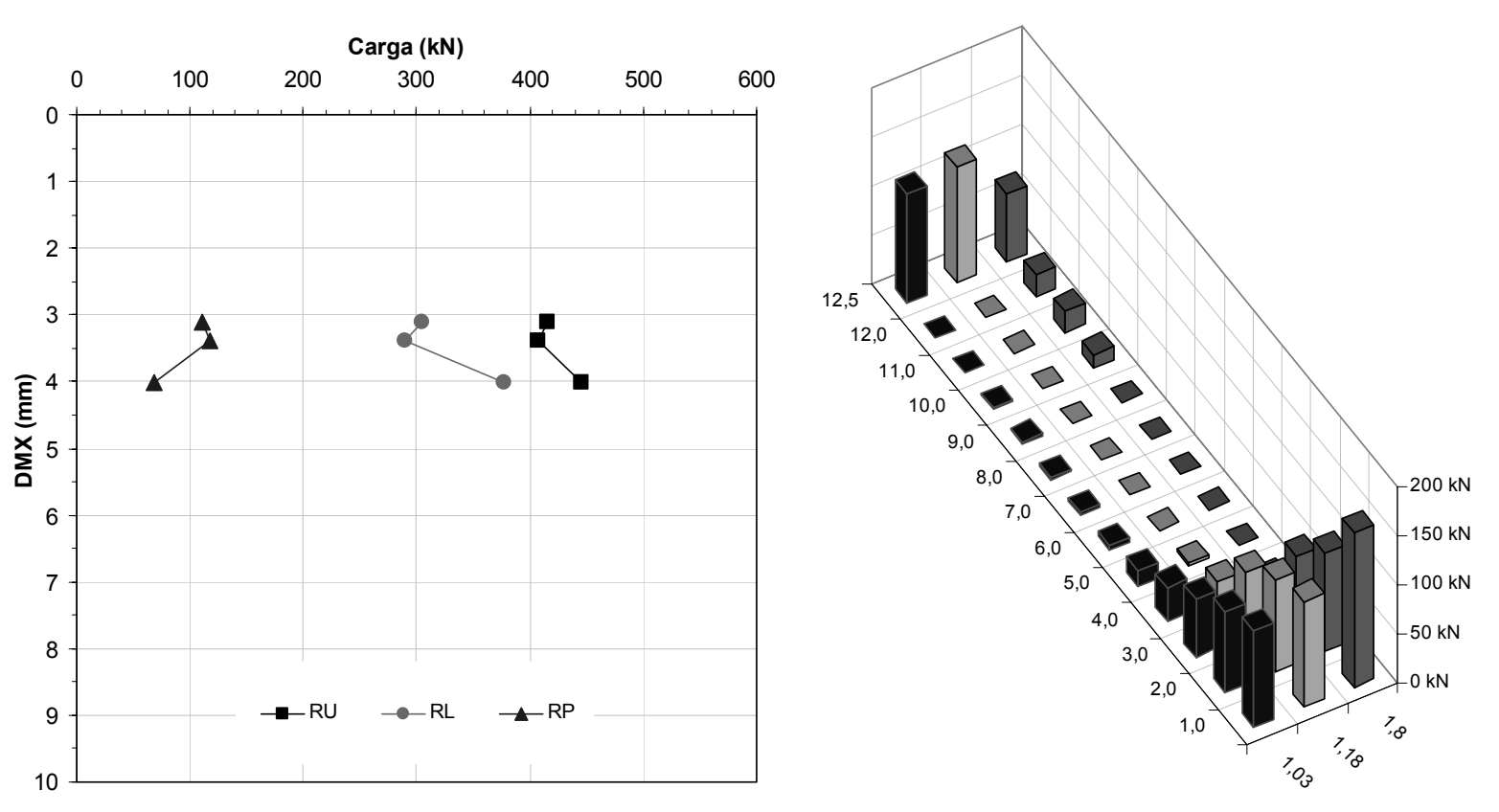

Figura 5.7 - Prova de carga dinâmica na estaca A4(0) - Ensaio, sem pré-inundação
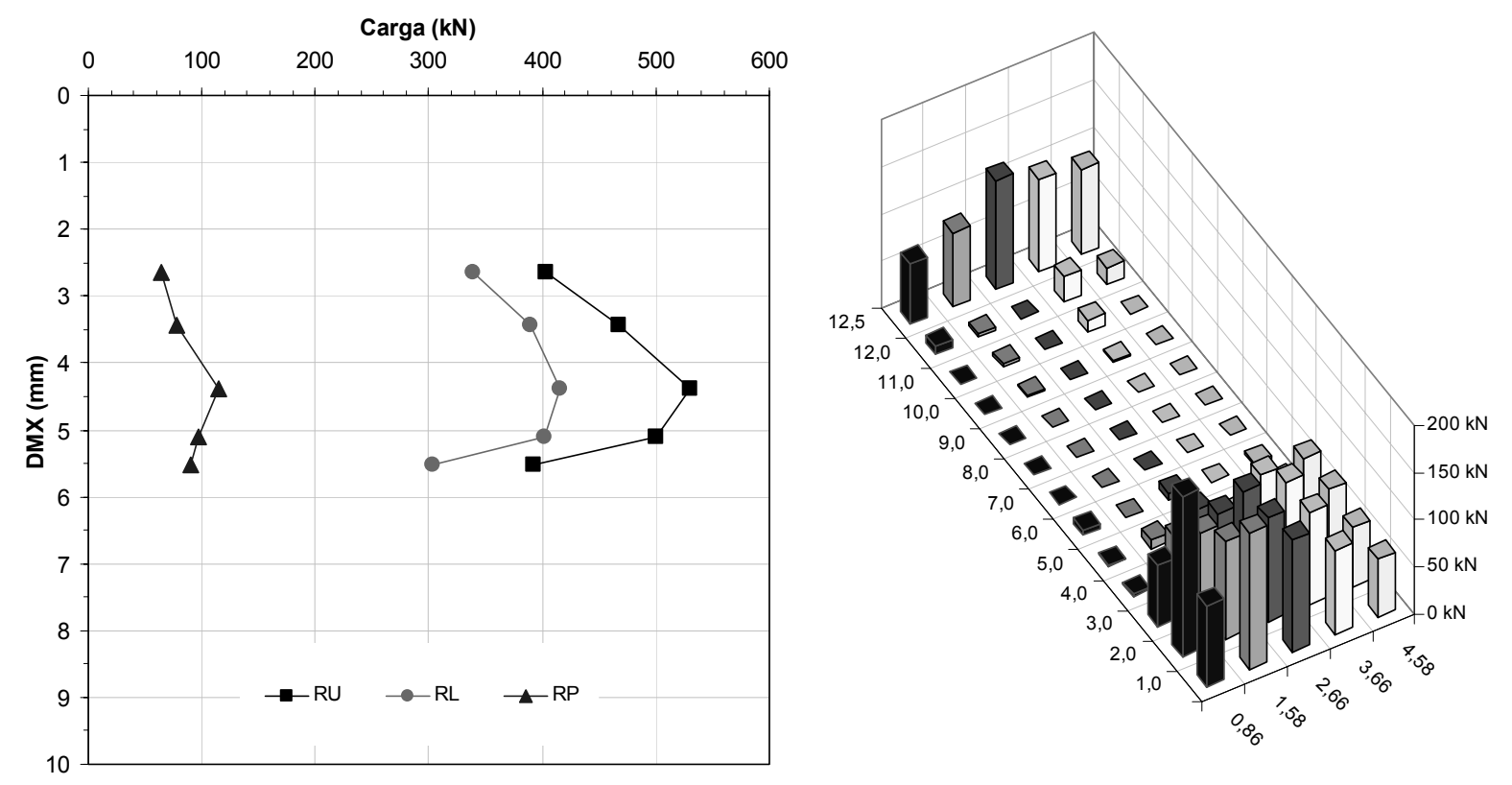

Figura 5.8 - Prova de carga dinâmica na estaca $A 4(0)$ - Reensaio, sem pré-inundação

Os resultados obtidos nos ensaios e reensaios nas estacas originais sem pré-inundação mostraram que a ruptura foi atingida para pequenas $h_{\text {queda }}$ do martelo, variando entre 40 e 80 cm e com EMX variando entre 1,03 e 2,66 kJ. 
A distribuição das resistências se alterou durante a seqüência de golpes dos ensaios - a resistência no topo passou por um pico e diminuiu, transferindo carga para o trecho inferior e a ponta. A resistência obtida nos ensaios destas estacas foi usada como referência para a análise das resistências das demais estacas da pesquisa. A resistência total média obtida nos reensaios mostrou um aumento de $30 \%$ em relação aos ensaios.

\subsection{2- $2^{\mathrm{a}}$ etapa: Estacas do tipo original (0), com inundação}

As estacas da $2^{\text {a }}$ etapa foram ensaiadas com pré-inundação de 48 horas, no dia 16 de novembro de 2002 e, imediatamente após as PCDs iniciais, foram reensaiadas. A pluviosidade nos três dias que as antecederam e no dia dos ensaios está mostrada na Tabela 5.3.

Tabela 5.3 - Pluviosidade no período das PCDs - 2ª etapa (2002)

\begin{tabular}{crccc}
\hline Dia & 13/nov & 14/nov & 15/nov & 16/nov $^{(P C D s)}$ \\
\hline Pluviosidade $(\mathbf{m m})$ & 7,8 & 56,4 & 4,8 & 0,2 \\
\hline
\end{tabular}

As Figuras 5.9 e 5.10 apresentam os resultados dos ensaios executados na estaca B4(O), selecionada desta etapa, na condição de pré-inundação.
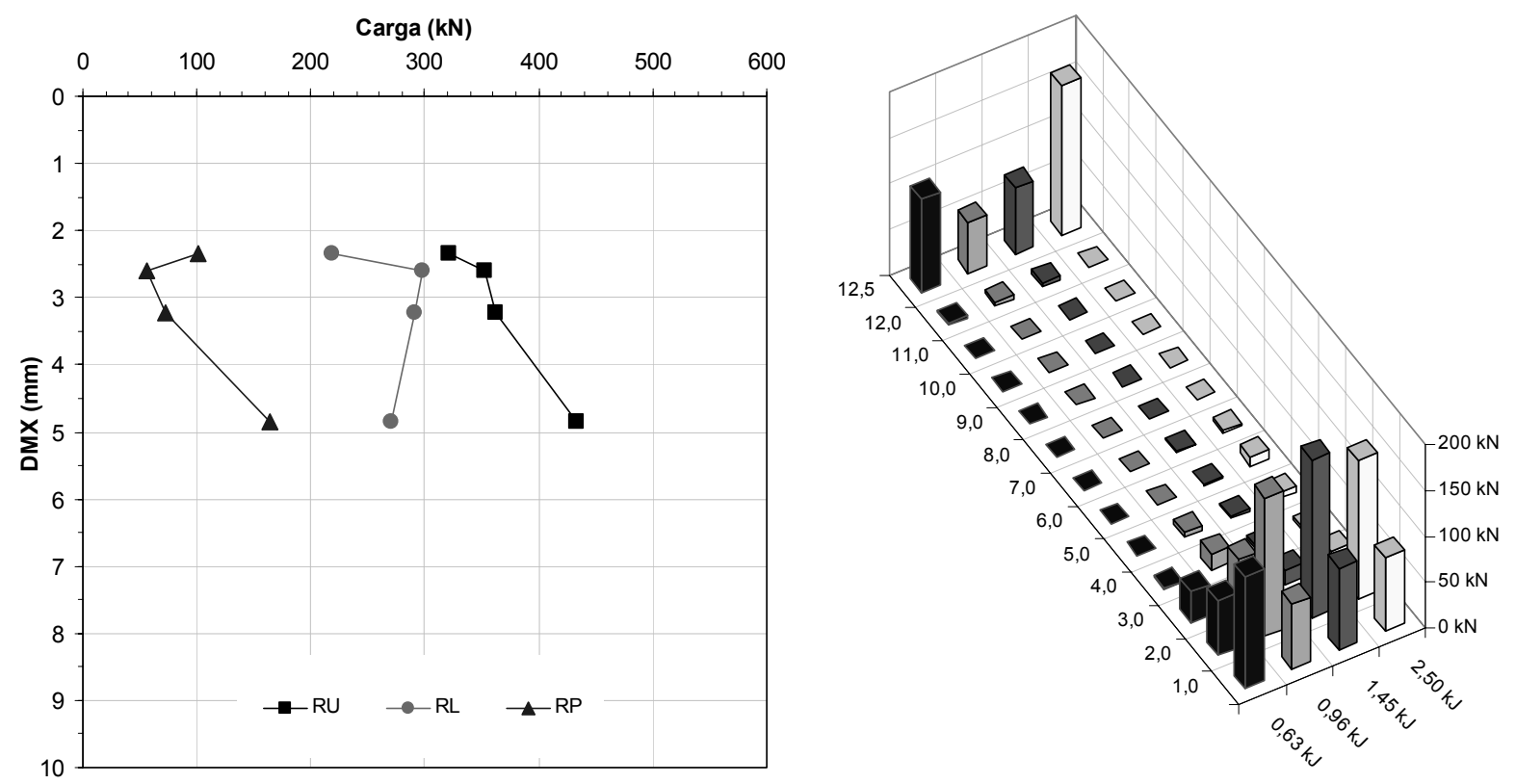

Figura 5.9 - Prova de carga dinâmica na estaca B4(0) - Ensaio, com pré-inundação 

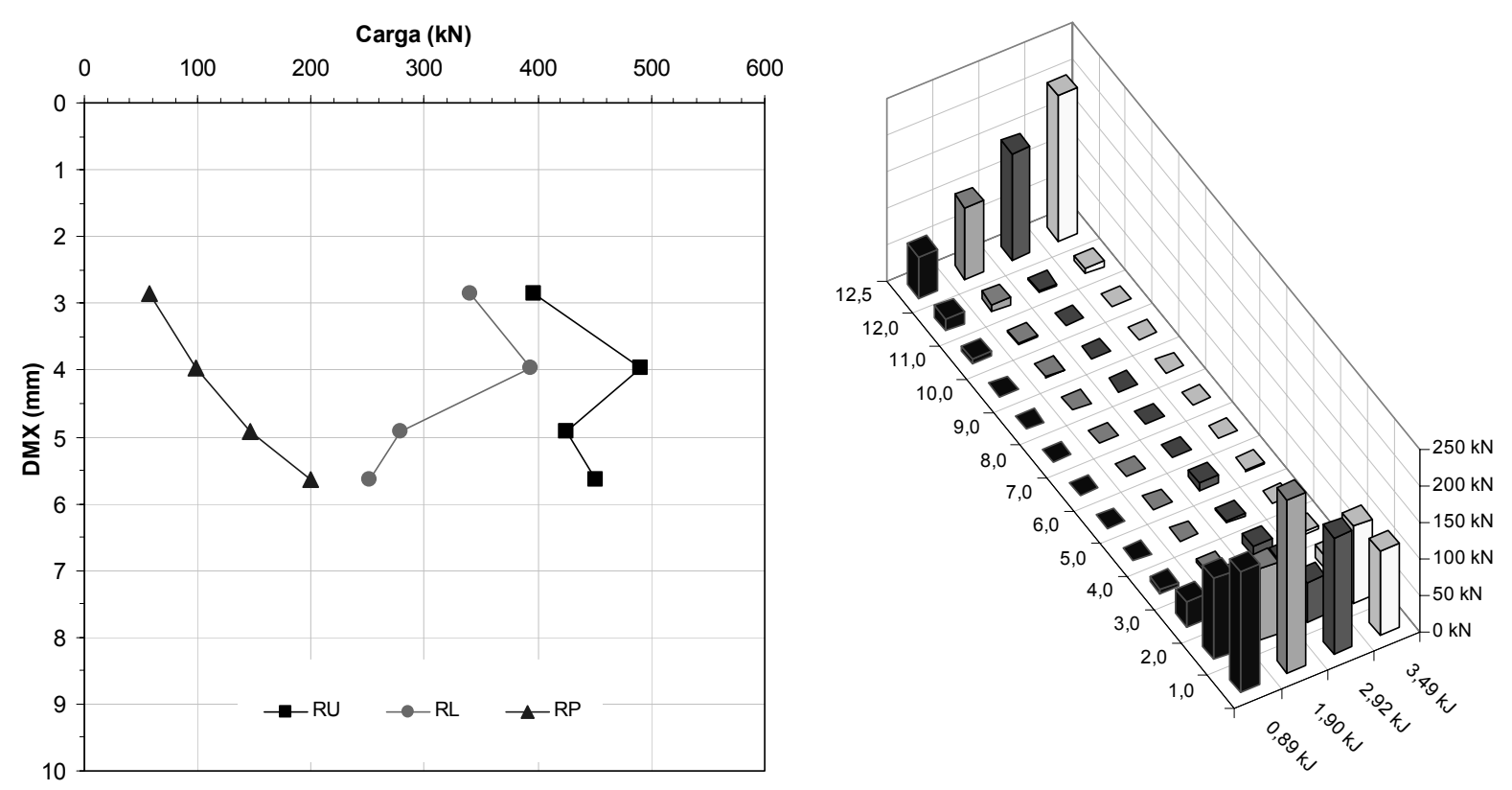

Figura 5.10 - Prova de carga dinâmica na estaca B4(0) - Reensaio, com pré-inundação

A distribuição de carga ao longo da estaca B4(O) também apresentou comportamento similar ao observado nas estacas $\mathrm{A} 1(\mathrm{O})$ e $\mathrm{A} 4(\mathrm{O})$. A ruptura também foi atingida para pequenas $\mathrm{h}_{\text {queda }}$ do martelo, iguais a $60 \mathrm{~cm}$ e com EMX variando entre 1,45 kJ (ensaio) e 1,90 kJ (reensaio). A resistência total também apresentou um aumento de $30 \%$ em relação às estacas de referência $(\mathrm{A} 1(\mathrm{O})$ e $\mathrm{A} 4(\mathrm{O}))$

\subsection{3- 5a etapa: Estacas dos tipos limpa com caçamba (LC), solo melhorado (SM) e "bucha de Strauss" (BS), sem inundação}

As estacas da $5^{\text {a }}$ etapa foram ensaiadas, sem pré-inundação, nos dias 18 e 19 de fevereiro de 2005 e, imediatamente após as PCDs iniciais, foram reensaiadas. Os resultados estão A pluviosidade nos dois dias que as antecederam e nos dias dos ensaios está mostrada na Tabela 5.4 .

Tabela 5.4 - Pluviosidade no período das PCDs - 5ª etapa (2005)

\begin{tabular}{|c|c|c|c|c|}
\hline Dia & $16 / f e v$ & $17 / f e v$ & $18 / \mathrm{fev}^{(P C D s)}$ & $19 / \mathrm{fev}^{(P C D s)}$ \\
\hline Pluviosidade ( $\mathrm{mm}$ ) & 0,0 & 0,0 & 0,0 & 16,8 \\
\hline
\end{tabular}


Foram, também, determinados os teores de umidade do solo em profundidade, a partir de amostras coletadas a trado. Os resultados obtidos estão na Tabela 5.5.

Tabela 5.5 - Teores de umidade determinados em 19/fev/2005 - PCDs - 5ª etapa (2005)

\begin{tabular}{cccccccc}
\hline Profundidade $(\boldsymbol{m})$ & $\mathbf{1 , 0}$ & $\mathbf{2 , 0}$ & $\mathbf{3 , 0}$ & $\mathbf{4 , 0}$ & $\mathbf{5 , 0}$ & $\mathbf{6 , 0}$ & $\mathbf{6 , 8}$ \\
\hline $\boldsymbol{w}(\%)$ & 34,5 & 36,4 & 34,7 & 33,9 & 34,2 & 33,9 & 34,0 \\
\hline
\end{tabular}

As Figuras 5.11 a 5.28 apresentam os resultados dos ensaios executados nas estacas B8(LC), B10(LC), C8(LC), A8(SM), B9(SM), C10(SM), A9(BS), A10(BS) e C9(BS), sem préinundação.
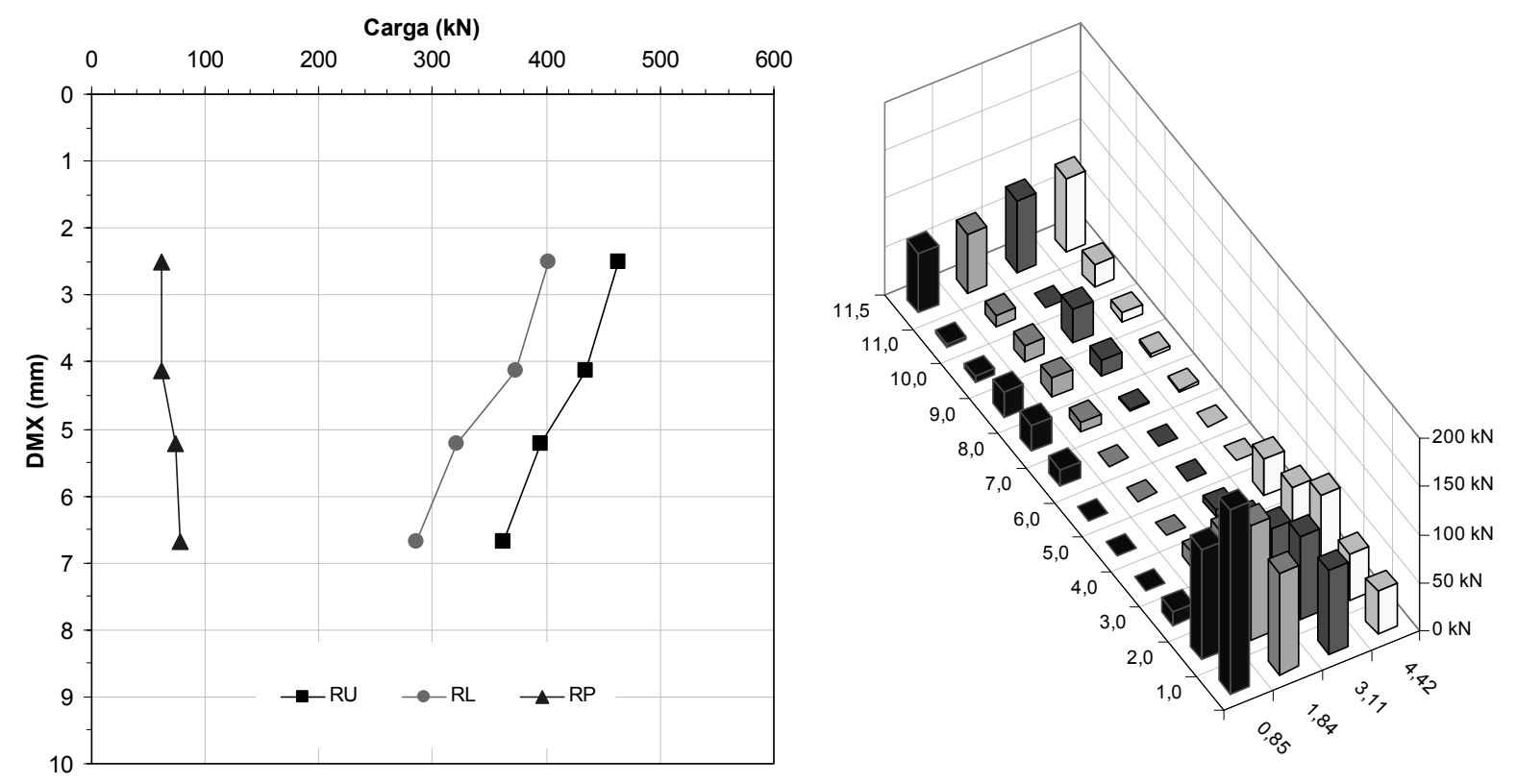

Figura 5.11 - Prova de carga dinâmica na estaca B8(LC) - Ensaio, sem pré-inundação 

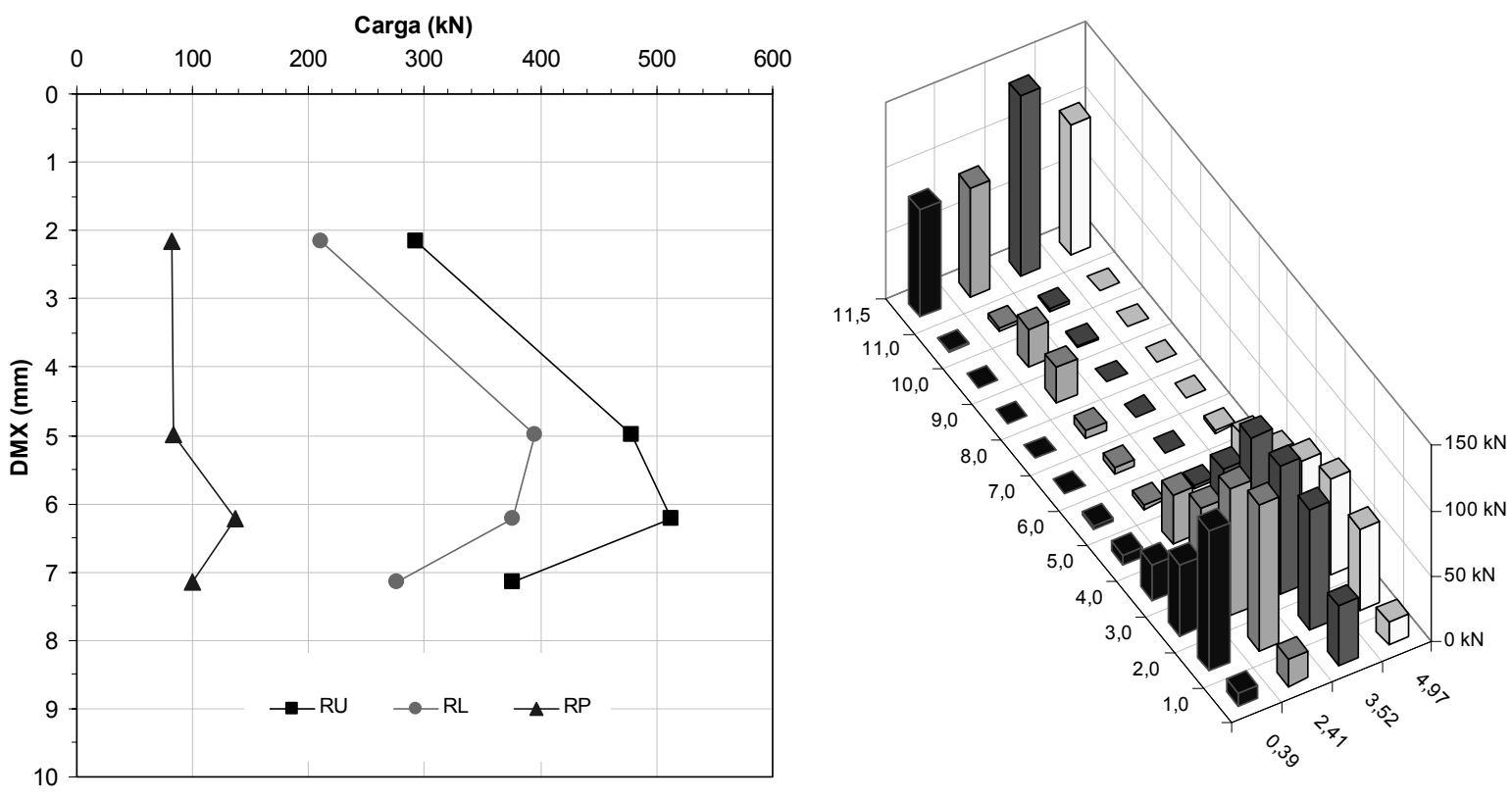

Figura 5.12 - Prova de carga dinâmica na estaca B8(LC) - Reensaio, sem pré-inundação
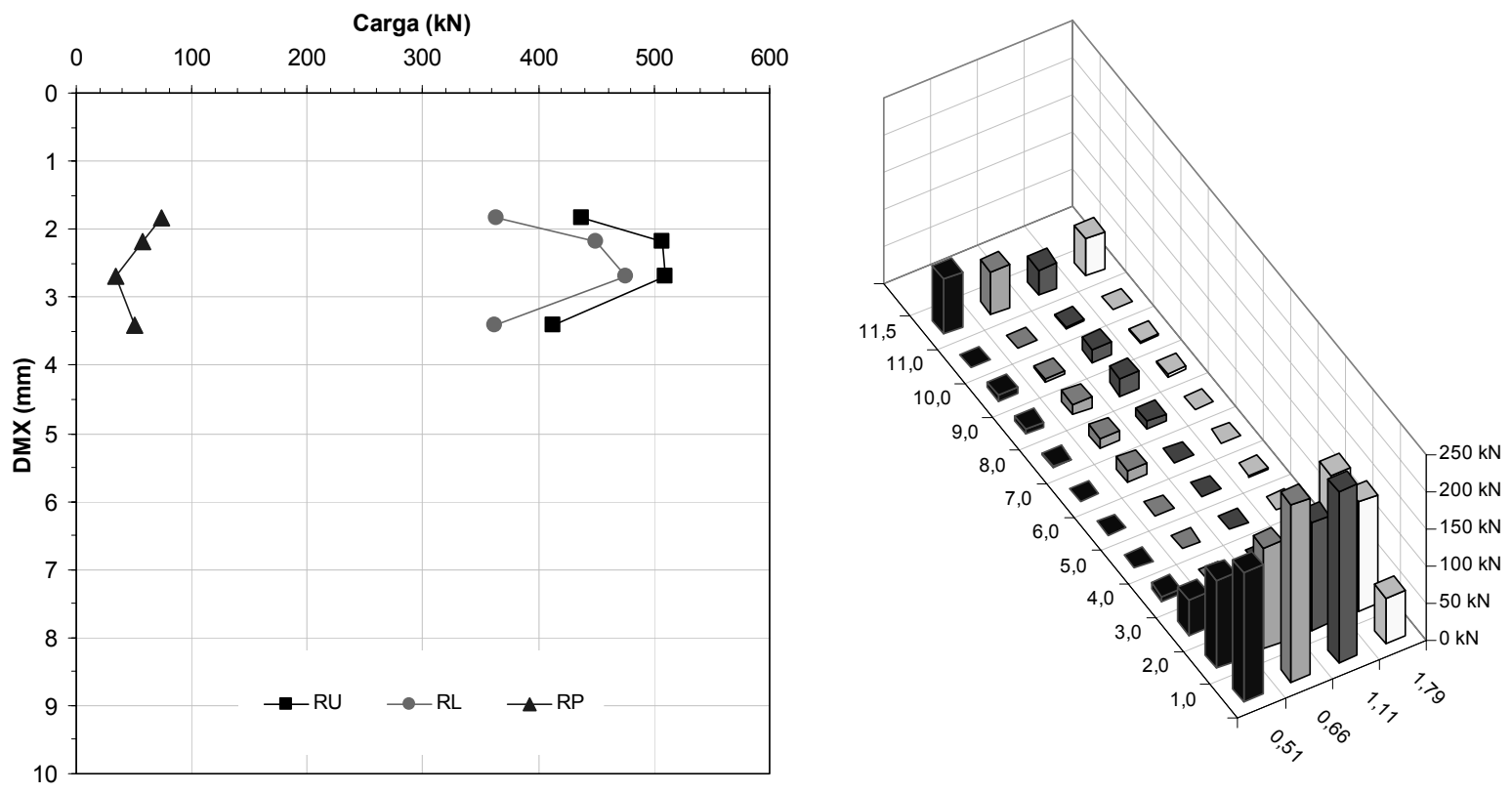

Figura 5.13 - Prova de carga dinâmica na estaca B10(LC) - Ensaio, sem pré-inundação 

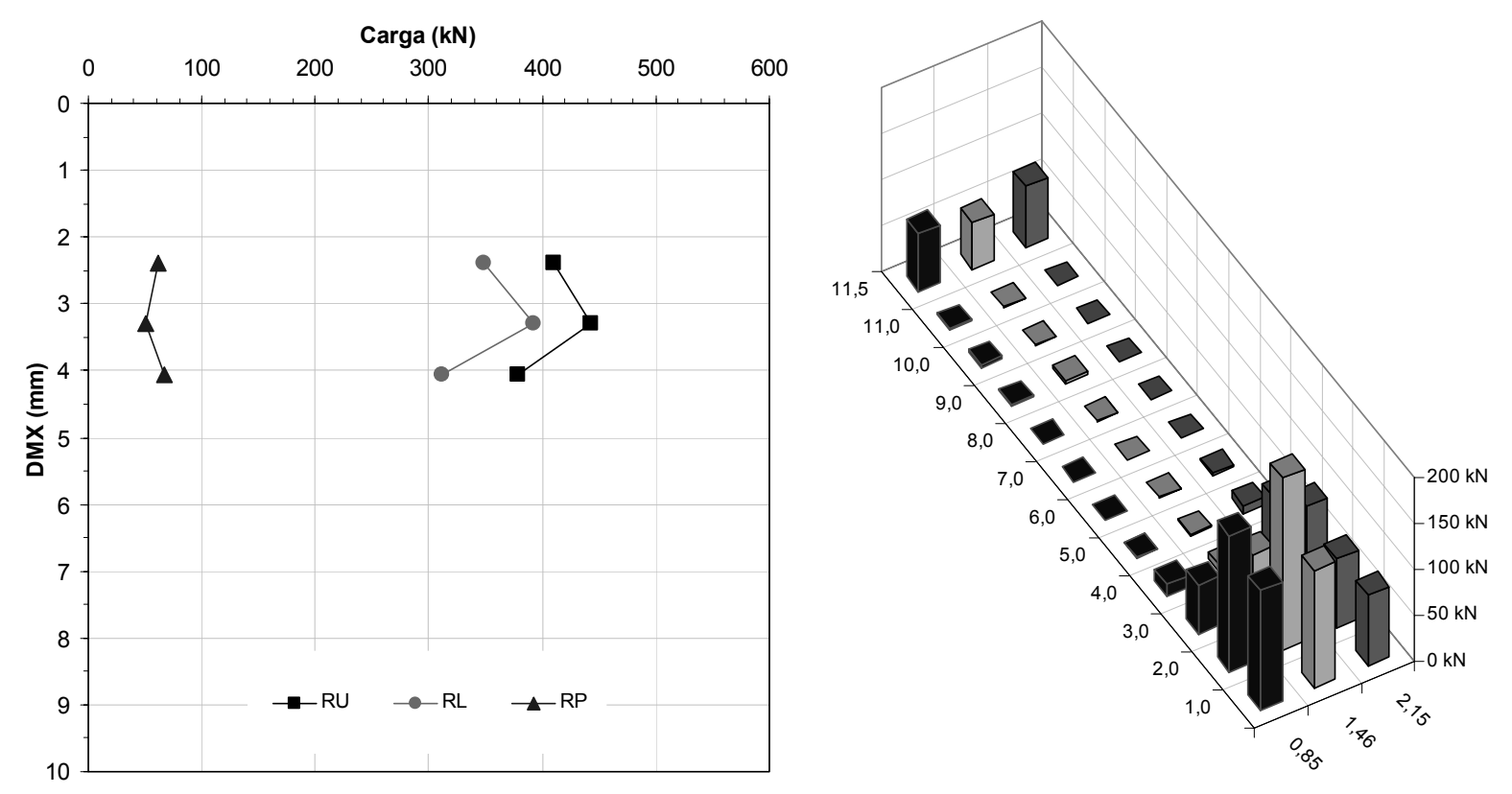

Figura 5.14 - Prova de carga dinâmica na estaca B10(LC) - Reensaio, sem pré-inundação
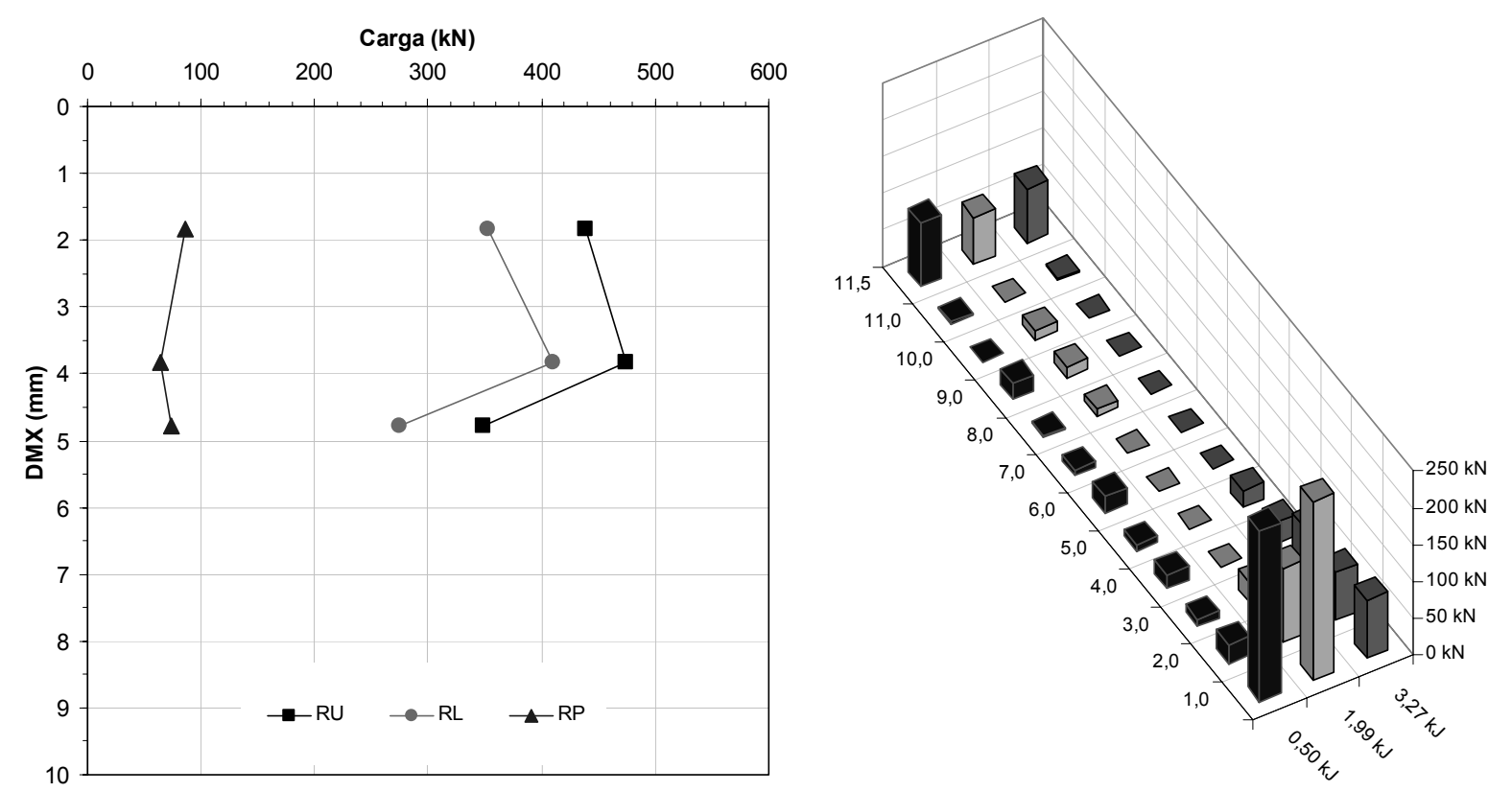

Figura 5.15 - Prova de carga dinâmica na estaca C8(LC) - Ensaio, sem pré-inundação 

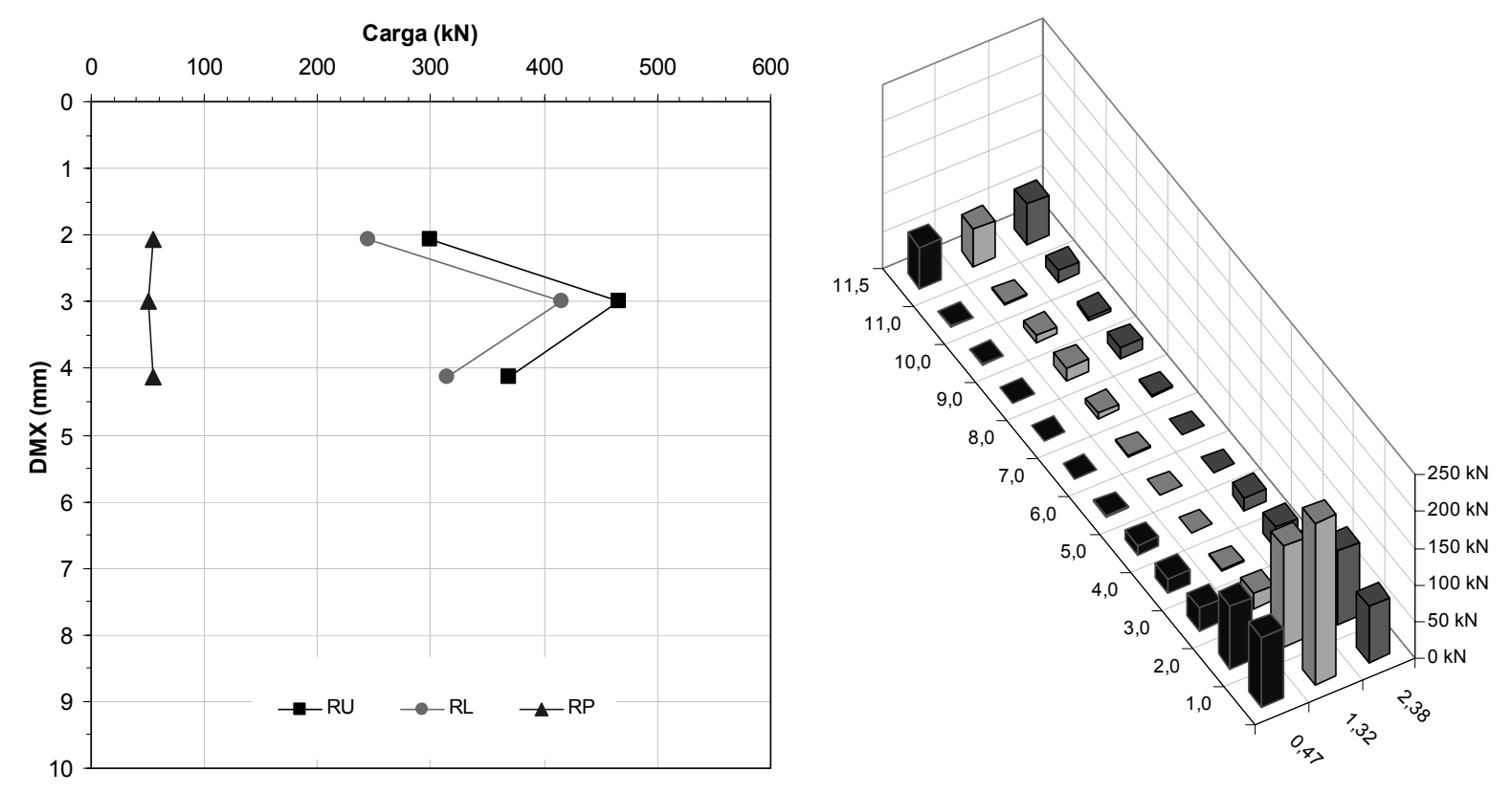

Figura 5.16 - Prova de carga dinâmica na estaca C8(LC) - Reensaio, sem pré-inundação
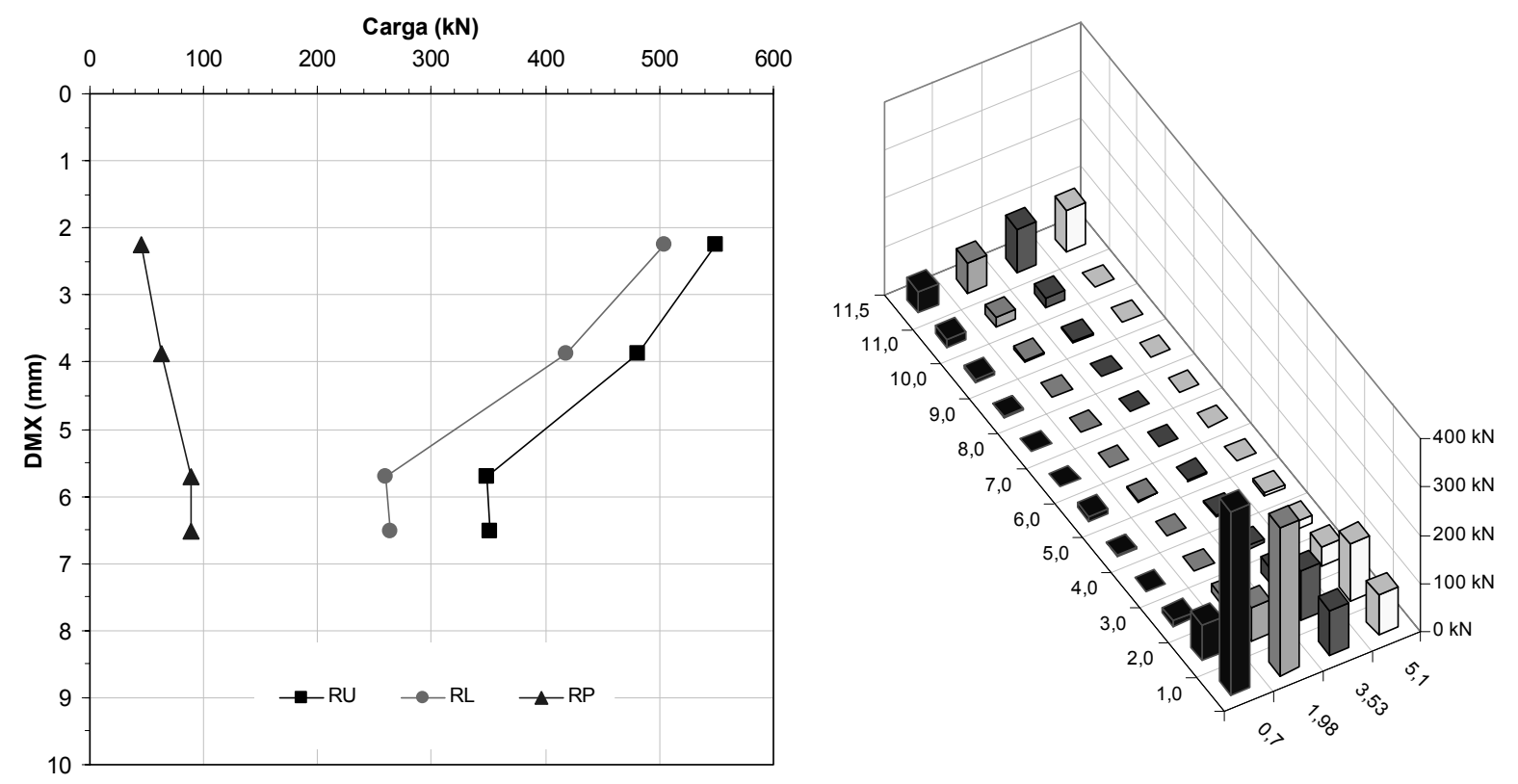

Figura 5.17 - Prova de carga dinâmica na estaca A8(SM) - Ensaio, sem pré-inundação 

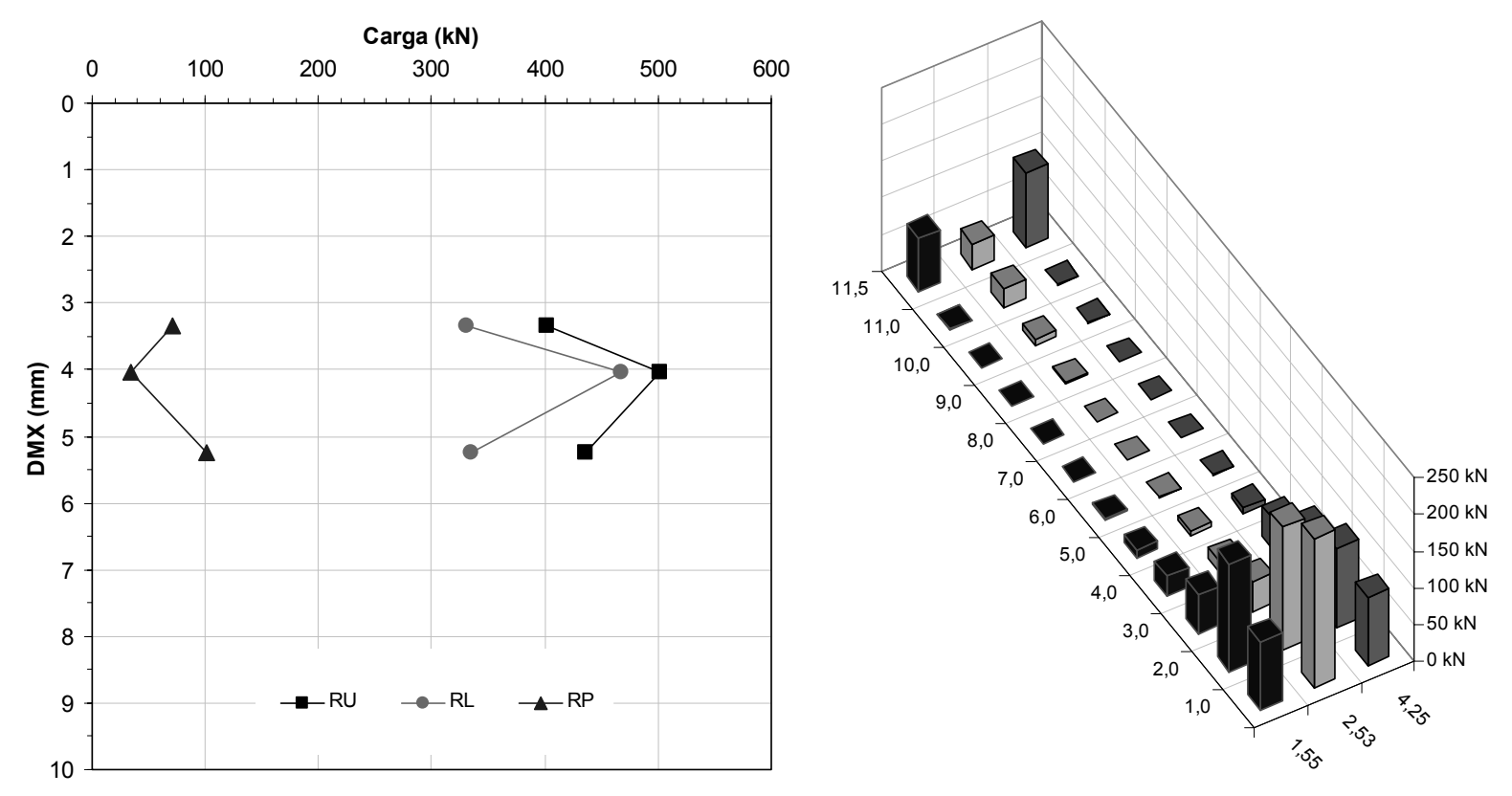

Figura 5.18 - Prova de carga dinâmica na estaca A8(SM) - Reensaio, sem pré-inundação
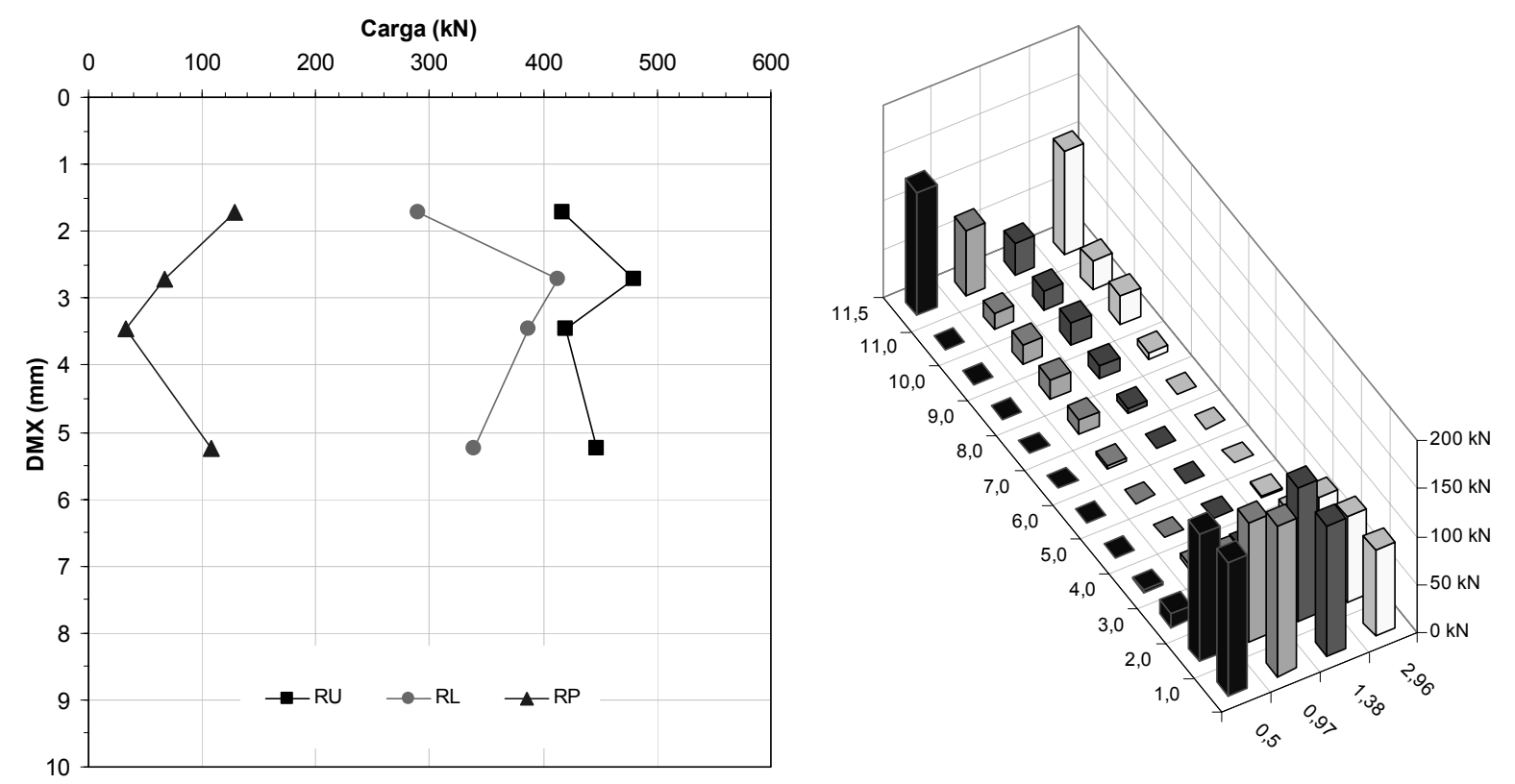

Figura 5.19 - Prova de carga dinâmica na estaca B9(SM) - Ensaio, sem pré-inundação 

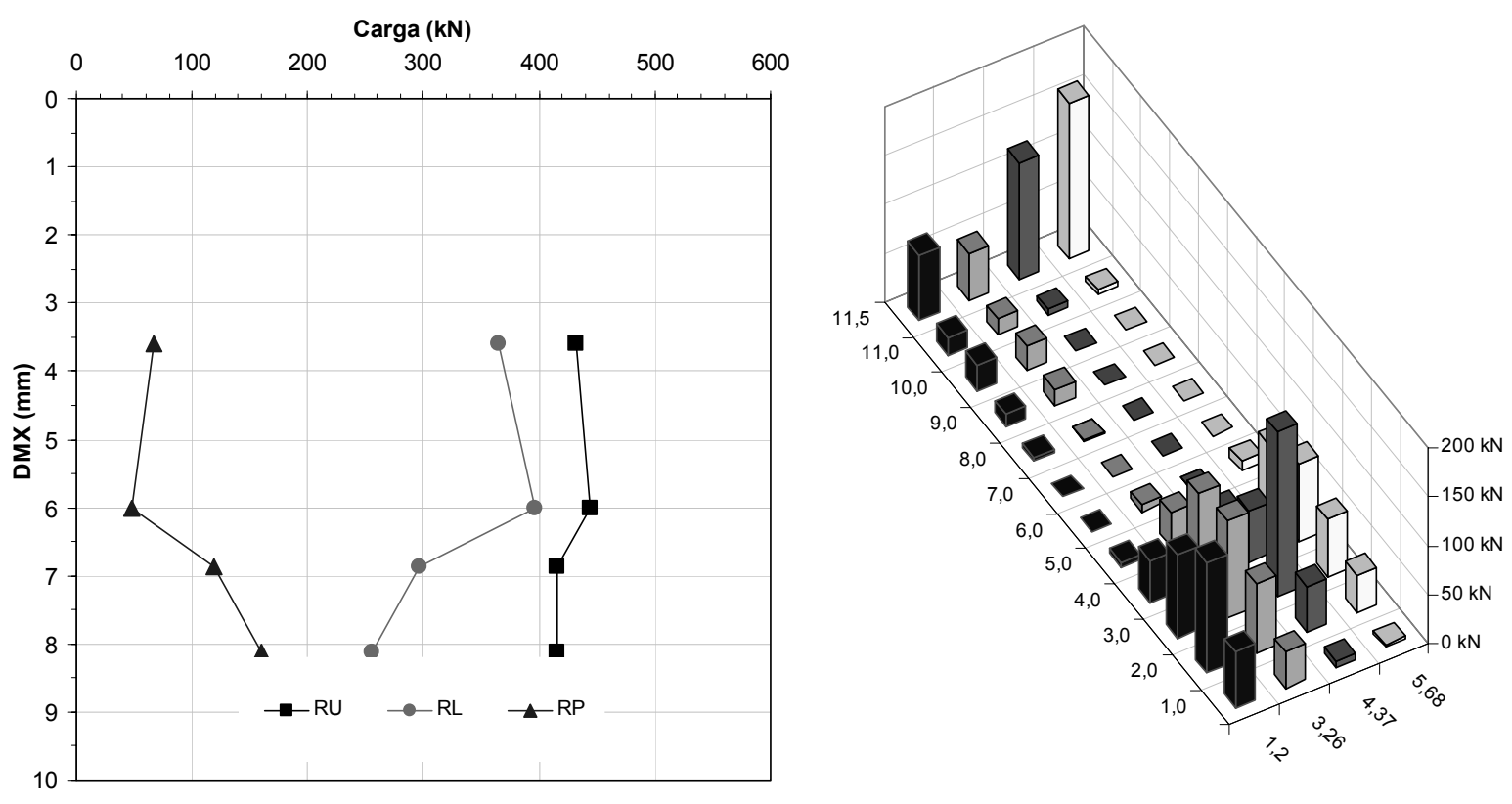

Figura 5.20 - Prova de carga dinâmica na estaca B9(SM) - Reensaio, sem pré-inundação
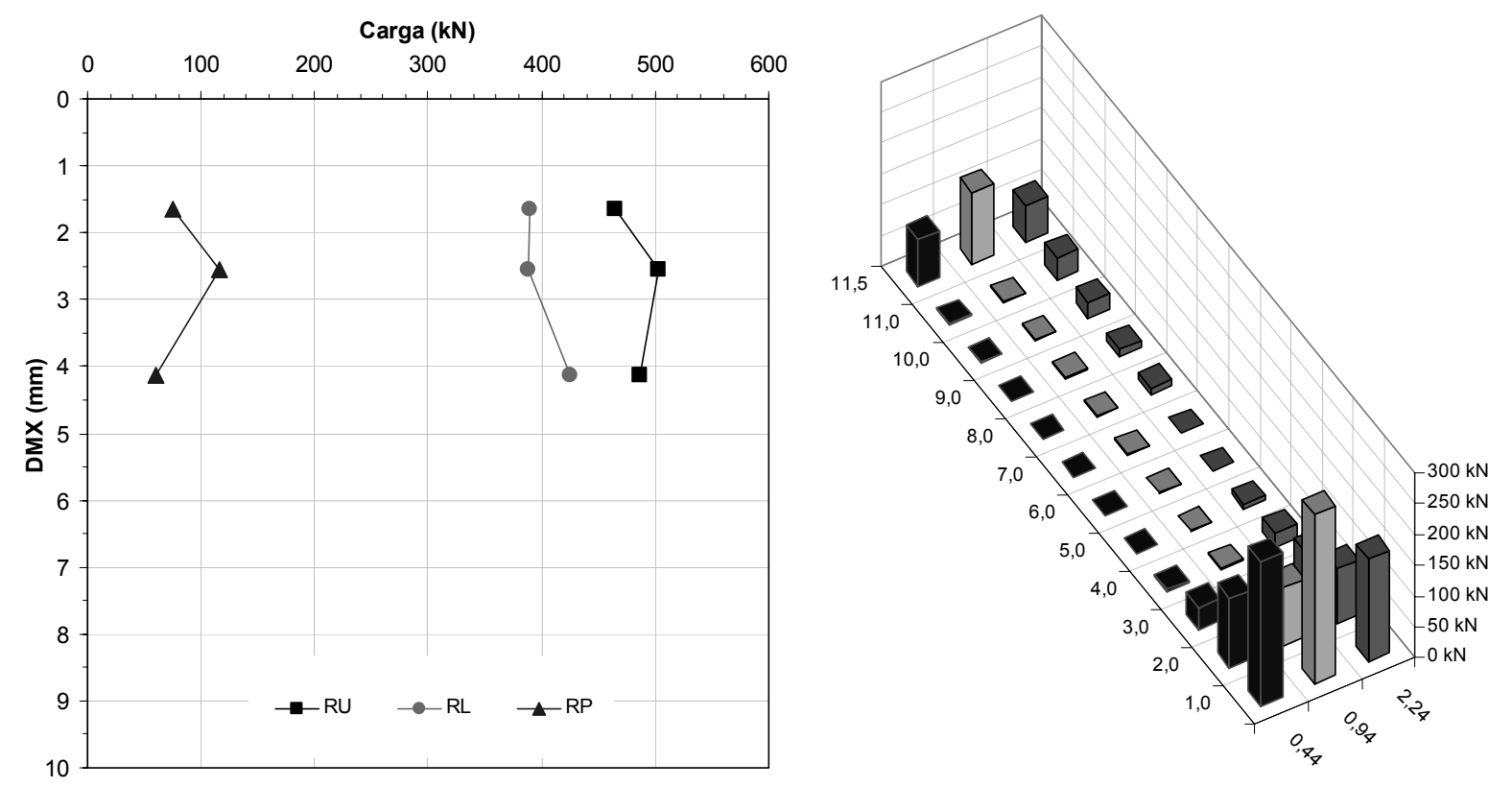

Figura 5.21 - Prova de carga dinâmica na estaca C10(SM) - Ensaio, sem pré-inundação 

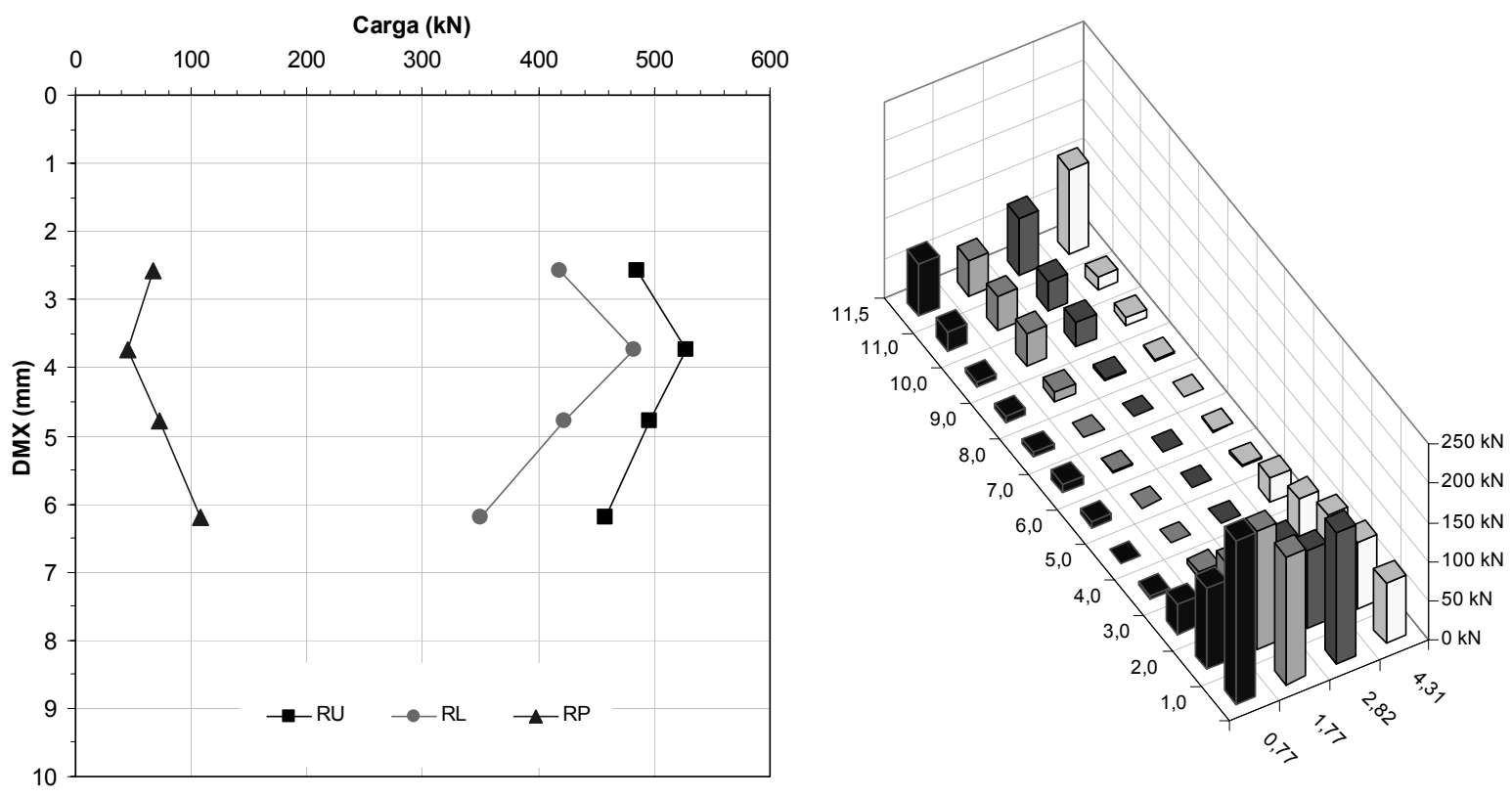

Figura 5.22 - Prova de carga dinâmica na estaca C10(SM) - Reensaio, sem pré-inundação
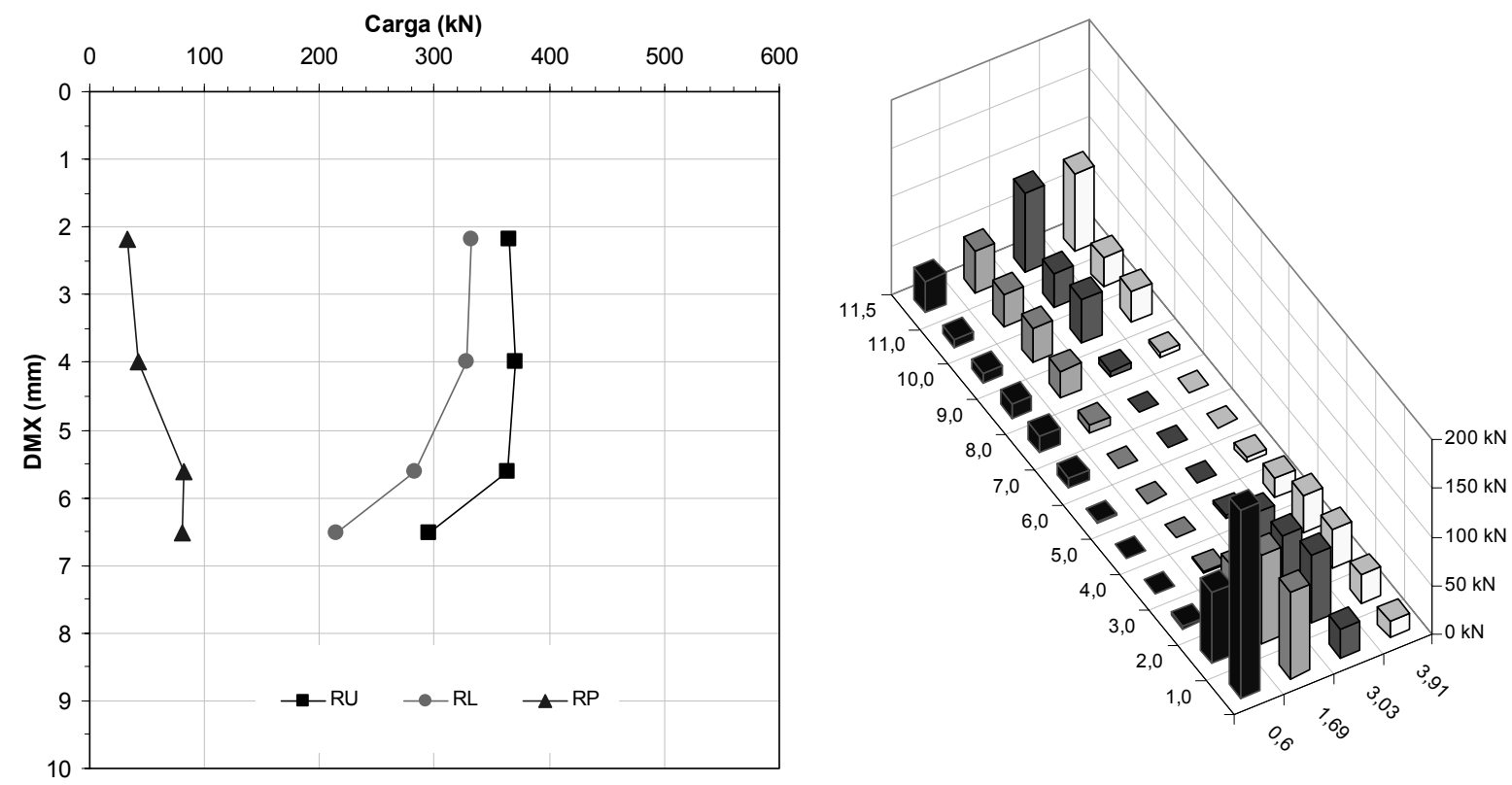

Figura 5.23 - Prova de carga dinâmica na estaca A9(BS) - Ensaio, sem pré-inundação 

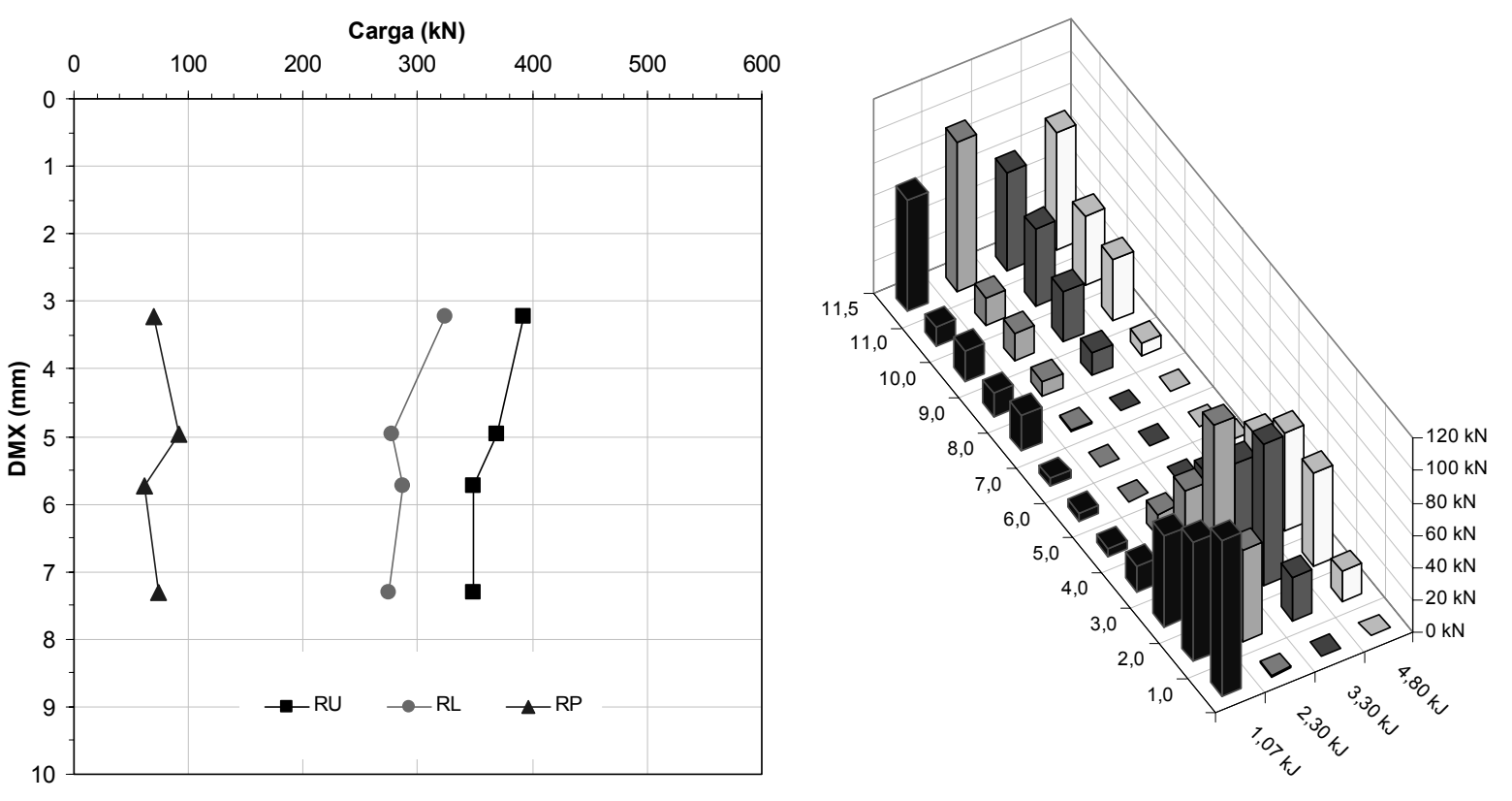

Figura 5.24 - Prova de carga dinâmica na estaca A9(BS) - Reensaio, sem pré-inundação
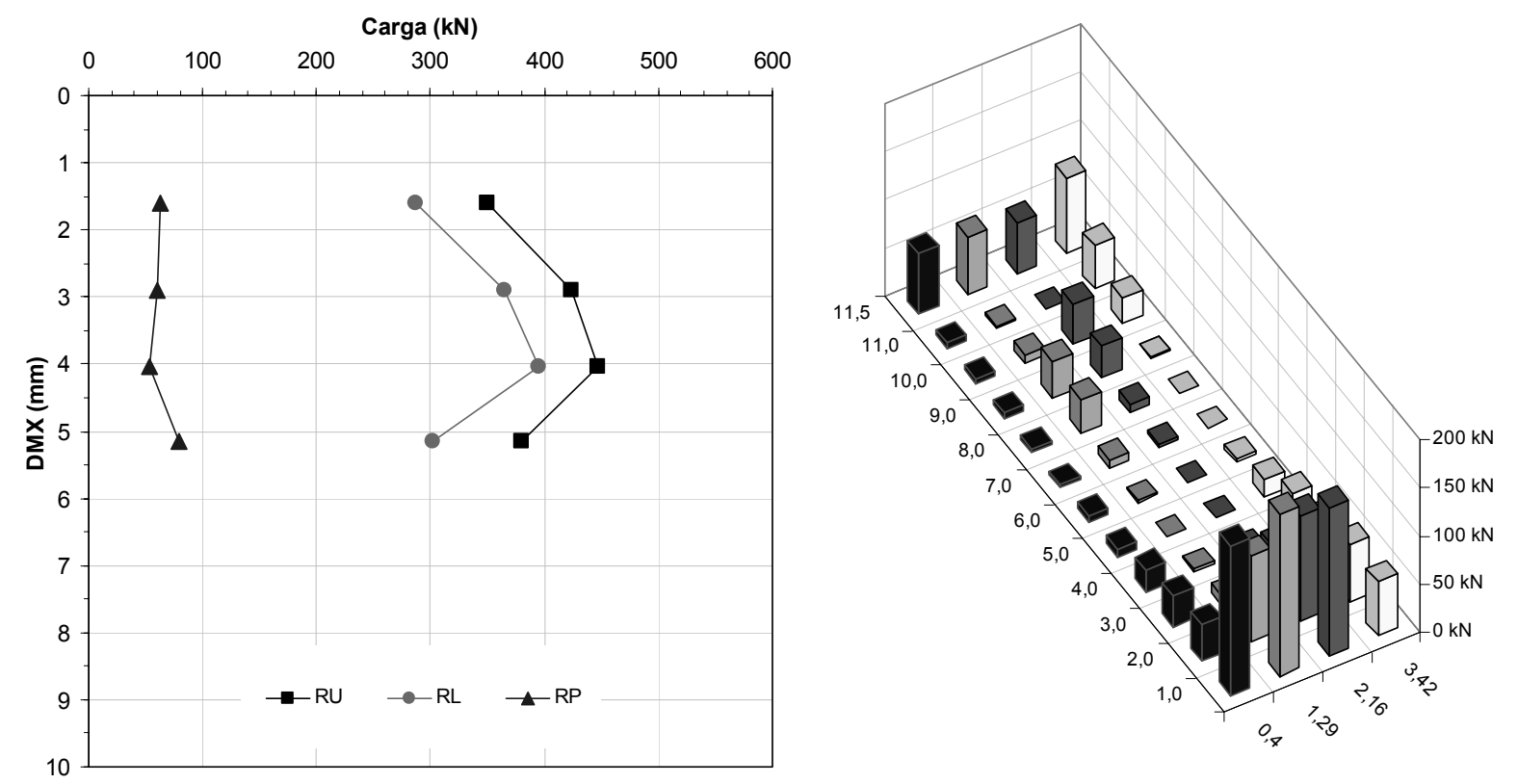

Figura 5.25 - Prova de carga dinâmica na estaca A10(BS) - Ensaio, sem pré-inundação 

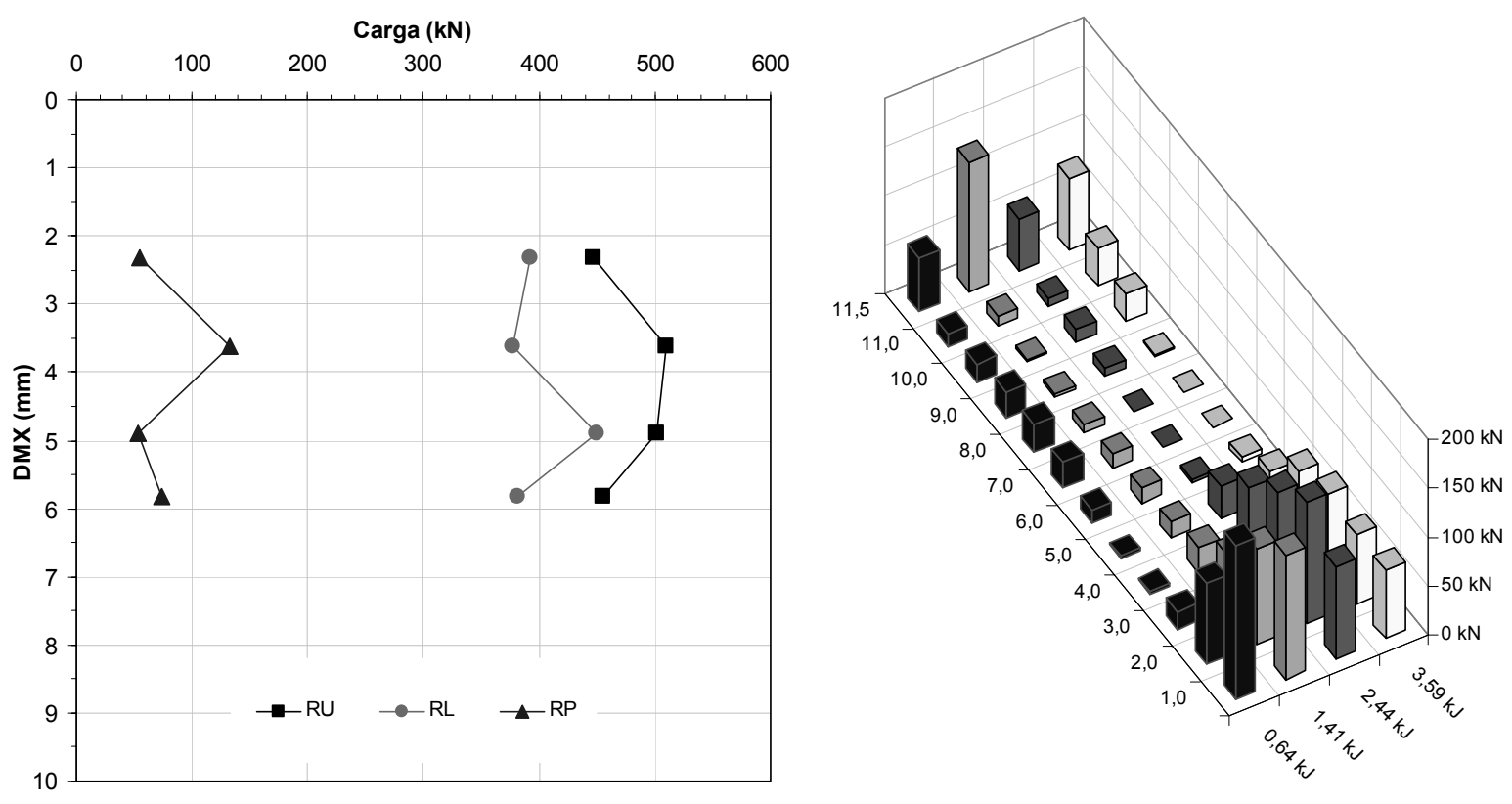

Figura 5.26 - Prova de carga dinâmica na estaca A10(BS) - Reensaio, sem pré-inundação
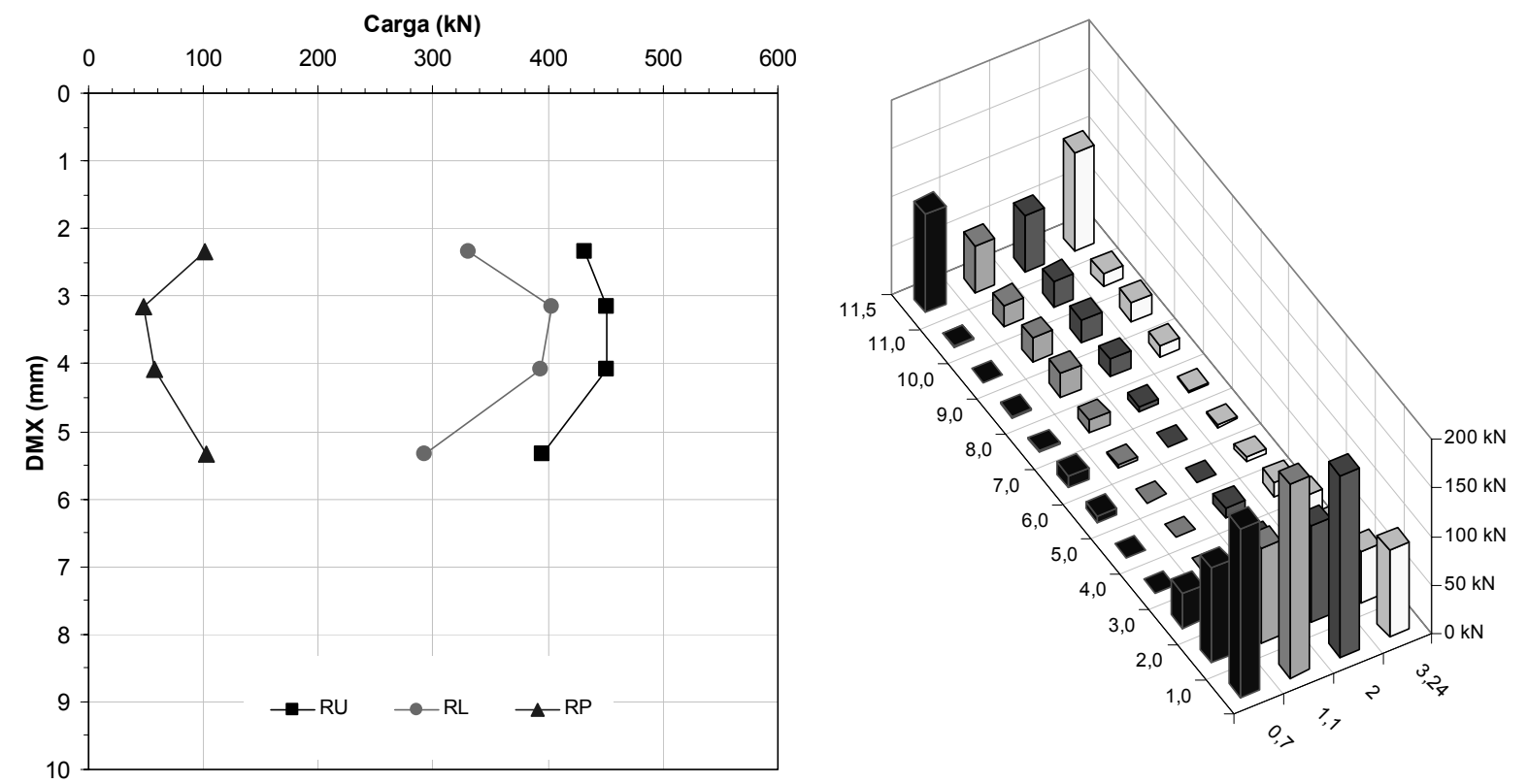

Figura 5.27 - Prova de carga dinâmica na estaca C9(BS) - Ensaio, sem pré-inundação 

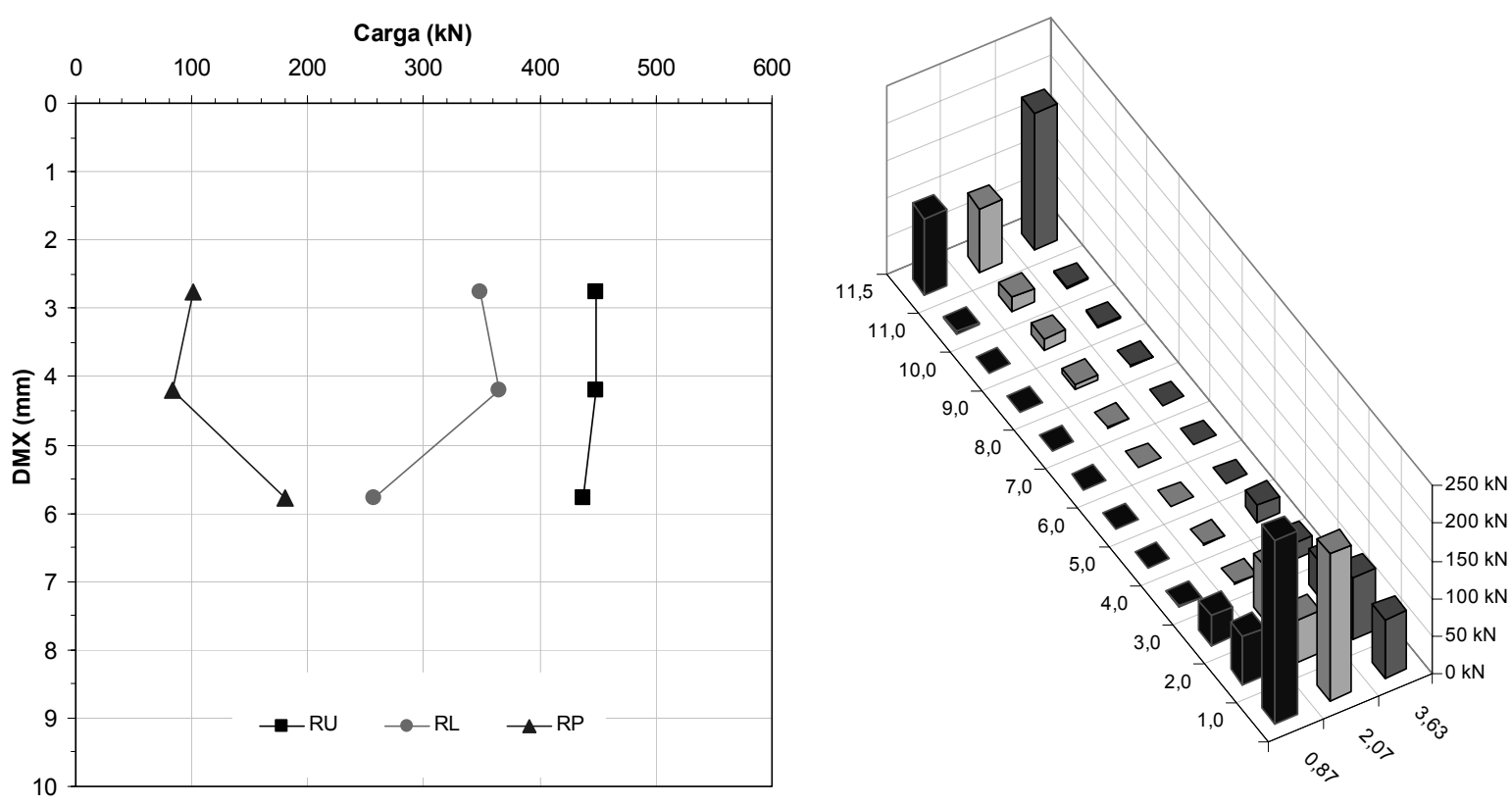

Figura 5.28 - Prova de carga dinâmica na estaca C9(BS) - Reensaio, sem pré-inundação

A distribuição de carga ao longo das estacas com ponta modificada também apresentou comportamento similar ao observado nas estacas de referência. A ruptura também foi atingida para pequenas $\mathrm{h}_{\text {queda }}$ do martelo, variando entre 40 e $80 \mathrm{~cm}$ e com EMX variando entre 0,70 e 3,52 kJ. A resistência total média destas estacas também apresentou aumento em relação às estacas de referência, variando entre $12 \%$ (BS) e $36 \%$ (SM).

\subsection{4- 6⿳a etapa: Estacas do tipo base alargada (BA), sem e com pré-inundação}

Imediatamente após o preparo da ponta das estacas da $6^{\mathrm{a}}$ etapa pelo TI-01, cada qual foi inspecionada com o uso da câmera de vídeo e, em seguida, as estacas foram concretadas. Um exemplo de imagem está ilustrado na Figura 5.29.
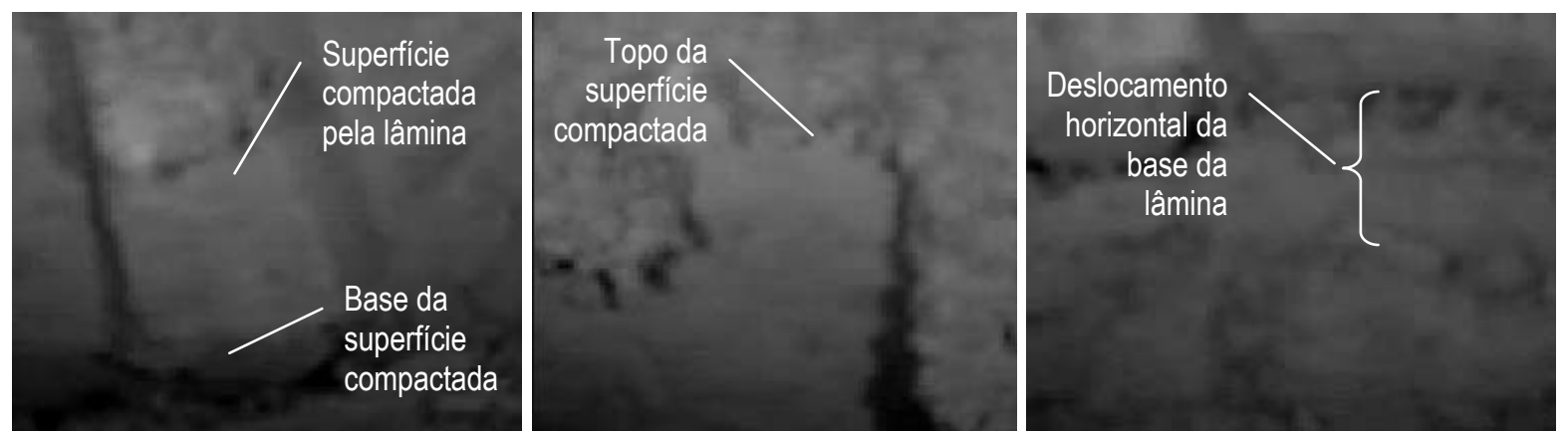

Figura 5.29- Aspectos do preparo da ponta da estaca A11(BA) 
A pluviosidade nos dois dias anteriores e no dia dos ensaios está mostrada na Tabela 5.6.

Tabela 5.6 - Pluviosidade no período das PCDs - 6 etapa (2006)

\begin{tabular}{cccc}
\hline Dia & 05/mar & 06/mar & 07/mar \\
\hline Pluviosidade $(\mathbf{m m})$ & 0,3 & 0,4 & 0,0 \\
\hline
\end{tabular}

As estacas A11(BA), A12(BA) e B11(BA) foram ensaiadas sem pré-inundação e a estaca B19(BA) foi ensaiada no mesmo dia que as demais, com a pré-inundação de 48 horas. Imediatamente após as respectivas PCDs iniciais, cada uma das estacas foi reensaiada. As Figuras 5.30 a 5.37 apresentam os resultados dos ensaios executados nestas estacas.
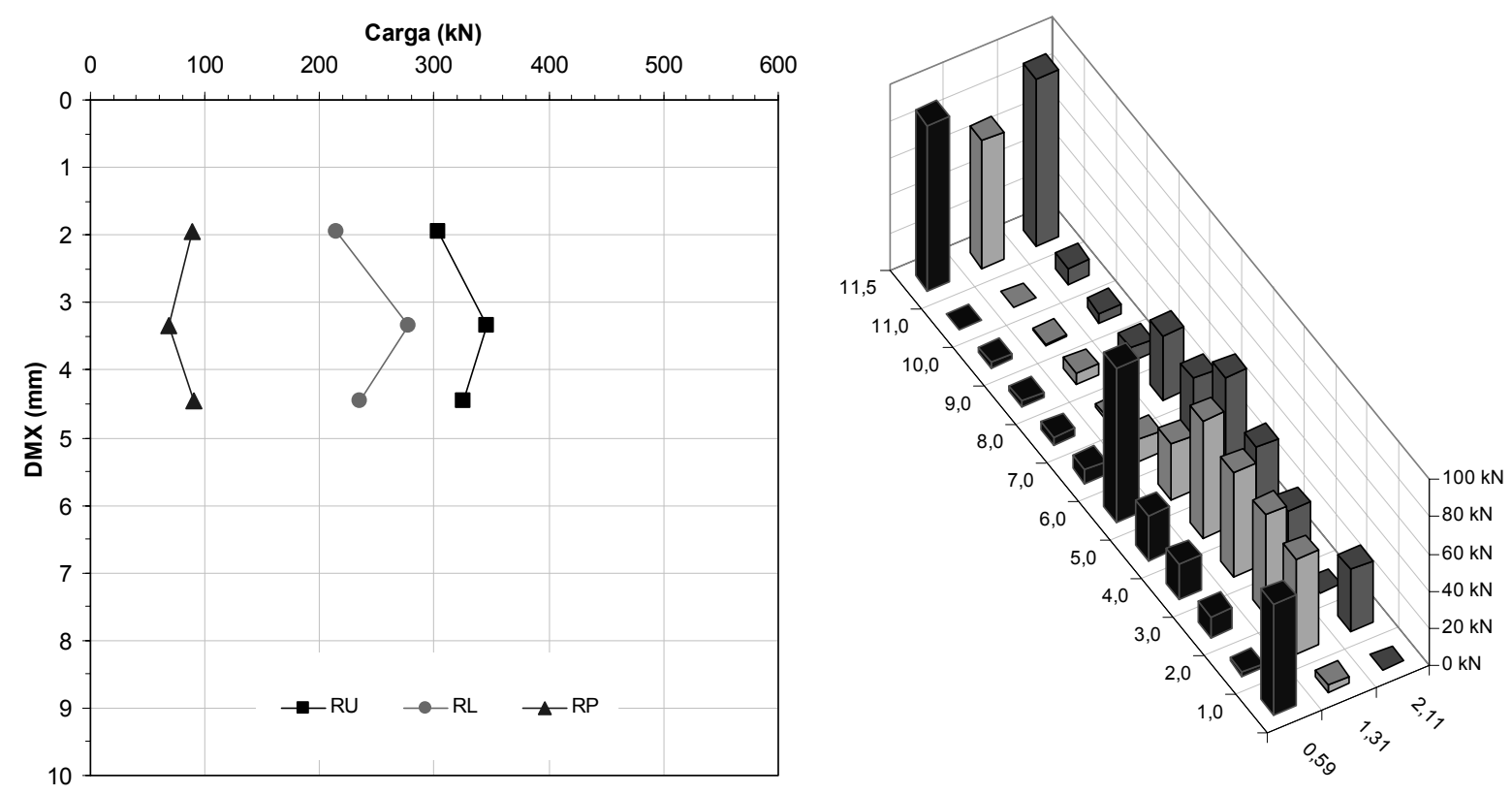

Figura 5.30 - Prova de carga dinâmica na estaca A11(BA) - Ensaio, sem pré-inundação 

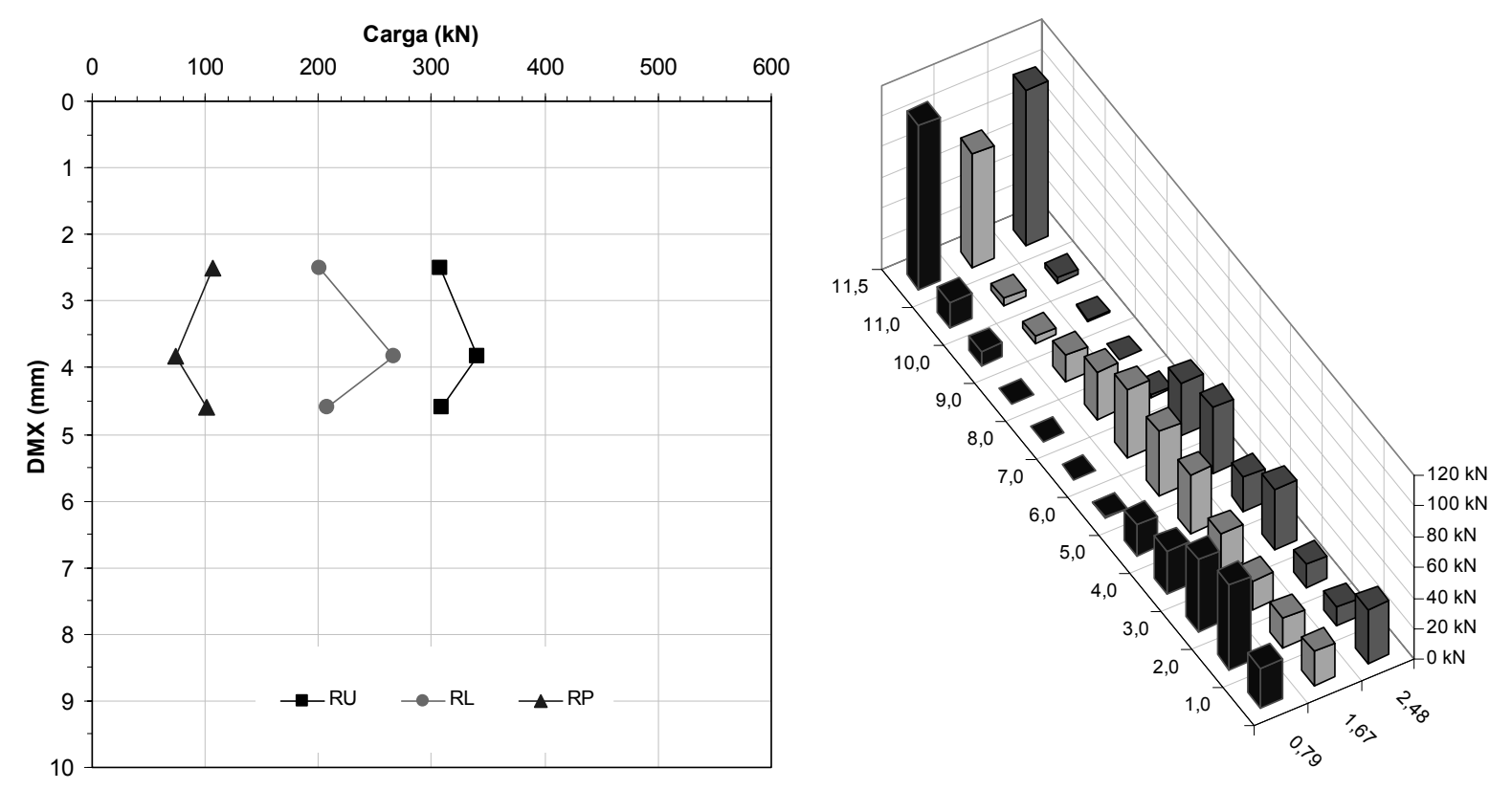

Figura 5.31 - Prova de carga dinâmica na estaca A11(BA) - Reensaio, sem pré-inundação
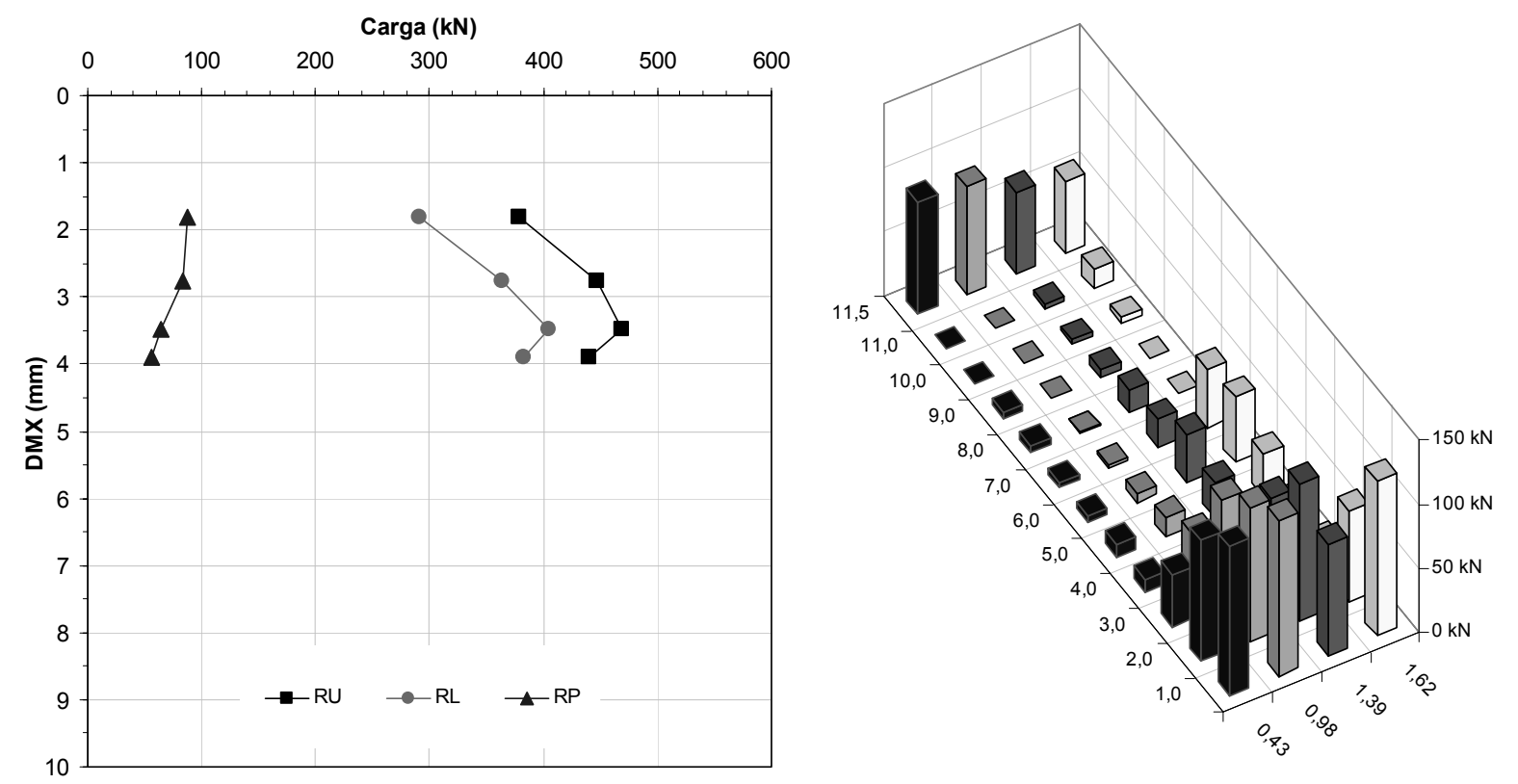

Figura 5.32 - Prova de carga dinâmica na estaca A12(BA) - Ensaio, sem pré-inundação 

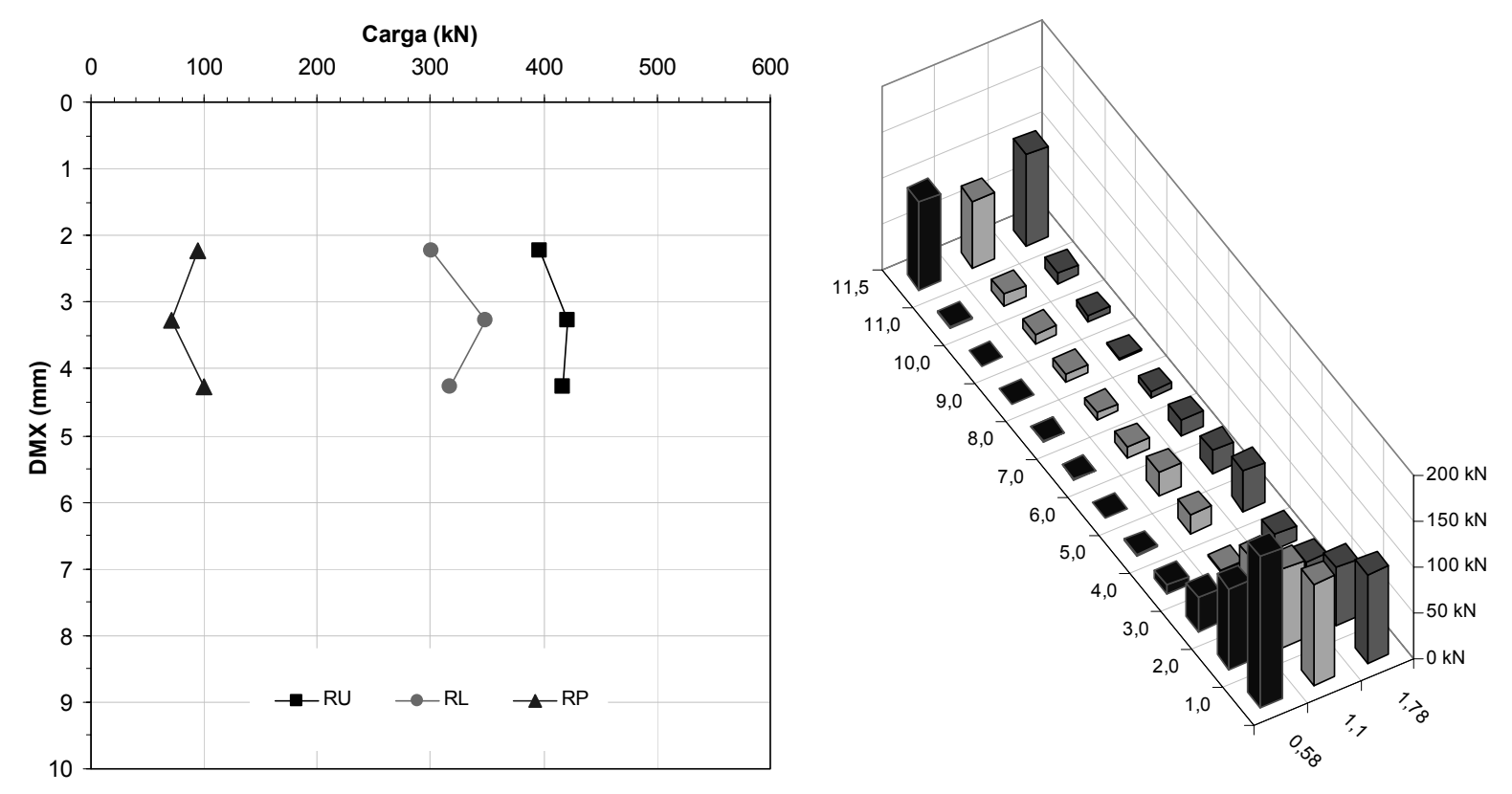

Figura 5.33 - Prova de carga dinâmica na estaca A12(BA) - Reensaio, sem pré-inundação
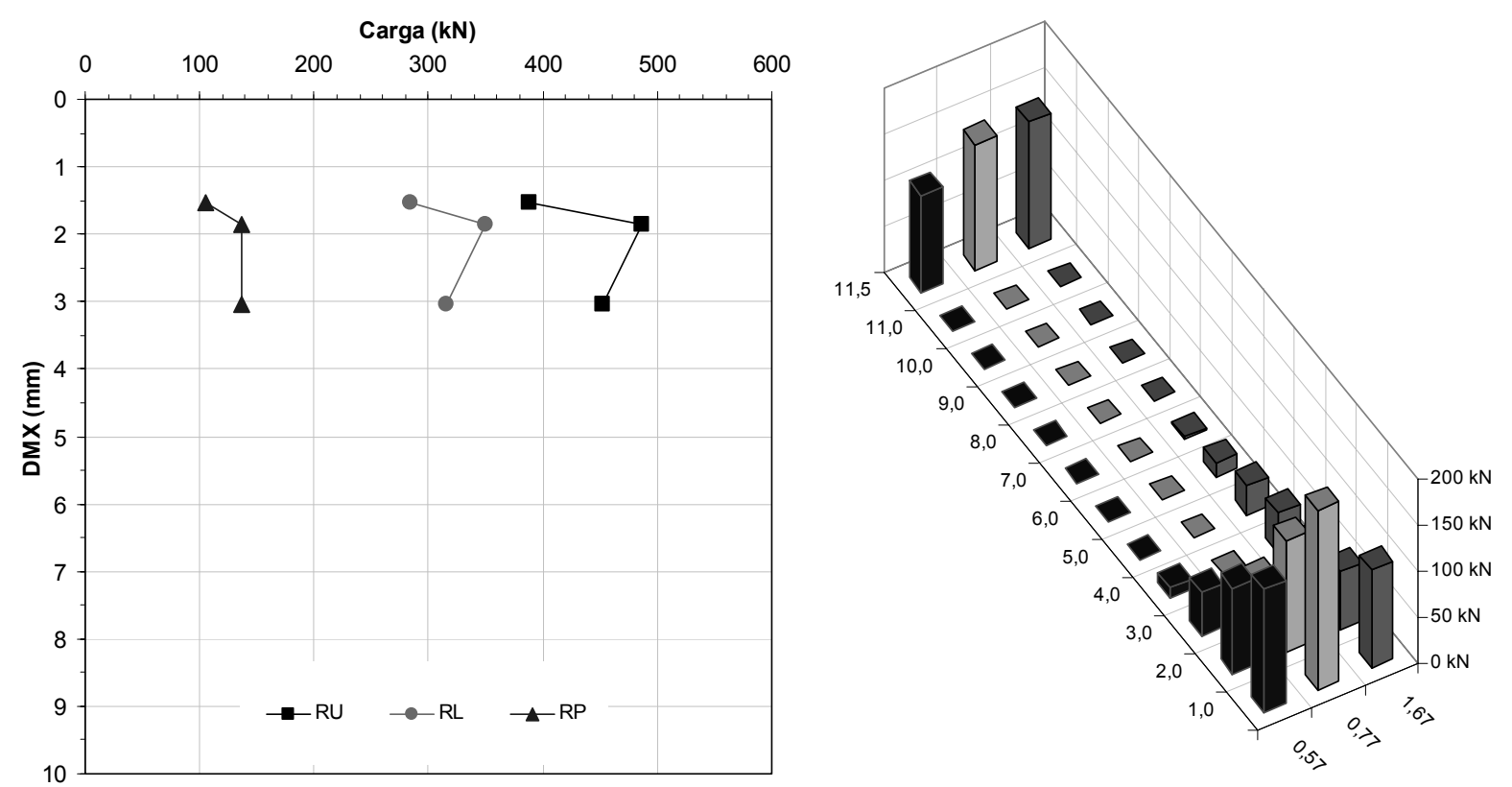

Figura 5.34 - Prova de carga dinâmica na estaca B11(BA) - Ensaio, sem pré-inundação 

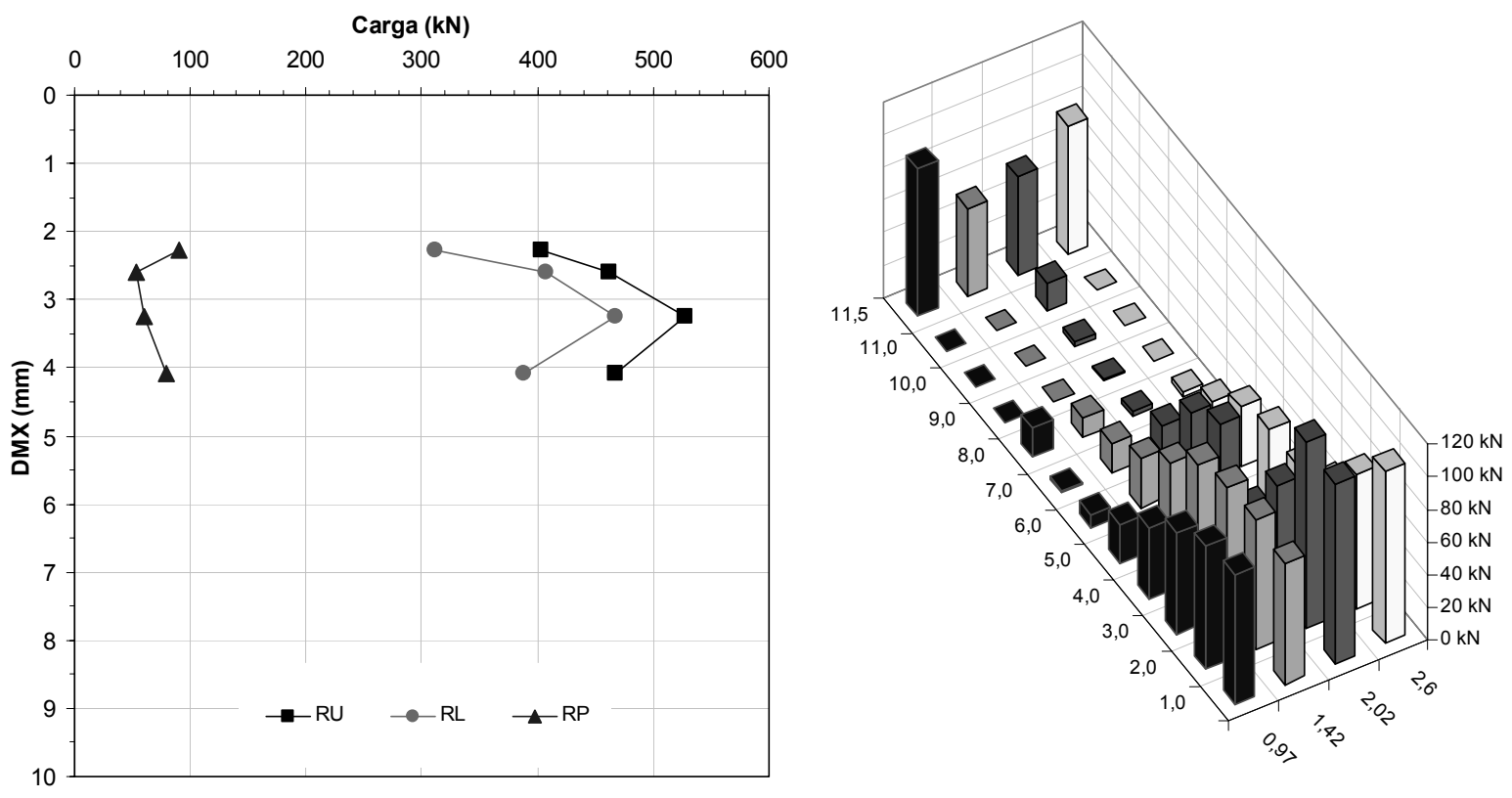

Figura 5.35 - Prova de carga dinâmica na estaca B11(BA) - Reensaio, sem pré-inundação
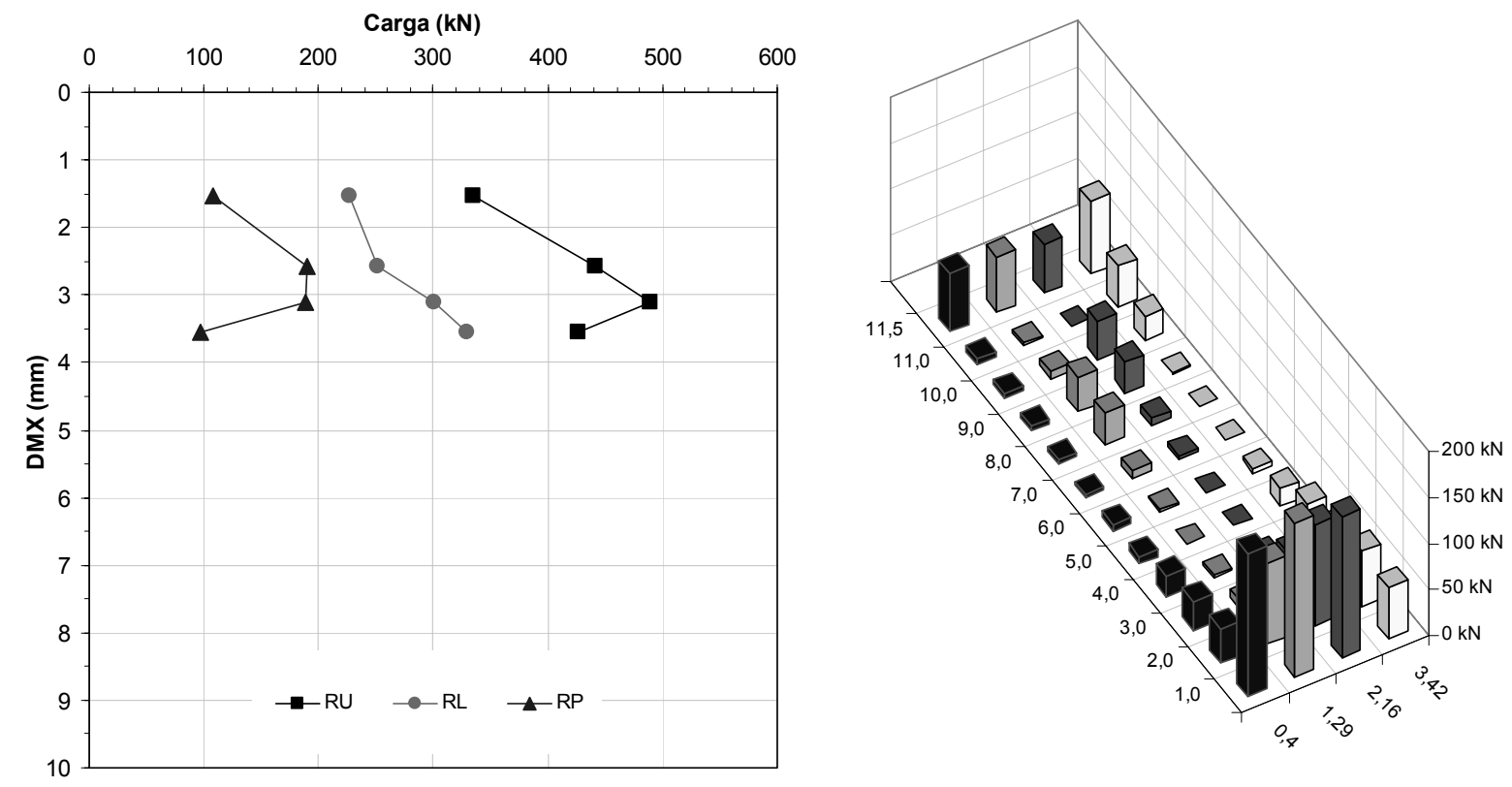

Figura 5.36 - Prova de carga dinâmica na estaca B19(BA) - Ensaio, com pré-inundação 

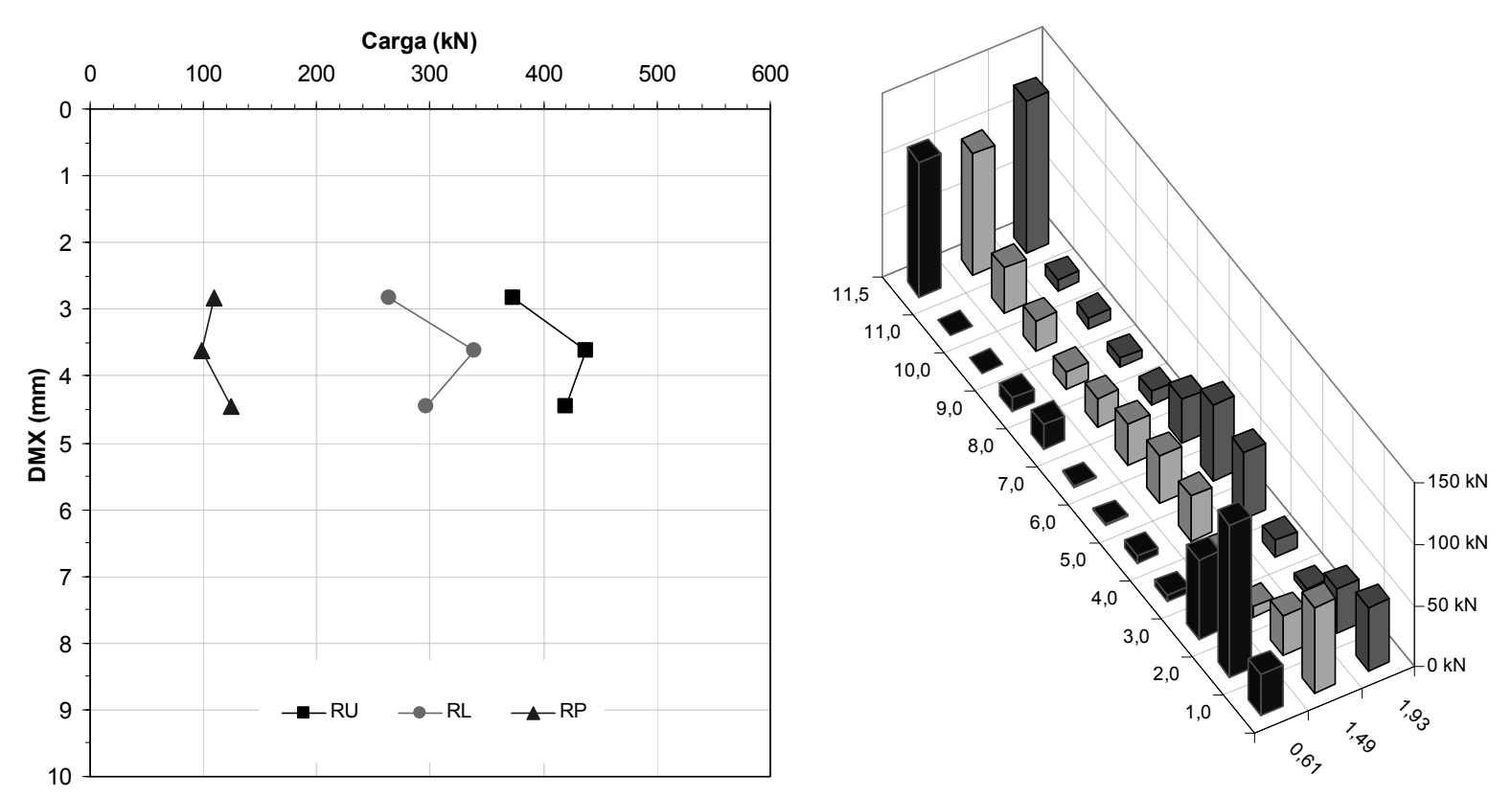

Figura 5.37 - Prova de carga dinâmica na estaca B19(BA) - Reensaio, com pré-inundação

A distribuição de carga ao longo da estaca B4(O) também apresentou comportamento similar ao observado nas estacas $\mathrm{A} 1(\mathrm{O})$ e $\mathrm{A} 4(\mathrm{O})$. A ruptura foi atingida sob pequenas $\mathrm{h}_{\text {queda }}$ do martelo, variando entre 20 e $50 \mathrm{~cm}$ e com EMX variando entre 0,77 e 2,02 kJ. A resistência total apresentou um acréscimo de $15 \%$ em relação às estacas de referência.

\subsection{5- Análise dos resultados das PCDs}

Os resultados obtidos nos ensaios e reensaios em todas as estacas mostraram que a ruptura foi atingida para pequenas $h_{\text {queda }}$ do martelo, variando entre 20 e $80 \mathrm{~cm}$ e com EMX variando entre 0,70 e 3,52 kJ. Os valores de Match Quality (MQ) obtidos foram baixos, variando entre 0,56 e 2,24 e com um $\mathrm{MQ}_{\text {médio }}=1,09$.

Os resultados dos ensaios e reensaios mostraram que a distribuição das cargas obtidas em todas as estacas se alterou durante a seqüência de golpes, com a resistência no topo passando por um pico, diminuindo e transferindo carga para o trecho inferior e para a ponta. 
Este tipo de comportamento se apresentou de forma consistente em todas as PCDs, como uma tendência e permitiu prever a evolução da distribuição de cargas, de acordo com a evolução dos golpes.

Houve aumento da resistência total média para todos os tipos de estacas com ponta modificada em relação às de referência, indicando que as intervenções pesquisadas podem ser utilizadas para a melhoria do comportamento das estacas escavadas de pequeno diâmetro, permitindo atingir a carga estrutural nominal, com os equipamentos de perfuração usuais.

A Tabela 5.7 mostra o resumo dos resultados dos ensaios das PCDs da pesquisa.

Tabela 5.7 - Resumo dos resultados dos ensaios

\begin{tabular}{|c|c|c|c|c|c|c|c|c|c|c|c|c|c|}
\hline \multirow{2}{*}{ Tipo } & \multirow{2}{*}{ Estaca } & \multirow{2}{*}{$\begin{array}{c}\text { Pré } \\
\text { inund. }\end{array}$} & \multicolumn{2}{|c|}{$M Q$} & \multicolumn{2}{|c|}{ Golpe } & \multicolumn{3}{|c|}{ Resistências (kN) } & \multicolumn{3}{|c|}{ RU } & \multirow[b]{2}{*}{ Obs. } \\
\hline & & & mín & máx & $\mathrm{H}(\mathrm{cm})$ & EMX(kJ) & $\mathrm{RU}$ & $\mathrm{RL}$ & $\mathrm{RP}$ & média & s & CV & \\
\hline \multirow{3}{*}{ Original } & $\mathrm{A} 1(\mathrm{O})$ & \multirow{2}{*}{ Não } & 0,77 & 1,28 & 80 & 2,40 & 338 & 199 & 139 & \multirow{2}{*}{377} & \multirow{2}{*}{54} & \multirow{2}{*}{$14 \%$} & \multirow{2}{*}{ referência } \\
\hline & $\mathrm{A} 4(\mathrm{O})$ & & 0,71 & 1,60 & 40 & 1,03 & 415 & 305 & 110 & & & & \\
\hline & $\mathrm{B} 4(\mathrm{O})$ & Sim & 1,39 & 1,78 & 60 & 1,45 & 362 & 290 & 72 & 362 & 0 & $0 \%$ & $4 \%$ \\
\hline \multirow{3}{*}{$\begin{array}{c}\text { Limpa com } \\
\text { Caçamba }\end{array}$} & $\mathrm{B} 8(\mathrm{LC})$ & \multirow{3}{*}{ Não } & 0,80 & 1,07 & 40 & 0,85 & 463 & 401 & 62 & \multirow{3}{*}{483} & \multirow{3}{*}{25} & \multirow{3}{*}{$5 \%$} & \multirow{3}{*}{$\uparrow \mathbf{2 8 \%}$} \\
\hline & B10(LC) & & 0,73 & 0,96 & 60 & 1,11 & 511 & 476 & 35 & & & & \\
\hline & C8(LC) & & 0,61 & 0,99 & 60 & 1,99 & 475 & 411 & 64 & & & & \\
\hline \multirow{3}{*}{$\begin{array}{c}\text { Solo } \\
\text { Melhorado }\end{array}$} & A8(SM) & \multirow{3}{*}{ Não } & 1,03 & 1,78 & 40 & 0,70 & 550 & 500 & 50 & \multirow{3}{*}{511} & \multirow{3}{*}{36} & \multirow{3}{*}{$7 \%$} & \multirow{3}{*}{$\uparrow 36 \%$} \\
\hline & B9(SM) & & 0,79 & 1,64 & 50 & 0,97 & 480 & 413 & 67 & & & & \\
\hline & C10(SM) & & 0,63 & 1,00 & 60 & 0,94 & 503 & 388 & 115 & & & & \\
\hline \multirow{3}{*}{$\begin{array}{l}\text { "Bucha } \\
\text { Strauss" }\end{array}$} & A9(BS) & \multirow{3}{*}{ Não } & 0,75 & 1,55 & 60 & 1,69 & 371 & 328 & 43 & \multirow{3}{*}{423} & \multirow{3}{*}{45} & \multirow{3}{*}{$11 \%$} & \multirow{3}{*}{$\uparrow 12 \%$} \\
\hline & $\mathrm{A} 10$ (BS) & & 0,70 & 1,06 & 60 & 2,16 & 448 & 395 & 53 & & & & \\
\hline & C9(BS) & & 0,64 & 0,71 & 50 & 1,10 & 451 & 403 & 48 & & & & \\
\hline \multirow{4}{*}{$\begin{array}{c}\text { Base } \\
\text { Alargada }\end{array}$} & $\mathrm{A} 11(\mathrm{BA})$ & & 1,21 & 1,47 & 40 & 1,31 & 346 & 278 & 68 & & & & \\
\hline & A12(BA) & Não & 1,04 & 1,37 & 50 & 1,39 & 468 & 404 & 64 & 433 & 76 & $18 \%$ & $\uparrow 15 \%$ \\
\hline & $\mathrm{B} 11(\mathrm{BA})$ & & 0,88 & 1,44 & 20 & 0,77 & 486 & 350 & 136 & & & & \\
\hline & B19(BA) & Sim & 0,94 & 1,40 & 50 & 1,13 & 488 & 300 & 188 & 488 & 0 & $0 \%$ & $\uparrow 29 \%$ \\
\hline
\end{tabular}

Os resultados dos ensaios mostraram que houve aumento da resistência total média para todos os tipos de estacas com ponta modificada em relação às de referência. Os aumentos variaram entre $36 \%$ para as estacas do tipo solo melhorado (SM) e $12 \%$ para as estacas do tipo "bucha de Strauss" (BS).

Com relação á condição de pré-inundação, o resultado do ensaio mostrou que houve uma redução de $4 \%$ da resistência total em relação às estacas sem pré-inundação. 
A Tabela 5.8 mostra o resumo dos resultados dos reensaios das PCDs da pesquisa.

Tabela 5.8 - Resumo dos resultados dos reensaios

\begin{tabular}{|c|c|c|c|c|c|c|c|c|c|c|c|c|c|}
\hline \multirow{2}{*}{ Tipo } & \multirow{2}{*}{ Estaca } & \multirow{2}{*}{$\begin{array}{c}\text { Pré } \\
\text { inund. }\end{array}$} & \multicolumn{2}{|c|}{$M Q$} & \multicolumn{2}{|c|}{ Golpe } & \multicolumn{3}{|c|}{ Resistências (kN) } & \multicolumn{3}{|c|}{ RU } & \multirow[b]{2}{*}{ Obs. } \\
\hline & & & mín & máx & $\mathrm{H}(\mathrm{cm})$ & EMX(kJ) & $\mathrm{RU}$ & $\mathrm{RL}$ & $\mathrm{RP}$ & média & $\mathrm{s}$ & CV & \\
\hline \multirow{3}{*}{ Original } & $\mathrm{A} 1(\mathrm{O})$ & \multirow{2}{*}{ Não } & 1,14 & 1,29 & 60 & 2,07 & 453 & 330 & 123 & \multirow{2}{*}{492} & \multirow{2}{*}{54} & \multirow{2}{*}{$11 \%$} & \multirow{2}{*}{$\uparrow 30 \%$} \\
\hline & $\mathrm{A} 4(\mathrm{O})$ & & 0,90 & 1,28 & 80 & 2,66 & 530 & 415 & 115 & & & & \\
\hline & $\mathrm{B} 4(\mathrm{O})$ & Sim & 1,25 & 1,65 & 60 & 1,90 & 491 & 393 & 98 & 491 & 0 & $0 \%$ & $\uparrow 30 \%$ \\
\hline \multirow{3}{*}{$\begin{array}{c}\text { Limpa com } \\
\text { Caçamba }\end{array}$} & B8(LC) & \multirow{3}{*}{ Não } & 0,73 & 2,24 & 80 & 3,52 & 513 & 376 & 137 & \multirow{3}{*}{474} & \multirow{3}{*}{36} & \multirow{3}{*}{$8 \%$} & \multirow{3}{*}{$\uparrow \mathbf{2 6 \%}$} \\
\hline & B10(LC) & & 0,84 & 0,94 & 60 & 1,46 & 442 & 391 & 51 & & & & \\
\hline & C8(LC) & & 0,73 & 1,00 & 40 & 1,32 & 466 & 416 & 50 & & & & \\
\hline \multirow{3}{*}{$\begin{array}{c}\text { Solo } \\
\text { Melhorado }\end{array}$} & A8(SM) & \multirow{3}{*}{ Não } & 0,91 & 1,11 & 60 & 2,53 & 502 & 467 & 35 & \multirow{3}{*}{491} & \multirow{3}{*}{43} & \multirow{3}{*}{$9 \%$} & \multirow{3}{*}{$\uparrow 30 \%$} \\
\hline & B9(SM) & & 0,74 & 0,95 & 80 & 3,26 & 444 & 396 & 48 & & & & \\
\hline & C10(SM) & & 0,62 & 0,83 & 60 & 1,77 & 528 & 482 & 46 & & & & \\
\hline \multirow{3}{*}{$\begin{array}{l}\text { "Bucha } \\
\text { Strauss" }\end{array}$} & A9(BS) & \multirow{3}{*}{ Não } & 0,56 & 1,31 & 40 & 1,07 & 393 & 324 & 69 & \multirow{3}{*}{451} & \multirow{3}{*}{59} & \multirow{3}{*}{$13 \%$} & \multirow{3}{*}{$\uparrow 20 \%$} \\
\hline & A10(BS) & & 0,74 & 1,28 & 60 & 1,41 & 510 & 378 & 132 & & & & \\
\hline & C9(BS) & & 0,71 & 1,05 & 60 & 2,07 & 449 & 365 & 84 & & & & \\
\hline \multirow{4}{*}{$\begin{array}{c}\text { Base } \\
\text { Alargada }\end{array}$} & $\mathrm{A} 11(\mathrm{BA})$ & & 1,12 & 1,14 & 40 & 1,67 & 340 & 266 & 74 & & & & \\
\hline & A12(BA) & Não & 1,16 & 1,39 & 40 & 1,10 & 421 & 349 & 72 & 429 & 94 & $22 \%$ & $\uparrow 14 \%$ \\
\hline & $\mathrm{B} 11(\mathrm{BA})$ & & 1,03 & 1,64 & 40 & 2,02 & 527 & 467 & 60 & & & & \\
\hline & B19(BA) & Sim & 1,31 & 1,68 & 50 & 1,49 & 438 & 339 & 99 & 438 & 0 & $0 \%$ & $\uparrow 16 \%$ \\
\hline
\end{tabular}

Os resultados dos reensaios mostraram que todos os tipos de estacas com ponta modificada, com exceção das estacas do tipo "bucha de Strauss" (BS), apresentaram pequena redução (entre 1 e $6 \%$ ) da resistência média total em relação aos resultados obtidos nos ensaios nas respectivas estacas. Os reensaios nas estacas do tipo "bucha de Strauss" (BS) apresentaram um aumento médio de $8 \%$ da resistência média total, em relação aos ensaios.

No caso das estacas originais, os reensaios mostraram um aumento de $30 \%$ na resistência média total, em relação aos ensaios.

Com relação à condição de pré-inundação, os reensaios mostraram um aumento de $34 \%$ da resistência total para as estacas originais e uma redução de $13 \%$ da resistência total para as estacas do tipo base alargada (BA). 


\section{4- Provas de carga estática (PCEs)}

As estacas $\mathrm{A} 1(\mathrm{O})$ e $\mathrm{A} 4(\mathrm{O})$ foram reensaiadas através de PCEs (3 $3^{\mathrm{a}}$ etapa), sem e com préinundação, entre os dias 31 de maio e 30 de junho de 2003, conforme seqüência mostrada no item 4.4.3, do capítulo 4 "Materiais e métodos". A pluviosidade nos dois dias que as antecederam e nos dias dos ensaios está mostrada na Tabela 5.9.

Tabela 5.9 - Pluviosidade no período das PCEs - 3aa etapa (2003)

\begin{tabular}{|c|c|c|c|c|c|c|}
\hline Dia & 29/mai & $30 / m a i$ & $31 / \mathbf{m a i}^{(P C E 1)}$ & 02/jun & 03/jun & 04/jun ${ }^{(P C E 2)}$ \\
\hline Pluviosidade (mm) & 0,0 & 0,0 & 0,0 & 0,0 & 0,0 & 0,0 \\
\hline Dia & 05/jun & 06/jun & $07 / j u n^{(P C E 3)}$ & 08/jun & 09/jun & 10/jun (PCE4) \\
\hline Pluviosidade ( $\mathrm{mm})$ & 13,4 & 3,4 & 0,2 & 0,0 & 0,0 & 0,0 \\
\hline Dia & 23/jun & 24/jun & 25/jun ${ }^{(P C E 5)}$ & 28/jun & 29/jun & 30/jun ${ }^{(P C E 6)}$ \\
\hline Pluviosidade ( $\mathrm{mm}$ ) & 0,0 & 0,0 & 0,0 & 0,0 & 0,0 & 0,0 \\
\hline
\end{tabular}

\subsection{1- Estaca A1(O)}

A curva carga $\times$ recalque obtida para o primeiro ensaio estático $(\mathrm{PCE}-2)$ na estaca $\mathrm{A} 1(\mathrm{O})$ está apresentada na Figura 5.38. O ensaio foi executado sem pré-inundação e a carga máxima aplicada foi de $495 \mathrm{kN}$, gerando um recalque plástico de 42,26 mm. 


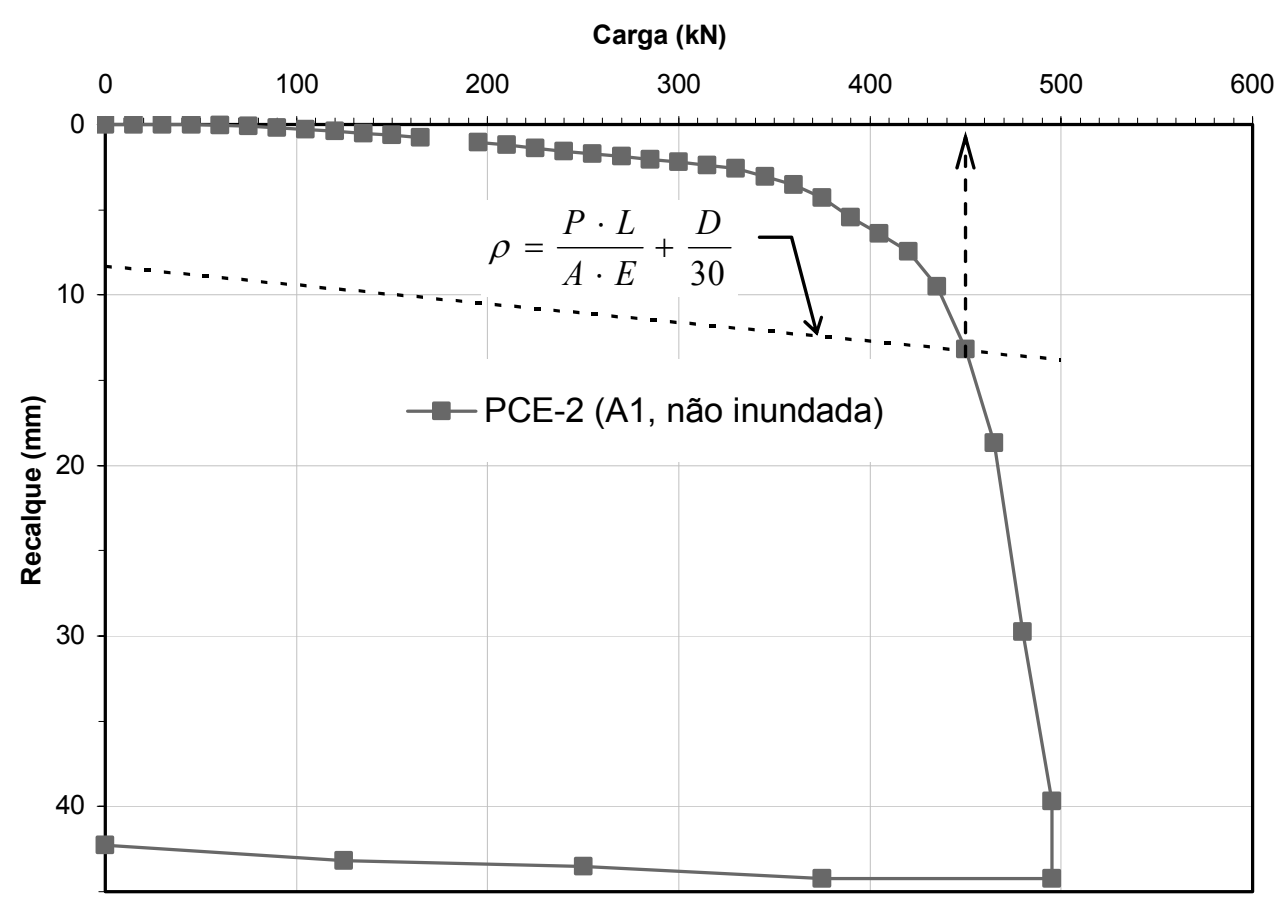

Figura 5.38 - Curva carga $\mathrm{x}$ recalque do primeiro ensaio estático na estaca $\mathrm{A} 1(0)$

Esta curva carga $\times$ recalque foi interpretada por dois critérios de ruptura convencional, chegando-se aos seguintes resultados de capacidade de carga do sistema estaca-solo:

(a) Critério de TERZAGHI (1942) - carga correspondente ao recalque de 10\% $\phi_{\text {estaca: }}$ : $\mathrm{R}_{\mathrm{u}}=472 \mathrm{kN}$

(b) Critério da NBR-6122 (1996) - interseção da curva carga $\times$ recalque com a reta de equação $\rho=\frac{P \cdot L}{A \cdot E}+\frac{D}{30}: \mathrm{R}_{\mathrm{u}}=455 \mathrm{kN}$

A curva carga $\times$ recalque obtida para o primeiro reensaio estático $(\mathrm{PCE}-3)$ nesta estaca está apresentada na Figura 5.39. O reensaio foi executado com pré-inundação por 48 horas, três dias depois da última PCE nesta estaca e a carga máxima aplicada foi de $495 \mathrm{kN}$, gerando um recalque plástico de $37,94 \mathrm{~mm}$. 


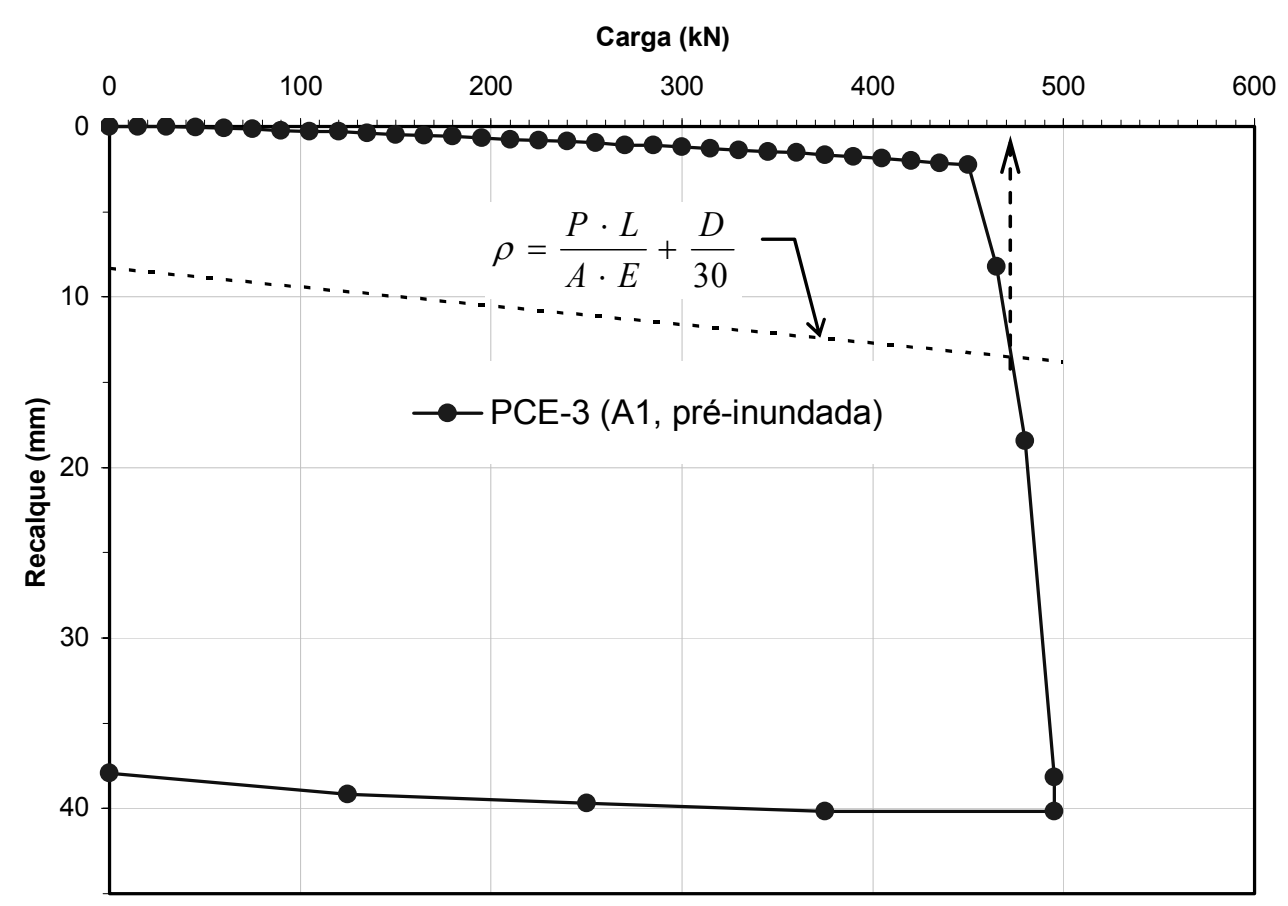

Figura 5.39 - Curva carga x recalque do primeiro reensaio estático na estaca $\mathrm{A} 1(0)$

Esta curva carga $\times$ recalque foi interpretada por dois critérios de ruptura convencional, chegando-se aos seguintes resultados de capacidade de carga do sistema estaca-solo:

(a) Critério de TERZAGHI (1942) - carga correspondente ao recalque de 10\% $\phi_{\text {estaca: }}$ : $\mathrm{R}_{\mathrm{u}}=485 \mathrm{kN}$

(b) Critério da NBR-6122 (1996) - interseção da curva carga $\times$ recalque com a reta de equação $\rho=\frac{P \cdot L}{A \cdot E}+\frac{D}{30}: \mathrm{R}_{\mathrm{u}}=476 \mathrm{kN}$

A Figura 5.40 ilustra estas duas curvas carga $\times$ recalque, plotadas com o recalque plástico acumulado. 


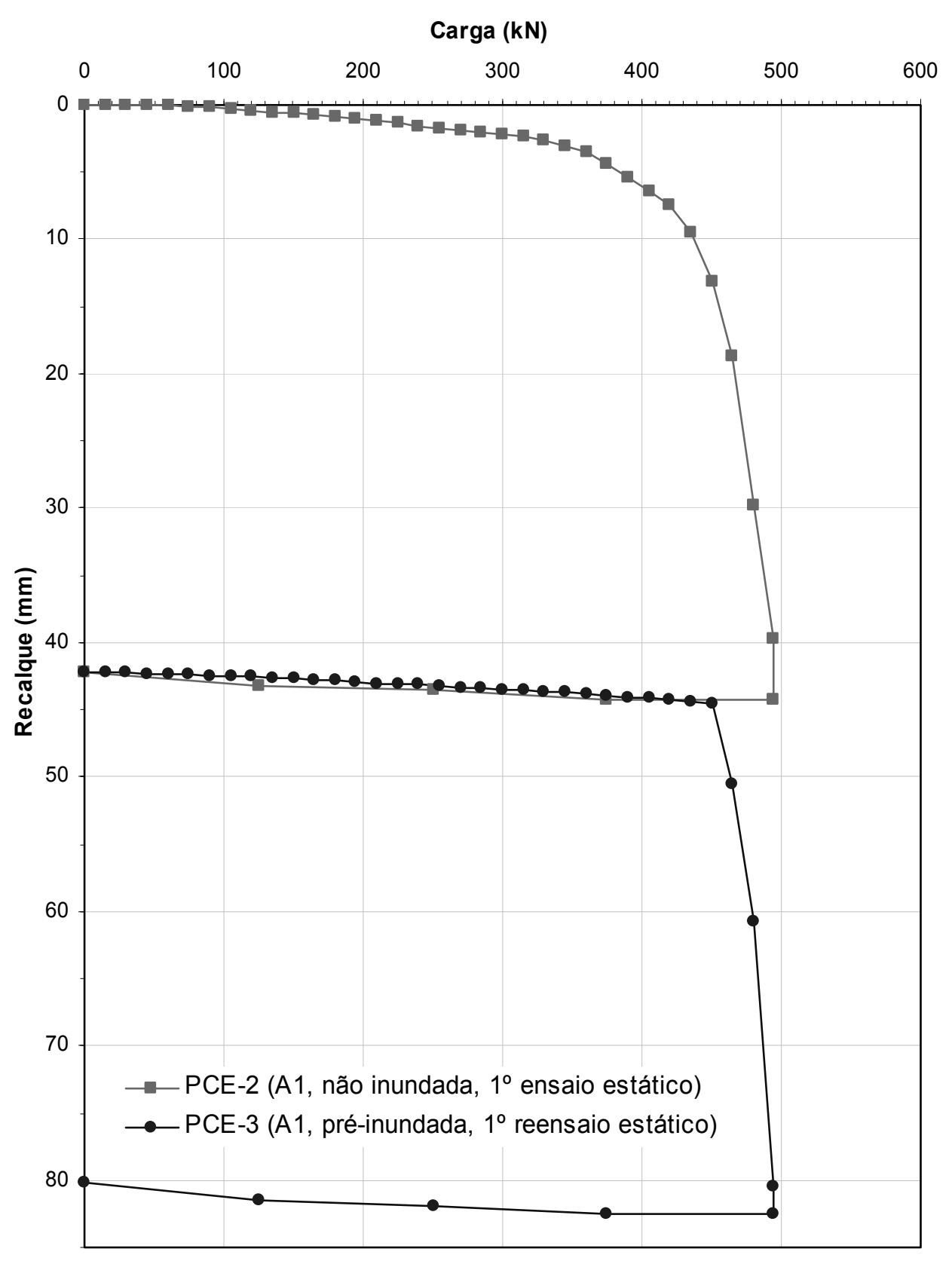

Figura 5.40 - Curva carga x recalque dos ensaio e reensaio estáticos na estaca A1(0)

O sistema estaca-solo apresentou um comportamento linear de baixa deformação até cerca de dois terços da carga máxima aplicada na PCE-2, quando a deformação se tornou não linear.

$\mathrm{Na}$ PCE-3, este comportamento foi mais evidente, com o trecho linear atingindo cerca de $90 \%$ da carga máxima aplicada, para a mesma deformação encontrada na primeira PCE.

A realização prévia de dois ensaios dinâmicos e um estático contribuiu para reduzir os recalques nos estágios iniciais das provas de carga estáticas subseqüentes. O descarregamento 
mostrou que quase toda a deformação resultou permanente. Comportamento semelhante já foi observado em estacas curtas, do tipo broca manual, de 3 e de $6 \mathrm{~m}$ de comprimento, com diâmetros de 20 e de $25 \mathrm{~cm}$, anteriormente ensaiadas no CEEG (FERNAL et al., 2003; MIGUEL et al., 2003).

A capacidade de carga obtida pelo critério da NBR-6122 (1996) na PCE-2 mostra um acréscimo de $35 \%$ em relação à primeira PCD. A capacidade de carga também obtida pelo critério da NBR-6122 (1996)na PCE-3 mostra um acréscimo de 41 \% em relação à primeira PCD e um acréscimo de $4 \%$ em relação à primeira PCE. Isto se deve ao fato de que a realização das provas de carga prévias provocou uma maior mobilização da resistência de ponta, quando da realização das PCEs. O efeito da pré-inundação não foi suficiente para reduzir a capacidade de carga da estaca.

\subsection{2- Estaca $A 4(0)$}

A curva carga $\times$ recalque obtida para o primeiro ensaio estático $(\mathrm{PCE}-1)$ na estaca $\mathrm{A} 4(\mathrm{O})$ está apresentada na Figura 5.41. O ensaio foi executado sem pré-inundação e a carga máxima aplicada foi de $465 \mathrm{kN}$, gerando um recalque plástico de 27,34 mm. (kN). 


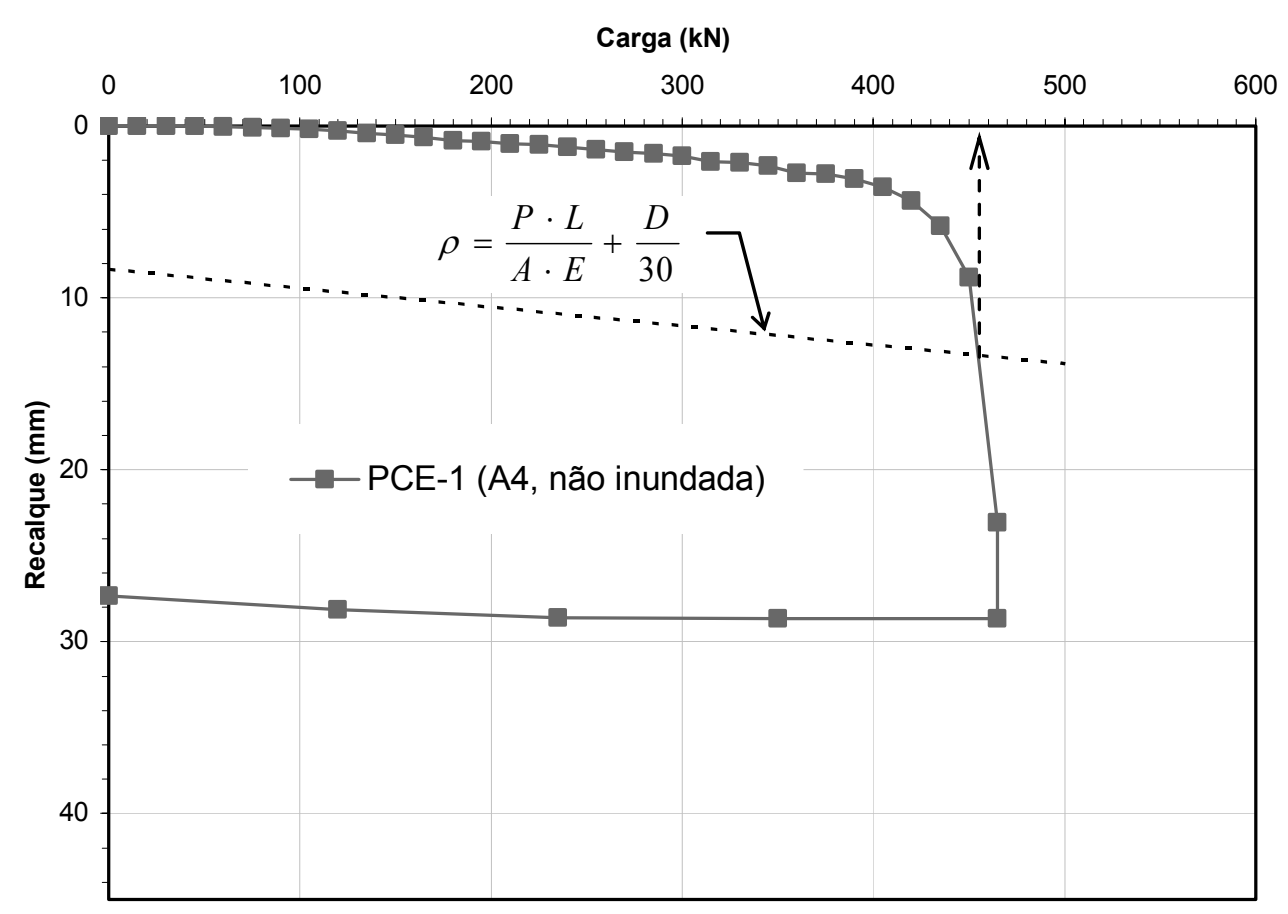

Figura 5.41 - Curva carga x recalque do primeiro ensaio estático na estaca $\mathrm{A} 4(0)$

Esta curva carga $\times$ recalque foi interpretada por dois critérios de ruptura convencional, chegando-se aos seguintes resultados de capacidade de carga do sistema estaca-solo:

(a) Critério de TERZAGHI (1942) - carga correspondente ao recalque de 10\% $\phi_{\text {estaca: }}$ : $\mathrm{R}_{\mathrm{u}}=465 \mathrm{kN}$

(b) Critério da NBR-6122 (1996) - interseção da curva carga $\times$ recalque com a reta de equação $\rho=\frac{P \cdot L}{A \cdot E}+\frac{D}{30}: \mathrm{R}_{\mathrm{u}}=455 \mathrm{kN}$

A curva carga $\times$ recalque obtida para o primeiro reensaio estático (PCE-4) nesta estaca está apresentada na Figura 5.42. O reensaio foi executado com pré-inundação por 48 horas, 10 dias depois da última PCE nesta estaca e a carga máxima aplicada foi de $435 \mathrm{kN}$, gerando um recalque plástico de $32,03 \mathrm{~mm}$. 


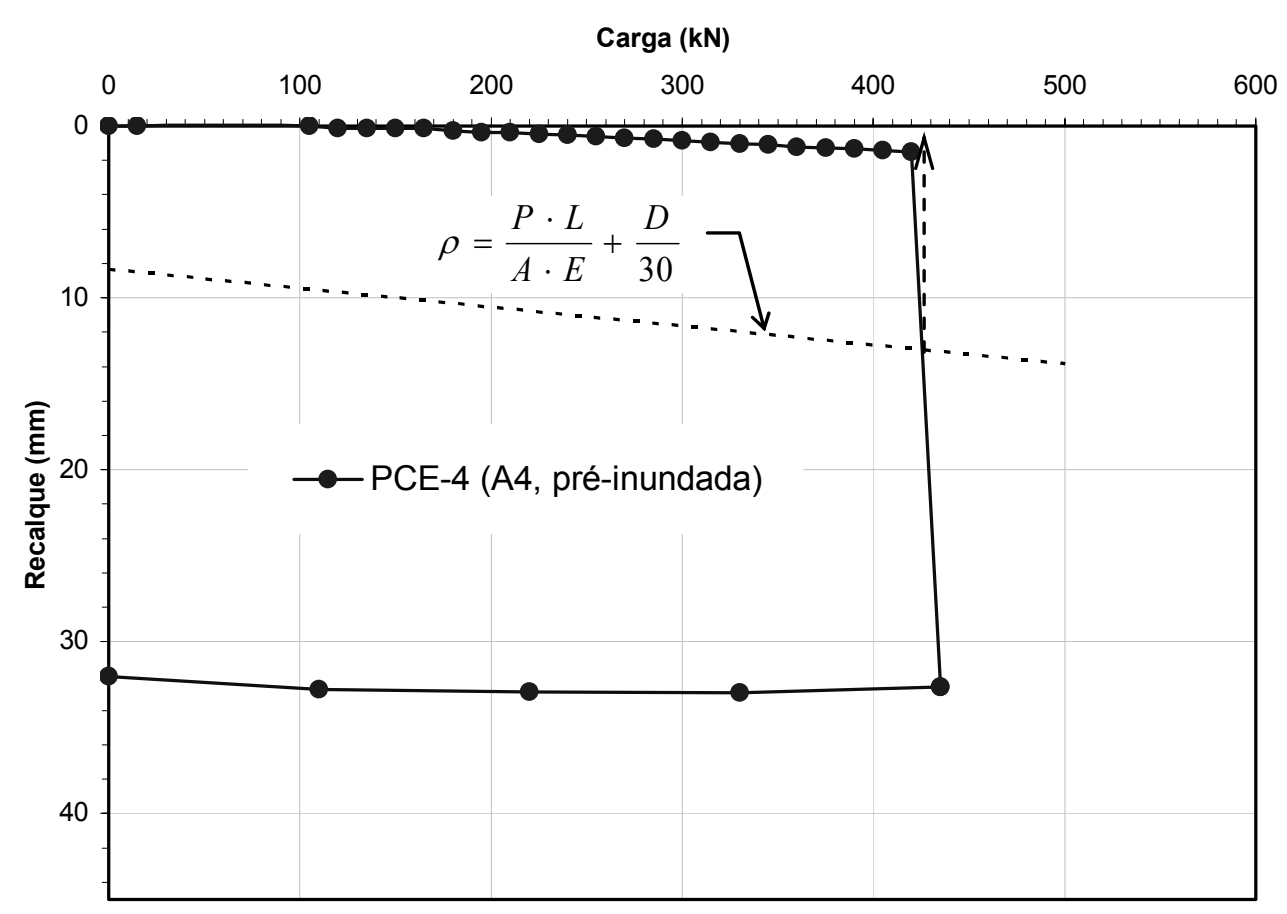

Figura 5.42 - Curva carga $x$ recalque do primeiro reensaio estático na estaca $A 4(0)$

Esta curva carga $\times$ recalque foi interpretada por dois critérios de ruptura convencional, chegando-se aos seguintes resultados de capacidade de carga do sistema estaca-solo:

(a) Critério de TERZAGHI (1942) - carga correspondente ao recalque de $10 \% \phi_{\text {estaca: }}$ : $\mathrm{R}_{\mathrm{u}}=430 \mathrm{kN}$

(b) Critério da NBR-6122 (1996) - interseção da curva carga $\times$ recalque com a reta de equação $\rho=\frac{P \cdot L}{A \cdot E}+\frac{D}{30}: \mathrm{R}_{\mathrm{u}}=425 \mathrm{kN}$

A capacidade de carga obtida pelo critério da NBR-6122 (1996)na PCE-1 mostrou um acréscimo de $10 \%$ em relação à primeira PCD e a capacidade de carga, também obtida pelo critério da NBR-6122 (1996), na PCE-4 mostrou um acréscimo de $2 \%$ em relação à primeira PCD e uma redução de $7 \%$ em relação à primeira PCE, em função da condição de préinundação. 
Após 15 dias da execução da PCE-4 nesta estaca foi executada a PCE-5, que constou de quatro ciclos rápidos, sendo que os três últimos constaram de um estágio único com a carga máxima obtida no ciclo anterior e teve como objetivo provocar um grande deslocamento na estaca e criar condições para a ocorrência de mudança de comportamento na PCE subseqüente. Estes reensaios foram executados sem pré-inundação e a carga máxima aplicada foi de $475 \mathrm{kN}$, gerando um recalque plástico de 162,92 mm.

As curvas carga $\times$ recalque obtidas para os segundo, terceiro, quarto e quinto reensaios estáticos da PCE-5 estão apresentadas na Figura 5.43, junto com as demais curvas desta estaca.

Cinco dias depois a PCE-5, foi executada, também sem pré-inundação, a PCE-6, com o objetivo de verificar se haveria mudança no comportamento da estaca. A carga máxima aplicada foi de $540 \mathrm{kN}$, gerando um recalque plástico de $46,84 \mathrm{~mm}$. A curva carga $\times$ recalque obtida está apresentada na Figura 5.43, junto com as demais curvas desta estaca.

A curva carga $\times$ recalque da PCE- 6 foi interpretada por dois critérios de ruptura convencional, chegando-se aos seguintes resultados de capacidade de carga do sistema estaca-solo:

(a) Critério de TERZAGHI (1942) - carga correspondente ao recalque de $10 \% \phi_{\text {estaca: }}$ : $\mathrm{R}_{\mathrm{u}}=520 \mathrm{kN}$

(b) Critério da NBR-6122 (1996) - interseção da curva carga $\times$ recalque com a reta de equação $\rho=\frac{P \cdot L}{A \cdot E}+\frac{D}{30}: \mathrm{R}_{\mathrm{u}}=505 \mathrm{kN}$

O sistema estaca-solo apresentou um comportamento linear de baixa deformação até cerca de 80\% da carga máxima aplicada na PCE-1, quando a deformação se tornou não linear. 


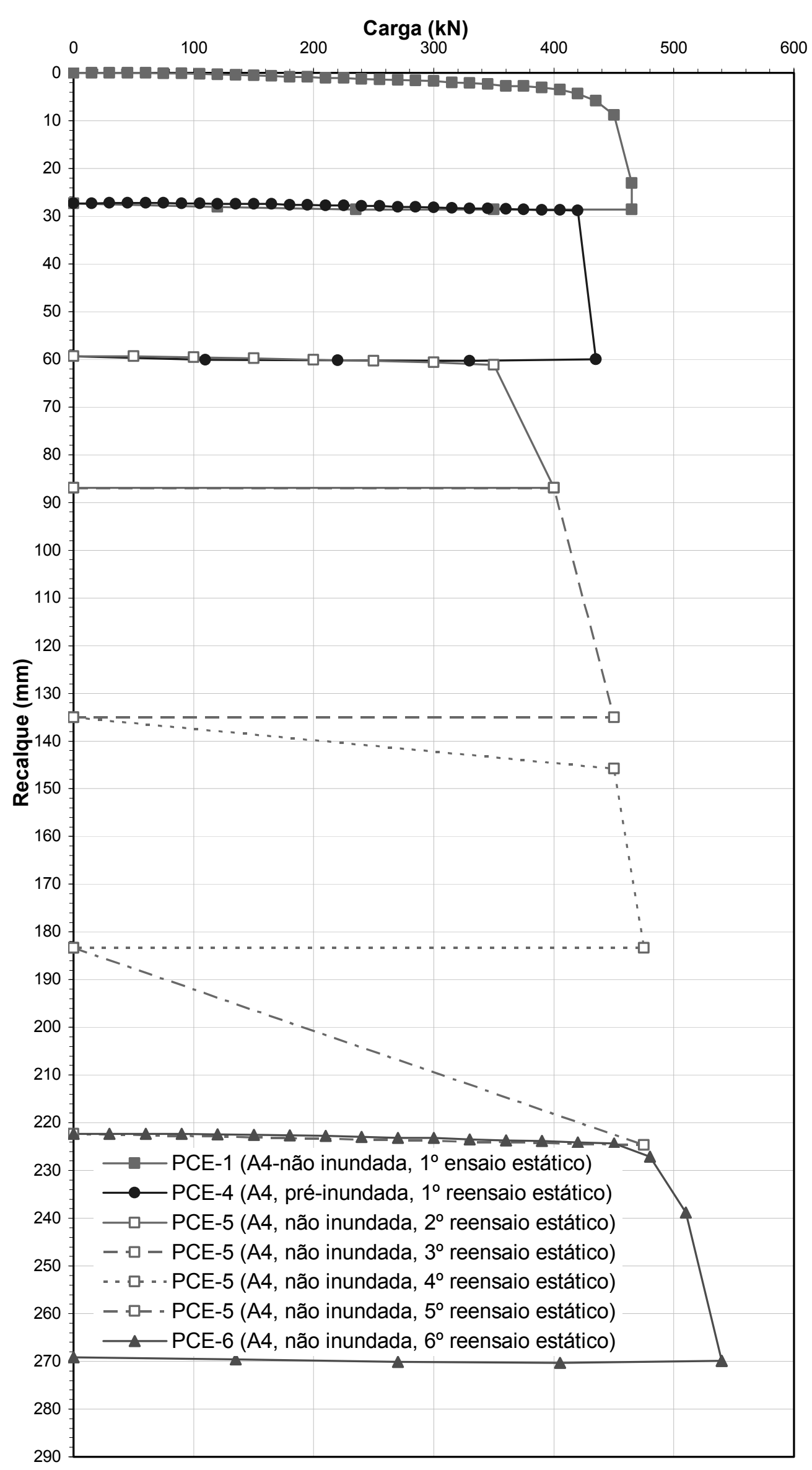

Figura 5.43 - Curvas carga x recalque de todos os ensaios e reensaios estáticos na estaca $A 4(0)$ 
$\mathrm{Na}$ PCE-6, este comportamento foi mais evidente, com o trecho linear atingindo aproximadamente $85 \%$ da carga máxima aplicada, para dois terços da deformação encontrada na primeira PCE-1.

A realização prévia de dois ensaios dinâmicos e, até, seis ciclos de carregamento estático contribuiu para reduzir os recalques nos estágios iniciais das provas de carga estáticas subseqüentes. O descarregamento mostrou que quase toda a deformação resultou permanente.

O ensaio de relaxação, descrito em 4.4.3 (Capítulo 4 - Materiais e métodos) e executado para a verificação da existência ou não de tensões residuais, foi iniciado no dia 1 de julho de 2003 e finalizado no dia 3 seguinte. O resultado obtido está apresentado na Figura 5.44. Os deslocamentos medidos no topo da estaca (relaxação), apesar de pequenos, ocorreram sempre no mesmo sentido e nos períodos diurnos. Nas seis primeiras horas ocorreram cerca de $70 \%$ das relaxações, ficando praticamente estacionados durante os períodos noturnos, com a ocorrência do restante da relação no segundo dia.

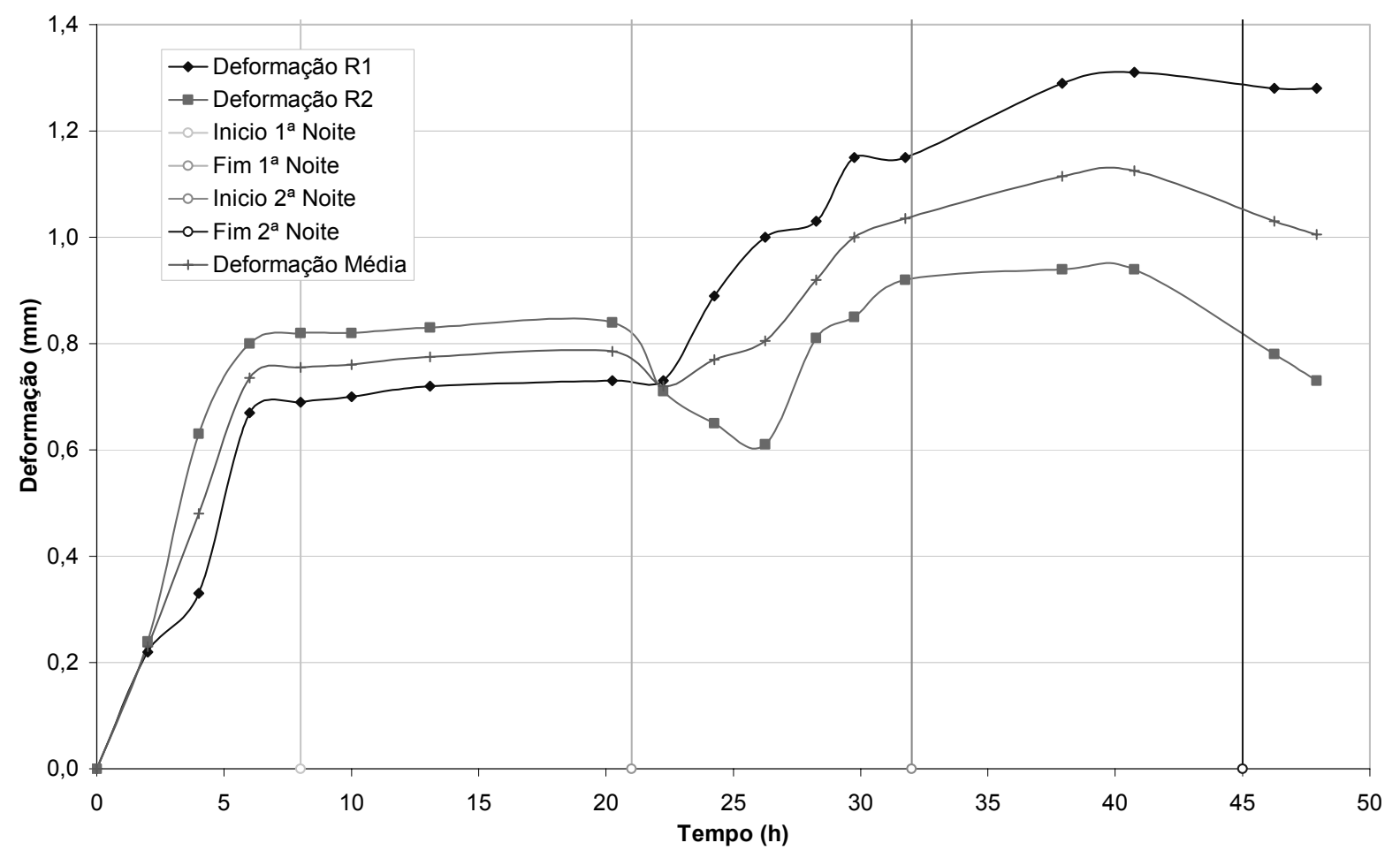

Figura 5.44 - Ensaio de relaxação para a verificação de tensões residuais na estaca A4 
A pluviosidade foi nula na quinzena anterior e durante o ensaio. Os resultados obtidos indicam a existência de tensões residuais de baixa intensidade, porém coerentes entre si. Ressalta-se que estas determinações foram feitas somente neste ensaio.

Sugere-se que a pesquisa seja continuada com a execução de ensaios que possam comprovar a ocorrência ou não de tensões residuais em estacas durante provas de carga dinâmicas e sua influência na interpretação dos resultados aqui obtidos. Estes ensaios podem ser provas de carga estáticas instrumentadas com strain gauges ou com tell tales.

\section{5- Inspeção das estacas}

A remoção das estacas $\mathrm{A} 1(\mathrm{O})$ e $\mathrm{B} 9(\mathrm{SM})$ permitiu as suas inspeções visuais e a conferência de medidas e de eventuais problemas de concretagem. A análise visual mostrou que ambas apresentaram bom preenchimento do concreto, de forma uniforme, nos primeiros $10 \mathrm{~m}$. No trecho final de ambas o concreto apresentou porosidade crescente até a ponta, embora não houvesse vazios importantes no concreto. Isto provavelmente ocorreu em função de um grau crescente de dificuldade de fluidez do concreto entre a armadura, atenuando a sua capacidade de auto-adensamento. As Figuras 5.45 e 5.46 ilustram a estaca $\mathrm{A} 1(\mathrm{O})$, com este efeito.

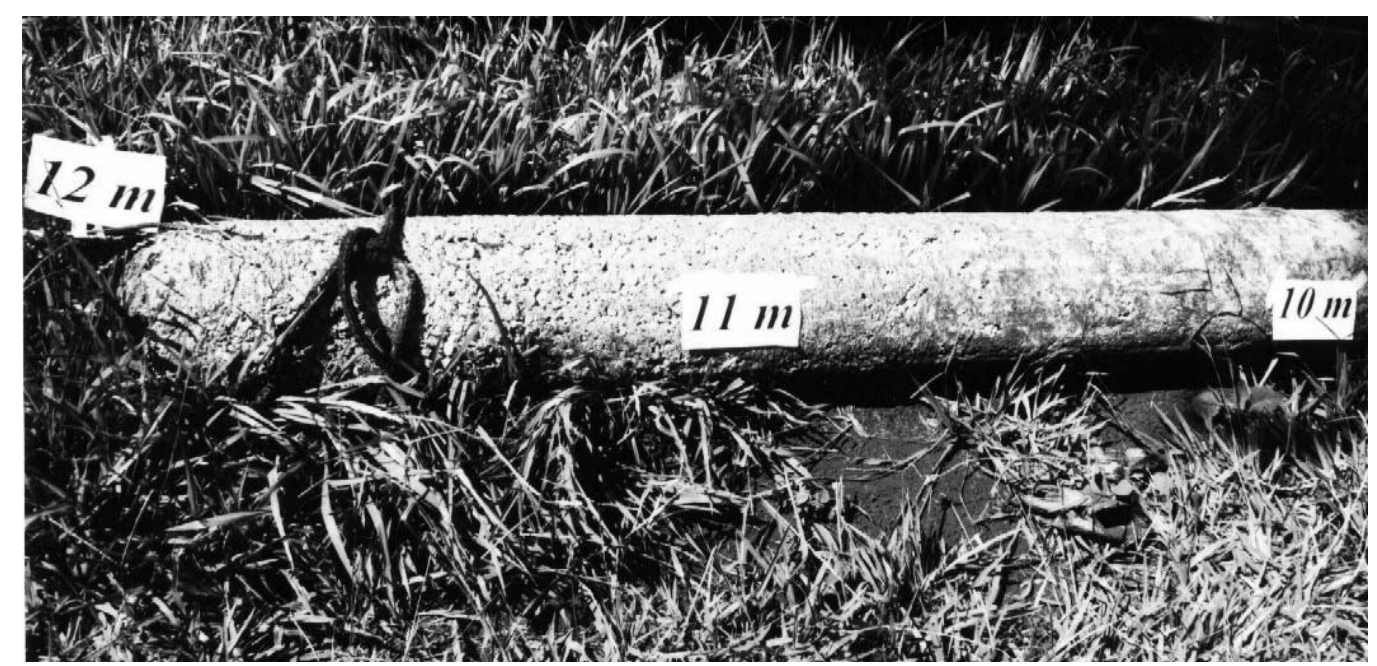

Figura 5.45 - Vista geral do trecho final da estaca A1(0) 


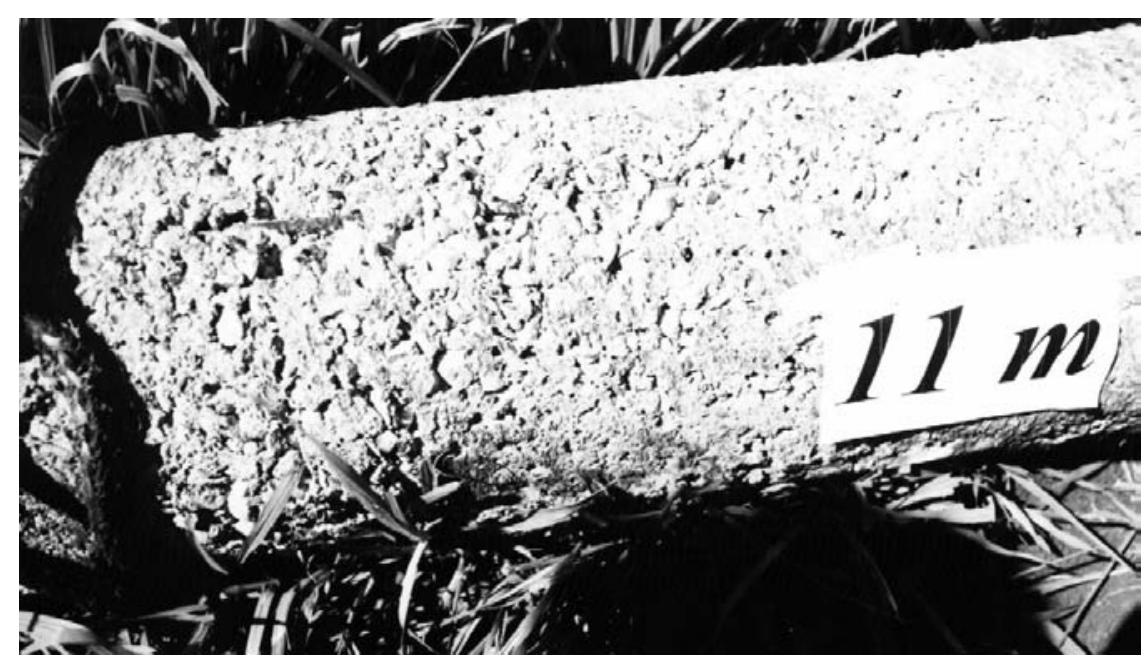

Figura 5.46 - Detalhe do trecho final da estaca $A 1(0)$

As Figuras 5.47 e 5.48 ilustram a estaca A4(O), com este efeito.

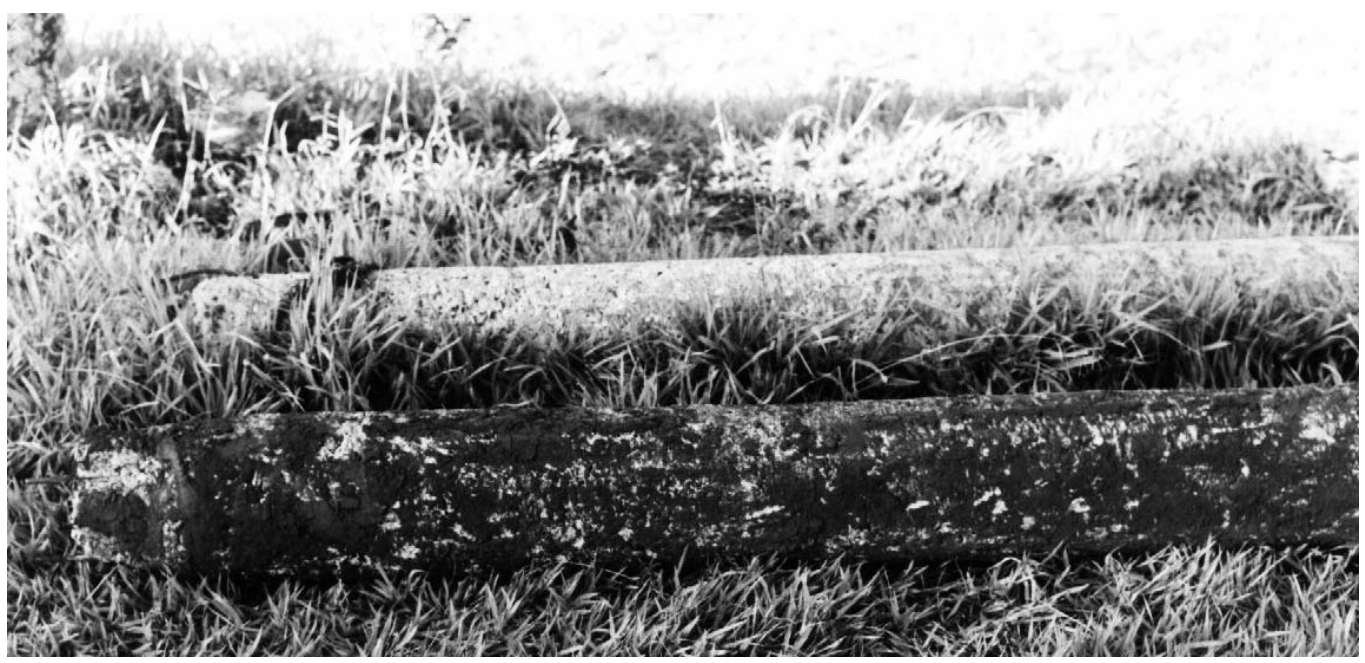

Figura 5.47 - Vista geral do trecho final da estaca $A 4(0)$ 


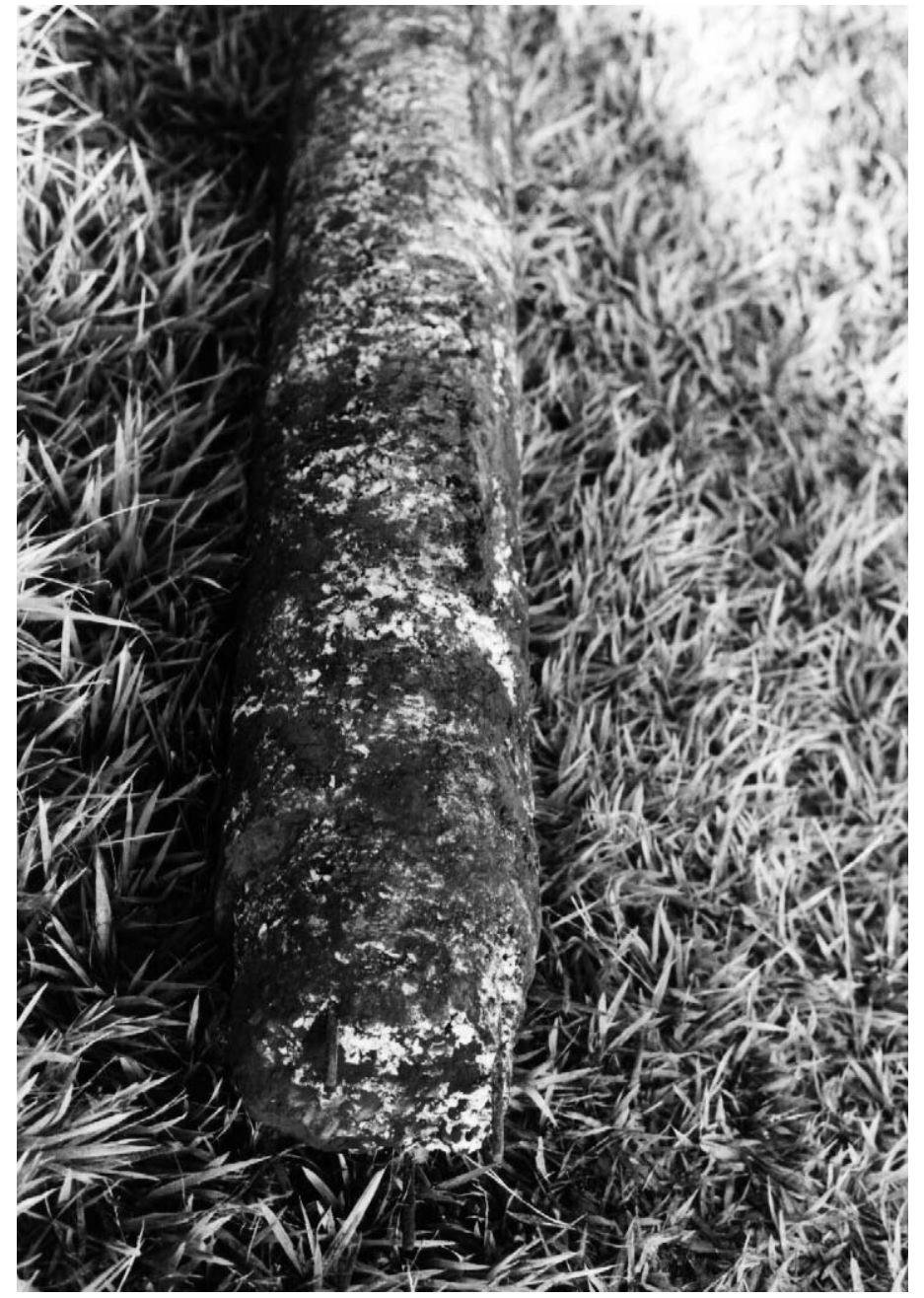

Figura 5.48 - Detalhe do trecho final da estaca A4(0)

Os volumes de solo solto observados no fundo da escavação das estacas do tipo original (O) foram compatíveis com o volume não retentivo do trado, calculado com base na sua geometria, acrescido de um empolamento de cerca de $30 \%$ (Figura 5.49).
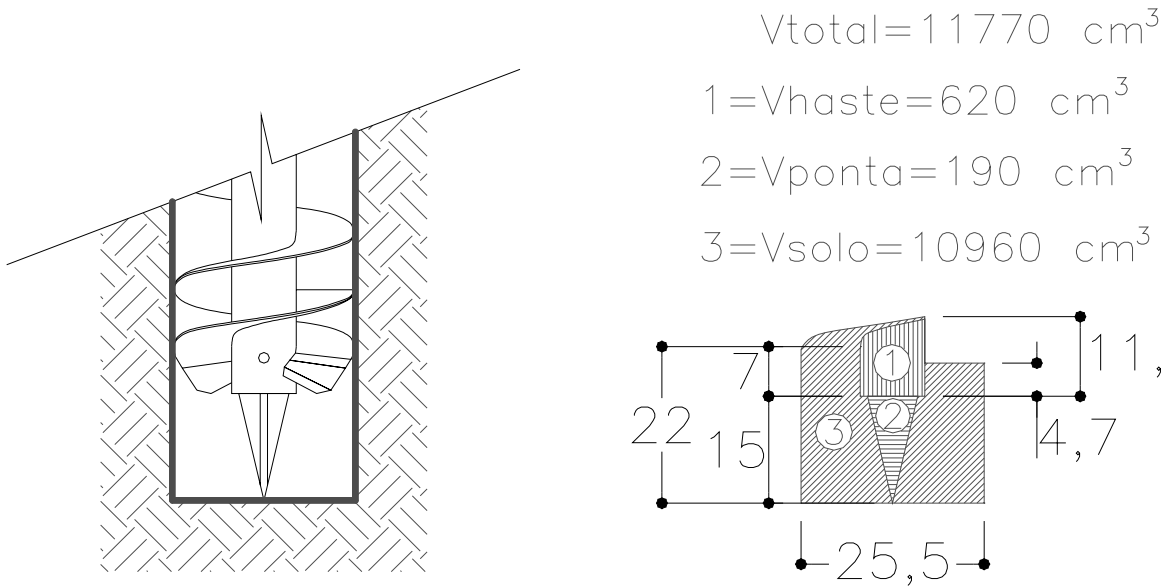

Figura 5.49 - Detalhe da ponta do trado e os volumes não retentivos 
As fotos das pontas das estacas A2(I), A3(I), A4(O), B1(O), B2(I), B3(I), B4(O), C3(I), C4(I), A8(SM), A9(BS), B8(LC), A11(BA), A12(BA) e B11(BA) estão ilustradas nas Figuras 5.50 a 5.64 .

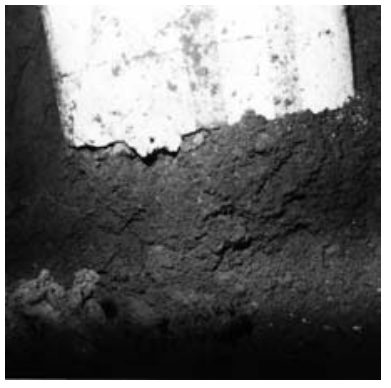

Figura 5.50 - Estaca A2(I)

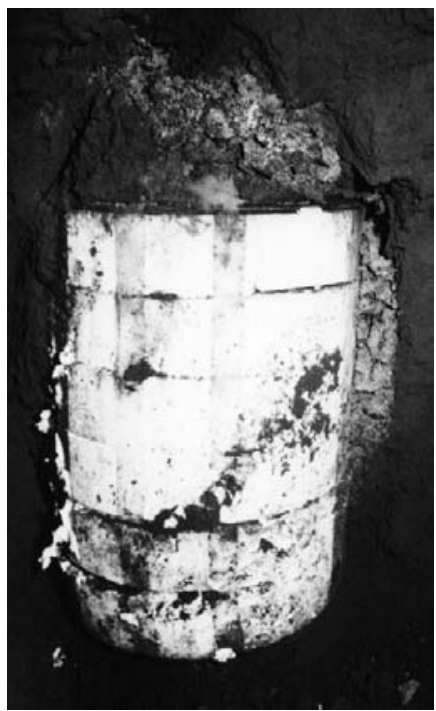

Figura 5.54 - Estaca B2(I)

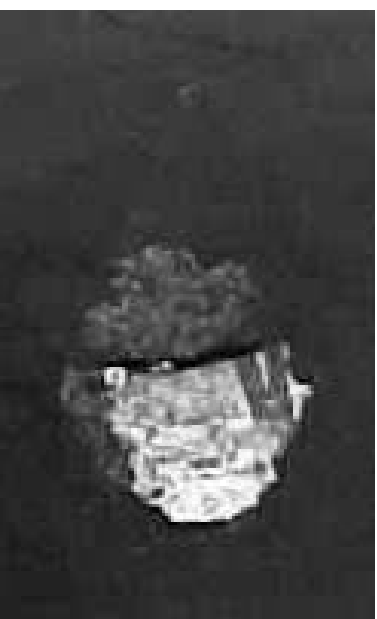

Figura 5.51 - Estaca A3(I)

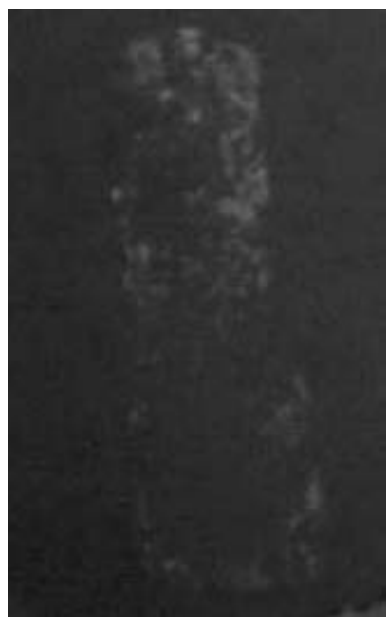

Figura 5.52 - Estaca $\mathrm{A} 4(0)$

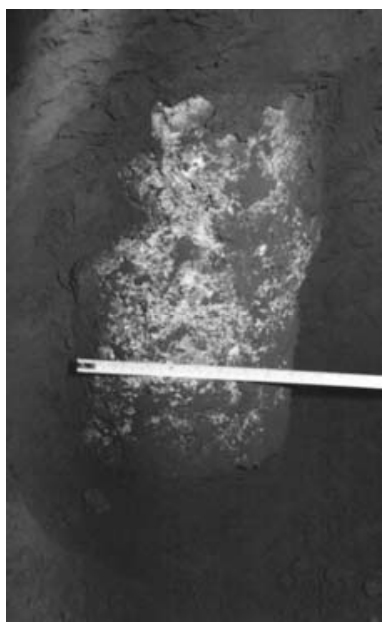

Figura 5.53 - Estaca B1(0)

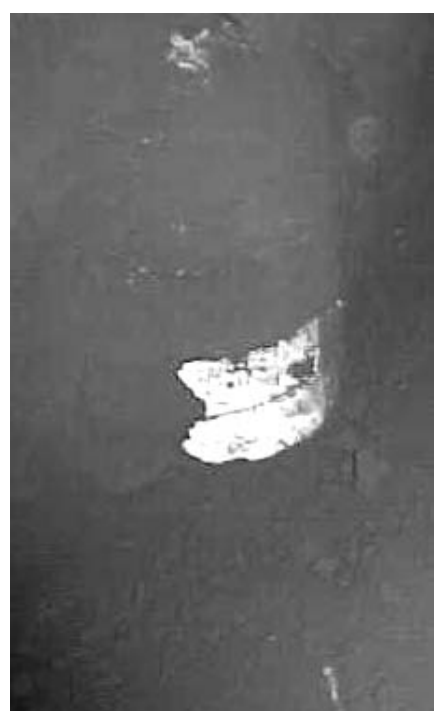

Figura 5.55 - Estaca B3(I)

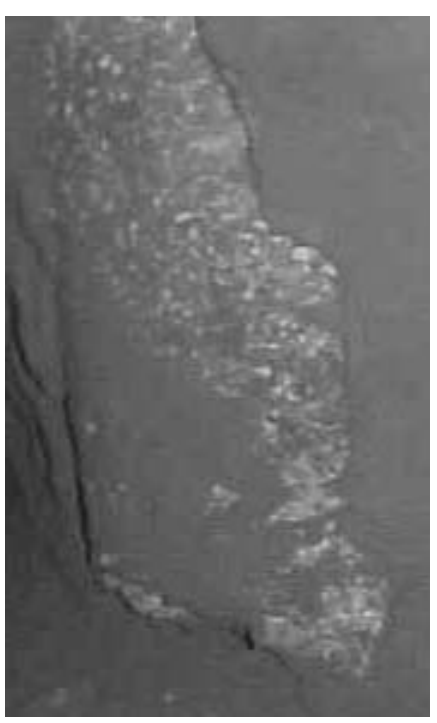

Figura 5.56 - Estaca B4(0) 


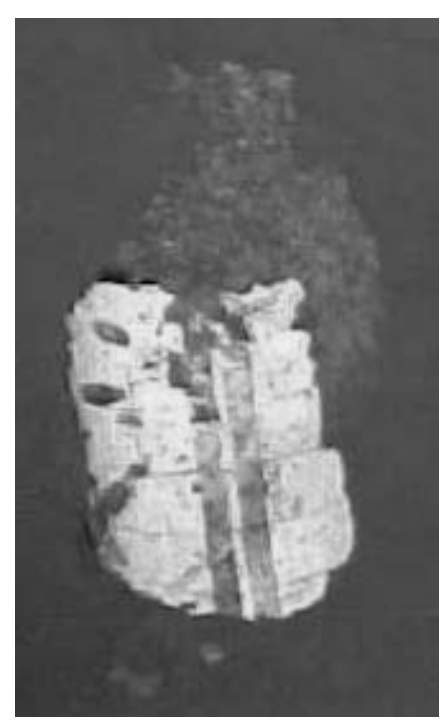

Figura 5.57 - Estaca C3(l)

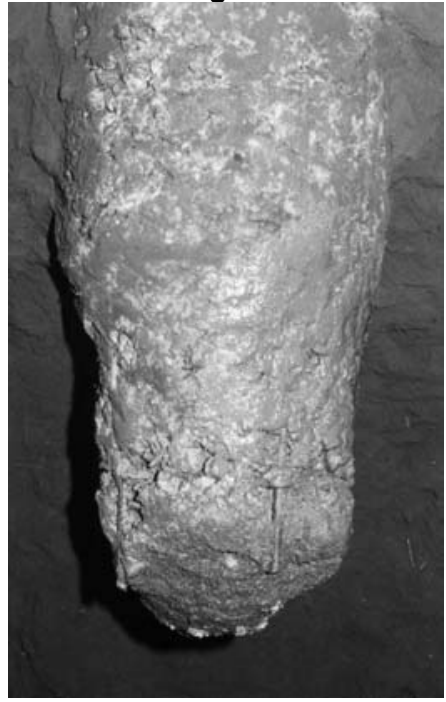

Figura 5.59 - Estaca A8(SM)

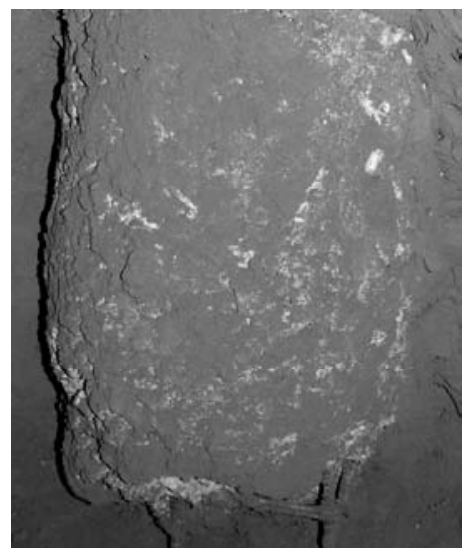

Figura 5.62 - Estaca A11(BA)

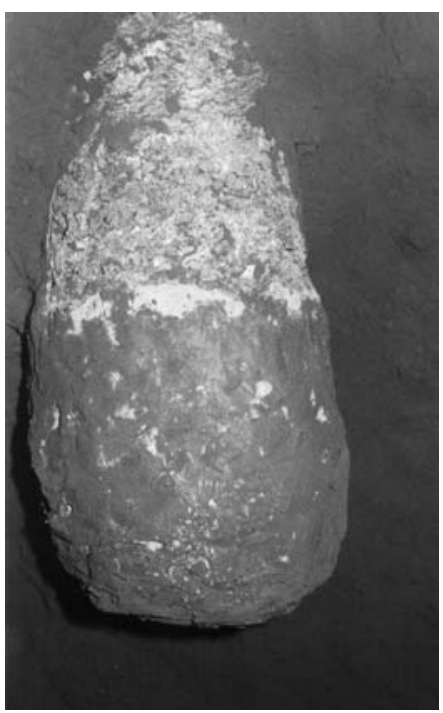

Figura 5.60 - Estaca A9(BS)

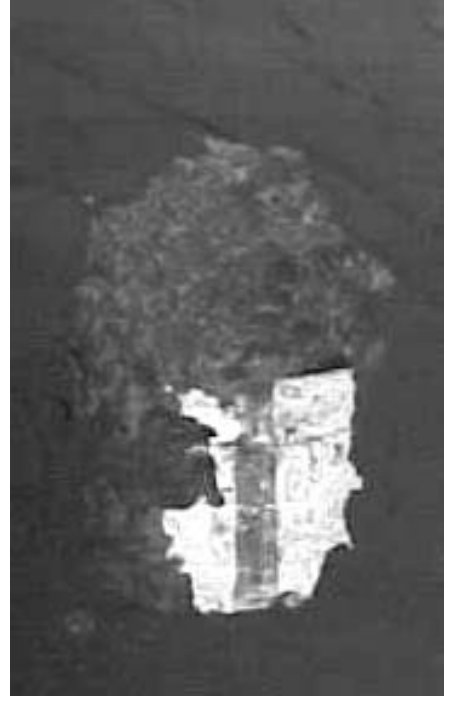

Figura 5.58 - Estaca C4(I)

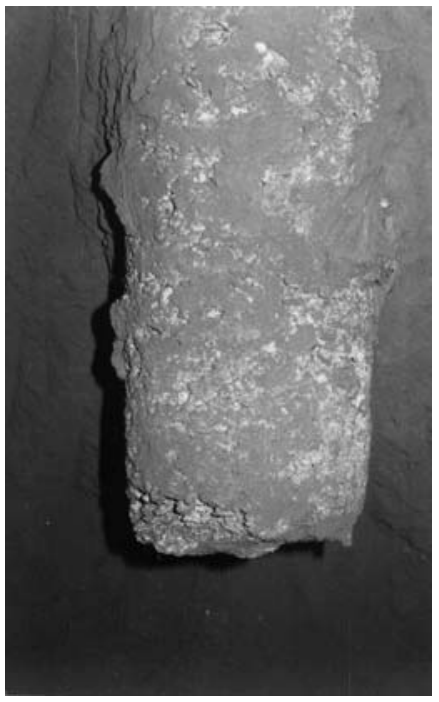

Figura 5.61 - Estaca B8(LC)

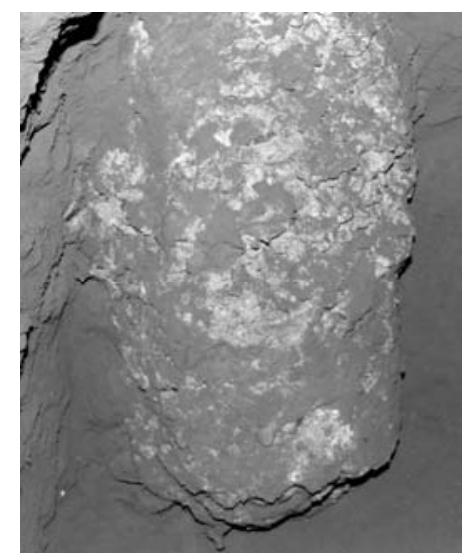

Figura 5.63 - Estaca A12(BA)

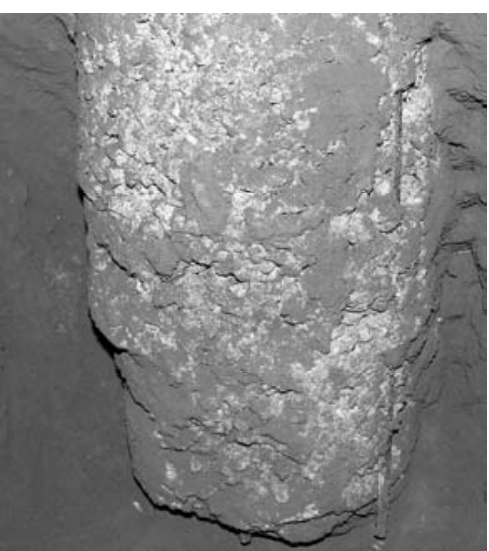

Figura 5.64 - Estaca B11(BA) 


\section{6- Ensaios de laboratório}

Os resultados dos ensaios de determinação do peso específico executados no bloco retirado sob a ponta das estacas A8(SM), A9(BS), B8(LC) e B9(SM) estão mostrados na Figura 5.65.

O gráfico mostra a influência da distância vertical em relação ao peso específico. As primeiras três determinações no bloco sob a ponta da estaca B9(SM) foram feitas na lateral da escavação porque foi revelado, no laboratório, um pedaço da ponta sob o solo proveniente da escavação do poço de inspeção. A Figura 4.38 (Capítulo 4 - Materiais e métodos) ilustra este bloco, com a "calha" onde foram feitas as determinações de peso específico e, ao seu lado, o pedaço da ponta da estaca.

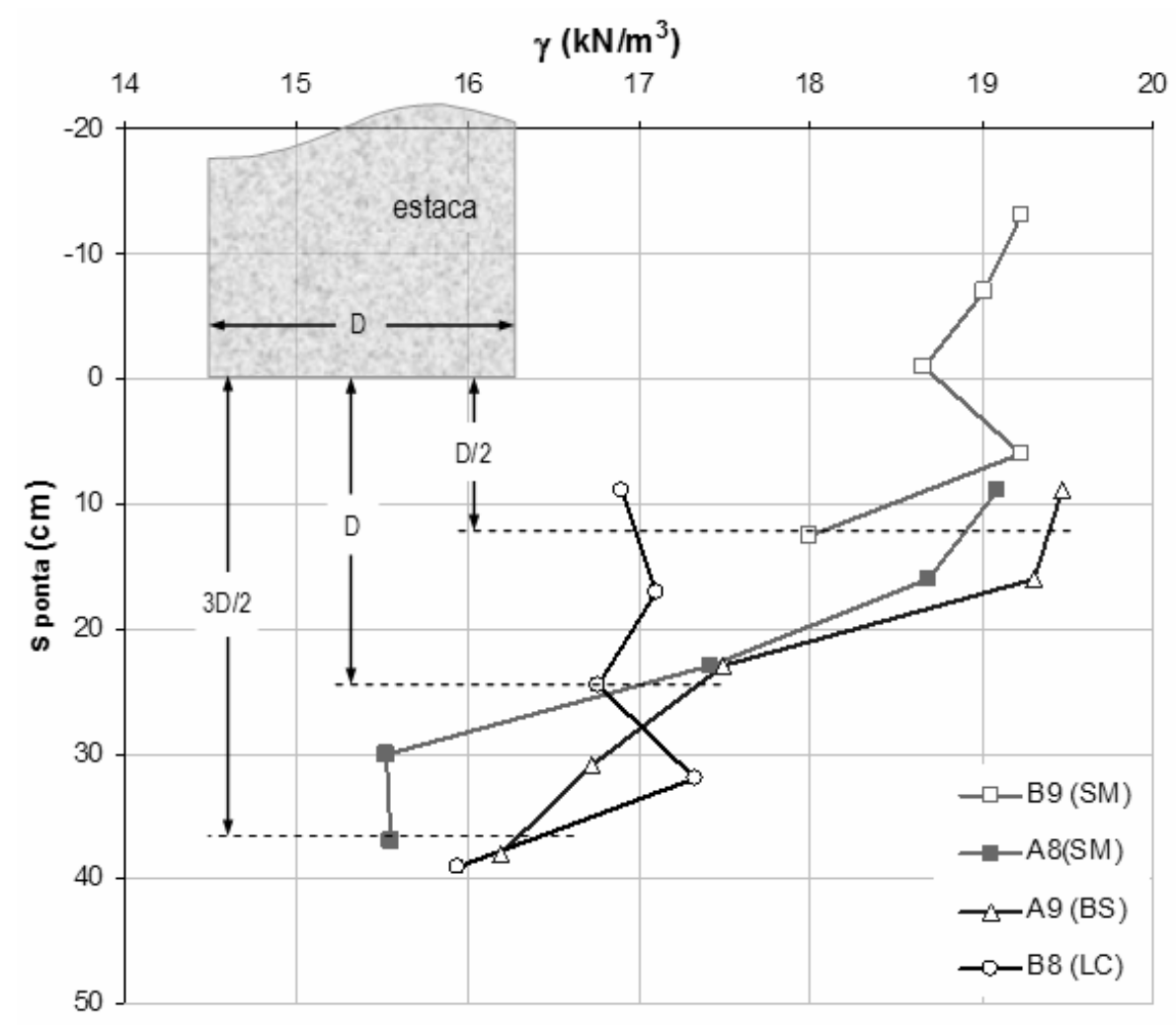

Figura 5.65 - Pesos específicos sob a ponta das estacas da 5a etapa 
Os ensaios triaxiais com sucção controlada do solo não perturbado foram executados em c.ps. talhados a partir dos blocos coletados no poço PE4 (Figura 4.13; Capítulo 4 - Materiais e métodos). Estes ensaios foram executados com as seguintes especificações:
a) $\Psi=0 \mathrm{kPa}, \operatorname{com} \sigma_{3}=60,160$ e $310 \mathrm{kPa}$
b) $\Psi=50 \mathrm{kPa}$, com $\sigma_{3}=50,150$ e $300 \mathrm{kPa}$
c) $\Psi=100 \mathrm{kPa}$, com $\sigma_{3}=100$ e $200 \mathrm{kPa}$

Os resultados obtidos estão ilustrados nas Figuras 5.66 a 5.68.

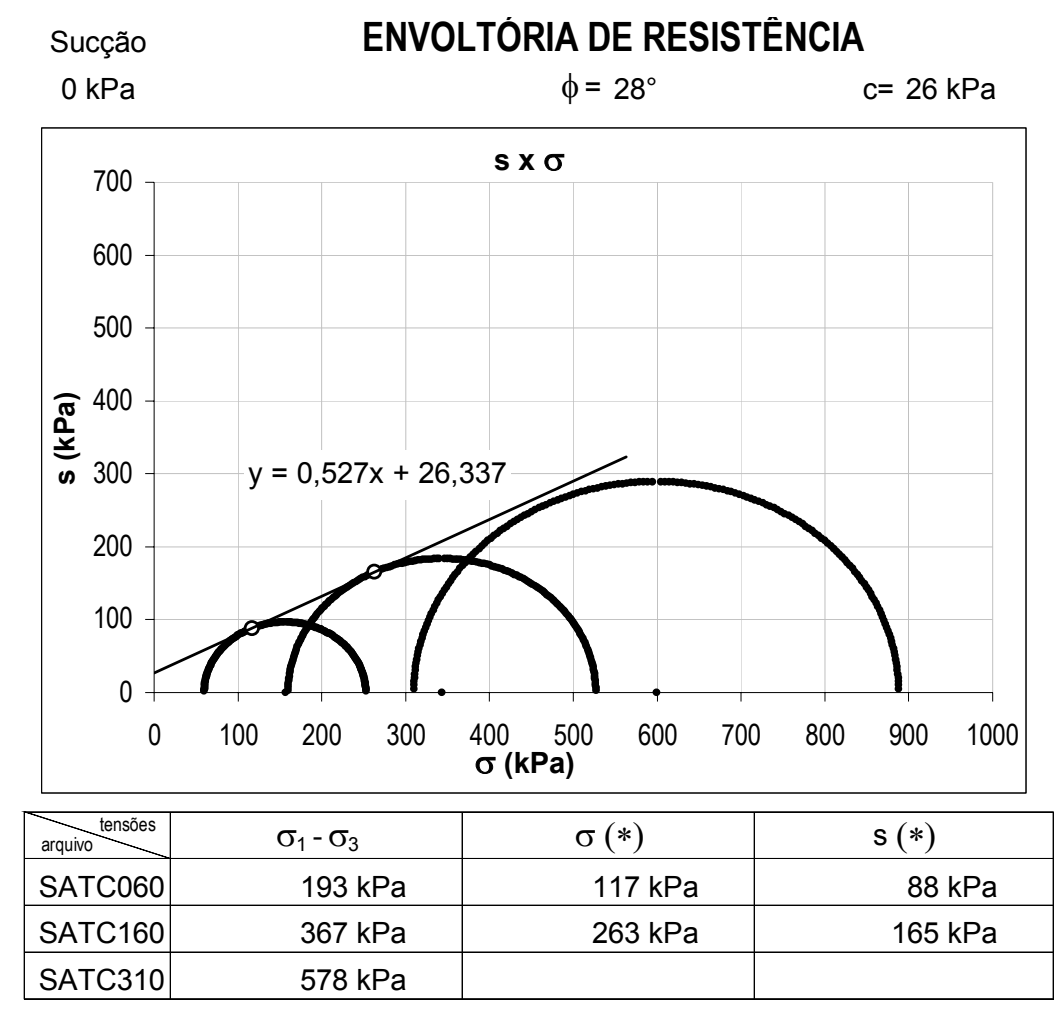

Figura 5.66 - Envoltória do solo com $\psi=0 \mathrm{kPa}$ 


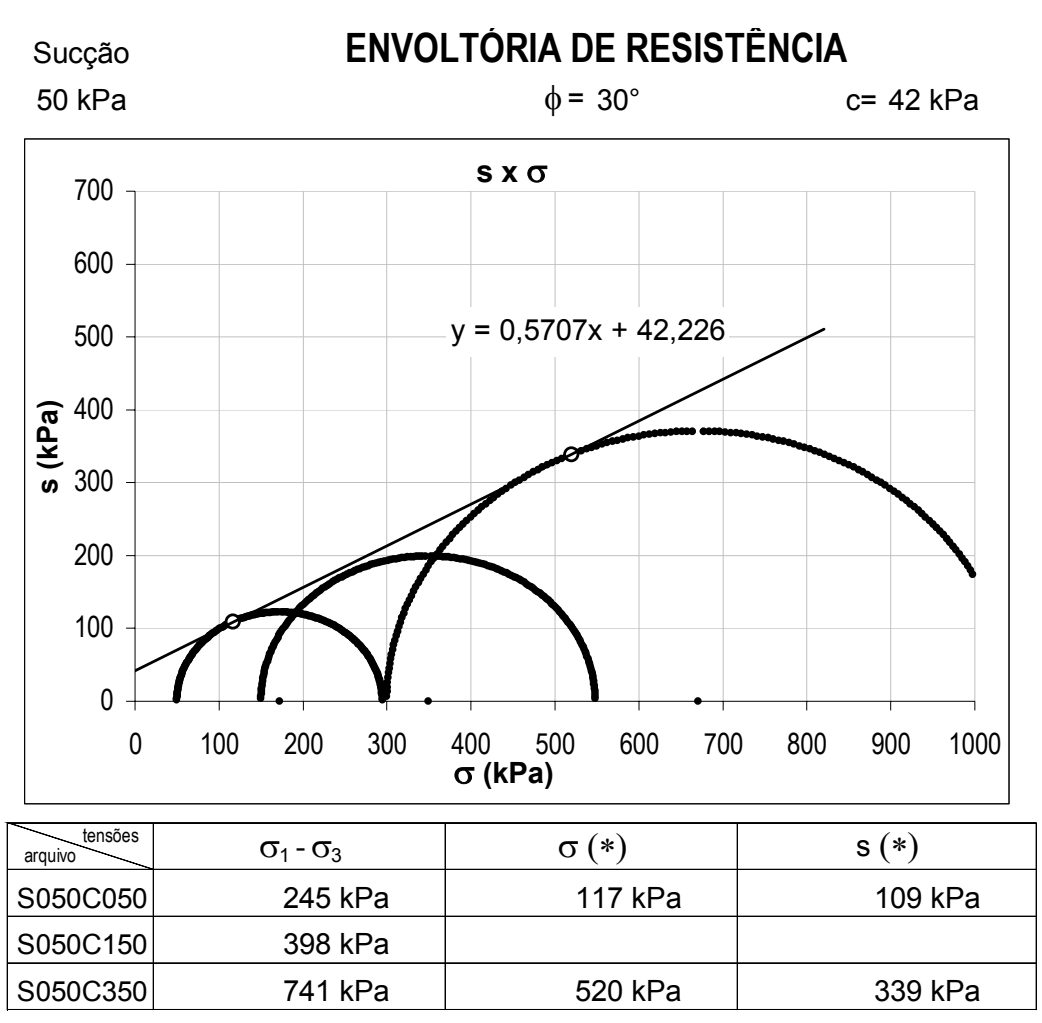

Figura 5.67 - Envoltória do solo com $\psi=50 \mathrm{kPa}$

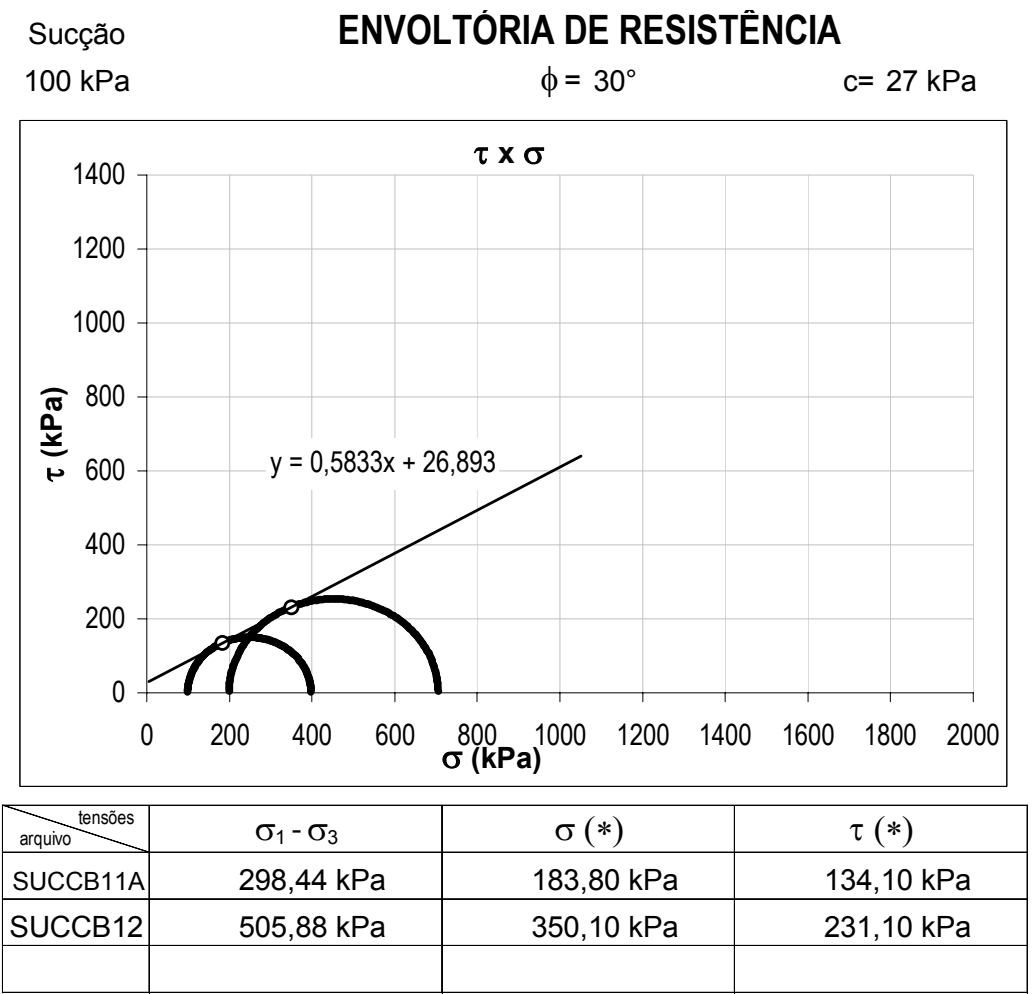

Figura 5.68 - Envoltória do solo com $\psi=100 \mathrm{kPa}$ 
Antes da nova campanha de ensaios triaxiais executados sob as amostras dos blocos coletados sob a ponta das estacas da $5^{\text {a }}$ etapa, foi feita uma investigação através de ensaios de compressão simples, para a verificação da possível influência do preparo da ponta nos parâmetros de resistência do solo. Para tanto, foram talhados três c.ps. a $5 \mathrm{~cm}$ abaixo da ponta da estaca do bloco B9(SM), em diferentes distâncias radiais, de acordo com as possibilidades geométricas do bloco.

Os resultados, em forma de gráficos, estão ilustrados nas Figuras 5.69 a 5.71.

A análise destes resultados mostrou que houve definição da ruptura em todos os casos e que as resistências encontradas foram inversamente proporcionais às distâncias dos c.ps. em relação ao eixo das estacas, indicando a ocorrência de compactação do solo na ponta da estaca.

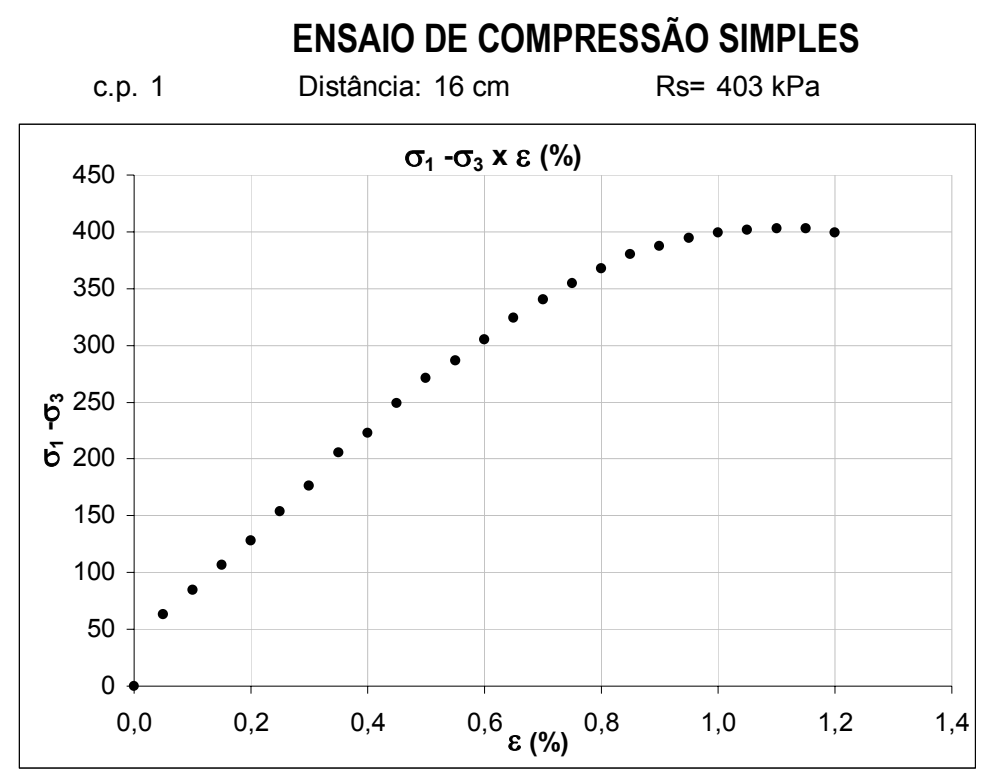

Figura 5.69 - Amostra a $5 \mathrm{~cm}$ abaixo e $16 \mathrm{~cm}$ de distância do eixo da estaca B9(SM) 


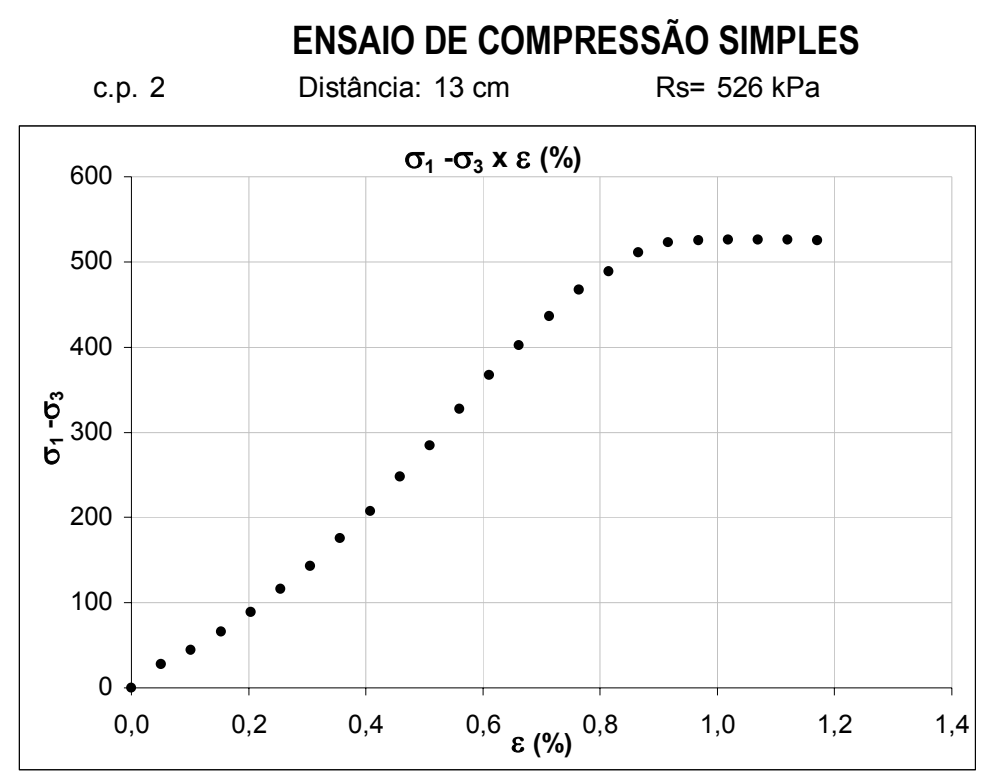

Figura 5.70 - Amostra a $5 \mathrm{~cm}$ abaixo e $13 \mathrm{~cm}$ de distância do eixo da estaca B9(SM)

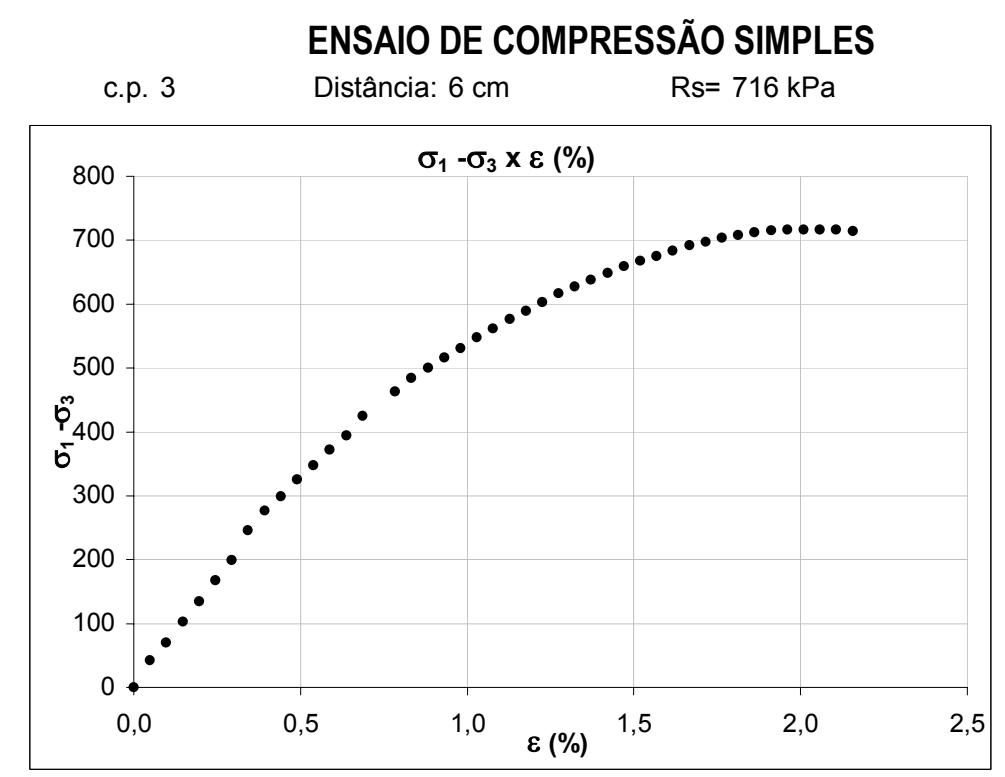

Figura 5.71 - Amostra a $5 \mathrm{~cm}$ abaixo e $6 \mathrm{~cm}$ de distância do eixo da estaca B9(SM)

As resistências à compressão simples obtidas em função da distância do eixo da estaca estão ilustradas na Figura 5.72. 


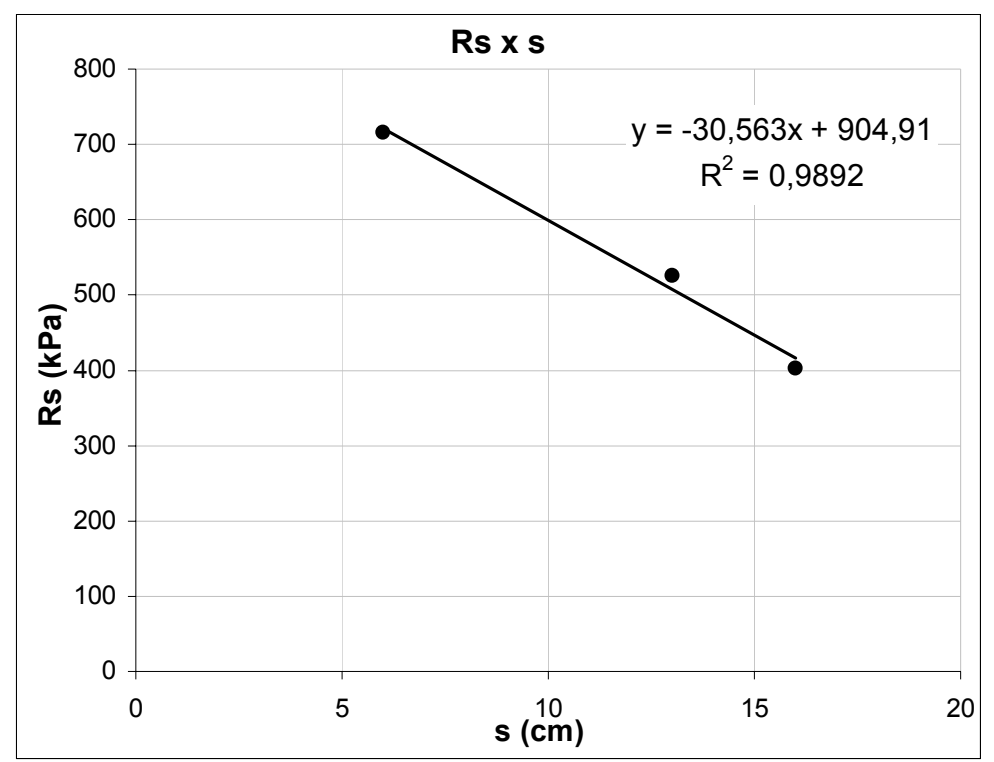

Figura 5.72 - Resistência à compressão simples x distância do eixo da estaca B9(SM)

Foram ensaiados nove c.ps., talhados $10 \mathrm{~cm}$ abaixo da ponta da estaca do bloco A9(BS), em diferentes distâncias radiais, de acordo com as possibilidades geométricas do bloco, para investigar a possível influência da compactação do solo na ponta desta estaca. Os resultados desta campanha de ensaios triaxiais, do tipo CD e drenados ao ar, estão ilustrados nas Figuras 5.73 a 5.75 .

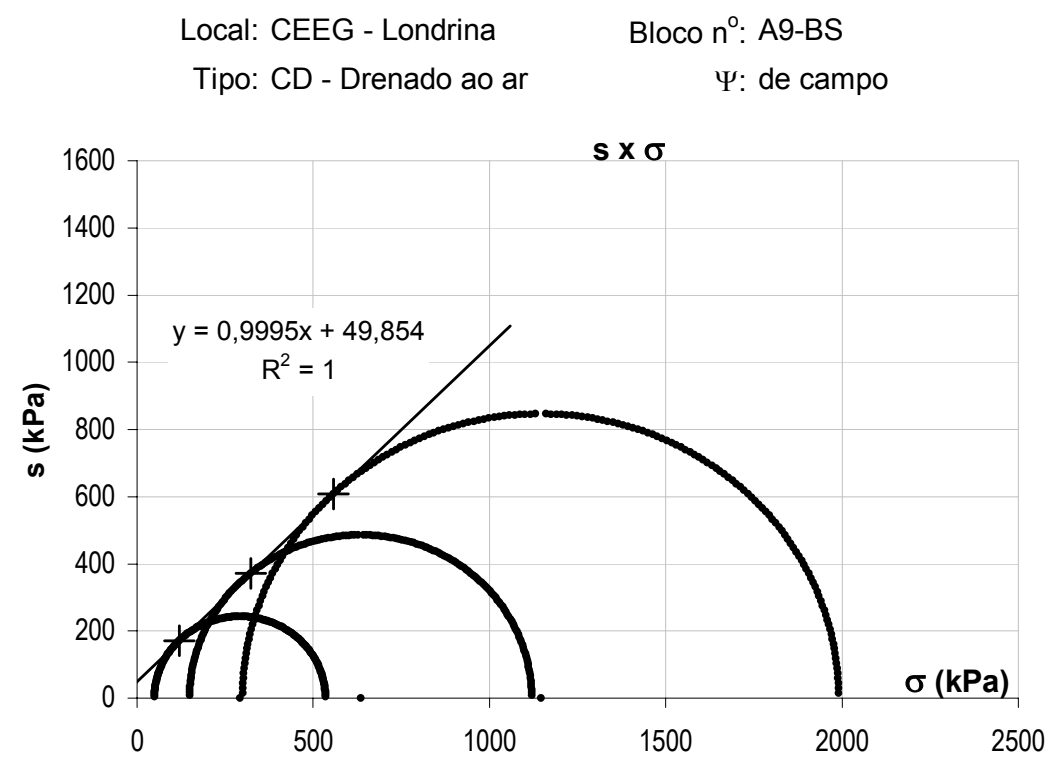

Figura 5.73 - Amostra a $5 \mathrm{~cm}$ abaixo e $20 \mathrm{~cm}$ de distância do eixo da ponta de A9(BS) 


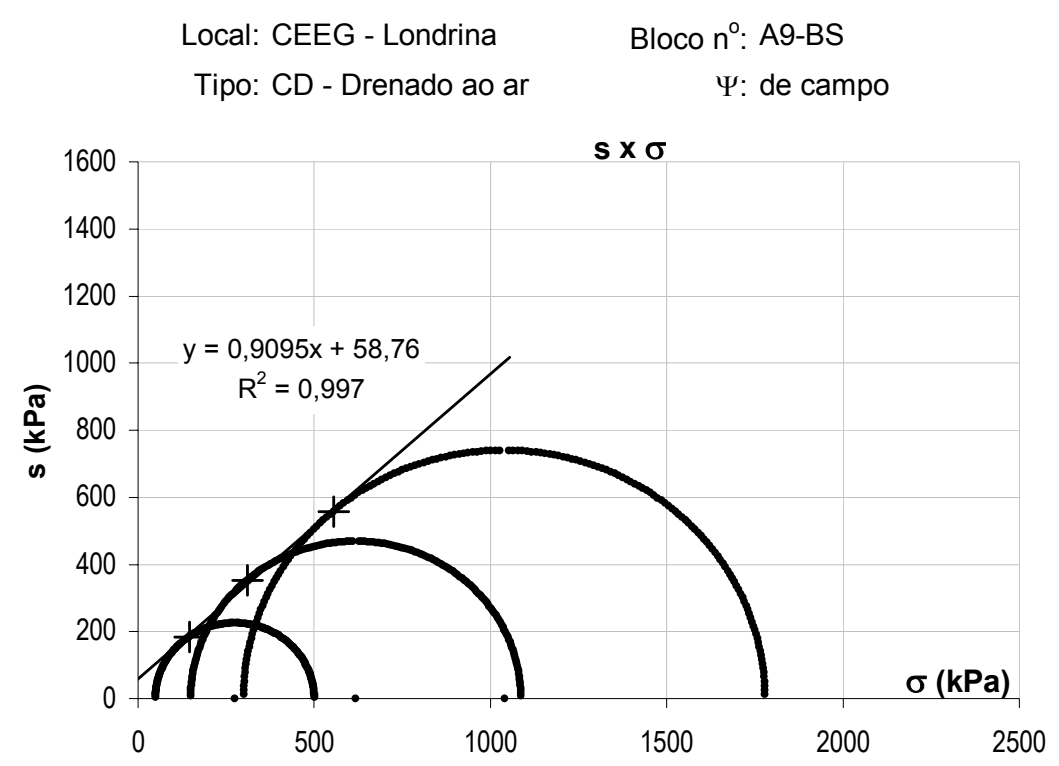

Figura 5.74 - Amostra a $5 \mathrm{~cm}$ abaixo e $13 \mathrm{~cm}$ de distância do eixo da ponta de A9(BS)

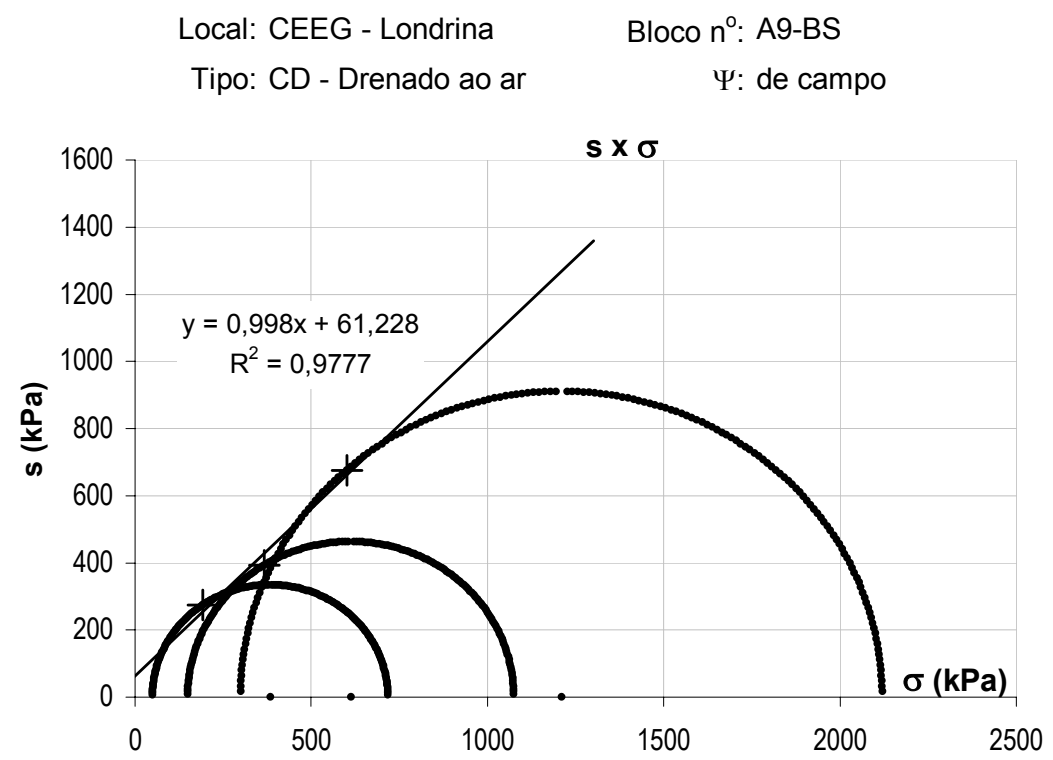

Figura 5.75 - Amostra a $5 \mathrm{~cm}$ abaixo e $8,5 \mathrm{~cm}$ de distância do eixo da ponta de A9(BS)

Os resultados obtidos estão mostrados na Tabela 5.10.

Tabela 5.10 - Resultados dos ensaios triaxiais do tipo CD e drenados ao ar

\begin{tabular}{|r|c|c|c|c|c|c|}
\hline$\sigma_{3}$ tensöe: & $\sigma_{20 \mathrm{~cm}}$ & $\mathrm{~S}_{20 \mathrm{~cm}}$ & $\sigma_{13 \mathrm{~cm}}$ & $\mathrm{~s}_{13 \mathrm{~cm}}$ & $\sigma_{8,5 \mathrm{~cm}}$ & $\mathrm{~S}_{8,5 \mathrm{~cm}}$ \\
\hline $50 \mathrm{kPa}$ & $121 \mathrm{kPa}$ & $172 \mathrm{kPa}$ & $146 \mathrm{kPa}$ & $185 \mathrm{kPa}$ & $192 \mathrm{kPa}$ & $274 \mathrm{kPa}$ \\
\hline $150 \mathrm{kPa}$ & $323 \mathrm{kPa}$ & $372 \mathrm{kPa}$ & $311 \mathrm{kPa}$ & $354 \mathrm{kPa}$ & $368 \mathrm{kPa}$ & $392 \mathrm{kPa}$ \\
\hline $300 \mathrm{kPa}$ & $558 \mathrm{kPa}$ & $609 \mathrm{kPa}$ & $554 \mathrm{kPa}$ & $558 \mathrm{kPa}$ & $601 \mathrm{kPa}$ & $676 \mathrm{kPa}$ \\
\hline$\varphi, \mathrm{c}$ & $\varphi=45^{\circ}$ & $\mathrm{C}=50 \mathrm{kPa}$ & $\varphi=45^{\circ}$ & $\mathrm{C}=59 \mathrm{kPa}$ & $\varphi=44^{\circ}$ & $\mathrm{C}=61 \mathrm{kPa}$ \\
\hline$\gamma, \sigma_{\mathrm{v}}$ & $16,5 \mathrm{kN} / \mathrm{m}^{3}$ & $198 \mathrm{kPa}$ & $16,5 \mathrm{kN} / \mathrm{m}^{3}$ & $198 \mathrm{kPa}$ & $16,5 \mathrm{kN} / \mathrm{m}^{3}$ & $198 \mathrm{kPa}$ \\
\hline $\mathrm{s}_{12 \mathrm{~m}}$ & \multicolumn{2}{|c|}{$\mathrm{s}=248 \mathrm{kPa}$} & \multicolumn{2}{|c|}{$\mathrm{s}=256 \mathrm{kPa}$} & $\mathrm{s}=255 \mathrm{kPa}$ \\
\hline
\end{tabular}


A análise destes resultados mostrou um aumento da resistência inversamente à distância do c.p. até o eixo da estaca. Os critérios utilizados para a definição das envoltórias de resistência foram a limitação das deformações em $15 \%$ e a busca de ajustes, expressos por $\mathrm{R}^{2}$, mais próximos da unidade, com ângulos de atrito coerentes com estes círculos.

\section{7- Especificações teóricas do TI-01}

O funcionamento planejado para o TI-01 compreende, seqüencialmente, a abertura total das lâminas, a expulsão da base, o recolhimento da base e o recolhimento das lâminas. Para isto foi desenvolvido um dispositivo interno no cilindro hidráulico que permitisse o funcionamento nesta seqüência. Desta forma, a abertura das lâminas permite a ancoragem na superfície lateral e a expulsão da base, para reduzir o volume de vazios do solo solto no fundo. O final desta redução pode ser identificado pelo movimento ascensional do equipamento, quando a expulsão da base pode ser interrompida e iniciada o seu recolhimento e das lâminas.

Foram feitos os cálculos da geometria e das forças durante a operação do TI-01, para estabelecer as grandezas envolvidas e as possibilidades e limitações de aplicação do equipamento. Como a força aplicada e a geometria em relação à superfície de contato com o solo são variáveis em função da abertura das lâminas, a pressão de contato também varia e tende para um valor mínimo que representa a limitação na fase final da abertura.

As especificações teóricas, em termos de forças e pressões disponíveis $\times$ abertura das lâminas do TI-01, estão apresentados na Tabela 5.11 e no gráfico da Figura 5.76. 
Tabela 5.11 - Pressões disponíveis $\mathrm{x}$ abertura das lâminas do TI-01

\begin{tabular}{|c|c|c|c|c|c|c|c|}
\hline \multicolumn{2}{|c|}{$\phi_{\text {cil }}=152 \mathrm{~mm}$} & \multicolumn{2}{c|}{$\ell_{\text {braço }}=80 \mathrm{~mm}$} & \multicolumn{2}{c|}{$\mathrm{F}_{\text {cil }(14 \mathrm{MPa})}=255 \mathrm{kN}$} & \multicolumn{2}{c|}{$\mathrm{F}_{\text {cil }(18 \mathrm{MPa})}=328 \mathrm{kN}$} \\
\hline abertura & $\phi(\mathrm{mm})$ & $\mathrm{h}(\mathrm{mm})$ & $\mathrm{A}\left(\mathrm{cm}^{2}\right)$ & $\mathrm{F}_{\text {H min }}$ & $\mathrm{F}_{\text {H máx }}$ & $\sigma_{\text {min }}$ & $\sigma_{\text {máx }}$ \\
\hline 0 & 246 & 0,00 & 0,00 & $0 \mathrm{kN}$ & $0 \mathrm{kN}$ & $0 \mathrm{kPa}$ & $0 \mathrm{kPa}$ \\
\hline 1 & 257 & 10,92 & 88,00 & $18 \mathrm{kN}$ & $23 \mathrm{kN}$ & $1995 \mathrm{kPa}$ & $2565 \mathrm{kPa}$ \\
\hline 2 & 258 & 20,02 & 161,64 & $19 \mathrm{kN}$ & $25 \mathrm{kN}$ & $7053 \mathrm{kPa}$ & $9032 \mathrm{kPa}$ \\
\hline 3 & 259 & 27,72 & 224,24 & $21 \mathrm{kN}$ & $27 \mathrm{kN}$ & $5084 \mathrm{kPa}$ & $6511 \mathrm{kPa}$ \\
\hline 4 & 260 & 34,33 & 278,26 & $22 \mathrm{kN}$ & $29 \mathrm{kN}$ & $4097 \mathrm{kPa}$ & $5247 \mathrm{kPa}$ \\
\hline 5 & 261 & 40,05 & 325,25 & $24 \mathrm{kN}$ & $31 \mathrm{kN}$ & $3505 \mathrm{kPa}$ & $4489 \mathrm{kPa}$ \\
\hline 6 & 266 & 60,10 & 492,79 & $32 \mathrm{kN}$ & $41 \mathrm{kN}$ & $2313 \mathrm{kPa}$ & $2963 \mathrm{kPa}$ \\
\hline 7 & 276 & 80,21 & 670,29 & $48 \mathrm{kN}$ & $62 \mathrm{kN}$ & $1701 \mathrm{kPa}$ & $2178 \mathrm{kPa}$ \\
\hline 8 & 286 & 90,32 & 768,96 & $64 \mathrm{kN}$ & $82 \mathrm{kN}$ & $1483 \mathrm{kPa}$ & $1899 \mathrm{kPa}$ \\
\hline 9 & 296 & 96,42 & 836,04 & $80 \mathrm{kN}$ & $103 \mathrm{kN}$ & $1364 \mathrm{kPa}$ & $1746 \mathrm{kPa}$ \\
\hline 10 & 306 & 100,53 & 887,47 & $96 \mathrm{kN}$ & $123 \mathrm{kN}$ & $1285 \mathrm{kPa}$ & $1645 \mathrm{kPa}$ \\
\hline 11 & 316 & 103,50 & 929,94 & $112 \mathrm{kN}$ & $144 \mathrm{kN}$ & $1226 \mathrm{kPa}$ & $1570 \mathrm{kPa}$ \\
\hline 12 & 326 & 105,75 & 966,77 & $128 \mathrm{kN}$ & $164 \mathrm{kN}$ & $1179 \mathrm{kPa}$ & $1510 \mathrm{kPa}$ \\
\hline 13 & 336 & 107,54 & 1000,03 & $144 \mathrm{kN}$ & $185 \mathrm{kN}$ & $1140 \mathrm{kPa}$ & $1460 \mathrm{kPa}$ \\
\hline 14 & 346 & 108,99 & 1030,63 & $160 \mathrm{kN}$ & $205 \mathrm{kN}$ & $1106 \mathrm{kPa}$ & $1417 \mathrm{kPa}$ \\
\hline 15 & 356 & 110,20 & 1059,38 & $176 \mathrm{kN}$ & $226 \mathrm{kN}$ & $1076 \mathrm{kPa}$ & $1378 \mathrm{kPa}$ \\
\hline 16 & 366 & 111,24 & 1086,85 & $192 \mathrm{kN}$ & $246 \mathrm{kN}$ & $1049 \mathrm{kPa}$ & $1343 \mathrm{kPa}$ \\
\hline 17 & 370 & 111,61 & 1097,48 & $198 \mathrm{kN}$ & $254 \mathrm{kN}$ & $1039 \mathrm{kPa}$ & $1330 \mathrm{kPa}$ \\
\hline
\end{tabular}

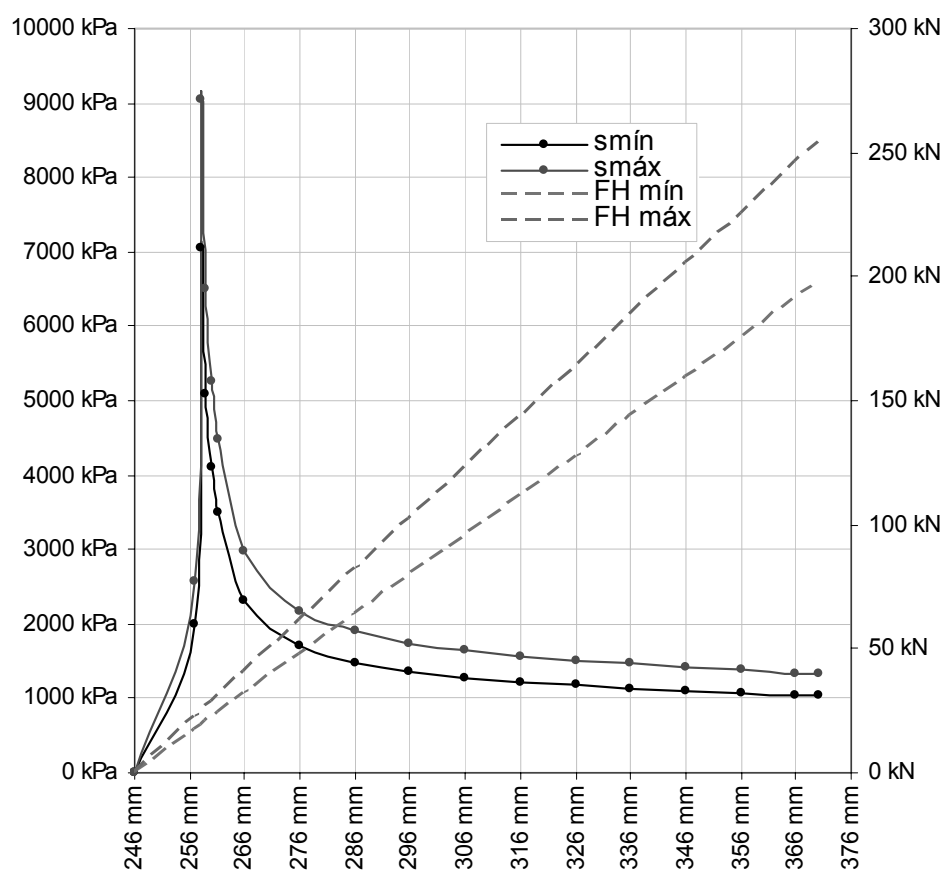

Figura 5.76 - Pressões disponíveis $x$ abertura das lâminas do TI-01

Os resultados mostram que a pressão mínima disponível na parede da escavação é de cerca de $1 \mathrm{MPa}$. A pressão máxima disponível na base foi calculada em 1,1 MPa. 


\section{6- CONCLUSÃO E SUGESTÕES PARA FUTURAS PESQUISAS}

\section{1- Conclusão}

As principais conclusões são:

(a) A variabilidade dos parâmetros geotécnicos do perfil é elevada na superfície, se mantém em torno de $30 \%$ ao longo do horizonte B e tende a diminuir com a profundidade. No entanto, na profundidade da ponta das estacas, o efeito escala se manifesta mais intensamente, especialmente em ensaios feitos em amostras de dimensões reduzidas.

(b) As sondagens de simples reconhecimento com SPT-T podem não caracterizar adequadamente a parte superior do perfil, porque os ensaios são realizados somente a partir de 1 metro de profundidade. Diferentemente do SPT, os procedimentos usuais dos ensaios dos tipos Dynamic Probe (DP), Cone Penetration Test (CPT) e DilatoMeter Test (DMT) conseguem esta caracterização porque realizam os ensaios em intervalos menores de profundidade. Sugere-se que, em casos específicos, seja feito um SPT-T adicional neste primeiro metro, sem prejuízo dos ensaios nas demais profundidades. 
(c) Estacas escavadas com trado mecânico da forma tradicional no perfil estudado não conseguem promover a limpeza eficaz do fundo da escavação, gerando acúmulo de cerca de $30 \mathrm{~cm}$ de detritos. A quase totalidade deste solo solto é de material desagregado e removido pelo trado. Isto pode ser comprovado pela compatibilidade com o volume formado pela geometria não retentiva do trado.

(d) As formas das pontas modificadas das estacas observadas foram coerentes com o processo executivo. As estacas do tipo limpa com caçamba (LC) apresentaram seção homogênea, as do tipo solo melhorado (SM) apresentaram redução de seção, na região de apiloamento do solo, compatível com o diâmetro do soquete empregado, as do tipo "bucha de Strauss" (BS) apresentaram aumento de diâmetro em forma de um bulbo, passando dos $25 \mathrm{~cm}$ nominais para cerca de $30 \mathrm{~cm}$ e as do tipo base alargada (BA) apresentaram ligeiro aumento de diâmetro, na região de atuação do equipamento, para cerca de $28 \mathrm{~cm}$.

(e) A análise dos resultados dos ensaios feitos em amostras do solo abaixo das pontas das estacas dos tipos solo melhorado (SM) e "bucha de Strauss" (BS) mostraram que houve uma densificação, com aumento da resistência.

(f) Com a evolução dos golpes dos ensaios dinâmicos, a resistência lateral no topo das estacas passou por um pico e diminuiu para uma resistência lateral residual, com distribuição de carga para as seções inferiores e a ponta das estacas.

(g) O match representa a similaridade dos pontos de duas curvas (afastamento ou aproximação) e não representa, no caso de estacas escavadas, necessariamente, a realidade física. A evolução do match, associada à direção que está sendo pesquisada, indica a assertividade deste caminho. 
(h) A ruptura ocorreu com pequenas $\mathrm{h}_{\text {queda }}$ do martelo, entre 20 e $60 \mathrm{~cm}$ para os ensaios e 40 e $80 \mathrm{~cm}$ para os reensaios. Sugere-se que seja feita uma campanha inicial de ensaios, uma análise rápida dos resultados e, então, a escolha mais adequada das $\mathrm{h}_{\text {queda }}$ do martelo para os ensaios.

(i) Das estacas ensaiadas estaticamente na condição de pré-inundação, somente a estaca A4 apresentou pequena redução da capacidade de carga. No entanto, deve-se lembrar que essas estacas já haviam passado por ensaio e reensaio dinâmicos e mais um ensaio estático, antes destas PCEs na condição de pré-inundação.

(j) A pré-inundação não provocou redução sensível na capacidade de carga dessas estacas e alterou o teor de umidade do solo superficial, somente até a profundidade de cerca de 6 a 7 metros. A mudança observada se apresentou na forma de um comportamento mais frágil, com menores recalques e uma ruptura brusca.

(k) Todas as estacas com ponta modificada apresentaram aumento da capacidade de carga, fazendo com que a carga admissível da estaca deixe de ser limitada pela carga admissível geotécnica e passe a ser limitada pela carga admissível estrutural. A estaca que apresentou o maior aumento da capacidade de carga foi a do tipo solo melhorado (SM), com aumento médio de $36 \%$ nos ensaios e de $30 \%$ nos reensaios. Dependendo das condições da planta de cargas e do perfil geotécnico, sua utilização pode permitir economia na execução de fundações de pequeno e médio porte, pois permite alguma redução no comprimento das estacas, além de provável redução da quantidade de estacas. 


\section{2- Sugestões para futuras pesquisas}

(a) Sugere-se uma investigação mais detalhada de eventuais tensões residuais em ensaios estáticos e dinâmicos sobre estacas escavadas neste tipo de perfil.

(b) Sugere-se que a técnica de melhoramento da resistência de ponta com o uso do equipamento denominado TI-01 seja melhorada, com a inclusão de instrumento de monitoramento da força aplicada, da abertura das lâminas e do deslocamento da base, para permitir o estabelecimento de um modelo teórico correspondente. Além disso, deve permitir o seu uso em fundações de grandes dimensões, inclusive abaixo do nível freático, como as estacas escavadas com auxílio da lama bentonítica. Para isto, deverão passar por readequações relativamente simples de serem implementadas. 


\section{7- REFERÊNCIAS BIBLIOGRÁFICAS}

ALBUQUERQUE, P.R.; MASSAD, F.; CARVALHO, D.; FERREIRA, M.A.M. (2001) Comportamento à compressão de estacas escavadas, hélide contínua e hélice tipo Ômega, em solo residual de diabásio. Unicamp, Campinas, Brasil, 198p.

AL-AWQUATI, Z.; VESIC', A.S. (1972) Effect of lateral pressure on penetration resistance and bearing capacity of piles. ASCE, Houston, EUA.

ARAK, M. S. (1997) Aspectos relativos às propriedades dos solos porosos colapsíveis do Distrito Federal. Universidade de Brasília, Departamento de Engenharia Civil, Dissertação de mestrado, publicação G.DM-040/97, Brasília, Brasil, 121p.

ASSOCIAÇÃO BRASILEIRA DE EMPRESAS DE ENGENHARIA DE FUNDAÇÕES E GEOTECNIA (1999) Manual de especificações de produtos e procedimentos ABEF. ABEF, São Paulo, Brasil, 2a edição, 282p.

ASSOCIAÇÃO BRASILEIRA DE GEOLOGIA DE ENGENHARIA (1996) Ensaios de permeabilidade em solos - Orientações para a sua execução no campo. ABGE, Boletim n⿳ํㅡㄴ $3^{\text {a }}$ edição, São Paulo, Brasil, 34p.

ASSOCIAÇÃO BRASILEIRA DE NORMAS TÉCNICAS (1984) NBR-7181 - SoloAnálise granulométrica. ABNT, Rio de Janeiro, Brasil, 13p.

ASSOCIAÇÃO BRASILEIRA DE NORMAS TÉCNICAS (1986) NBR-7182 - Solo Ensaio de compactação. ABNT, Rio de Janeiro, Brasil, 10 p.

ASSOCIAÇÃO BRASILEIRA DE NORMAS TÉCNICAS (2003) NBR-8522 - Concreto Determinação dos módulos estáticos de elasticidade e de deformação e da curva tensãodeformação. ABNT, Rio de Janeiro, Brasil, 9p.

ASSOCIAÇÃO BRASILEIRA DE NORMAS TÉCNICAS (1991) MB-3406 - Solo - ensaio de penetração de cone in situ (CPT) - método de ensaio. ABNT, Rio de Janeiro, Brasil, 10p.

ASSOCIAÇÃO BRASILEIRA DE NORMAS TÉCNICAS (1991) MB-3472 - Estacas Prova de carga estática. ABNT, Rio de Janeiro, Brasil, 4p.

ASSOCIAÇÃO BRASILEIRA DE NORMAS TÉCNICAS (1996) NBR-6122 - Projeto e execução de fundação. ABNT, Rio de Janeiro, Brasil, 33p. 
ASSOCIAÇÃO BRASILEIRA DE NORMAS TÉCNICAS (1997) NBR-6484 - Solos sondagens de simples reconhecimento com SPT - método de ensaio. ABNT, Rio de Janeiro, Brasil, 16p.

AOKI, N.; VELLOSO, D.A. (1975) An approximate method to estimate the bearing capacity of piles. In: V PAN AMERICAN CONFERENCE ON SOIL MECHANICS AND FOUNDATION ENGINEERING, Buenos Aires, Argentina, Vol. 1, p.367-376.

AOKI, N. (1997) Determinação da capacidade de carga última de estaca cravada em ensaio de carregamento dinâmico de energia crescente. EESC/USP, Tese de doutoramento, São Carlos/SP, Brasil, 111p.

BALIGH, M.M. (1985) Strain path method. JOURNAL OF GEOTECHNICAL ENGINEERING, ASCE, Vol. III, nº 9, p. 1108-1136.

BASE FORTE (2004) Catálogo eletrônico do biocatalisador EMC ${ }^{2}$. Base Forte Impermeabilizantes de Solo Ltda., Curitiba, Brasil, 6 p.

BAUER (1997) Fabricante de equipamentos para fundações - Catálogo de equipamentos, Germany, $56 \mathrm{p}$.

BERETTA ALFREDO (1999) Fabricante de equipamentos para fundações - Catálogo de equipamentos, Itália, $8 \mathrm{p}$.

BISHOP, R.F.; HILL, R.; MOTT, N.F. (1945) Theory of indentation and hardness tests. In: Physical Society of London, Vol. 57, part 3, nº 321, p. 147-159.

BOLOGNESI, A.J.L.; MORETTO, O. (1973) Stage grouting preloading of large piles on sand. VII ICSMFE, Moscow, p. 19-25.

BOTTIAU, M.; VAN IMPE, P.O.; MEYUS, I.A.; RUSSO, G. (1998) Load testing at Feluy test site. In: DEEP FOUNDATIONS ON BORED AND AUGER PILES, Ghent, Belgium, p.187-199.

BRANCO C. J. M. C.; TEIXEIRA R. S. S. (2006) Campo experimental da UEL. In: XI CONGRESSO BRASILEIRO DE MECÂNICA DOS SOLOS E ENGENHARIA DE FUNDAÇÕES, Brasília, Brasil, Volume referente ao Workshop - Campos experimentais de fundações, Cap. 3.9, Curitiba, Brasil, p.63-70.

BROMS (1985) Expander bodies - A new concept for underpinning of structures. In: ELEVENTH INTERNATIONAL CONFERENCE ON SOIL MECHANICS AND FOUNDATION ENGINEERING, San Francisco, USA, p.1531-1534.

BUSTAMENTE, M.; GIANESELLI, L. (1998) Installation parameters and capacity of screwed piles. In: DEEP FOUNDATIONS ON BORED AND AUGER PILES, Ghent, Belgium, p. 95-108.

CASAGRANDE (1999) Fabricante de equipamentos para fundações - Catálogo de equipamentos, Itália, $14 \mathrm{p}$.

CEPOLINA, M. (2000) Definição. Estacas raiz: Projeto, execução e controle, Falconi et al. (eds.), ABMS, São Paulo, Brasil, Cap. 2, p. 11-17. 
CINTRA, J. C. A. (1998) Fundações em solos colapsíveis. Editora Rima, São Carlos, SP, $106 \mathrm{p}$.

CINTRA, J. C. A.; AOKI, N. (1999) Carga admissível em fundações profundas. USP/SC, Projeto Reenge, São Carlos, SP, 61p.

CINTRA, J. C. A.; MACACARI, F. M., AOKI, N., VILAR, O. M. (2005) Variação da capacidade de carga com a sucção matricial e com a profundidade em provas de carga sobre placa em solo colapsível. Revista Solos e Rochas, v. 28, no 1, p. 21-29.

CORRÊA, R.S. (1988) Previsão da carga de ruptura de estacas raiz a partir de sondagens de simples reconhecimento. EPUSP, Dissertação de mestrado, São Paulo, Brasil, 155p.

COSTA NUNES, A. J. \& DRINGENBERG, G. E. (1984) Increase in the bearing capacity of piles by soil precompression through the use of grouting. Colloque International Reinforcement in Place des Sols et des Roches, Paris, France.

COSTA NUNES, A. J. (1992) Estacas injetadas - Relato geral. I SEMINÁRIO DE ENGENHARIA DE FUNDAÇÕES ESPECIAIS, São Paulo, Brasil.

COZZOLINO, V. M. N.; NOGAMI, J. S. (1993) Classificação Geotécnica MCT para Solos Tropicai. Revista Solos e Rochas, ABMS/ ABGE, Vol. 16, nº 2, p 77-91.

DATTA, M. (1982) Pore water pressure development during pile driving and its influence on driving resistance. In: CONFERENCE ON BEHAVIOUR OF OFFSHORE STRUCTURES, BOSS, Houston, Vol. 2, p. 295-304.

DÉCOURT, L.; QUARESMA, A.R. (1978) Capacidade de carga de estacas a partir de valores de SPT. In: VI CONGRESSO BRASILEIRO DE MECÂNICA DOS SOLOS E ENGENHARIA DE FUNDAÇÕES. Rio de Janeiro/RJ, Brasil, Vol. 1, p.45-54.

DÉCOURT, L.; QUARESMA FILHO, A. (1996) Estabelecimento das curvas carga-recalque de fundações através de provas de carga em mini placa. In: III SEMINÁRIO DE ENGENHARIA DE FUNDAÇÕES ESPECIAIS, São Paulo, Brasil, V.1, p.225-236.

DÉCOURT, L. (1996) A ruptura de fundações com base no conceito de rigidez. In: III SEMINÁRIO DE ENGENHARIA DE FUNDAÇÕES ESPECIAIS, São Paulo, Brasil, V.1, p.215-224.

DÉCOURT, L. (1996) Análise e Projeto de Fundações Profundas: Estacas. Fundações: Teoria e Prática, Hachich et al. (eds.), Ed. Pini Ltda., São Paulo, Cap. 8.1, p. 265-301.

DÉCOURT, L.; CINTRA, J.C.A. (1996) Análise e projeto de fundações profundas. Fundações: Teoria e Prática, Hachich et al. (eds.), Ed. Pini Ltda., São Paulo, Brasil, Cap. 8.1, p. 275-276.

DE BEER, E. (1963) The scale effect in transportation of the results of deep soundings tests on the ultimate bearing capacity of piles and caissons. GEOTECHNIQUE, Vol. 13, $\mathrm{n}^{\mathrm{o}} 1$.

EVERTS, H.J.; LUGER, H.J. (1998) Dutch national codes for pile design. In: DEEP FOUNDATIONS ON BORED AND AUGER PILES, Ghent, Belgium, p.243-266. 
FERNAL, FÁBIO; SILVA, TÁSSIO BARBOSA; MIGUEL M. G.; BELINCANTA, A (2003) Provas de carga em estacas escavadas com trado manual, em solo colapsível de Londrina/PR. In: IV ENCONTRO TECNOLÓGICO DE ENGENHARIA E ARQUITETURA DE MARINGÁ, anais em CD, Maringá, Brasil, p.388-396.

FINDLAY, J.D.; BROOKS, N.J.; MURE, N.J.; HERON, W (1998) Design of axially loaded piles - United Kingdom practice. In: DEEP FOUNDATIONS ON BORED AND AUGER PILES, Ghent, Belgium, p.353-376.

FRANKE, E. (1984) New developments in german standards for the determination of pile bearing behaviour. In: II SEMINAR PILE FOUNDATIONS, Singapore, p.1-29.

FREDLUND, D.G.; RAHARDO, H. (1993) Soil mechanics for unsatured soils. JOHN WILEY \& SONS, New York, EUA, 517p.

GEOFORUM (2002) http://www.geoforum.com/info/pileinfo/index.asp (maio/2002).

GWIDZDATA, K. (1998) Polish design methods for single axially loaded piles. In: DEEP FOUNDATIONS ON BORED AND AUGER PILES, Ghent, Belgium, p.291-306.

HOLEYMAN, A. (1997) Pile dynamic testing, driving formulae, monitoring and quality control: Background for discussion. In: DESIGN OF AXIALLY LOADED PILES EUROPEAN PRATICE, Brussels, Belgium, pp.47-53.

KERISEL, L. (1964) Deep foundations basic experimental facts. In: INTERNATIONAL CONFERENCE ON PILING AND DEEP FOUNDATIONS, Ciudad del Mexico, Mexico, p.15-44.

KORECK, W. (1978) Small diameter bored injection piles. GROUND ENGINEERING. Vol. $11, \mathrm{n}^{\mathrm{o}} 4$, p. 14-16, 18-20.

KOUNDOU, M.; NISHYAMA, S.; OKUMURA, F. (1998) Effects of repeated stress on soil behaviour at cast-in-place pile toe. In: DEEP FOUNDATIONS ON BORED AND AUGER PILES, Ghent, Belgium, p. 391-397.

KRAFT JR., L.M. (1991) Performance of axially loaded pipe piles in sand. JOURNAL OF GEOTECHNICAL ENGINEERING, ASCE, Vol.117, nº 2, p. 272-296.

LEHANE, B.M. (1998) Design of axially loaded piles - Irish practice. In: DEEP FOUNDATIONS ON BORED AND AUGER PILES, Ghent, Belgium, p.203-218.

LEONARDS, G.A., LOVELL, D. (1979) Interpretation of load tests on high-capacity driven piles. AMERICAN SOCIETY FOR TESTING MATERIALS, p.388-415.

LIZZI, F. (1976) Pieu de foundation à cellule de précharge. Constrution, no 6, Paris, France.

LIZZI, F. (1988) The load bearing capacity of bored piles, a problem not yet satisfactorily solved - some propoals. In: DEEP FOUNDATIONS ON BORED AND AUGER PILES, Ghent, Belgium, p.443-449.

LOPES, F.F. (2002) Avaliação do comportamento colapsível da camada de solo superficial da região de Londrina/ PR. UEL. Trabalho de Conclusão de Curso, Londrina, Brasil, 114p. 
MANDOLINI, A. (1998) Design of axially loaded piles - Italian practice. In: DEEP FOUNDATIONS ON BORED AND AUGER PILES, Ghent, Belgium, p.219-242.

MANOLIU, I. (1998) Design of axially loaded piles - Romanian practice. In: DEEP FOUNDATIONS ON BORED AND AUGER PILES, Ghent, Belgium, p.307-320.

MASSAARSCH, K. R.; TANCRÉ, E.; BRIEKE, W. (1988) Displacement auger piles with compacted base. In: DEEP FOUNDATIONS ON BORED AND AUGER PILES, Ghent, Belgium, p. 333-342.

METS, M. (1998) The bearing capacity of a single pile - Experience in Estonia. In: DEEP FOUNDATIONS ON BORED AND AUGER PILES, Ghent, Belgium, p.115-132.

MEYERHOF, G. G.; MURDOCK, L. J. (1951) An investigation of the bearing capacity of some bored and driven piles in London clay. GEOTÉCHNIQUE, V.3, p.262-267.

MEYERHOF, G. G. (1959) Compaction of sands and bearing capacity of piles. JOURNAL OF THE GEOTECHINICAL ENGINEERING DIVISION, V.85, nํㅗㄴ SM6, p.1-59.

MIGUEL M. G.; BRANCO C. J. M. C.; TEIXEIRA R. S. ; BELINCANTA, A (2003) Comportamento de estacas escavadas com trado manual, em solo colapsível de Londrina/PR. In: I ENCONTRO GEOTÉCNICO DO TERCEIRO PLANALTO PARANAENSE, anais em CD, Maringá, Brasil, 17p.

MORIMOTO, S. (1982) Parâmetros geotécnicos de solos de Londrina. In: VII CONGRESSO BRASILEIRO DE MECÂNICA DOS SOLOS E ENGENHARIA DE FUNDAÇÕES, Olinda, Brasil,

PADILHA, A. C. C. (2004) Determinação da curva característica de sucção do solo argilosiltoso laterítico de Londrina/PR. TCC apresentado para aprovação final no curso de Engenharia Civil da UEL, dez/2004, 63p.

PEIXOTO, R.J.; FEITOSA, J.H.P.; GITIRANA Jr, G.F.N.; CUNHA, R.P.E.; CARVALHO, J.C. (2001) Superfície de estado do solo poroso colapsível do Distrito Federal (Brasil). $4^{\underline{0}}$ SIMPÓSIO BRASILEIRO DE SOLOS NÃO SATURADOS, Porto Alegre, Brasil, p.93.

ROCHA, G. C; BARROS, O.N.F.; GUIMARÃES, M.F. (1991) Distribuição espacial e características dos solos do campus da Universidade Estadual de Londrina, PR. UEL, Revista Semina, Londrina, Brasil, Vol. 12(1), p. 21-25

RODRIGUES, J. (1998) Grauteamento químico. Revista Recuperar, Vol. 23, ano 5, maio/junho, p.4-13.

SAEZ, J.L. (1996) Estacas escavadas com lama bentonítica . Fundações: Teoria e Prática, Hachich et al. (eds.), Ed. Pini Ltda., São Paulo, Cap. 9.1.4, p.348-360.

SALIONI, C. (1985) Capacidade de carga de estacas injetadas. I SEMINÁRIO DE FUNDAÇÕES ESPECIAIS, São Paulo, Brasil, Vol. 1, p.13-27.

SALGADO, R.; MITCHEL, J.K., JAMIOKOLSKI, M. (1997) Cavity expansion and penetration resistance in sand. In: JOURNAL OF GEOTECHNICAL AND GEOENVIROMENTAL ENGINEERING, ASCE, Vol. 2, nํ 4, p.344-354. 
SCHRAM SIMONSEN; A., ATHANASIU, C. (1998) Design of axially loaded piles Norwegian practice. In: DEEP FOUNDATIONS ON BORED AND AUGER PILES, Ghent, Belgium, p.267-290.

SELlGREN, E; HELLMAN, L.; SKOGBERG, B. (1985) Expander piling - A careful foundation and underpinning method. In: ELEVENTH INTERNATIONAL CONFERENCE ON SOIL MECHANICS AND FOUNDATION ENGINEERING, San Francisco, USA, p.1207-1030.

SILVA, M. F. (2001) Estudo do efeito de escala na resistência de ponta de estacas em solos granulares. COPPE/UFRJ, Dissertação de mestrado, Rio de Janeiro, Brasil, 155p.

SILVA, P. E. C. A. (1983) Hidrodynamic expansive cell- a new way to perform loading tests. Publicação independente do autor, Belo Horizonte, Brasil, 106 p.

SKOV, R. (1998) Pile foundation - Danish design methods and piling practice. In: DEEP FOUNDATIONS ON BORED AND AUGER PILES, Ghent, Belgium, p.101-114.

SLIWINSKI, Z.J. (1979) Conditions for effective end bearing of bored, cast in situ piles. RECENT DEVELOPMENTS IN THE DESIGN AND CONSTRUCTION OF PILES ICE, London, United Kingdom, p.73-80.

SMITH, E.A.L. (1960) Pile driving analysis by the wave equation. JOURNAL OF SOIL MECHANICS AND FOUNDATION DIVISION, ASCE, Vol. 86, p. 35-61.

SODRÉ, D.J.R. (1996) Estaca raiz (método executivo e capacidade de carga). EESC/USP, Monografia geotécnica n⿳⺈ 7, São Carlos, Brasil, 94p.

SVENSSON, L.; OLSSON, C.; GRÄVARE, C.J. (1998) Design of axially loaded piles Swedish practice. In: DEEP FOUNDATIONS ON BORED AND AUGER PILES, Ghent, Belgium, p.337-342.

SWEDISH GEOTECHNICAL INSTITUTE (1985) Report of the ISSMSFE technical committee on penetration testing of soils - TC16 with reference test procedures. SGI, Sweden.

TAROZZO, H.; GRANDIS, I. (2000) Seqüência executiva. Estacas Raiz: Projeto, execução e controle, Falconi et al. (eds.), ABMS, São Paulo, Brasil, Cap. 3, p.18-28.

TEJCHMAN, A.; GWIZDALA, K. (1988) Comparative analisys of bearing capacity of large diameter bored pile. In: DEEP FOUNDATIONS ON BORED AND AUGER PILES, Ghent, Belgium, p.553-557.

TEPARAKSA, W. (1992) Behaviour of base-grouted bored piles in Bangkok subsoils. In: PILING: EUROPEAN AND WORLDWIDE TRENDS, London, UK, p.296-301.

TERZAGHI, K. (1942) Discussion of pile driving formulas. Proc. ASCE, 68 (2), p. 311-323.

TERZAGHI, K. (1943) Theoretical soil mechanics. JOHN WILEY \& SONS, New York, USA, 510p. 
TOMLINSON, M. J. (1977) Pile design and construction practice, VIEWPOINT PUBLICATIONS, London, UK, 413p.

VAN DER VEEN, C. (1953) The bearing capacity of a pile. In: X INTERNATIONAL CONFERENCE ON SOIL MECHANICS FOUNDATION ENGINEERING, 3., Zurich, v.2, p.84-90.

VAN IMPE, W. F. (1991) Deformations of deep foundations. In: X INTERNATIONAL CONFERENCE ON SOIL MECHANICS AND FOUNDATION ENGINEERING, Florence, Italy, p.1031-1061.

VAN IMPE, W. F. (1997) Influence of screw pile installation on the stress state in the soil. In: ERTC3 SEMINAR - DESIGN OF AXIALLY LOADED PILES EUROPEAN PRATICE, Brussels, Belgium, p.3-19.

VAN IMPE, W. F.; BROECK, M. V. D; THOOFT, K. (1988) End and shaft bearing capacity of piles evaluated separately out of static pile loading test results. In: DEEP FOUNDATIONS ON BORED AND AUGER PILES, Ghent, Belgium, p.489-497.

VAN IMPE, W. F.; PEIFFER, H. (1997) Influence of screw pile installation on the stress state in the soil. In: ERTC3 SEMINAR - DESIGN OF AXIALLY LOADED PILES EUROPEAN PRATICE, Brussels, Belgium, p.3-19.

VAN WEELE, A. F. (1957) A method of separating the bearing capacity of a test pile into skin-friction and point-resistance. In: IV INTERNATIONAL CONFERENCE ON SOIL MECHANICS AND FOUNDATION ENGINEERING, London, UK, p.76-80.

VAN WEELE, A. F. (1988) Cast-in-situ piles - Installation methods, soil disturbance and resulting pile behaviour. In: IST INTERNATIONAL GEOTECHNICAL SEMINAR ON DEEP FOUNDATIONS ON BORED AND AUGER PILES, Ghent, Netherlands, p.219-226.

VARGAS, M. (1951) Resistência e compressibilidade de argilas residuais. USP/SP, tese apresentada à Escola Politécnica da USP para concorrer à cadeira de Mecânica dos Solos e Fundações, São Paulo, Brasil, p.

VARGAS, M. (1993) Solos porosos e colapsíveis. Aula inaugural de 1992, EESC/USP, São Carlos, Brasil, 40p.

VESIC',A.V . (1975) Principles of foundation design. Soil mechanics series $\mathrm{n}^{\mathrm{0}}$ 38, Lectures 1 and 2, Duke Universtity School of Engineering, Durham, North Carolina, EUA, 103p.

VESSARO, P.; BRANCO, C. J. M. C.; CINTRA, J. C. A.; AOKI, N. (2004) Provas de carga dinâmica em estacas escavadas com trado mecânico. SEFE V, São Paulo, p. 431-440.

WELTMAN, A. (1981) A review of micro pie types. GROUND ENGINEERING. Vol. 14, $\mathrm{n}^{\mathrm{o}}$ 4, p. 43-49.

WHITAKER, T; COOKE, R.W. (1965) Bored piles with enlarged bases in London clay. In: VI INTERNATIONAL CONFERENCE ON SOIL MECHANICS AND FOUNDATION ENGINEERING, Canadá, p.342-346. 
YEATS, J.A.; O'RIORDAN, N.J. (1989) The design and construction of large daimeter base grouted piles in Thanet Sand at Blackwall Yard, London. In: INTERNATIONAL CONFERENCE ON SOIL MECHANICS AND FOUNDATION ENGINEERING, San Francisco, EUA, p. 455-461 